\title{
Onordon
}

\section{Miljøeffektiv teknologi eller miljøteknologi i de nordiske lande}

En undersøgelse af de nordiske landes aktiviteter på området i årene 2004-2011 

4 norden 



\section{Miljøeffektiv teknologi eller miljøteknologi i de nordiske lande}

En unders $\varnothing$ gelse af de nordiske landes aktiviteter på området i årene 2004-2011

Karsten Skov 
Miljøeffektiv teknologi eller miljøteknologi i de nordiske lande

En undersøgelse af de nordiske landes aktiviteter på området i årene 2004-2011

Karsten Skov

TemaNord 2012:517

ISBN 978-92-893-2344-4

http://dx.doi.org/10.6027/TN2012-517

(C) Nordisk Ministerråd

Denne rapport er udgivet med finansiel støtte fra Nordisk Ministerråd. Indholdet i rapporten afspejler dog ikke nødvendigvis Nordisk Ministerråds synspunkter, meninger, holdninger eller anbefalinger.

\section{www.norden.org/publikationer}

\section{Det nordiske samarbejde}

Det nordiske samarbejde er en af verdens mest omfattende regionale samarbejdsformer. Samarbejdet omfatter Danmark, Finland, Island, Norge og Sverige samt Færøerne, Grønland og Åland.

Det nordiske samarbejde er både politisk, økonomisk og kulturelt forankret, og er en vigtig medspiller i det europæiske og internationale samarbejde. Det nordiske fællesskab arbejder for et stærkt Norden i et stærkt Europa.

Det nordiske samarbejde ønsker at styrke nordiske og regionale interesser og værdier i en global omverden. Fælles værdier landene imellem er med til at styrke Nordens position som en af verdens mest innovative og konkurrencedygtige regioner.

\section{Nordisk Ministerråd}

Ved Stranden 18

1061 København K

Telefon (+45) 33960200

\section{www.norden.org}




\section{Indholdsfortegnelse}

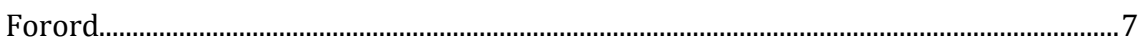

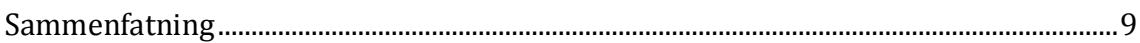

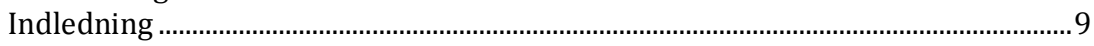

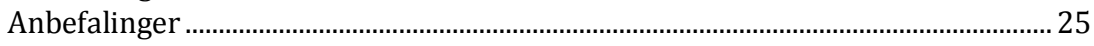

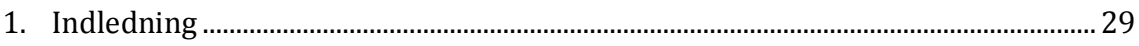

2. Danmarks indsats for miljøeffektiv teknologi 2004-2011...................................... 49

2.1 Dansk erhvervslivs aktiviteter inden for miljøeffektiv teknologi ................ 49

2.2 Vurderinger og initiativer for miljøeffektiv teknologi i Danmark................. 53

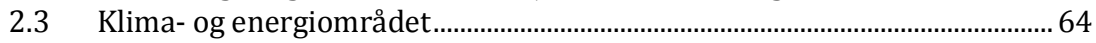

2.4 Miljøeffektive landbrugsteknologier .............................................................. 77

2.5 Erhvervsrelateret indsats for miljøeffektiv teknologi.................................... 83

2.6 Transportrelateret indsats for miljøeffektiv teknologi................................... 85

$2.7 \quad$ Forskellige politiske drøftelser i Danmark ........................................................ 86

2.8 Danske eksempler med international succes ..................................................... 88

$2.9 \quad$ Arbejdet med efterspørgsel i Danmark ......................................................... 90

2.10 Konklusion på Danmarks aktiviteter............................................................... 91

3. Finlands indsats for miljøteknologi 2004-2011 ........................................................ 93

3.1 Finsk erhvervslivs aktiviteter inden for miljøteknologi ................................ 93

3.2 Vurderinger og initiativer for miljøteknologi i Finland .................................... 95

3.3 Finske eksempler med international succes...................................................110

3.4 Arbejdet med efterspørgselssiden i Finland.................................................112

3.5 Konklusioner på Finlands aktiviteter............................................................114

4. Islands indsats for miljøteknologi 2004-2011 ….................................................117

4.1 Islandsk erhvervslivs aktiviteter indenfor miljøteknologi .........................117

4.2 Vurderinger og initiativer for miljøteknologi i Island...................................119

4.3 Tilskud fra den islandske regerings side........................................................126

4.4 Islandske eksempler med international succes..............................................131

$4.5 \quad$ Arbejdet med efterspørgselssiden i Island...............................................135

4.6 Konklusion på Islands aktiviteter..................................................................136

5. Norges indsats for miljøteknologi 2004-2011 …..................................................141

5.1 Norsk erhvervslivs aktiviteter inden for miljøteknologi..............................141

5.2 Vurderinger og initiativer for miljøteknologi i Norge ...................................142

5.3 Den norske regerings strategi for miljøteknologi i 2011 ..............................153

5.4 Den norske regerings program for miljøteknologi........................................160

5.5 Norske eksempler med international succes ...................................................165

5.6 Arbejdet med efterspørgselssiden i Norge......................................................167

5.7 Konklusion på Norges aktiviteter.................................................................167

6. Sveriges indsats for miljøteknik 2004-2011 ............................................................171

6.1 Svensk erhvervslivs aktiviteter inden for miljøteknik .....................................171

6.2 Vurderinger og initiativer for miljøteknik i Sverige.....................................173

6.3 Overblik og samlede tiltag fra regeringens side.............................................182

6.4 Den svenske regerings strategi for miljøteknik i 2011 ..................................188

6.5 Svenske eksempler med international succes ...............................................190

6.6 Arbejdet med efterspørgselssiden i Sverige ...................................................193

6.7 Konklusion på Sverige aktiviteter .................................................................194

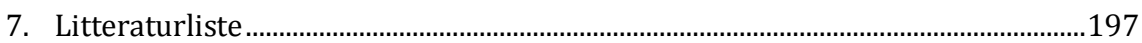




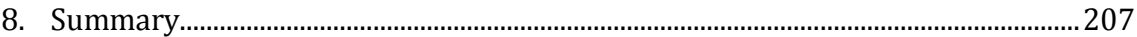

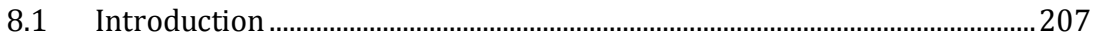

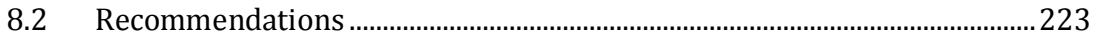




\section{Forord}

I Norden er vi gode til bæredygtig udvikling, grøn vækst, grøn økonomi og miljøteknologi. Men analyser viser, at vi kan blive langt bedre. Derfor bør vi være mere opmærksomme på, hvordan vi kan opnå dette, end på at rose os selv for, hvad vi allerede har opnået. Vi har ikke gjort nok, slet ikke nok. Vi må se fremad. Miljøteknologi er en del af grøn vækst eller grøn økonomi, da der er tale om de teknologiske løsninger på miljøproblemer, som kan påvirke den samlede økonomi. Denne erkendelse er vokset i takt med truslen fra klimaændringerne og finanskrisen.

Klimaændringerne viser sig med stadig stigende kraft. Videnskabelige analyser beretter om stigende temperaturer på op til 6 grader inden 2100 og om øget ekstremvejr. Ressourceknaphed rammer os også i stigende omfang, ikke mindst forårsaget af øget befolkningsvækst og globalt øget forbrug. For mange naturressourcer viser der sig en fremtidig sandsynlig knaphed, som vil ændre mange menneskers dagligdag. Konklusionen på dette trusselscenarie er, at vi må handle. Vi skal opnå markante ændringer. Helst globalt, men her viser det sig ofte, at enigheden af forskellige årsager er vanskelig at opnå. Derfor må vi handle lokalt og regionalt om muligt. I denne situation er der en unik mulighed for at bruge det nordiske samarbejde bedre. Norden må vise, at vi kan gøre det meget bedre end hidtil. Norden skal være ledende inden for grøn vækst.

Publikationen om miljøteknologi beskriver de nordiske landes indsats på dette område i årene fra 2004-2011. Starttidspunktet er bestemt af EU Kommissionens initiativ om en fælles EU-handlingsplan for miljøteknologi i 2004, og man kan i beskrivelsen af de enkelte lande se, hvordan man bliver stadig bedre til at arbejde med temaet. Publikationen forsøger at afdække, hvad de nordiske lande har gjort på området i form af beskrivelse af strategi, handlingsplaner, tilskudsprogrammer og påvirkning af efterspørgslen ved regulering etc. Der viser sig et billede af lande, som alle melder ud, at de vil gøre virkelig meget for miljøteknologi. Det har dog været vanskeligt at måle resultaterne af tilltagene, da der mangler evalueringer af indsatsen.

Også i efterspørgslen efter nye teknologiske løsninger viser projektet, at det er vanskeligt at afdække detaljerede eksempler på reguleringer eller økonomiske virkemidler, som fremmer efterspørgslen. Det virker som om, man ikke er helt så gode til at følge op på, hvordan teknologierne skal spredes og blive mere almindelige, for til sidst helt at afløse "gamle“ og utidssvarende løsninger.

Den foreliggende rapport er tænkt som et debatindlæg, der tilmed har en række direkte anbefalinger til landene. Der er også materiale til 
det videre fælles arbejde, hvor man kan styrke de positioner, som allerede er udviklet, både for det enkelte land men også for fællesskabet og for at skabe international opmærksomhed og øget nordisk konkurrencekraft. Miljøministrene har gennem denne rapport et grundlag for konkrete områder, hvorpå det nordiske samarbejde bedst kan udvikles og hvordan en skærpet miljøpolitik kan bidrage til grøn vækst. Dels gennem samarbejde om udviklingen af tekniske løsninger, dels gennem regulering og stimulering af efterspørgslen på miljøteknologi.

Det er vort håb i Nordisk Ministerråds sekretariat, at rapporten skal skabe en debat, som kan føre til en positiv udvikling for miljøteknologi, som igen kan hjælpe med at fremme grøn vækst og grøn økonomi.

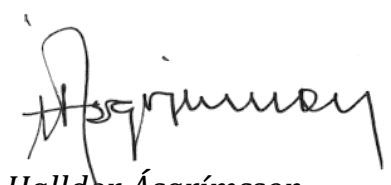

Halldor Ásgrímsson

Generalsekretær

Nordisk Ministerråd 


\title{
Sammenfatning
}

\author{
Indledning
}

Formålet med publikationen har været at beskrive de nordiske landes indsats for at fremme miljøeffektiv teknologi eller miljøteknologi. Vægten i denne beskrivelse har været på løsninger af miljøproblemer snarere end vægt på erhvervspotentiale. Det primære har været at vurdere status og se på forbedringsmuligheder land for land. Men hertil har det også været interessant at se på forskelle og ligheder de nordiske lande i mellem, samt at vurdere om der er muligheder for bedre samarbejde for at nå videre ved andres hjælp.

Med udgangspunkt i EU-kommissionens initiativ om en fælles EUhandlingsplan for miljøteknologi fra 2004 blev aktiviteter i de enkelte nordiske lande, dvs. Danmark, Finland, Island, Norge og Sverige, for årene 2004-2011 beskrevet. Helst med fremadrettede perspektiver om muligt.

Intensionen var at indsamle det skrevne og formulerede materiale fra hvert af de nordiske lande og tegne et billede af, hvad der er sket og sker i de enkelte lande. På denne baggrund blev der formuleret spørgsmål til de enkelte lande om, hvad man havde af materiale og initiativer, indenfor f.eks. strategier, tilskud/støtte, fremme af efterspørgsel etc. Der er blevet fokuseret på antallet af virksomheder, og hvilken eksport disse virksomheder har, som en indikator for international styrke.

Herefter gennemgås aktiviteter og rapporter fra de enkelte lande og ikke mindst strategier og tilskud/støtte i landene på området for miljøeffektiv teknologi eller miljøteknologi. Et særligt afsnit beskriver efterspørgselssiden i de enkelte lande, og der er endvidere et afsnit om eksempler på virksomheder med international succes. Endelig sluttes hvert landeafsnit af med en konklusion på, hvad beskrivelsen og analysen gav af resultat.

Nedenfor beskrives, efter nogle korte bemærkninger om tendenser, hvert land med sin indsats kort som et resume af konklusionsafsnittet om landet. Yderligere detaljer fås naturligvis ved at læse den detaljerede gennemgang af landet og konklusionsafsnittet under denne gennemgang. Det skal siges, at det er forsøgt at holde en nogenlunde ensartet disposition fra land til land. Dette er dog ikke muligt, idet der er stor forskel i, hvad man konkret har gjort og ikke mindst i, hvilket og hvor meget materiale, der er tilgængeligt landene imellem. Landene kommer i alfabetisk rækkefølge. 


\section{Tendenser}

Det synes nærmest umuligt at få en bindende international klimaaftale til afløsning for Kyotoprotokollen. Samtidig kommer der rapporter fra FN's klimapanel IPCC og IEA, som viser at det bliver varmere hurtigere end man havde regnet med. Det bliver nærmest umuligt at holde en 2 graders grænse for stigning i temperaturen, og allerede nu er der vurderinger på en stigning på op til 6 grader inden 2100. Rapporter viser også, at udledningen af CO2 globalt fortsat stiger, og ekstremvejr bliver mere sandsynligt.

I denne situation med global handlingslammelse er det naturligvis meget vigtigt, at enkelte lande og gerne grupper af lande går foran og viser, at det kan lade sig gøre at nå nye resultater i innovation og gennemførelse, og dermed i nedsættelse af klimagasudledninger. En vis gensidig håndsrækning mellem disse lande kan vise sig at have stor værdi, og tilmed større værdi end man umiddelbart forestiller sig.

En anden tendens, som er central at fremhæve, er talen om grøn vækst eller grøn økonomi. Miljøeffektiv teknologi eller miljøteknologi synes allerede at være et lidt forældet tema. Grøn vækst eller grøn økonomi tager over med stor interesse fra mange regeringer. Som forklaret i indledningen er grøn vækst eller grøn økonomi en overordnet tilgang, mens miljøeffektiv teknologi er en underkategori under grøn vækst og som sådan en delmængde heraf. Det er for så vidt udmærket, at der også kommer interesse for en bredere tilgang, men svagheden er, at fokus bliver vanskelig at holde for miljøeffektiv teknologi. Det bliver uinteressant i offentlighedens og regeringers øjne, selvom der er brug for stabilitet og kontinuitet, hvis man skal have succes i udvikling over tid. I forsøget på at få succes med miljøeffektiv teknologi på landsplan og internationalt er det nødvendigt at betragte interessen for grøn vækst som en meget positiv bølge. Det kan give grundlaget for en mere systematisk udvikling.

I denne forbindelse skaber EU Kommissionens skiftende sprogbrug også en vis forvirring om, hvor vi skal hen, og hvad der er vigtigt. Strategiskift fører nu engang til manglende kontinuitet og forvirring om kursen for indsatsen.

En tredje tendens eller observation må siges at være, at området hele tiden udvikler sig med nye eksempler, rapporter, strategier og aktører. Dette gør det vanskeligt at fastholde analysen. Situationer ændrer sig hele tiden. Projektet er dermed udtryk for en status i de nordiske lande pr. 1. december 2011, hvor der er sat afslutning for projektet.

Samlet set må man sige, at mængden af materiale, aktører, beslutninger, eksempler er eksploderet i de seneste par år. Det gør det nærmest umuligt at finde vej i et område som miljøeffektiv teknologi eller miljøteknologi, som synes at have mange tilhængere og dermed stor mulighed for succes. Med successen og ikke mindst flere tilskudsmidler flokkes virksomhederne om temaet og sender mange signaler om innovation, succes etc. 


\section{Danmark}

I Danmark omfatter sektoren for miljøeffektiv teknologi ca. 500 virksomheder. Eksporten kan opgøres til 85 mia. DKK i 2010 med 55 mia. DKK til energisektoren, som rimelig sikkert og et meget usikkert beløb på 30 mia. DKK til miljøsektoren. Der er dog et ret stort behov for, at det statistiske arbejde prioriteres højere. Energistyrelsen og Miljøstyrelsen bør være centrale i dette arbejde henholdsvis for klima/energi og miljø, om end andre aktører udmærket kan være hovedkræfter.

I Danmark lavede man i 2007 en samlet statslig strategi for miljøeffektiv teknologi, som dog snart vidste sig ikke at hænge sammen, da klima/energi blev udskilt fra Miljøministeriet og et selvstændigt Klimaog Energiministerium blev dannet. Herefter er der blevet kørt i et kli$\mathrm{ma}$ /energispor og et miljøspor.

Klima/energiindsatsen er den største og mest spændende satsning i Danmark med tilskudsmidler til lidt over 1 mia. DKK i hvert af årene 2010 og 2011. Størrelsesordenen ser ud til at fortsætte selv om det største program, EUDP, får lidt mindre i 2012. Klima/energi har nået en flot form med en samlet årsrapport for de mange programmer, som eksisterer $\mathrm{i}$ Danmark. Det interessante ved klima/energi er naturligvis også den stadig mere direkte målsætning om et samfund uden fossile brændstoffer, som lokker eller tvinger innovationen frem. Der skal naturligvis økonomiske styringsmidler og betydelig regulering til for at nå resultatet.

Miljøområdet har været stærkere i 2008-2009 end i 2010-11, hvor der har været relativt færre midler og mindre strategi. Nu er det dog besluttet, at lave et rigtigt Miljøteknologisk Udviklings- og Demonstrationsprogram (MUDP) fra året 2012 under inspiration fra det mere succesrige klima/energiområde. Måske kan der nu satses på lidt større projekter, gerne i samarbejde med andre programmer i Danmark.

De to andre fonde i Danmark, GUDP på landbrugsområdet og Fornyelsesfonden, er først kommet rigtig i gang i 2010 og har ikke vist mange resultater endnu.

En hovedanbefaling for Danmark er, at klima/energi skal gøre sit i øvrigt udmærkede arbejde bedre med mere materiale til offentligheden, samt en klarere kobling til Danmarks store visioner på klimaområdet. De øvrige områder dvs. MUDP, GUDP og Fornyelsesfonden bør kunne hjælpe hinanden med at fremme en mere sammenhængende indsats.

\section{Finland}

I Finland synes det bedste bud på antallet af virksomheder at være omkring 400 virksomheder. Clean Tech Finland opgør imidlertid antallet til ca. 2.000 virksomheder, uden at man bliver overbevist om statistikgrundlaget herfor. Sektoren er vurderet til at have en omsætning på 1217 mia. EUR i 2010. Dette tal fastsætter Clean Tech Finland til 18 mia. EUR. I 2006 blev det vurderet, at eksporten kunne fastsættes til 2,25 mia. EUR, mens Clean Tech Finland får dette tal til 13,5 mia. EUR i 2010. På denne baggrund er det rimeligt at konkludere, at der er et stort behov 
for talmateriale, der kan give en bedre forståelse for sektorens størrelse, og hvad der reelt sker. En statslig myndighed bør kobles på et sådant årligt talmateriale for at sikre kontinuiteten.

Den uafhængige finske innovations fond, Sitra, har promoveret området frem i en række år. Sitra lavede i 2007 Finlands første handlingsplan for miljøteknologi, hvor visionen var, at Finland skulle være det mest kendte cleantech land i verden i 2012. Sitra efterspørger i sit forslag til strategi en strategisk ejer af handlingsplanen, som kun kan være regeringen. Den finske regering svarer kun indirekte ved at nævne miljøteknologi, som et område, der prioriteres.

Det kan nævnes, at Finland måske er verdens stærkeste forskningsog innovationsland. Arbejdet med forskning og innovation står meget stærkt i Finland. Man har også arbejdet mere end de andre nordiske lande med brugerdrevet innovation, herunder miljøteknologi, som et middel til at fremme innovation. Finland arbejder mere intensivt med efterspørgselssiden and de andre nordiske lande ved bl.a. at udgive en publikation om regulering som efterspørgselsdriver. Finland har endvidere fokuseret mere på patenter end de andre nordiske lande.

Det nærmeste man kommer en ny strategi for miljøteknologi i Finland er den finske finansieringsstyrelse for forskning og innovation Tekes' publikation om grøn vækst - Finlands position i miljøteknologi. Drøftelser om grøn vækst og grøn økonomi har allerede kørt i Finland i et par år. Tekes konkluderer, at Finland stadig ikke har en klar strategi og en tydelig politik for grøn vækst og miljøteknologi. Tekes' rapport lover godt for fremtiden for miljøteknologi i Finland, men den skal naturligvis implementeres. Selvom regeringen arbejder med flere lovende initiativer om bioøkonomi, naturressourcer og nævner ambitioner på det miljøteknologiske områder, er der behov for en mere klar samlet regeringsudmelding fra den finske regering. Dette behøver ikke at være noget større arbejde, men kan udmærket gøres i form af en mindre publikation.

\section{Island}

I Island vurderes det, at der er lidt over 40 virksomheder, som kan tælles med til gruppen af miljøteknologiske virksomheder. Over halvdelen af disse virksomheder arbejder med energiteknologi, herunder 8 med speciale i geotermisk energi. Den årlige omsætning skønnes at være 700 mio. DKK og antal ansatte kan fastsættes til ca. 1.200, mens eksporten kan fastsættes til 325 mio. DKK i 2010. Tallene er meget usikre, men bedre end det man hidtil ser om sådanne opgørelser i Island. Der kan ikke herske nogen tvivl om, at der er et stort behov i Island for at få en mere kontinuerlig kortlægning af området år for år. Dette gælder ikke kun statistik om sektoren, men også analyser af delsektorer. Her har man set en analyse af den geotermiske sektor, som lover godt.

De statslige aktører i Island har stort set ikke interesseret sig for miljøeffektiv teknologi eller miljøteknologi under opstarten i EU med ETAP osv. De har ikke rigtig gjort noget andet end betragtet miljøteknologi, 
som enhver anden form for innovation og udvikling. Interessen er kommet fra en række virksomheder, som har set mulighederne for udvikling.

Med parlamentets arbejde med grøn økonomi og rapporten herom har Island dog taget et meget stort skridt fremad. Ingen andre lande i Norden har lavet en så detaljeret rapport om grøn økonomi, hvilket er bemærkelsesværdigt. Dermed har Island på en måde bragt sig på linje eller er i hvert fald godt med fra at have ignoreret området rimeligt længe. De andre nordiske lande bør interessere sig for rapporten om grøn økonomi, når den snart forelægger på engelsk. Man kan håbe, at Islands regering vil implementere samtlige anbefalinger i rapporten på en effektiv måde.

Island har en helt unik situation internationalt med de store geotermiske kilder. Allerede nu udnyttes de geotermiske kilder til elektricitet, og der er tilmed en stor del af energien, som i selve udnyttelsen går tabt. Så man kan nå meget længere i udnyttelsesgrad. Internationalt er der dog en begrænsning i eksport mv., fordi langt de fleste lande ikke har samme geotermiske forhold som Island. Islands energikilder bør kunne udnyttes til at fremme en langt mere miljøvenlig transportsektor, hvilket der også arbejdes på. Det kan dog gøres langt bedre med mere fokus end i dag. På dette område og andre sideeffekter fra de geotermiske kilder synes Island at have store muligheder for at udvikle sig til et interessant miljøteknologisk land.

Også samlet set, som det måske første klimagasneutrale samfund i verden, kan Island nå meget langt. Det er naturligvis en diskussion om, hvordan man skal gribe opgaven an. Det er forståeligt, at Island ønsker at tiltrække produktion af f.eks. aluminium, som kan gøres ekstra billigt ved at udnytte billig energi. I sådanne situationer må man vurdere, hvordan man kan opnå de bedste helhedsløsninger.

Ud over at gennemføre anbefalinger fra rapporten om grøn økonomi bør den islandske regering udarbejde en strategi og en langsigtet handlingsplan for fremme af miljøteknologi. Dette er nok den vigtigste anbefaling for Island. Herudover skal disse aktiviteter gennemføres effektivt med bedre og mere målrettede tilskudssystemer, bedre anvendelse af økonomiske styringsmidler, samt fremme af efterspørgslen, hvor det giver mening i et lille land som Island.

\section{Norge}

I Norge er antallet af virksomheder i den miljøteknologiske sektor opgjort til ca. 300 i 2011. De har en omsætning på 18 mia. NOK og 6.000 ansatte. Eksporten er opgjort til 6,7 mia. NOK i 2010. Denne eksportopgørelse bygger på 114 virksomheder og må anses for at være rimelig konservativ. Eksporttallet kan meget vel være større. Der bør i Norge være en styrkelse af statistik for miljøteknologi, både hvad angår antal af virksomheder og eksport, samt gerne underinddelinger for at give det bedste billede. En statslig aktør bør involvere sig i dette statistikarbejde eller udpeges hertil. Det bør i det mindste have en større opmærksomhed. 
I perioden fra 2004-2007 var der mest fokus på området i Norge med miljøteknologiprojektet under Statens Forurensningstilsyn, hvor Statens Fourensningstilsyn, Innovasjon Norge og Norges Forskningsråd arbejdede sammen om at udvikle området. Udviklingsarbejdet fortsætter under den næste periode fra 2008-2011 med Det Strategiske Råd for Miljøteknologi med flere rapporter på et generelt højt kvalitetsniveau.

Som helt centralt i Norge må man nævne regeringens nye strategi for miljøteknologi i 2011. Strategien bygger på en række gode rapporter om miljøteknologi, som er blevet udarbejdet i Norge. Den har en kvalificeret udformning med fokus på 6 centrale dimensioner og et program for miljøteknologi med en ekstrabevilling på 500 mio. NOK over 3 år, primært placeret i Innovasjon Norge. Med denne strategi starter en ny fase for arbejdet med miljøteknologi i Norge.

I Norge er der 3 aktører for tilskud/støttemidler: Innovasjon Norge for større bevillinger, gerne demonstrationsanlæg, Norges Forskningsråd med fokus på forskning og en række forskningsbaserede netværk, samt Enova, som er aktør på energiområdet.

En hovedanbefaling til Norge er, at den nye strategi er et udmærket afsæt til at løfte ambitionen i Norge om at være bedre på miljøteknologi. Den må dog føres ud i livet med bedre styr på statistik, teknologiområder, styringsmidler og indsatser etc., så der kan komme mere sammenhæng mellem politikudmeldinger og styringsmidler eller indsats.

\section{Sverige}

I Sverige har der været ganske meget fokus på tal om sektoren for miljøteknik, som er det brugte begreb i Sverige. Det samlede antal virksomheder opgøres til 6.500 i 2009, hvoraf der dog er et stort antal enmandsvirksomheder. Der vurderes at være ca. 40.000 ansatte med en omsætning på 119 mia. SEK. Eksporten er for 2009 vurderet til at være 40 mia. SEK. Uden tvivl haves et godt statistisk grundlag i Sverige til at lave en bedre vurdering af antallet af virksomheder. Den nye svenske strategi taler om nogle hundrede virksomheder. Dette kan givetvis være 400500 virksomheder med tanke på Sveriges økonomiske størrelse. Myndigheden for tillväxtpolitiska studier har fremover fået til opgave at forbedre det svenske talmateriale.

Som noget helt særligt i Norden har Sverige lavet en særlig enhed for at fremme miljøteknologi, Swentec, Sveriges miljøteknikråd. Swentec blev etableret i 2005 og blev lukket med udgangen af 2010. Swentec havde et budget årligt på 10-12 mio. SEK og det seneste år 7 ansatte. Samlet set må man sige, at Swentec har formået at løfte arbejdet i Sverige for miljøteknik med en lang række af aktiviteter. Swentec har tilmed lavet et forslag til handlingsplan på området. Man kan slå fast at skal et område bringes fremad, er en central enhed med kun denne opgave en oplagt mulighed at anvende. På en måde er det ikke en fordel for Sveriges miljøteknik, at man lukker Swentec, Man kan kun håbe, at den nye 
strategi vil være så meget mere målrettet, at den i gennemførelsen kan løfte noget af det arbejde, som Swentec har udført.

Fra den svenske indsats er det værd især at nævne hållbare städer, som helt unik blandt de nordiske lande. Intet andet land har taget opgaven med at fremme bæredygtige byer ved at lave et særligt program for dette. Der er ganske meget arbejde med bæredygtige byer, både fra delegationen selv og fra Riksdagen, men også fra VINNOVA, som har lavet en særlig rapport om perspektiverne ved at arbejde konstruktivt med bæredygtige byer. De andre nordiske lande kunne virkelig lære noget af Sverige på dette vanskelige område.

Den svenske regering offentliggør sin nye strategi for miljøteknik den 1. september 2011 som tilmed hedder strategi for udvikling og eksport af miljøteknik. Strategien omfatter især det internationale område og eksporten. Strategien er prisværdig kort og meget målrettet på en række centrale områder. Der er ikke så mange anbefalinger, som man tidligere har arbejdet med, hvilket givetvis er en fordel. Den skal følges op, og der synes blandt andet at mangle et klart centrum for ansvaret for strategien. Der er dog i Sverige kommet en meget klar regeringsudmelding, om end der stadig mangler en klarere arbejdsdeling mellem statslige aktører.

\section{Miljøeffektiv teknologi og/eller miljøteknologi}

Projektet startede med at tage udgangspunkt i begrebet miljøeffektiv teknologi, der som det engelske begreb „ecoefficient technology“ har udgangspunkt i EU's ETAP arbejde. Dette var bestemt ud fra opfattelsen, at miljøeffektiv teknologi bedre kunne rumme også specielt klima- og energiområdet, mens miljøteknologi nok blev opfattet som mere gammeldags. Gennemgangen viser, at alle de nordiske lande er meget prægede af ETAP-indsatsen og fremhæver, at den måde de anvender begrebet på er i overensstemmelse med ETAP. Herved bliver det tydeligt, hvor centralt EU's aktiviteter står. De påvirker medlemslandene i betydelig grad og også lande som Norge, der i vidt omfang følger EUkommissionsaktiviteter. Man kunne ønske sig, at ETAP holdt sin fornyelseskraft ved lige.

Det viser sig, at Norge, Finland, og Island anvender begrebet miljøteknologi, Sverige anvender miljøteknik, mens kun Danmark bruger miljøeffektiv teknologi, og Danmark har tilmed kun har gjort det i begyndelsen af perioden 2004-2011. Nu bruger Danmark også hyppigt miljøteknologi. Derfor er resultatet, at man i de nordiske lande hyppigst bruger begrebet miljøteknologi. Det er også udmærket, når blot det i forståelsen også indeholder klima- og energiområdet, hvilket det ofte gør. Det synes imidlertid ikke så meget at være fra klima- og energifolkene side, eftersom de ofte bruger begrebet klima- og energiteknologi. Det vil nok under alle omstændigheder være vanskeligt at få et begreb, som alle identificerer sig. Derfor må man konkludere, at anvendelsen af et fælles begreb ligeså godt kan være miljøteknologi som miljøeffektiv teknologi. 
Cleantech begrebet bruges også hyppigt, typisk i internationale sammenhænge, fordi dette begreb opfattes som mere moderne og måske tilmed smart. Mange sammenslutninger af firmaer kaldes sig cleantech network. Det virker mere moderne og mere internationalt.

\section{Virksomhederne}

Antallet af virksomheder, samt antallet af beskæftigede, omsætning etc. Inden for miljøeffektiv teknologi er ganske interessant, eftersom det angiver, hvor stor en del af samfundsøkonomien, der kan henregnes til denne sektor. Tilmed er det vigtigt, hvis et land skal satse på et område, at vide præcist, hvad man har med at gøre og ikke arbejder med en forkert opgørelse, der måske er præget af et modefænomen. Der er eksempler på misforståelser af tendenser eller bølger, f.eks. IT-boblen, biotekinteresse, som ikke synes at holde osv. Det ville være meget uheldigt, hvis miljøeffektiv teknologi eller miljøteknologi, grøn teknologi viser sig at være et modefænomen, som ikke kan holde distancen ret længe. Derfor er et solidt talgrundlag vigtigt for docering af politik, styringsmidler, etc. Kun herved kan den bedste strategi gennemføres optimalt. Ingen kan være tjent med overdrivelser. Det vil kun virke i en kort tid.

Det er imidlertid ikke nemt at opgøre antallet af virksomheder, fordi hidtidig statistik ikke kan håndtere miljøeffektiv teknologi som en branche. Det er en sektor, som går på tværs af mange brancher og områder. Dette er vanskeligt at håndtere, men måske også noget af det mere interessante, fordi det hermed bliver ganske omfattende.

Det er altså ganske vanskeligt at definere, hvilke virksomheder som skal med i sektoren. Hvad med det finske selskab KONE's supermoderne elevatorsystem, som bruger meget mindre energi end de hidtidige ${ }^{1}$ systemer? Man kommer virkelig i tvivl, om dette skal med, eftersom det åbenlyst er en meget effektiv teknologi set med energiteknologiske briller. KONE's pjece er imponerende læsning. Det vil være truende for afgrænsningen, hvis alle nye produkter, som er blevet meget energieffektive, skal med, idet stort set alle nye produkter også ofte er blevet langt mere energieffektive end de produkter, som de erstatter.

Der er endvidere mange andre afgrænsningsproblemer. Skal små virksomheder med? De fleste vil vel sige, at énmands virksomheder nok ikke skal tages med. De forvirrer billedet. Man kunne sætte en fornuftig grænse ved 5 ansatte, så giver det god mening. Der er ligeledes problemet med miljøvægtningen af virksomheder, sådan som det praktiseres i Norge. Herved kommer kun relevante dele af en større virksomheds aktiviteter med. Dette er stærkt anbefalelsesværdigt.

${ }^{1}$ KONE: Planlægning frem til 2050. KONE Eco-efficient-løsninger, 2 sider. 
Rapporten vurderer antallet af virksomheder i Danmark til at være ca. 500, Finland til at have over 400, Island til at have 40, Norge til at have 300, og Sverige til at have måske 600. Disse tal er dog yderst usikre, eftersom der er mange opgørelser i landene. I Danmark er der tilmed flere bud fra samme konsulentvirksomheder og i Finland et vedholdende bud på 2.000 virksomheder.

Der er også en tendens til, at virksomhedssammenslutninger i landene opgiver alt for mange virksomheder, som omfattet af miljøeffektiv teknologi. Det kan man kun være interesseret i som interesseorganisation. Det er i den grad blevet „in“ at være med på cleantech, og materiale herom eksploderer. Der er simpelthen penge i at markedsføre sig indenfor miljøeffektiv teknologi eller miljøteknologi.

Generelt må man anbefale, at der laves en årlig statistik over virksomheder i de enkelte lande. Som et minimum må man forklare, hvordan den er fastlagt eller afgrænset. Ellers kan man udefra ikke forstå, hvilke kriterier, der har været anvendt. I denne årlige statistik, eller i det mindste som grundlag herfor, bør der være en liste på virksomhedsnavne, så man ikke hele tiden skal genetablere en sådan fortrolig liste i et nyt konsulentfirma, som undersøger området. Det er vigtigt, at en statslig institution har overvågningsopgaven herfor.

Det er endvidere vigtigt, at man forsøger at nedbryde de enkelte områder. Kun herved vil man få en bedre fokus på enkelte områder, som har behov for en sådan fokus for at udvikle sig. Der skal nok bruges en simpel tilgang, så antallet af enkeltområder ikke eksploderer. Èn brugbar og nogenlunde simpel tilgang kan være den, som det danske konsulentfirma Brøndum \& Fliess ${ }^{2}$ bruger til at opdele miljøeffektiv teknologi eller cleantech, som er det begreb der bruges: Først opdeler man i to områder: ét for energi og ét for miljø. Herefter opdeler man hvert af de to områder i 4 nemlig: Energi: Grøn energiproduktion, effektivisering af energiforbrug, energiinfrastruktur, energilagring, og Miljø: Bæredygtige materialer, affald og genbrug, vand og spildevand, luft og miljø. For en nærmere beskrivelse henvises til konsulentrapporten. Man kan naturligvis have en ekstrakategori under både energi og miljø for at kunne få øvrige områder, som ikke lige lader sig rubricere, med ind i de 4 kategorier. Man kan have f.eks. CCS på energiområdet og jordrensning på miljøområdet i en sådan særkategori.

Man skal heller ikke holde sig tilbage fra at analysere andre eller tværgående områder som f.eks. bæredygtig byudvikling, økologisk landbrug, brændeovne, membraner, el-biler, hybridbiler osv. Gode analyser er en stor fordel og kan stærkt anbefales. Det skaber overblik og forståelse for, hvordan man kan fremme udviklingen ved brug af hvilke styringsmidler.

2 Brøndum \& Fliess: Cleantech - i vækstens tegn. Guldægget i dansk økonomi 2010, oktober 2010, 69 sider. 


\section{Eksport}

Eksporten af miljøeffektiv teknologi er valgt som en klar indikator på, hvor international stærk et lands aktiviteter inden for området er. Danmark er opgjort til i 2010 at have en eksport på 85 mia. DKK med 55 til klima/energi og 30 til miljø. Finland er opgjort til at have en eksport på ca. 13,5 mia. EUR i 2010. Island er vurderet til at have en eksport på 325 mio. DKK i 2010. Norge er vurderet til at have en eksport på 6,7 mia. NOK i 2010. I Sverige er eksporten opgjort til 40 mia. SEK i 2009, men den kan udmærket værre større. At Danmark har en stor eksport skyldes primært vindmølleindustrien, som er meget stor i Danmark. Finland har den største eksport, hvilket er et tal der kommer fra Clean Tech Finland, og ikke er bekræftet fra officiel finsk side.

Det er overordentlig vigtigt, at man kan bestemme eksportens størrelse rimelig korrekt. Med dette tal kan man vurdere, hvordan man står internationalt. Fokus kan naturligvis også være på import, som ofte vurderes som en svaghed for et land, hvorfor man forsøger at fremme hjemlandets aktører til at producere produkter, der bliver importeret. Drøftelserne i Danmark kan illustrere, hvor vanskeligt det er, når flere aktører forsøger at vurdere størrelser i eksporten. Her er der vurderinger samlet om klima/energi og miljø. Klima/energi synes at have fundet et vist fælles fodslag, men der er stadig drøftelser, mens miljødelen helt mangler et grundlag. Hvis man ikke har en aktør for hele området, som står for opgørelsen, som f.eks. i Sverige, kan man med fordel opdele eksportstatistik i en klima/energidel og en miljødel. Blot skal man huske ikke at lave overlap mellem de to opgørelser.

Det er også vigtigt, at der er en statslig aktør, som har det endelige ansvar for eksporttallet og sikrer en årlig opgørelse. Altså kontinuitet og åbenhed om tallene er central.

\section{Patenter}

Et andet område, som det kan være interessant at vurdere et lands styrke på, er antallet af opnåede patenter. Hvis man analyserer antallet af patenter over tid f.eks. i perioden 2000-2011 kan man få et godt overblik over, hvor stærkt et område man har med at gøre. Man kan både gøre dette samlet for miljøeffektive teknologi, men også nedbrudt på enkeltområder. Det giver et klart billede af, hvor delområdet står internationalt. Gennemgangen af de nordiske lande viser, at kun Finland har gjort dette systematisk som nævnt i Tekes' nye strategi om Finlands position i miljøteknologi: Mod grøn vækst? Her bruger man en vurdering af antallet af patenter til at sige noget om styrke. Det bør på denne baggrund anbefales, at hvert af de nordiske lande forsøger at opgøre antallet af patenter, som en indikator på international styrke. 


\section{Tilskudsmidler}

Tilskudsmidler er vel det mest centrale styringsmiddel, som alle lande bruger til at fremme udviklingen eller gennemførelsen af miljøeffektiv teknologi. I udgangspunktet har der også i spørgsmålene til landene i analysen været stor fokus på størrelsen af tilskudsmidler, tilskudsområder, programstyring, resultater etc. Det viser sig imidlertid, at når en tilskudspakke er vedtaget og pengene fordelt til en tilskudsadministrator, følges denne beslutning stort set ikke op med krav om styring, afrapportering, evaluering etc. Hvis dette systematisk gennemføres, må det siges, at ske implicit som en del af det almindelige styringssystem hos administrator. Det er i hvert fald ikke noget, som man fortæller til omverdenen.

Der var ved projektstart en forventning om, at det lod sig gøre at opstille lister over områder og størrelser på tilskudsmidler, resultater etc. Det viser sig imidlertid hurtigt, at landene heller ikke selv er særlig gode til at skabe dette overblik. Så det er ikke noget, som er særlig tilgængeligt, og det er ikke lykkedes i dette projekt at få materiale frem, hvor tilskudsmidlernes størrelse er beskrevet meget detaljeret. De enkelte landeafsnit viser tal fra strategier og udmeldinger om fremtidig indsats, men det har ikke været mulig at skabe dette overblik tilbage i tid. Dette er uheldigt og bør kunne gøres bedre i fremtiden, hvis der kan skaffes mere information om tilskudsmidler.

Er der tilstrækkelig med tilskudsmidler? Nogle gange finder man i rapporter udsagn om, at der er tilstrækkelig med midler, andre gange kan man finde udsagn om, at der mangler midler. Der er midler til rådighed i alle nordiske lande. De kunne givetvis være større, idet de fleste programmer viser, at der ansøges om flere midler, end der er til rådighed. Omvendt er det klart, at man ikke bare skal tilbyde midler på en meget nem måde. Det skal ikke være for let at få midlerne, så får man ikke nok ud af midlerne. Generelt kan man vel sige, at det må være ret nemt at afsætte flere midler til tilskudsmidler, eftersom de som regel er små i en samlet størrelsesorden set i forhold til så mange andre udgiftsområder.

Tilskudsmidler kan gå til en række formål: forskning, udvikling og demonstration, nævnes hyppigt som 3 mål i en udviklingskæde. En sådan udviklingskæde gøres ofte mere detaljeret. Der er ingen tvivl om, at forskning hyppigt har fået flest midler. I EU har der også været en vis tilbageholdenhed overfor midler til demonstration, fordi det anses at være for tæt på generel statsstøtte. Dette synes imidlertid heldigvis at være fortid, idet man fra også EU's side har erkendt, at der skal ganske mange midler til at demonstrere anlæg i den virkelige verden og ikke kun på tegnebordet. Først sent i perioden 2004-2011 kommer der mere fokus på demonstrationsanlæg, som nødvendige for at teknologierne skal komme til ordentlig afprøvning. Og det må også siges, at har man ikke midler til demonstration, kan mange teknologier ikke afprøves i virkeligheden. Derfor bør man altid sikre sig, at der er midler til demonstrationsanlæg, faktisk rigelige midler. 
Generelt må det siges, at der stilles for få krav til tilskudsadministrator fra bevillingsmyndighedernes side. Tilskudsadministrator får som oftest ret store frihedsgrader i, hvordan man griber sagen an. Der bør som minimum stilles krav om information, formidling og evaluering ud over de aktiviteter, som normalt pågår om sikring af tilskudsmidlernes fornuftige anvendelse.

Et område, som bør have ord med på vejen, er tilskudsmidlernes udbudsform. Dette sker stort set altid ved ansøgninger til de forskellige programmer og ikke ved udbud. Der formuleres ofte temaer eller teknologiområder, som kan få støtte, men udbyderen af midler går sjældent særligt langt i krav, som f.eks. ved et rigtigt udbud. Dette skyldes givetvis, at det kan være ret vanskeligt at formulere specifikke krav. Ikke desto mindre kunne man godt beskrive teknologiområder ved brug af eksperter til at formulere et udbud, som virksomheder skulle byde på. Det tager naturligvis også tid og koster penge. Den samlede anbefaling må være, at tilskudsadministratorer bør arbejde mere med perspektiver og detaljer, og ikke kun give midler til ansøgninger uden at have detaljeret kendskab.

Noget, som også gør det vanskeligt at følge tilskudsmidler, er tilsagnets tidspunkt om tilskud til et projekt og udbetaling af midler. Typisk betales efter udført arbejde, eller i rater. Det betyder, at pengene falder, mens eller efter arbejdet er blevet udført. Herved bliver det nogle gange vanskeligt at følge midlerne. Og dette giver ofte anledning til misforståelse om, hvor mange midler der bruges. Det vil være naturligt, at man for hvert år lister, hvor mange midler, der er til rådighed. Dermed bruges udgangspunktet, altså midler til rådighed og ikke en eller anden fasetilgang. Så kan evalueringer vise, hvor meget der er blevet anvendt.

Ikke mindst for et lands egen skyld bør der føres en god og offentlig oversigt, hvilke midler der har været til rådighed, og hvordan midlerne er blevet anvendt. Enkelte ministerier ved ikke altid, hvad andre ministerier har gjort, så alene af denne grund bør der skabes bedre overblik.

\section{Mandskabsressourcer}

I udgangspunktet var idéen, at det lod sig gøre at opgøre antallet af folk, der i centraladministration og styrelser arbejder med tilskud etc., i hvert enkelt land. Det har imidlertid vist sig forholdsvist vanskeligt at få materiale herom. På enkelte programmer kan man få opgjort administrationens størrelse, men ellers er det ikke noget, som interesserer mange. Det er dog noget af det vigtigste i grundlaget for at skabe succes for området: at der er tilstrækkelig med mandskabsressourcer til at udføre indsatsen. Uden denne præmis er det nærmest umuligt at løfte et område, især i en udviklingsfase.

Dette gælder ikke kun tilskudsmidler, men også sagsbehandling og politisk betjening, skrivning af strategier og rapporter. Dette glemmes ofte af bevillingsmyndigheden, og tilmed er mange institutioner så økonomisk stramt styret, at det er yderst vanskeligt at få luft eller frihedsgrader til at 
løse opgaverne. Det siges i erhvervslivet, at skal innovation have gode kår, skal der fri leg til og god tid, ellers kommer der ikke rigtig noget ud af det. Sådan vil det også være for et område som miljøeffektiv teknologi eller miljøteknologi, som er relativt nyt og vanskeligt at håndtere i en udviklingsfase. Og dette gælder faktisk også i administrationsleddet. Der er generelt for få ressourcer og ofte for få erfarne mandskabsressourcer til, at området får den optimale opbakning. Der er tilmed ofte fokus på det kortsigtede og politisk signalgivende, i stedet for langsigtede og grundlæggende arbejde. Beviset herfor er ikke umiddelbart tilstede, men bygger på en erfaring om, hvor vanskeligt det er at fă tilstrækkelig med gode mandskabsressourcer.

Et eksempel som kan nævnes i denne sammenhæng er efterspørgselssiden. Efterspørgselssiden erkendes af samtlige lande som ganske vigtig, men man kan spørge: hvilke lande der har tilført fremme af efterspørgselssiden flere mandskabsressourcer i forbindelse gennemførelse af en strategi? Sikkert ingen.

Anbefalingen må på denne baggrund blive: sørg for at afsætte tilstrækkelig med mandskabsressourcer både til styring af tilskudsprogrammer og til opfølgning, ikke mindste til at fremme efterspørgslen. Med tilstrækkelig med mandskabsressourcer menes flere, end man som udgangspunkt ville have gjort eller rigelig i forhold til det normale.

\section{Strategier eller handlingsplaner}

Noget af det de nordiske lande er bedst til, er formuleringer af strategier eller handlingsplaner. Senest har vi set strategier fra Norge, Sverige, Island og til dels Finland, som er ganske flotte, og nok mere målrettede end de tidligere versioner, som sås først i perioden 2004-2011. Det der er vanskeligt ved strategier er at implementere opgaverne på en god måde, og at formidle dette løbende til offentlighed og aktører.

Anbefalingen er her, at man skal have bedre fokus på implementering og formidling af resultater mv.

\section{Eksempelstrategier og hjemmesider}

Alle nordiske lande har lavet eksempler på miljøeffektiv teknologi eller miljøteknologi, som de fortæller omverdenen laves i det pågældende land. Bedst er dette blevet gjort af Sverige, primært i kraft af Swentecs arbejde, med en eksempelsamling på 143 projekter, som kan bruges som en besøgsguide.

Beskrivelse af enkelte eksempler er første skridt på vejen til at få et bedre overblik. Det er ikke vanskeligt at lave sådanne enkelte cases, der kan illustrere, hvad der menes med gode eksempler. I det hele taget er det en rigtig god idé at lave en større eksempelsamling, gerne på engelsk, som kan bruges til international markedsføring.

Det kan anbefales, at hvert land laver beskrivelser tilgængelig på nettet over eksempler på perspektivrige teknologier. Den må også gerne henvise til geografisk placering af anlæg. 
Det er også vigtigt at have gode hjemmesider med beskrivelse af, hvad der foregår i landet på området. En sådan hjemmeside kan også udvikles med rapporter, henvisninger, oversigter etc. og må nærmest siges at være uundværlig. Erfaringen fra projektet er, at samtlige lande bør lave bedre hjemmesider om miljøeffektiv teknologi eller miljøteknologi. Det anbefales, at hvert land bruger flere ressourcer på at lave bedre hjemmesider om miljøeffektiv teknologi eller miljøteknologi.

\section{Venture kapital}

Virksomheder, som udvikler sig, har ofte brug for at tiltrække aktiv kapital, som vil investere i virksomhederne. Der er i hvert nordisk land lavet offentligt ejede fonde med venture kapital, som vurderer om man vil investere i perspektivrige virksomheder eller teknologier. Der er også privat venture kapital, som interesserer sig for direkte investeringer.

Projektet har ikke undersøgt markedet for venture kapital i de enkelte nordiske lande. Der står bemærkninger herom i mange publikationer, og venture kapitalfonde, især offentlige, udgiver også ofte publikationer, hvor man kan se, hvad de har investeret i. Årsagen til denne manglende undersøgelse skyldes, at man kan argumentere for, at venture kapital er et særligt område, som bør have sin egen fokus eller kan have sin egen fokus.

Det anbefales, at landene sikrer sig, at der er tilstrækkelig med venture kapital, såfremt virksomhederne efterspørger fremmed kapital.

\section{Efterspørgsel}

Man er i alle nordiske lande udmærket klar over, at det offentlige har en stor påvirkning på efterspørgslen af miljøeffektiv teknologi eller miljøteknologi. Dette fremgår af rapporter og ikke mindst de nye strategier, f.eks. i Norge og Sverige. Staten har via reguleringen en ganske særlig mulighed for påvirkning af markedet. Dette er erkendt. Der er imidlertid et stort spring fra denne erkendelse til en mere aktiv bearbejdning af markedet med efterspørgselsrettede instrumenter. De nordiske lande er i projektet blevet spurgt om tiltag til påvirkning af efterspørgselssiden, både generelt og i mere specifikke tilfælde. Samtlige svar bliver ganske generelle og ikke særligt konkrete. Det er tydeligt, at man ofte ikke arbejder så konkret med at tænke påvirkning af efterspørgslen ind i fremme af miljøeffektiv teknologi.

I Danmark er der lavet en publikation om de miljømæssige konsekvenser ved øgede offentlige indkøb. ${ }^{3}$ Denne rapport viser, at man kun kan opnå relativt små miljøresultater ved at anvende en øget andel af det offentliges indkøb på grønne indkøb. Det skyldes nok, at grønne indkøb skal vælge mellem produkter, som er tilladt, og derfor er potentialet ikke helt så stort, som man umiddelbart forventer.

${ }^{3}$ Se afsnittet om efterspørgsel under Danmark. 
Sverige er det land i Norden, som har gjort mest for at opfylde konkrete miljømål eller miljøkvalitetsmål. Her kan de andre nordiske lande lære meget af målfastsættelse og forsøg på opfyldelse. Det synes meget positivt, som dette arbejde fortsat bliver udviklet i Sverige.

Alle nordiske lande har arbejdet ganske meget med offentlige grønne indkøb eller udbud. Der er skrevet meget herom, og der tales hele tiden om, at der skal gøres mere, så andelen af grønne indkøb eller udbud stiger. Det er imidlertid hele tiden et frivilligt instrument, som man bruger. Der bruges ingen bindinger på området, primært fordi økonomien har en meget stor vægt, og det tillades ikke af finansielle årsager at kræve, at det offentlige skal indkøbe grønne leverancer eller varer med en klar præference foran den økonomiske tilgang. Det er relevant, at man vurderer grønne indkøb eller udbud med hensyn til miljøeffekter for at opnå størst mulig effekt og måske dæmpe forventningerne til, hvad der er muligt at opnå med en større indsats. Sverige har gjort mest på området og burde fortælle de øvrige nordiske lande præcist, hvad de kan gøre mere eller bedre.

En særlig form for grønne udbud kaldes udbud af teknologi eller udbud af innovation. Dette er et område, som er i udvikling. Det er givetvis nok bedst til meget målrettede projekter, som skal løse enkelte opgave, f.eks. færger, og ikke masseproducerede varer.

I Finland har man lavet en publikation om reguleringens påvirkning på miljøinnovationer. Publikationen er desværre på kun på finsk, hvilket naturligvis gør, at man i andre nordiske lande kun vanskeligt kan få fordel af dette arbejde og lære heraf. Egentlig burde publikationen oversættes til svensk eller engelsk og deles med andre interesserede. Man kan også sige, at samtlige nordiske lande burde gennemtænke regulering og efterspørgsel mere systematisk.

Det anbefales, at alle lande laver en rapport om, hvordan det offentlige eller staten kan påvirke efterspørgselssiden og laver procedurer for, hvordan det kan forbedres. Man skal tænke både i generelle baner, som f.eks. økonomiske afgifter, men også i helt specifikke eksempler som f.eks. NOx, hvor regulering og afgifter har haft gode resultater. En sådan rapport bør også overveje procedurer i det offentlige for at påvirke efterspørgslen.

\section{Miljøministeriernes rolle}

Miljøeffektiv teknologi eller miljøteknologi er i udpræget grad en miljødagsorden, om end den ofte tager form af en erhvervsfremmedagsorden. Det synes som om, at miljøvinklen ofte bliver negligeret i mange sammenhænge. Miljøministerierne optræder som regel som den svage part i arbejdet og har givetvis det vanskeligste område, nemlig regulering og $\mathrm{i}$ mindre grad tilskudsgivning, som må anses for et nemmere område. Afgifterne er ofte finans- og økonomiministeriers ansvar. Miljøministerierne har i nogle tilfælde ansvaret for tilskudsmidler, om end dette er undtagelsen snarere end reglen. I Sverige og Danmark har miljøministerier eller Naturvårdverket og Miljøstyrelsen forskellige tilskudsmidler og kan følge- 
lig bedre agere. Miljøministerierne bør inddrages tæt i beslutninger om tilskud, eftersom der er tale om et miljøområde og påvirkning af efterspørgslen ofte ligger i miljøministerierne.

Et område, som miljøministerierne bør tage mere højtidelig, er miljøvurdering af teknologi. Der er for mange frihedsgrader eller slaphed i den måde man miljøvurderer teknologi i de forskellige lande. Som regel er der ingen klare retningslinier eller publikationer herom. Især i situationer, hvor tilskud er spredt på en række aktører, kan det være vanskeligt at finde de mest støtteberettigede projekter ud fra miljøsynspunkter.

Energiministerierne eller energimyndighederne synes at være mere heldig stillet, fordi de ofte både har tilskudsmidler og reguleringsansvar. Herved opstår nogle fordele ved at have en god mulighed for at påvirke begge sæt af styringsinstrumenter.

Det kan anbefales, at Miljøministerierne arbejder mere med påvirkning af efterspørgslen og med, hvordan man miljøvurderer udvikling af teknologi eller hvilke teknologier, som er mest interessante ud fra miljømæssige synspunkter.

\section{Evalueringer}

På trods af at der er tale om et meget vigtig område efter regeringernes udmeldinger, er det meget småt med evalueringer af området. Dette skyldes vel nok primært, at indsatser kun har varet i en kortere årrække. Kun to rigtige evalueringer er fundet og en række evalueringer er undervejs.

Det kan varmt anbefales, at hele indsatsen eller dele heraf evalueres i de enkelte lande ud over naturligvis at foretage evalueringer af tilskudsprogrammer. Uden uafhængige evalueringer synes legitimiteten af en del af indsatsen at mangle.

\section{Grøn vækst eller grøn økonomi}

Grøn vækst eller grøn økonomi vil i et vist omfang overtage dagsordenen i de fleste lande. Det er mere interessant end det noget mere tekniske miljøeffektiv teknologi eller miljøteknologi. Grøn vækst er den mere direkte erhvervstilgang, hvor man forsøger at sætte gang i væksten ved hjælp af grønne tiltag eller reguleringer, mens grøn økonomi må siges at være den mere besindige strukturering af økonomien ved at dreje denne fornuftigt i retning af mere miljømæssigt rigtige eller fornuftige løsninger. Skal grøn vækst eller grøn økonomi lykkes på en grundlæggende måde, vil det kræve ændringer af en række samfundsstrukturer på en ganske radikal måde. Det vil også koste betydelige summer i opstartsfasen, om end meget tyder på, at det bliver mindst lige så billigt, ja, måske endnu billigere for samfundsøkonomien på længere sigt, især hvis man til fulde indregner miljøudgifterne/omkostningerne eller som det kaldes eksternaliteterne.

Ved fuld effekt fra grøn vækst eller grøn økonomi skal man ændre på en betydelig mængde faktorer, ikke mindst priserne ved f.eks. afgifter. Det viser sig allerede, at der er betydelige fordele for de økonomier, som allerede har formået at indføre grønne afgifter i et vist omfang og kan 
leve med dette i konkurrencen med andre økonomier, som intet har gjort endnu. Det står imidlertid også klart, at der er meget mere at hente ved at forøge denne indsats.

På sigt vil man sikkert se, at mange lande laver deres egne strategier for grøn vækst eller grøn økonomi, som Island lige har gjort. Hermed kan sådanne lande tage et skridt fremad, hvis de også sikrer en effektiv implementering heraf. En anbefaling til de nordiske lande må være at udforme sådanne nationale strategier for grøn vækst eller grøn økonomi og sikre en effektiv gennemførelse heraf.

Miljøeffektiv teknologi eller miljøteknologi er en forudsætning for grøn vækst eller en delmængde heraf. Uden en stærk udvikling på dette område vil det være nærmest umuligt at skabe en fornuftig grøn vækst eller grøn økonomi. Derfor bliver landene nødt til at udforme fornuftige og stærke strategier for miljøeffektiv teknologi og miljøteknologi, hvis de satser på grøn vækst og grøn økonomi.

\section{Det nordiske samarbejde}

Det nordiske samarbejde har allerede gjort en del for at fremme miljøeffektiv teknologi eller miljøteknologi. Dette kan gøres bedre i fremtiden, især hvis man hjælper de nordiske lande med at gøre det de er bedst til. I første omgang i landenes egen interesse, men dernæst for at vise andre nordiske lande, hvordan man har gjort, og ligeledes også lande uden for Norden.

\section{Anbefalinger}

Alle anbefalinger skal ses som et forsøg på at styrke de nordiske landes indsats for miljøeffektiv teknologi eller miljøteknologi. Hvis et land erklærer, at man ønsker at føre høj profil på området eller fremme udvikling og innovation på området, bør der være en interesse for at følge anbefalingerne. Et land bør dog foretage en vurdering af, om og hvordan man ønsker at følge en anbefaling.

\section{Fælles anbefalinger}

- Det anbefales, at man anvender miljøeffektiv teknologi eller miljøteknologi som begreb, samt at man klargør og gennemfører, at klima- og energiområdet er integreret i dette begreb

- Der bør laves en årlig statistik over virksomheder i de enkelte lande. Statistikken bør forsøge at fastlægge antallet af virksomheder, antal beskæftigede, omsætning, samt gerne foretage en opdeling på områder, f.eks. som foreslået ovenfor. Miljøvægtning af større virksomheder bør anvendes, samt man bør arbejde med en vis virksomhedsstørrelse, f.eks. 5 ansatte som minimum. En statslig myndighed bør have et endeligt ansvar for statistikken 
- Eksporten fra sektoren bør opgøres hvert år for at få en pejling af, hvordan det går internationalt. En statslig myndighed bør ligeledes have ansvaret for eksportstatistikken

- De nordiske lande bør regelmæssigt foretage opgørelser af antallet af patenter, som udtages i det enkelte land, for at få en pejling på innovationskraften

- Hvert land bør føre en god oversigt over, hvor mange midler der er til rådighed hvert år, og hvad de pågældende midler er blevet anvendt til, når året er gået

- Der bør stilles flere krav til tilskudsadministratorer om information og formidling af især resultater

- Sørg for at der er flere mandskabsressourcer til rådighed til styring af tilskudsprogrammer, opfølgning, analyser etc.

- Landene må sikre sig, at der er tilstrækkelig med tilskudsmidler og venture kapital til at opfylde rimelige behov, som virksomhederne giver udtryk for

- Landene må gå mere systematisk til værks for at støtte efterspørgselssiden, især med regulering. Grønne indkøb eller udbud bør overvejes at blive gjort mere bindende

- Der bør være evalueringer mere hyppigt, end det er tilfældet på nuværende tidspunkt

- Man bør sikre sig, at der er en god koordinering af et lands indsats mellem forskellige statslige aktører, ikke mindst mellem tilskudsadministratorer og reguleringsansvarlige, såfremt disse poster er adskilt

- Miljøministerierne bør være integreret i arbejdet, fokusere på at påvirke efterspørgslen samt interessere sig for miljøvurderinger af teknologi

- Hvert land bør udvikle bedre eksempelstrategier og hjemmesider, så det er lettere at følge udviklingen

- Man bør samarbejde mere internationalt, ikke mindst i forhold til en EU-dagsorden

- Ikke mindst for at styrke miljøeffektiv teknologi bør hvert land lave en strategi for grøn vækst eller grøn økonomi, samt implementere denne effektivt

\section{Anbefalinger for de enkelte lande}

For at skærpe interessen fra de enkelte lande er nedenfor fremhævet en hovedanbefaling for landet. Der fokuseres på handlingsplaner og strategier, men samtidig bør man huske på, at det kan gøres meget kort som f.eks. i Sverige.

\section{Danmark}

Danmark bør, som de andre nordiske lande, udarbejde en eller flere strategier, eftersom der er gået for lang tid siden den første fælles strategi blev færdig. Klima/energisiden bør lave en kort, klar handlingsplan, 
når der et ny klima/energiforlig på plads. Denne handlingsplan bør fokusere på koblingen mellem tilskudsmidler, reguleringer og målopfyldelse. Miljøsiden bør udarbejde en ny handlingsplan, som helst skal omfatte MUDP, GUDP og Fornyelsesfonden for herved at øge den samlede effekt af miljøindsatsen.

\section{Finland}

Finlands regering bør også, efter mange opfordringer, udarbejde en ny handlingsplan for at give miljøteknologi i Finland større vægt. Denne handlingsplan bør være kort og klar, og bør forholde sig til de efterhånden mange begreber om miljøteknologi, grøn vækst, bioøkonomi, naturressourcer etc. Der skal fokuseres mere på implementering.

\section{Island}

Island bør naturligvis implementere anbefalingerne i rapporten om grøn $ø$ konomi. Og Island bør ligeledes udarbejde en mere detaljeret handlingsplan for miljøteknologi, der også har en vis langtidssikring. Der bør ligeledes fokuseres på implementering.

\section{Norge}

Norge har allerede udarbejdet en ny strategi eller handlingsplan. Denne bør gennemføres, og der bør satses på at få bedre styr på en række detaljer i gennemførelsen, ikke mindst så der kommer bedre overensstemmelse mellem politiske udsagn og anvendelse af virkemidler, hvad end der er tale om tilskud eller reguleringer etc.

\section{Sverige}

Sverige har også for nylig præsenteret en ny strategi eller handlingsplan. Denne bør gennemføres, og der bør satses på at få implementeret anbefalingerne. Man bør være opmærksom på ikke at tabe det momentum, som Swentec skabte, ved sin målrettede indsats.

\section{Anbefalinger til de enkelte lande i samarbejdets ånd}

Det viser sig ofte, at alle er for mere samarbejde, men når det skal udføres har ingen ressourcer eller tid. Derfor foreslås her kun én eller ganske få konkrete anbefalinger, som tilmed er tænkt som en hjælp til selvhjælp. Hvert land har ydet noget unikt og kan fortælle om dette. Det vil naturligvis koste lidt at gennemføre det, men der vil givetvis være stor international interesse, ikke kun nordisk interesse herfor, og der vil også være hjemlig interesse. Der tales typisk om en publikation, som er pædagogisk, men også lidt mere ærlig end de plejer at være, når man skal promovere sit eget land.

Disse anbefalinger, som beskrives nedenfor, kan evt. drøftes på et fælles seminar. 


\section{Danmark}

Det foreslås, at Danmark, når man har et nyt klima/energiforlig på plads, udarbejder en pædagogisk publikation til, hvad der er gjort, og hvordan man griber udfasningen af klimagasser an. Danmark bør også lave en publikation om miljøeffektiv teknologi i landbrugssektoren, eftersom man tydeligvis på dette område har gjort en del, og der udestår stadig meget.

\section{Finland}

Finland har gjort en del på efterspørgsel og regulering og kan ved oversættelse, f.eks. til engelsk af materialet starte en god drøftelse. Finland kan også være bannerfører for brugerdreven innovation, som er nået langt i Finland. Dette kan der også arbejdes med.

\section{Island}

Island bør fortælle om sin indsats for grøn økonomi, samt om det store eventyr om brugen af geotermisk energi og de fremtidige perspektiver herfor.

\section{Norge}

Norge har en unik erfaring i CCS, carbon capture and storage i havbunden og bør fortælle om erfaringerne med at bruge denne teknologi. Norge har også en høj grad af effektivitet $\mathrm{i}$ at begrænse energiforbruget $\mathrm{i}$ industrien sammenlignet med andre nordiske lande ifølge Eurostat. Denne styrke i energieffektivitet i industrien kunne også gøres til genstand for en publikation.

\section{Sverige}

Sverige er foran på flere områder. Man bør lave en pædagogisk publikation om hållbare/bæredygtige byer, der viser hvor langt man kan nå i et enkelt land. Sverige kunne også promovere sig ved at fortælle om, hvad man har gjort for offentlige grønne indkøb og udbud, hvor det må vurderes, at man er førende i Norden. 


\section{Indledning}

I løsningen af miljøproblemerne er der de seneste år kommet en betydelig fokus på miljøeffektiv teknologi. Miljøeffektiv teknologi er alle teknologiske løsninger, som skaber mindre miljøbelastning og dermed fremmer et bedre miljø. Denne øgede fokus har f.eks. ført til, at EUkommissionen har iværksat en systematisk indsats for sammen med medlemslandene at fremme miljøeffektiv teknologi ved sin handlingsplan for fremme af miljøteknologi (ETAP). Internationalt har flere organisationer arbejdet med temaet, og en række lande har satset herpå, ikke mindst de nordiske lande.

Det har været drøftet intensivt, hvordan man kan øge miljødimensionen i de mere kendte temaer bæredygtig udvikling og grøn vækst. Uden tvivl skal man have stærke konkrete holdepunkter, ellers lykkes det ikke at fremme miljømæssige synspunkter i påvirkningen af udviklingen eller væksten. Et sådant konkret holdepunkt er de enkelte landes arbejde med miljøeffektiv teknologi. Den strategiske tilgang til miljøeffektiv teknologi omfatter alle miljømæssige forbedringer i udvikling og spredning af teknologi. Og dette vedrører både udbuddet af teknologi, hvor der typisk finansieres nye teknologier, men også i høj grad efterspørgslen efter teknologiske løsninger i form af regulering forstået bredt. Noget som sjældent erkendes i debatten, ikke mindst fordi miljøeffektiv teknologi af mange ses som en snæver teknologisk satsning uden relation til efterspørgselsvinklen.

Arbejdet med miljøeffektiv teknologi på en systematisk måde er egentlig først i en startfase, og potentialet er givetvis meget stort. Egentlig har arbejdet med miljøeffektiv teknologi eksisteret lige så længe som miljøpolitikken, men der kan argumenteres for, at den systematiske tilgang er startet med EU kommissionens arbejde med ETAP i 2004.

Dette oplægs påstand er, at der er betydelig mere dynamik og potentiale end hidtil erkendt i en større fokus på miljøeffektiv teknologi med det formål at fremme en mere bæredygtig udvikling eller vækst i samfundene. Denne fokus vil givetvis tage fart, hvis flere lande arbejder sammen, herunder også de nordiske lande.

De nordiske lande er på forskellige områder, bl.a. miljø, ofte tæt på hinanden i strategi og adfærd, om end de også ofte adskiller sig betydeligt i, hvordan de griber forskellige temaer an. Det er i sig selv interessant at forfølge en beskrivelse af, hvad der egentlig sker i de nordiske lande på området for miljøeffektiv teknologi. Det vil være denne publikations tema. 


\subsubsection{Formål med publikationen}

Formålet med projektet er at beskrive de nordiske landes indsats for at fremme miljøeffektiv teknologi som løsning på miljøproblemer og at komme med forslag til forbedringer i indsatsen. Dette gøres ved at analysere en række parametre for indsatsen i de forskellige lande. Formålet er også at finde særlige nordiske muligheder for samarbejde landene imellem inden for arbejdet med miljøeffektiv teknologi, herunder også at finde muligheder for samarbejdet i de nordiske institutioner. Hvis der sker en tilstrækkelig detaljeret og handlingsorienteret beskrivelse af de enkelte landes indsatser, vil det være projektets idé, at mulighederne for inspiration mellem landene vil kunne øges.

\subsubsection{Definition af miljøeffektiv teknologi}

Over de sidste 20 år har flere forskellige termer været anvendt, som dækker nogenlunde samme mening eller kun afviger lidt fra forståelsen af miljøeffektiv teknologi. Denne forskellige anvendelse af begreber skyldes forskellige sammenhænge, initiativer etc. De begreber, der har været nævnt oftest har været renere teknologi, renere produkter, grøn teknologi, miljøinnovation, miljøteknologi, miljøteknik, miljøvenlig teknologi, clean technology, ren teknologi, eco-efficient technology, miljøeffektiv teknologi, eco-innovation, environmental technology etc.

I ETAP definerer EU-kommissionen miljøeffektiv teknologi ligesom miljøteknologi til at omfatte produkter, processer og tjenester, som giver tydelige miljøfordele i forhold til eksisterende eller alternative løsninger, set i et livscyklusperspektiv. Miljøeffektive teknologier er teknologier, der direkte eller indirekte forbedrer miljøet. Det kan både være rensningsteknologier, mere miljøvenlige produkter, processer og teknologiske systemer samt mere effektiv håndtering af ressourcer. ${ }^{4}$

OECD/Eurostat har defineret miljøindustri som „all activities which produce goods and services to measure, prevent, limit, minimise or correct environmental damage to water, air and soil, as well as problems related to waste, noise and ecosystems. ${ }^{\text {" }}$

Clean tech-begrebet er en definition, som er hentet fra amerikansk sprogbrug, idet man i USA bruger begrebet clean tech industry nærmest synonymt med den måde man i Europa bruger miljøeffektiv teknologi. Så det handler meget om, hvem man henvender sig til. Virksomheder, som er

\footnotetext{
${ }^{4}$ Commission of the European Communities: Communication from the Commission to the Council and the European Parliament: Stimulating Technologies for Sustainable Development: An Environmental Technologies Action Plan for the European Union, Brussels 28 January 2004, 40 sider.

5 OECD and Eurostat: The environmental goods and services industry - manual for data collection and analysis, 1999.
} 
meget internationalt orienterede, vil gerne bruge clean tech eller clean technology, ligesom investeringsfirmaer også gerne vil bruge dette begreb.

Miljøteknologi kan på nogle virke som en noget gammeldags betegnelse for typiske renseteknologier, men det anvendes også af mange i en langt bredere forståelse. Miljøeffektiv teknologi er efter dette projekts opfattelse det bedste begreb, fordi hele klima- og energisiden uden tvivl også medtages. Klima- og energisiden har ellers en tendens til at afvise begrebet miljøteknologi, idet det virker for snævert og for miljørelateret.

Dette projekt anvender begrebet miljøeffektiv teknologi, som sit centrale begreb, idet det virker som det mest operationelle og et bredtfavnende begreb. Og samtidig bruges EU-Kommissionens definition, i og med at medlemslandene er tilknyttet arbejdet i ETAP under en eller anden form og må forventes at kende denne tilgang. Det sker dog, at miljøteknologi eller clean tech bruges i projektet, men så har det samme mening som miljøeffektiv teknologi.

\subsubsection{EU's indsats for miljøeffektiv teknologi}

Arbejdet med miljøeffektiv teknologi begyndte i EU-Kommissionen i 2001. Det var tæt forbundet med EU's strategi for bæredygtig udvikling, idet denne strategi taler om udvikling og vækst uden at skade miljøet. I marts 2002 udgav EU-Kommissionen en rapport om miljøteknologi for bæredygtig udvikling, som redegjorde for et forarbejde for en indsats fra fællesskabets side. ${ }^{6}$ Det Europæiske Råd bestilte i oktober 2003 en handlingsplan for miljøteknologi, og den 28. januar 2004 vedtog EUKommissionen Handlingsplanen for Miljøteknologi. ${ }^{7}$ Handlingsplanen blev vedtaget af Rådet i marts 2004 .

Handlingsplanen for fremme af miljøteknologi (ETAP) består både af selvstændige initiativer og er en overordnet ramme for at påvirke andre allerede igangværende initiativer til at fokusere på mere miljøteknologi. Handlingsplanen fokuserer på 3 hovedtemaer: fra forskning til marked, forbedrede markedsforhold og global handling.

Temaet om „fra forskning til marked“ handler fortrinsvis om at sikre finansieringsmuligheder. Først og fremmest skal EU's egne forskningsog demonstrationsmidler hjælpe miljøteknologien fremad. Og medlemslandene foreslås at gøre det samme. Hertil etableres en række teknologiske platforme for at få forskere og virksomheder til at samarbejde bedre. Kommissionen har også igangsat en proces om at etablere et fælles verifikationssystem for nye miljøteknologier for at få en mere troværdig introduktion og sikkerhed om anvendelse af de nye teknologier.

\footnotetext{
${ }^{6}$ Commission of the European Communities: Report from the Commission: Environmental technology for sustainable development, Brussels 13.03.2002, 23 sider.

${ }^{7}$ Se note ovenfor.
} 
Det andet tema om „forbedrede markedsforhold“ går ud på at skabe bedre efterspørgsel efter miljøteknologiske løsninger. De forskellige miljøkrav eller -standarder, som fællesskabet fastsætter i forskellig regi, har en betydelig effekt på efterspørgslen efter miljøteknologiske løsninger. Indsatsen skal fokusere på at gøre denne efterspørgsel bedre. Hertil handler det også om at give input til arbejdet med grønne indkøb, oplysning og information til virksomheder.

Det sidste tema om „global handling“ sætter indsatsen ind i en global sammenhæng og har fokus på eksport og fremtidige vækstmarkeder.

Kommissionen sætter med ETAP gang i en proces, hvor Kommissionen selv påtager sig en række forpligtelser og samtidig opfordrer medlemslandene til at gøre ligeså. Man opretter også en fælles arbejdsgruppe af folk fra medlemslandene, som skal holde jævnlige møder, ETAP High Level Working Group (HLWG). På disse møder forsøger man at drive idéen om at fremme miljøteknologi fremad. Der laves et netbaseret nyhedsbrev, som fortæller om indsatsen.

Der udarbejdes også vurderinger af fremdriften i arbejdet med ETAP. Disse rapporter og bilagene hertil giver god information om, hvordan det går. Der er rapporter fra 2005 og 2007, samt bilag hertil. ${ }^{8}$ Der er lavet mere materiale, men ikke alt materiale er offentliggjort. ETAP er blevet kritiseret for at gøre alt for lidt for at forbedre efterspørgslen efter miljøteknologi, og det synes som selve ETAP aktiviteterne efterhånden er ved sande til. I hvert fald hvis man vurderer efter de nyheder som meldes ud via Kommissionen. Der har ikke været en egentlig evaluering af ETAP-aktiviteterne.

Det blev også besluttet, at medlemslandene skulle udarbejde ETAP roadmaps om, hvilken indsats de hver især gjorde. Der foreligger roadmaps for Danmark, Finland, Norge og Sverige, men ikke for Island. Danmarks roadmap er en oversættelse af den danske handlingsplan for miljøeffektiv teknologi. Landenes roadmaps er forældede, fordi de ikke er opdaterede i forhold til de tidspunkter, hvor de blev udarbejdet. Sveriges er den nyeste rapport udarbejdet i 2008.

I EU's budget for forskning og udvikling sættes der til stadighed flere midler af til miljøeffektiv teknologi. Dette er gjort indenfor for EU's 7. rammeprogram for forskning og teknologisk udvikling $(53,2$ mia. EUR i perioden 2007-2013) og EU's rammeprogram for konkurrenceevne og innovation, også kaldet CIP (EU's Competitiveness and Innovation Programme). Specielt CIP har været anvendt til at fremme miljøteknologi, fortrinsvis i små og mellemstore virksomheder. Det er ikke ligetil at verificere, hvor meget EU har bevilget i tilskud, lån etc. til at fremme miljøteknologi i fællesskabet, idet det ikke opgøres.

${ }^{8}$ CEC: Report on the implementation of ETAP in 2004, januar 2005, 6 sider, og CEC: Report of the ETAP (2005-06), maj 2007, 13 sider. 
OECD har udarbejdet en analyse af ETAP Roadmaps for de enkelte lande. ${ }^{9}$ Formålet er at vurdere, hvad hvert enkelt land gør i relation til dets eco-innovations potentiale. OECD studier er stort set altid interessante, men analysen er meget overordnet og giver ikke megen kvalitativt viden om, hvad der sker i de enkelte lande.

I forbindelse med arbejdet med ETAP blev der oprettet et EcoInnovation Observatory (EIO) med det formål at indsamle viden om miljøeffektiv teknologi. Det er en slags konsulentdreven enhed, som skal tilvejebringe mere information om miljøeffektiv teknologi. I EIO deltager en række meget kendte teknologi institutter eller firmaer i Europa finansieret af EU-Kommissionen over 3 år. Der er produceret en årsrapport for 2010, en metoderapport, og landerapporter for de 27 medlemmer af fællesskabet.

The Eco-Innovation Challenge: Pathways to a resource-efficient Europe, Annual Report 2010, beskriver miljøeffektiv teknologi under overskriften eco-innovation og bruger indgangen via resourceeffektivitet og materialer. ${ }^{10}$ Man har valgt indgangen om resourceeffektivitet og materialer for at bringe fokus tættere på arbejdet med bæredygtig udvikling. Måske er det også forskning- og erhvervstilgangens krav til, at miljøsiden ikke må overtage deres dagsorden, der får fokus til at blive lagt på materialevinklen.

I den årlige rapport fra $2010 \mathrm{er}$ der som noget centralt præsenteret the Eco-Innovation Scoreboard, et scoresystem, som giver karakterer til de enkelte lande i Europa. Scoresystemets formål er at vise, hvor det går fremad, og hvad tendenserne er i de enkelte lande. Det består af 13 indikatorer, som er vægtet lige i en samlet vurdering af de enkelte lande. De 13 indikatorer består af interessante informationer om eco-innovation inputs, eco-innovation activities, environmental outcomes, eco-innovation outputs, socio-economic outcomes. Bl.a. kan mere konkret nævnes: 1) samlet støtte i landet til eco-innovation, 2) samlet antal forskere og analytikere af det samlede antal beskæftigede, 3) en række produktivitetsfaktorer for energi, vand, materialer, klimagasser relateret til bruttonationalproduktet, 4) eco-innovations patenter, 5) beskæftigelse i eco-innovations industrien, 6) størrelsen af eco-innovation markedet, 7) eksporten af ecoinnovation og 8) EMAS-registrerede organisationer.

For de nordiske lande er det meget interessant, at Finland scorer højest af alle lande med 157 point, Danmark er nr. 2 med en score på 155 point, og Sverige er nr. 5 med en score på 128. Disse 3 lande er sammen med Tyskland og Østrig i et klart førerfelt i EU, hvor gennemsnittet for

\footnotetext{
9 OECD Report: Assessment of ETAP roadmaps with regard to their eco-innovation potential, 2010 (December 2009), 176 sider.

${ }^{10}$ Eco-Innovation Observatory: The Eco-Innovation Challenge, Pathways to a resource-effective Europe, Annual Report 2010, May 2011, 110 sider.
} 
EU-landene scoringsmæssigt er sat til 100 point. Norge og Island er ikke medtaget og dermed ikke vurderet. Generelt må man vurdere scoresystemet og dets evne til at beskrive de enkelte lande meget perspektivrigt. Det er vel nok et af de bedste forsøg på at give karakterer landene imellem og tilmed koble eco-innovation til miljøoutput. Man må imidlertid også forstå, at der ofte er tale om særdeles aggregerede data, som så ikke helt giver en detaljeret forståelse af, hvad der egentligt sker på landeniveau. Det er f.eks. ekstremt vanskeligt at opgøre alle disse enkelte data. Eksportparameteren er et eksempel på data, som er vanskelige at opgøre. Eller det må f.eks. også være berettiget at drage en vis tvivl om værdien af antallet af EMAS-registerede, idet disse i enkelte lande viser tilbagegang. Det havde været bedre at tage ISO-registreringer med også. Andre tal er forhåbentlig mere overbevisende som f.eks. tallene om miljøoutputs i form af produktivitetsfaktorerne.

Til støtte for analysen er der udarbejdet et landestudium for hvert enkelt af landene. ${ }^{11}$ Dermed er der en interessant rapport for Finland, Danmark og Sverige med mange værdifulde detaljer. Igen er dataene meget aggregerede og lader læseren usikker på muligheden for at kontrollere validiteten af data. Ikke desto mindre er samme metode anvendt ved de forskellige lande, så sammenligneligheden må være rimelig god eller noget af det bedste man kan opnå. Ved en gennemgang af f.eks. Danmark, viser der sig dog en række graverende fejl, som ikke lader sig forklare. Hele klima- og energiteknologisiden er for Danmarks vedkommende undervurderet, idet traditionelle miljøteknologiske områder som vand, luft og affald er overvurderede. En række gode eksempler på firmaer og perspektivrige områder er også nævnt i de enkelte landerapporter.

Der er også fra EIO udgivet en Methodological Report, som beskriver arbejdsgrundlaget og definerer termer, som EIO bruger. ${ }^{12}$ Rapporten kan bruges i forsøg på at finde metodemæssige veje til afklaring inden for eco-innovation.

EU Kommissionen udgav i september 2011 en køreplan til et ressourceeffektivt Europa. ${ }^{13}$ Denne køreplan opstiller en vision om, hvad der skal gøres inden 2020 for at nå en række ressourceeffektive mål. Som sådan er dokumentet meget positiv læsning, hvis man ønsker, at Europa skal gennemføre en stærk ressourceeffektiv indsats. Der skal tages rigtig mange intiativer både af Kommissionen selv, men også af medlemslandene. Spørgsmålet er så om disse tiltag kan gennemføres politisk, især i en situation, hvor økonomien har det dårligt. Der er mange eksempler på tidligere

\footnotetext{
${ }^{11}$ Eco-Innovation Observatory: EIO country brief 2010: Denmark, Finland, og Sweden, ca. 17 sider hver. 12 Eco-Innovation Observatory: Methodological Report, Autumn 2010, 104 sider.

${ }^{13}$ Europa Kommissionen: Meddelelse fra Kommissionen til Europa-Parlamentet, Rådet, Det europæiske $ø$ konomiske og sociale udvalg og Regionsudvalget: Kørepan til et ressourceeffektivt Europa, 20. september 2011, 25 sider.
} 
meget positive udmeldinger, der ikke har ført til så meget. Man har dog lov til at håbe, at denne køreplan vil gøre en forskel.

EU Kommissionen har også i december 2011 offentliggjort et udkast til en afløser af ETAP. Denne afløser i form at et nyt program skal hedde Eco-innovation handlingsplanen (The Eco-innovation Action Plan), forkortet Eco-AP, og starter med en overskrift med teksten: Innovation for a sustainable Future. ${ }^{14}$ Udkastet er i høring til ca. midten af januar måned 2012. Med Eco-AP ændres sprogbrugen fra eco-efficient technology eller om man vil environmental technology til Eco-innovation, som nu skal være det nye ord som bruges. Eco-innovation er hver innovation, som fører til fremskridt i bæredygtig udvikling ved at reducere påvirkningen af miljøet eller fremme en mere effektiv brug af ressourcer. Ecoinnovations handlingsplanen har 6 nøgle områder:

- Bruge miljøpolitik og lovgivning til at fremme eco-innovation

- Yde tilskud til demonstrationsprojekter og fremme eco-innovations teknologiers vej til markedet

- Udvikle nye standarder til at fremme eco-innovation

- Mobilisere finansieringsinstrumenter og tilskud til små og mellemstore virksomheder

- Fremme internationalt samarbejde

- Yde støtte til udvikling af kompetencer og jobs til hjælp for arbejdsmarkedet

Som en første reaktion på dette udkast til handlingsplan kan man vel sige, at det synes som man gentager en del af ETAP-argumentationen, nu i ny version om eco-innovation. Man kan kun håbe, at EU Kommissionen vil gøre handlingsplanen meget konkret og bidrage så meget som muligt med regulering og tilskud til eco-innovation, samt opfordre medlemslandene til at gøre mere end de har gjort under ETAP.

\subsubsection{Nordiske publikationer og samarbejde}

I det nordisk samarbejde har Nordisk Ministerråd udgiver flere publikationer om miljøteknologi, miljøeffektiv teknologi eller grøn vækst.

Man kan nævne en publikation fra 2006 om Nordic Environmental Technology. ${ }^{15}$ Det lille hæfte med nordiske eksempler på miljøteknologi skal vise eksempler på miljøteknologi til at sikre økonomisk vækst og samtidig sikre en beskyttelse af miljøet. Der er en konkret beskrivelse af

\footnotetext{
14 European Commission: Communication from the Commission to the European Parliament, The Council, The European economic and social committee of the regions: Innovation for a sustainable Future - the Ecoinnovation Action Plan (Eco-AP), udkast fra december 2011, 20 sider.

15 Norden: Nordic Environmental Technology, TemaNord 2006:701, 20 sider.
} 
3 områder: 1) innovativ skibsteknologi, 2) energieffektive og miljøvenlige bygninger, og 3) biologisk innovation. Hvert af områderne har 3 konkrete eksempler. Dette er interessant i sig selv, men løfter heller ikke diskussionen over det gode eksempel. Det må vel siges at være den letteste form for information at fortælle det gode eksempel. Man kan tilmed efterspørge flere af disse fortællinger om gode eksempler, hvor virksomheder har udviklet eller opfundet teknologi. Det kan være lærerigt at læse om eksemplerne.

En anden væsentlig nordisk rapport er Innovation Systems and Environmental Technologies, som blev udgivet i $2008 .{ }^{16}$ Nordisk Ministerråd gennemførte i 2006-07 et 2 årsprojekt om Green Market and Clean Technologies - Leading Nordic Innovation and Technological Potential for Future Markets. Formålet med studiet var at analysere, hvordan man kan udvikle og sprede miljøeffektive teknologier ved at studere gennemførte analyser og selv gennemføre specifikke empiriske studier. Rapporten gennemgår en del teori om innovationer og taler om innovationssystemer. Den beskriver teknologi „push“ og markeds „pull“, som de to yderpunkter i en forklaring på, hvorfor innovationer sker. Der er gennemført 3 empiriske studier af teknologiområder: 1) byggeindustrien, 2) papirindustri (pulp and paper) og 3) mobiltelefon sektoren. For hvert af disse 3 områder er der lavet et studie, som Nordisk Ministerråd også har udgivet. På baggrund af disse studier gives vurderinger af, hvad der skal til for at fremme innovation: f.eks. viden, human ressources, privat og offentlig finansiering, og markedsforhold. Rapporten kobler sig også til EU's strategi for ETAP og giver nogle anbefalinger på, hvad der kan gøres.

Som opfølgning på analysearbejdet med Green Market and Clean Technologies blev der afholdt en konference med 70 deltagere i september 2008 om Environmental Technology and Innovation - Drivers and Policy Measures. Der er lavet en rapport fra konferencen. ${ }^{17}$

En række anbefalinger er fremhævet. Det er gode anbefalinger, men man må også sige, at de er ikke overraskende. På konferencen blev der også holdt to indlæg, som havde stor relevans til temaet, men som ikke umiddelbart var en del af det store projekt: 1) om myndighedernes muligheder for at påvirke Ecodesign og 2) Teknologiske udbud (procurement).

I løbet af 2010 førte man i det nordiske samarbejde en drøftelse om, hvordan man i nordisk regi kunne bidrage til grøn vækst. Man lavede en rapport om Greening the Economy: Nordic experiences and challenges, som var færdig i januar $2011 .^{18}$ Denne rapport er en grundig gennem-

\footnotetext{
${ }^{16}$ Norden: Innovation Systems and Environmental Technologies, TemaNord 2008:565, 80 sider

17 Norden: Environmental Technology and Innovation - Drivers and Policy Measures, Summary notes from the NMRIPP Conference, Copenhagen, 2-3 september 2008, januar 2009, 44 sider.

${ }^{18}$ Nordisk Ministerråd: Greening the Economy: Nordic experiences and challenges, „Synthesis report“, udført af Vista Analyse, den 31. January 2011, 121 sider.
} 
gang af, hvad de nordiske lande har gjort siden 1970'erne med hensyn til miljøregulering, især anvendelsen af økonomiske styringsmidler, samt beskrivelse af vækstudviklingen i de nordiske lande. Rapporten er grundig. Den dækker bredt og på udmærket vis den udvikling, der har været $\mathrm{i}$ de nordiske lande. Den bygger primært på nordisk materiale udarbejdet af Nordisk Ministerråd, temanordrapporter og OECD for overordnede analytiske studier af temaet, samt enkelte studier om de nordiske lande. Som rapporten fortolker grøn vækst, er det mere en indirekte funktion af miljøreguleringen og økonomiske styringsmidler, og hvad man har opnået i økonomisk udvikling, end bevidste handlinger for at drive grøn vækst fremad. Denne erkendelse er først blevet virkelig som led i finanskrisen og overvejelser om at fremme grøn vækst.

Der er også i rapporten et særligt kapitel (nr. 5) om Innovation in green technologies - some cases. Efter en gennemgang af de nordiske landes energisystemer, som det vigtigste grundlag for innovation, beskrives en række cases, som i udpræget grad er gentagelser af den tidligere nævnte publikation om Nordic Environmental Technology og rapporten om Innovation Systems and Environmental Technologies. Eksemplerne er udmærkede og inspirerende som viden om, hvad der konkret er sket i flere eksempler.

Man kan kritisere rapporten for at være for fokuseret på økonomiske styringsmidler som instrument. Dette meldes dog også eksplicit ud og må anses som den klassiske økonomiske tilgang til temaet om udvikling af miljøeffektiv teknologi. Administrative instrumenter vurderes ikke nær så højt som virkemidler. Der er dog mange reguleringssituationer, hvor administrative instrumenter har virket udmærket i fremme af miljøeffektiv teknologi. Rapporten synes dog heller ikke at bekymre sig om de mange situationer, hvor økonomiske styringsmidler er skruet dårligt sammen, mangler opdatering etc.

Man kan også fremhæve de noget traditionelle synspunkter på subsidier, som rapporten deler med mange andre økonomer og ikke mindst OECD's udmeldinger. Her ses subsidier generelt som uhensigtsmæssig statsstøtte, og det anbefales kun at satse på forskning og udvikling. Denne tilgang afskærer imidlertid et stærkt instrument, som ofte synes at sætte sig mellem forskning og udvikling og markedsføring, nemlig tilskud til demonstrationsanlæg for at få afprøvet en bestemt teknologi i fuldskala til endelig markedsintroduktion. Den foreliggende rapport om de nordiske landes indsats for miljøeffektive teknologier vil argumentere for, at der ofte mangler tilstrækkelige midler til introduktion af fuldskalaanlæg. Naturligvis bør man også drøfte værdien af mere generelle subsidier til fremme af særlige teknologier. Det er naturligvis klogt, at disse gøres tidsbegrænsede. 
Nordisk Ministerråd arrangerede i juni 2011 en workshop om grøn $ø$ konomi, hvor man drøftede en række temaer og forsøgte at give anbefalinger til det videre arbejde for disse temaer. ${ }^{19}$

Fra det nordiske arbejde kan man også nævne det arbejde, som udføres af Nordic Innovation Centre, et center beliggende i Oslo med ca. 20 ansatte. Nordic Innovation Center har prisværdigt arbejdet med netværkssamarbejde på området for miljøteknologi. Der er udgivet 2 rapporter, som skal nævnes, idet det giver et entydigt løft til arbejdet med at fremme netværk. ${ }^{20}$ Det synes ikke som om centeret har lavet mere arbejde på området end dette netværksamarbejde. Det kan måske undre, hvis dette er en korrekt observation.

Nordisk Ministerråd har gjort ganske meget inden for området grønne offentlige indkøb eller teknologiske udbud (green procurement og technology procurement), nok under indtryk af den succes man har haft i Sverige på området. I 2009 udgav man en lille publikation om grønne offentlige indkøb med nogle få eksempler som illustration og med nogle retningslinier for at gøre det bedre i de offentlige indkøb. ${ }^{21}$

Den væsentligste publikation vedr. grønne offentlige indkøb/udbud (procurement) er rapporten Benefits of Green Public Procurement. ${ }^{22}$ I denne publikation vælges 3 områder, som har væsentlige miljøpåvirkninger: Taxi- og bustrafik, computere og relaterede ydelser, samt reng $\emptyset$ ringsmidler. Rapporten anbefaler grønne offentlige indkøb/udbud på de 3 områder som et blødere og mere dynamisk styringsmiddel, som i de nordiske lande har vist sin styrke.

Nordisk Energiforskning (NEF) er en institution inden for Nordisk Ministerråd. NEF finansierer en række projekter til forskning og udvikling. Strategien for 2011-2014 hedder Bridging sustainable solutions og bygger videre på institutionens rolle som netværksbygger i Norden og mellem de nordiske lande. NEF udbød i efteråret 2010100 mio. NOK til forskning inden for bæredygtige energisystemer år 2050. Der er udvalgt 10 projekter, heraf 2 industriprojekter. Projekterne spænder fra systemanalyse til sol-, vind- og biomasseprojekter.

Man bør også nævne det nordiske Topforskningsinitiativ (TFI) om klimaforhold og klimateknologi, hvor der er støttemidler til 375 mio. DKK, dels fra Nordisk Ministerråd og dets institutioner, men også fra

\footnotetext{
${ }^{19}$ Nordisk Ministerråd: Miljösektorns workshop om grön ekonomi, 10. Juni 2011, workshopmateriale og overheads etc.

20 Nordic Innovation Center: Nettverksamarbeid i Norden for eksport av miljøteknologi (Forprosjekt), maj 2006, 32 sider, og Nordic Innovation Center: Nordic Environmental Technology Solutions (NETS) - Commercialization of key business sectors, november 2008, 37 sider.

${ }^{21}$ Norden: Green procurement makes a difference! Prime examples from the Nordic countries, 2009, 24 sider 22 Norden: Benefits of Green Public Procurement, TemaNord 2009:593, 63 sider, udført af Bjørn Bauer, Jens Christensen, Karen Christensen, Tue Dyekjær-Hansen, and Ida Bode.
} 
nationale nordiske midler. Der er tale om et 5-årigt initiativ til at fremme forskning på klimaområdet.

Der blev også udarbejdet en publikation om Innovative Green Public Procurement of Construction, IT and Transport Services in Nordic countries. ${ }^{23}$ Der bruges en ret bred tilgang til grønne indkøb/udbud og teknologiske udbud for at vise bredden i virkemidler. Rapporten beskriver situationen i 3 sektorer med eksempler og kommer med en række anbefalinger på, hvordan de nordiske lande kan gøre det bedre.

Man bør også nævne en rapport om the Nordic CleanTechmarket Survey. ${ }^{24}$ Denne analyse er en undersøgelse af, hvad de nordiske kommuner gør for at fremme markedet for miljøeffektiv teknologi. Et af hovedresultaterne er, at der mangler viden i kommuner om nye miljøvenlige løsninger.

Endelig bør man nævne en nordisk rapport om Kundskap för grön tillväxt, som beskæftiger sig med grøn vækst i et perspektiv set fra uddannelses-, forsknings- og innovationsvinklen. ${ }^{25}$ De nordiske lande er hver især blevet analyseret for aktiviteter om grøn vækst i uddannelses- og forskningssammenhæng. I rapporten beklages, at begrebet grøn vækst synes at være for bredt til at få en klar fokus på området. Der gives en række anbefalinger i rapporten til kommunikation og samarbejdsmuligheder. Rapporten er interessant, fordi den analyserer en sektor, uddannelse og forskning med udgangspunkt i grøn vækst, for at finde omdrejningspunkter. Imidlertid synes rapporten at være ret snæver i sin tilgang, i og med at den synes at forudsætte at øget højere uddannelse nok er en af de vigtigste forudsætninger for grøn vækst. Denne forudsætning kan givetvis begrænse anvendelsen af rapporten, som dog er en udmærket tilgang til, hvad der er gjort i de enkelte lande på området.

Det nordiske samarbejde fremviser en række interessante rapporter og initiativer. Der synes ikke at være en klar linje i, hvor man vil hen med det nordiske samarbejde. Man må konstatere, at der ikke er meget samarbejde mellem forskellige aktører i nordisk regi. Man kunne godt i nordisk regi overveje, hvordan man bedst kan støtte miljøeffektiv teknologi eller miljøteknologi, som elementer af grøn vækst.

\footnotetext{
23 Norden: Innovative Green Public Procurement of Construction, IT and Transport Services in Nordic countries, udarbejdet af Planmiljø, december 2009, TemaNord:2009529, 103 sider.

24 Norden: The CleanTechMarket Survey, TemaNord 2010:591, 39 sider.

${ }^{25}$ Norden: Kundskap för grön tillväxt. Huvudrap port om arbetet för grön tillväxt ur ett utbildnings-, forsknings- och innovationsperspektiv, december 2011, TemaNord 2011:552, udført af Sweco Eurofutures, 92 sider, samt en Delrapport 2 om aktiviteter vid de nordiska tekniska högskoler och universitet, udført af Nordtek, 51 sider.
} 


\subsubsection{Kobling til Bæredygtig Udvikling}

Man bør nævne det store arbejde for bæredygtig udvikling, som især blev gennemført omkring år 2000. Bæredygtig udvikling var og er utrolig vigtig i en samfundsmæssig udvikling, måske mest miljøområdet. Det nordiske samarbejde har været banebrydende for arbejdet med bæredygtig udvikling ligesom de nordiske lande også hver for sig har gjort en betydelig indsats. Man bør fremhæve Nordens satsning på hållbar eller bæredygtig udvikling, som startede i år 2000. Nu har vi i nordisk regi den 3. nordiske strategi (2009-2012) for hållbar eller bæredygtig udvikling. Meget positivt er sket i dette regi, men man må også erkende, at dynamikken svækkes noget, i og med at bæredygtig udvikling bliver summen af allerede besluttede initiativer og sjældent skaber nyt i sig selv. Beslutninger træffes i regi af enkelttemaer og ikke samlet i en tilgang for bæredygtig udvikling. Det lykkes dermed ikke bæredygtig udvikling som strategi at løfte et lands indsats for en mere miljømæssig fornuftig udvikling. Det gøres bedst i form af enkelttemaer, som nu f.eks. klimatemaet, hvor enkelte lande har besluttet at udfase brugen af fossile brændstoffer, om end denne beslutning har et meget langt tidsmæssigt sigte. Bæredygtig udvikling er ved at blive umoderne, mens grøn vækst er moderne.

\subsubsection{Kobling til Grøn Vækst}

Når man analyserer, hvordan miljøeffektiv teknologi eller ecoinnovation kan løse miljøproblemer ses tydeligt, at koblingen til vækst bliver vigtig. Dette kaldes grøn vækst og signalerer samfundets satsning på miljømæssige positive sider af væksten eller det at satse på miljømæssigt positive faktorer til fremme af vækst.

Med finanskrisen er der i stigende grad fokuseret internationalt på globalisering, vækst og arbejdspladser, i og med at de fleste lande oplevede betydelig nedgang i deres økonomiske formåen. Grøn vækst er i denne forbindelse blevet ekstra interessant, måske nok fordi klimakrisen også spiller ind og stiller meget kontante krav til de enkelte lande om at ændre væsentlige dele af de økonomiske forhold, som f.eks. brugen af fossile brændstoffer. Flere forskellige lande har ønsket at finde nye vækstparametre til at komme ud af krisen. Grøn vækst har i denne forbindelse fået en særlig styrke som erhvervsstrategi. Mange lande sætter ekstra økonomiske midler af til grøn vækst eller miljøeffektiv teknologi, med en særlig fokus på det vigtige område for klima- og energiteknologi. Miljødimensionen har dog undertiden vanskeligt ved at trænge igennem som et reelt perspektivrigt pejlemærke i denne proces, i og med at det ofte bliver trængt i baggrunden af synspunkter om vækst og eksport.

Grøn vækst må siges at være den overordnede ramme for øgning af væksten ved hjælp af miljødimensionen, mens miljøeffektiv teknologi er ét til grøn vækst underordnet styringsmiddel i form af udvikling af tek- 
nologi. Grøn vækst trækker på mange forskellige parametre til at øge væksten, mens miljøeffektiv teknologi tager udgangspunkt i den enkelte teknologiske løsning og ser på mulighederne for at fremme denne løsning. Dette projekt ønsker at fokusere på udviklingen af miljøeffektiv teknologi og ikke på grøn vækst.

Det er dog værd at nævne det store arbejde som gøres internationalt for at fremme grøn vækst. EU-Kommissionen har udgivet en langsigtet vækststrategi, Europa 2020, som har betydelige elementer af grøn vækst i sig. ${ }^{26}$ Der fokuseres på ressourcesiden af væksten og især i forhold til klima, energi og mobilitet. Ressourceeffektivitet og innovation er de centrale temaer.

OECD har arbejdet med grøn vækst siden medlemslandene i juni 2009 bad OECD om at udarbejde en strategi for grøn vækst. Først udgav man en midtvejsrapport i maj 2010 og i maj 2011 kom den endelige rapport. ${ }^{27}$ Der er produceret et kvalitetsprodukt fra OECD, som næsten altid med OECD's arbejde. Rapporten er næsten for tung, men så er der lavet en kort sammenskrivning for politiske beslutningstagere og ikke mindst et notat om instrumenter på 25 sider. Dette instrumentnotat gennemgår - ganske vist - set fra et overordnet plan en række områder, som der bør ageres på, hvis et land ønsker elementer af grøn vækst. Man kan nævne følgende temaer:

- Lav en diagnose af et lands forhold

- Etabler effektive institutionelle forhold, f.eks. i statslig regi

- Lav politikpakker på udvalgte områder

- Eksisterende programmer bør evalueres og evt. reformeres

- Innovation skal fremmes

- Vær opmærksom på forbrugeradfærd

- Styrke finansieringsforhold, både offentlig, men også synergier til det private område

På en måde er denne strategi en manual og så alligevel ikke. OECD har den holdning, at nationale forhold vil bestemme instrumenter og tiltag. Det indebærer, at hvert enkelt land må lave sin egen grønne vækststrategi skruet sammen efter nationale omstændigheder, og hvad det pågældende land allerede har gjort i form af grønne tiltag. Det siger sig selv, at de nordiske lande, som allerede er nået et stykke vej i anvendelsen af de enkelte instrumenter, skal bruge en anden tilgang end nye vækstlande og decide-

\footnotetext{
${ }^{26}$ EU-Kommissionen: Europa 2020, En strategi for intelligent, bæredygtig og inklusiv vækst, marts 2010 27 OECD: Declaration on Green Growth, juni 2009, OECD: Interim report on the Green Growth Strategy. Implementing our commitment for a sustainable future, maj 2010, og OECD: Towards Green Growth, maj 2011, 144 sider, samt hertil Summary for policy makers, og ikke mindst Tools for delivering on Green Growth, 25 sider.
} 
rede udviklingslande. Som sådan er OECD’s arbejde meget mere direkte end EU's langsigtede vækststrategi, men naturligvis kun vejledende i sin form. OECD fortsætter sit arbejde med grøn vækst.

Man bør også lige nævne UNEP's arbejde om et grønt økonomisk initiativ, som startede i oktober 2008. UNEP har i februar 2011 udgivet sin rapport om Grøn Økonomi. ${ }^{28}$ UNEP’s arbejde er i overvejende grad rettet mod udviklingslandene.

\subsubsection{Rapportens indhold}

Med afsæt i en afdækning af de nordiske landes indsats for at fremme miljøeffektiv teknologi, vil indsatsen i de enkelte nordiske lande blive gennemgået i rapporten. De enkelte nordiske landes arbejde med miljøeffektiv teknologi belyses for så vidt angår organisation, forskellige fonde, ressourcer i form af mandskab og tilskudsmidler, indsatsområder, miljøvinkel, analyser, succeser og om muligt fiaskoer. Herved etableres en mulighed for sammenligning af, hvad der sker i de enkelte nordiske lande, om end forudsætninger i de forskellige nordiske lande varierer betydeligt.

Som en parallel til en sådan gennemgang kan nævnes analyser af det nordiske samarbejde om økonomiske styringsmidler, hvor statusbeskrivelser skildrer de enkelte landes indsats, og hvor der sker påvirkning mellem de enkelte landes indsats. Koordinering af nordisk samarbejde om miljøstøtte til Østeuropa kan også nævnes som en parallel, hvor der var eksempler på en dynamisk arbejdsdeling på flere områder.

Kerneanalysen går ud på at gennemgå de enkelte nordiske landes indsats for miljøeffektiv teknologi med særlig vægt på udvalgte parametre. For hvert af de nordiske lande: Danmark, Finland, Norge og Sverige gennemgås denne indsats. EU's handlingsplan ETAP med start i 2004 har de fleste europæiske lande med, og der er udarbejdet landeprofiler, om end disse er delvist forældede. Island kobles på, selv om man ikke deltager i ETAP, men viden kan tilvejebringes, hvis Island selv gør en ekstra indsats for at hjælpe med at tilvejebringe viden.

De parametre, som der lægges særlig vægt på er:

- Organisation

- Antallet af ansatte, som arbejder med miljøeffektiv teknologi, som en særlig indsats

- Tilskudsmidler, som er afsat fra statslig side, og forskellige fondskonstruktioner

- Indsatsområder

28 UNEP: Towards a Green Economy: Pathways to sustainable development and poverty eradication, februar 2011, 626 sider, samt Summary of conclusions og Sunthesis for policy makers. 
- Udbudssiden, dvs. teknologistøtte

- Efterspørgselssiden, dvs. regler mv.

- Særlige miljøvinkler og miljøvægtning

- Særlige teknologiområder

- Særlige analyser

- Succeser udpeget af landene

- Evt. fiaskoer udpeget af landene

- Eksport som en parameter i indsatsen

- Aktiviteter, som iværksættes af andre (f.eks. organisationer, kommuner eller virksomheder) end den pågældende regering

Indholdet vil være en konkret gennemgang af de enkelte landes aktiviteter for at fremme miljøeffektiv teknologi med særlig vægt på miljøaspekterne. Af denne gennemgang kan der drages en række konklusioner om, hvad der virker bedst og hvor, der er satset fremtidsorienteret. Det vil udelukkende være et internt studie af de nordiske nationale aktiviteter, mens internationale aktiviteter kun berøres marginalt. Dog medtages eksportparameteren, fordi den ser ud til at være vigtig for at fremme forståelsen af aktiviteterne i hjemlandet.

Projektet vil arbejde med en præmis om, at der er et meget stort potentiale i en systematisk udnyttelse af forskellige håndtag som tilskud, afgifter, regulering til at fremme miljømæssige løsninger i form af miljøeffektiv teknologi. Præmissen bygger på erfaring fra mange konkrete eksempler på miljøeffektiv teknologi. Dette givet, vil det være en interessant opgave i sig selv at undersøge de nordiske landes indsats på feltet ved at gå i dybden i forhold til mere formelle udmeldinger og stille en række dybdeborende spørgsmål. Hvordan skabes løsninger?, hvordan overkommes barrierer?, hvad er strategien i enkelte tiltag?, politikernes rolle? etc.

Det konkrete vil naturligvis også beskæftige sig med enkelte indsatsområder. Det mest oplagte område eller eksempel at nævne er klima- og energiteknologi, som har tiltrukket sig stor opmærksomhed i de seneste år på grund af klimakrisen. Mange lande satser på forskellige former for vedvarende energi, f.eks. vind, geotermi, sol, vandkraft, biomasse etc. Især målsætninger om at reducere udslippet af klimagasser kraftigt har givet gode vilkår for fremme af klima- og energiteknologi. Man kan også nævne teknologier til rensning af vand og luft, som er 2 betydelige miljøteknologiske områder. Og man kan nævne produkt- og affaldsområdet, hvor reduceringen af forbruget af ressourcer er af stor vigtighed. Der er dog mange eksempler, som kan nævnes, og der må nødvendigvis ske en udvælgelse.

Efterspørgselssiden beskrives sådan som udbudssiden. Efterspørgselssiden vil blive tillagt en betydelig vægt, fordi dette sjældent gøres i studier af miljøeffektiv teknologi. Det er meget vigtigt at belyse, hvad der gøres for at styrke efterspørgslen, i og med at det ikke er velbeskrevet, hvad der præcist gøres i de enkelte situationer. Igen er det naturligvis afhængig af, hvad de enkelte lande egentlig gør og ønsker at oplyse. 
Der vil som sådan være tale om et handlingsorienteret studie, som har til formål at beskrive konkrete handlinger. Studiet vil give en status på, hvordan det centrale niveau/regeringen griber indsatsen an i de enkelte lande. Herefter vil der blive forsøgt at foretage konklusioner på denne baggrund til brug for en fælles forståelse af, hvor langt man er, og hvordan det går. Og endelig vil det blive vurderet om der er muligheder for forbedringer, også i et nærmere samarbejde landene imellem.

Opbygningen af rapporten vil være 5 landeafsnit med en længde alt afhængig af tilgængeligt materiale. Desuden vil der være et længere indledende afsnit med beskrivelse af definitioner, ETAP, metode etc. Og der vil være et afsluttende afsnit om resultater, og hvad man kan sige om sammenligningen af landenes indsatser, samt generelle anbefalinger til det fortsatte arbejde med miljøeffektiv teknologi.

Et landeafsnit vil bestå af en beskrivelse af, hvad der er sket i landet på området i perioden 2004-2010. Dette vil omfatte aktører i det statslige regi, organiseringen mv. Det vil også omfatte de midler, der har været eller er til rådighed i perioden til teknologistøtte. Det vil omfatte opdelingen af midler på teknologiområder og interessante projekter, og det vil indeholde en gennemgang af efterspørgselssiden i form af, hvad staten har gjort for at hjælpe efterspørgslen i gang, f.eks. i form målrettede reguleringstiltag. Der vil blive analyseret på det materiale, som landet selv peger på, som vigtigt og andet materiale, som kan tilvejebringes. Og særlige analyser, som landet har gennemført vil blive beskrevet. Desuden vil succeser blive beskrevet og ligeledes fiaskoer, hvis de oplyses. Eksportparameteren i miljøeffektiv teknologi opgives, hvis landet har et tal og tallet belyses. Hvis andre aktører eller grupper af aktører har vigtige initiativer på området miljøeffektiv teknologi beskrives dette ligeledes. Der tegnes et perspektiv over, hvor landet bevæger sig hen ad samlet set. Hermed kan der skabes en samlet gennemgang af, hvad landet har gjort. Ingen af landene har lavet en sådan gennemgang, som forsøger at sætte proportioner på indsatsen og resultater beskrives sjældent. Typisk er der en række dokumenter, men de har ofte en udpræget fragmentarisk karakter, der gør det vanskeligt at få et helhedsbillede af indsatsen.

\subsubsection{Metodemæssige overvejelser}

Arbejdsgrundlaget vil være det tilgængelige materiale, som er udgivet i de enkelte lande. Dette materiale har givetvis en karakter af at være rimelig overordnet og politikorienteret, i og med at indsatserne først er ved at komme i gang. Typisk er det udgivne materiale også ofte forældet, måske op til 2 år, i forhold til igangværende aktiviteter.

Hertil vil der blive gennemført en spørgeskemaundersøgelse af indsatsen i de 5 lande baseret på nøgleparametrene beskrevet ovenfor med forklaring. I første omgang rettes spørgeskemaerne til miljøministerierne, i og med at miljøeffektiv teknologi i sit udgangspunkt er en miljødagsorden. 
Denne spørgeskemaundersøgelse vil blive fulgt op af kvalitative interviews med nøglepersoner i landene. Det forudsættes, at der i de enkelte nordiske lande er en positiv tilgang til at svare og medvirke. Det kan givetvis gøres meget hurtigt, men der skal være en vis velvilje til at svare, ellers bliver det vanskeligt at få svar og informationer ind. Medmindre andet ønskes af landene, vælges miljøministerierne som indgangsvinkel.

De enkelte landes indsats på forskellige teknologiområder vil i første omgang blive afgjort af, hvad de enkelte lande peger på som indsatsområder. Dermed er det landene selv der via svarene i spørgeskemaerne peger på, hvad de har valgt at satse på. Følgelig vil projektet ikke kun beskæftige sig med klima- og energiteknologi, men beskrive de teknologier, som landene finder interessante at beskæftige sig med. Naturligvis vil andet blive taget med, såfremt der er materiale, som beskriver dette.

Som udgangspunkt og af økonomiske hensyn arbejdes med, at interviewene kan gøres via e-mail eller telefon. Kan dette ikke gennemføres forsvarligt, skal der måske afholdes enkelte møder.

Målet er ikke at lave en traditionel komparativ analyse mellem landene, idet forskellene givetvis er for store. Målet må dog være at opnå en vis grad af sammenlignelighed, især for at vurdere mulige samarbejdsflader.

Der skal bruges nationale vidende folk i et vist omfang for Norge, Sverige og Finland med en lille overvægt på Finland pga. at der af sprogmæssige årsager kan være materiale, som udelukkende er på finsk. Danmark anses at kunne dækkes tilstrækkeligt af forfatteren til oplægget. Island må vurderes særskilt, da man ikke har lavet et såkaldt „road map“ til ETAP. Afsnittet om Island må bygges op særskilt, men en national vidende person fra Island. Miljøministerierne inddrages i hvem der kan vælges som vidende personer. De vidende personer er tænkt som kvalitetssikrere af det skrevne materiale og som diskussionspartnere for løsninger. Konsulenterne fra de enkelte lande skal dermed hjælpe med at finde materiale og konklusioner, samt være behjælpelige med at kvalitetssikre rapporterne. Først når der foreligger et første udkast til rapport om det pågældende land, forventes konsulenterne at rette teksten og skrive til i denne.

Som en vurdering efter projektets gennemførelse har det været nødvendigt at sænke ambitionsniveauet for, hvor mange oplysninger man kan tilvejebringe indenfor en kort tidsperiode. Årsagen hertil er, at der ikke har været tilgængelige informationer i et omfang, som var forventet.

Det ville have været optimalt, hvis hvert land havde en oversigt over tilskudsmidler år for år. Sådanne oversigter foreligger ikke, i hvert fald ikke særligt tilgængelige. Der er tilmed stor forskel på definitionerne af miljø og energi på de tilskudsmidlerne, som opgøres. Derfor er der ikke lavet sådanne oversigter. Det ville ligeledes være optimalt, hvis man havde sådanne tal for hvert land og satte dem i relation til hinanden i forhold til f.eks. indbyggertal eller BNP, forstået naturligvis i en omregnet valutastørrelse, som er direkte sammenlignelig. Det kan måske gøres i fremtiden, hvis der er talmateriale hertil, eller hvis man for den sags 
skyld bruger betydelige ressourcer på at tilvejebringe disse få centrale data. Samlet set må man imidlertid vurdere, at projektet kommer et stykke af vejen ved at beskrive rapporter, strategier etc. og forsøger at give et billede af, hvad der foregår i hvert enkelt land.

Rapport- eller litteraturmaterialet har været bearbejdet af konsulent Karsten Skov, som kun har et indgående kendskab til danske forhold. Af denne grund har det været planlagt muligt i projektet i begrænset omfang at trække på konsulentbistand til at bearbejde materiale fra Norge, Sverige, Finland og Island. Dette konsulentarbejde har været varetaget af følgende firmaer:

- Finland: Gaia Consulting

- Island: Enrovinice, Stefán Gíslason

- Norge: Menon Business Economics

- Sverige: Teknikmarknad

Menon og Teknikmarknad har efter instruktion fra Karsten Skov lavet en rapport primært om tilskudsmidler i henholdsvis Norge og Sverige. Gaia Consulting har frembragt datamateriale, kommenteret på tekst og oversat finsk materiale, mens Stefán Gíslason, Enrovinice har skrevet hovedparten af afsnittet om Island i udkast, fundet kilderne og kommenteret.

\subsubsection{Workshop}

Resultatet af projektet bliver en rapport på omkring 120-130 sider. Dette vil være en statusrapport med afsnit som peger fremad og forsøges gjort perspektivrig.

Hertil foreslås gennemført en mindre workshop, hvor der deltager et lille antal på måske 3-5 personer pr. land. Workshoppen planlægges i regi af Nordisk Ministerråds sekretariat. Målet med denne workshop kunne være at finde et fælles fokus i dele af indsatserne og dermed sætte ord på mulighederne for samarbejde.

\subsubsection{Bemærkning om tendenser i tiden}

Et eksempel, som er værd at nævne, er, at det danske Institut for Miljøvurdering i marts 2006 satsede på at holde en stor konference om grøn vækst i København. Der var blevet brugt nok op til 10 mio. DKK af et årligt budget på omkring 20 mio. DKK for at markedsføre konferencen om grøn vækst. Der blev udarbejdet en række cases om miljøpolitik og økonomisk vækst, og der blev udgivet en hovedrapport „Grønne veje til vækst“. ${ }^{29}$

${ }^{29}$ Institut for Miljøvurdering: Green Roads to Growth, Proceedings of Expert and Policy Maker Forums, held in Copenhagen 1-2 March 2006, 500 sider. 
Denne rapport må siges at være meget velgennemarbejdet med en række specialanalyser om økonomisk vækst og miljøpolitik. Den er nok temmelig traditionel i sin udprægede klassisk økonomiske tilgang til temaet i forskellige analyser. Anbefalingerne er ikke særlig markante eller klare. Og helt central må man sige, at det store arbejde, dvs. konferencen og hovedrapporten ikke har efterladt sig noget spor i den danske debat eller offentlighed. Arbejdet har vel ikke været spildt. Det har dog kun været akademisk og ikke virkelighedsnært. Eller hvis man skal være positiv, så er initiativet kommet for tidligt til at have nogen blivende effekt.

Internationalt har en række rapporter også tiltrukket sig opmærksomhed. Det er værd at nævne nogle enkelte af disse: Man kan rette blikket mod USA. Ron Pernick og Clint Wilder har skrevet en bog om The Clean Tech Revolution, som også har fået stor opmærksomhed i Europa. ${ }^{30}$ Denne publikation beskriver mulighederne i solenergi, vindenergi, biobenzin, grønne bygninger, smarte netsystemer, mobile technologier og vandfiltration. Herudover beskriver bogen forhold omkring marked, vækst, nye jobs etc. Det er en inspirerende bog, der vælger en række energiteknologier og en enkelt vandteknlogi ud. Den beskriver grøn vækst og miljøeffektive teknologier ud fra en innovations- og investeringstilgang. Det er virksomhedsvinklen, som er afgørende i denne rapport.

Man kan også nævne en anden amerikansk bog: Green to Gold, How smart companies use environmental strategy to innovate, create value, and build competitive advantage. ${ }^{31}$ Denne bog er en gennemgang af, hvad der sker med grønne krav, lovgivning, forbrugerinitiaver, aktieejere etc., så verden ændrer sig, og virksomheder følger miljøargumenter for at tjene penge. Det er også primært en bog for virksomheder til at forstå og initiere grønne ændringer.

Mange andre bøger kan nævnes. Det er dog yderst vigtigt at forstå, hvor international denne bølge er, og hvad man kan læse af forhold og litteratur fra andre lande som inspiration til en perspektivrig indsats.

\footnotetext{
${ }^{30}$ Ron Pernick and Clint Wilder: The Clean Tech Revolution, The next big growth and investment opportunity, New York 2007, 308 sider.

31 Daniel C. Esty and Andrew S. Winston: Green to Gold, How smart companies use environmental strategy to innovate, create value, and build competitive advantage, New Haven and London 2006, 366 sider.
} 



\section{Danmarks indsats for miljøeffektiv teknologi 2004-2011}

\subsection{Dansk erhvervslivs aktiviteter inden for miljøeffektiv teknologi}

Der har været en række kortlægninger af danske virksomheders styrkepositioner inden for miljøeffektiv teknologi. Danske virksomheder indenfor miljøeffektiv teknologi er opgjort af FORA i 2009 til at udgøre ca. 720 virksomheder, som udvikler og sælger miljøeffektive teknologier. ${ }^{32}$ Meget tyder på, at danske virksomheder har gode muligheder på områder som klima og energi, vand og luftforurening. I Danmark er man ret overbevidste om, at der er tale om en sektor, der har fremtiden foran sig. FORA kortlagde også de danske miljøteknologiske virksomheder i 2007 og fik herved et antal på 420. ${ }^{33}$ FORA siger selv, at analysen i 2009 var mere dækkende og omhyggelig. Der var hertil etableret en række nye virksomheder, og en række virksomheder havde skiftet strategi siden 2005 i retning af miljøeffektiv teknologi. Konklusionen på FORAs arbejde er, at den miljøteknologiske klynge ikke på tilfredsstillende vis kan afgrænses alene ud fra registeroplysninger hos Danmarks Statistik, og at der er en række metodiske opgørelsesproblemer i forbindelse med sektoren. På trods af denne konklusion er der dog lavet ganske meget arbejde med forskellige beskrivelser af sektoren.

Den overordnede konklusion på FORAs arbejde er, at der i Danmark er identificeret 720 virksomheder, som udvikler og sælger miljøeffektive teknologier. Disse virksomheder har godt 120.000 ansatte og omsætter for mere end 300 milliarder. De eksporterer samlet for $120 \mathrm{mia}$. DKK om året. Industrivirksomheder eksporterer procentvis (60 \%) mere af produktionen end gennemsnittet og dermed også virksomheder med forretningsservice bredt forstået. FORA nævner selv, at der er tale om et vist overlap af virksomhederne i de forskellige kategorier, i og med at virksomheder har opgaver indenfor flere kategorier og følgelig registre-

\footnotetext{
32 FORA (Økonomi- og Erhvervsministeriets enhed for erhvervsøkonomisk forskning og analyse): Kortlægning af Miljøteknologiske virksomheder i Danmark, udarbejdet for Miljøstyrelsen, marts 2009, 65 sider. 33 FORA: Miljøteknologiske styrkepositioner - en erhvervsanalyse af klyngedannelse, udarbejdet for Miljøstyrelsen, juni 2006,
} 
rer sig i flere kategorier. Virksomhederne har også andre opgaver, som ikke har med miljø at gøre, hvorfor en del af de ansatte heller ikke kan siges at arbejde med miljø. Herved forekommer der samlet set en vis overvurdering af virksomhedernes forhold etc.

I en anden analyse af Brøndum \& Fliess er de danske cleantechvirksomheder opgjort til $490 .^{34}$ Denne rapport er et samarbejde mellem Energistyrelsen, DI (Dansk Industri) og Brøndum \& Fliess. Der arbejdes med 4 teknologiområder for miljø: bæredygtige materialer, affald og genbrug, vand og spildevand, samt luft og miljø, og 4 teknologiområder for energi: grøn energiproduktion, effektivisering af energiforbrug, energiinfrastruktur og energilagring. Analysen baserer sig på en kombination af registerdata og internetbaseret spørgeskemaundersøgelse. Rapporten er præget af resultater fra spørgeskemaundersøgelsen og giver gode informationer om virksomheders konkrete forhold.

I august 2011 udgives en ny rapport af Brøndum \& Fliess om dansk cleantech eksemplificeret ved 7 studier af enkeltvirksomheder. ${ }^{35}$ Man har udvalgt 7 cleantech virksomheder, som typisk har et mindre antal ansatte, omkring 30. De er kendetegnet ved at have en ung profil, lovende vækstrater og ambitiøse mål. De er gode til forskning og udvikling gennem egne ressourcer, mens de er langt svagere til markedsføring og strategisk ledelse. På en måde kan denne analyse siges at bringe de danske analyser af virksomhederne, der arbejder med miljøeffektiv teknologi, videre frem mod at beskrive, hvad der yderligere skal til for, at de kan få succes. Et svar herpå er, at virksomhederne i højere grad skal sætte kunder og netværk i centrum fremover. Analysen giver både et mikroperspektiv på, hvad virksomhederne selv skal gøre fremover, og et makroperspektiv på, hvad man overordnet skal gøre, ikke mindst fra statens side. Staten skal både tænke på at forbedre tilskudsgivningen og på at skabe et hjemmemarked for virksomhedernes produkter. Som en interessant detalje nævner rapporten, at der er 1.200 cleantech virksomheder i Danmark. Dette underbygges på intet tidspunkt og må følgelig betragtes som en påstand. Brøndum \& Fliess havde året forinden analyseret sig frem til, at der var 490 virksomheder i Danmark.

I disse opgørelser og beskrivelser af sektoren for miljøeffektiv teknologi i Danmark har man fokuseret på, hvor mange virksomheder, der eksisterer, hvor store de er, hvor meget de producerer og hvor mange ansatte de har, samt hvor meget de eksporterer. Det viser sig, at de eksisterende registreringer og brancheinddelinger ikke kan anvendes direkte eller alene. Der skal sammenstykkede analyser til, og der forekommer en vis usik-

\footnotetext{
34 Brøndum \& Fliess: Cleantech - i vækstens tegn. Guldægget i dansk økonomi 2010, oktober 2010, 69 sider. Samme firma udgav også en analyse i 2009.

35 Brøndum \& Fliess: Cleantech - with the customer in focus - The Golden Egg of Danish economy 2011 with inspiration from seven cases, juni 2011, 57 sider.
} 
kerhed i forbindelse med opgørelserne. Dog vurderes det at være en fordel, hvis der årligt gennemføres opgørelser efter samme principper.

Som eksempel på en analyse, som begrænser sig til kun at tage dele af miljøeffektiv teknologi med kan man nævne Baggrundsrapport om danske styrkepositioner på klimaområdet fra august $2008 .{ }^{36}$ Både virksomheder, der leverer løsninger til at reducere klimagasser, og virksomheder, der leverer løsninger til klimatilpasning er omfattet. Datamaterialet er fra 2001-2005, men på tidspunktet det nyeste talmateriale. Dette er en udmærket oversigtsanalyse med en række interessante detaljer.

Som et andet eksempel kan man nævne vandsektoren, som FORA i 2009 opgør til 205 virksomheder. De beskæftiger 35.000 ansatte og har en eksport andel på 35 \% Det er også værd at nævne særskilte analyser af vandsektoren, som kun gennemgår vand og dermed kan nå dybere $\mathrm{i}$ analysen. Man kan nævne Erhvervs- og Boligstyrelsens rapport: Kompetenceklyngen Vand - en analyse af virksomheder og deres rammebetingelser og en kort artikel af Karsten Skov: Visioner for vandteknologi, december 2009. Det er noget nemmere at forstå en del af virksomhederne, når de afgrænses til samme område, f.eks. vand. ${ }^{37}$

Man kan håbe på, at der på sigt kommer mere valide informationer om sektoren eller de enkelte dele heraf. Det vigtigste er dog, at aktørerne, dvs. det offentlige og sektoren eller dele heraf, har mere nøjagtige informationer om, hvem virksomhederne er, og hvad de reelt har brug for til at forbedre sig.

\subsubsection{Dansk eksport af miljøeffektiv teknologi}

Eksporten fremstår som noget af det mere interessante i opgørelsessammenhæng, idet det siger noget om, hvad virksomhederne kan internationalt, og hvad de bibringer et lands økonomi, ikke mindst i små åbne økonomier, som de nordiske.

Energistyrelsen har sammen med DI Energibranchen fastlagt energiområdets eksportandel og udgiver hvert år en opgørelse over, hvor stor eksporten er. Det seneste år er Erhvervs- og Byggestyrelsen også deltager i analysen. Formålet med opgørelsen af dansk eksport af energiteknologi og -udstyr er at dokumentere betydningen af den danske energiindustri for samfundsøkonomien, beskæftigelsen og udbredelsen af det globale marked. Denne opgørelse må nok anses for at være det mest holdbare datagrundlag for området. ${ }^{38}$

\footnotetext{
36 Erhvervsklimapanelet: Baggrundsrapport om danske styrkepositioner på klimaområdet, august 2008, 97 sider. 37 Erhvervs- og Boligstyrelsen: Kompetenceklyngen Vand - en analyse af virksomheder og deres rammebetingelser, oktober 2002, 30 sider, og Karsten Skov: Visioner for vandteknologi, december 2009, 6 sider. 38 Dræbye: Grundlaget for statistik for energierhvervene, april 2010.
} 
I maj 2011 er Energierhvervsanalyse 2010 blevet offentliggjort. Den viser, at Danmark i 2010 eksporterede energiteknologi og -udstyr for 52,2 mia. DKK. ${ }^{39}$ Dette er et fald på 10,8 \% i forhold til 2009, hvor eksporten var 58,5 mia. DKK. Energiteknologieksportens andel af den samlede danske eksport af varer faldt fra 11,7 \% i 2009 til 9,5 \% i 2010. Forklaringen kan være, at danske virksomheder mister markedsandele eller det kan være et resultat af udflytning af dansk produktion. Finanskrisen spiller givetvis også ind.

Nogle samlede nøgletal er opgjort i forbindelse med et notat til regeringens Vækstforum om en analyse af dansk cleantech. ${ }^{40}$ Dansk eksport af miljøeffektiv teknologi blev opgjort 93 mia. DKK i 2008 svarende til 16 $\%$ af den samlede vareeksport. Eksporten af energiteknologi blev samme år opgjort til 66 mia. DKK svarende til $11 \%$ af den samlede vareeksport, mens eksporten af miljøteknologi i 2008 var på 43 mia. DKK svarende til $7 \%$ af den samlede vareeksport. Der er et talmæssigt overlap på 16 mia. DKK, hvilket er et betydelig tal i en sådan sammenhæng, og dette sætter usikkerheden i perspektiv. Især er der ikke redegjort særlig godt for eksporten af miljøteknologi. Samtidig viser tallene også, at det er gået tilbage i de sidste 2 år, når man sammenholder 08, 09 og 10 tallene. Finanskrisen må ikke glemmes som en påvirkende faktor.

Vindindustriens organisation opgør egne tal for vindmølleindustrien. Her blev eksporten opgjort til en stigning på $11 \%$ til 46,2 mia. DKK i 2010 mod 41,7 mia. DKK i 2009. 2010 var dermed mod forventning et virkeligt godt år for Vestas, Siemens Wind Power, LM Glasfiber og de mange underleverandører i Danmark. Sammenholdes disse tal med de overordnede tal for eksporten af energiteknologi i 2010 er der kun 6 mia. DKK tilbage til eksport af andet end vindmølleindustri. Dette kan simpelthen ikke stemme. Forklaringselementer kan være, at vindmølleindustrien, som kun anvender spørgeskemaer til egen branche, får mere med. De har rådgivning med og flere komponenter, der ikke umiddelbart i den officielle statistik indgår som relateret til miljøeffektiv teknologi. Samlet må man dog konkludere, at vind er den helt overvejende del af energiteknologien, og at denne del af branchen ikke har oplevet 2010, som et nedgangsår, snarere tværtimod. Omvendt kan vindmølleindustriens tal være overvurderede, fordi de bygger på spørgeskemaunders $\emptyset$ gelse og næppe kan være fuldstændige.

Det kan konkluderes, at energiområdet nok har fundet sin form, hvad angår eksporttal. Det kunne dog også være relevant at have bedre tal for de enkelte områder af energiområdet, især hvis man kan løse forskellen

\footnotetext{
${ }^{39}$ Energistyrelsen, DI Energibranchen og Erhvervs- og Byggestyrelsen: Energierhvervsanalyse 2010, maj 2011, 16 sider.

${ }^{40}$ Regeringen: Grøn Vækst, Analyse af Dansk CleanTech, februar 2010, 14 sider.

41 Vindmølleindustrien: pressemeddelelse og notat af den 11. marts 2011.
} 
mellem energi generelt og vind i 2010, som nævnt. Tal på miljøområdet er ikke tilstrækkelig godt forklarede. Miljøområdet bør derfor have bedre og mere konsistente opgørelser for eksport, gerne opdelt på enkelte områder, fordi områderne er så forskellige.

\subsection{Vurderinger og initiativer for miljøeffektiv teknologi i Danmark}

\section{Centrale aktører i Danmark på myndighedsplan}

I Danmark er der flere ministerier, der er ansvarlige for dele af aktiviteterne i forbindelse med miljøeffektiv teknologi. Miljøministeriet, Klima- og Energiministeriet, Økonomi- og Erhvervsministeriet, Forskningsministeriet, Fødevareministeriet, Transportministeriet og Udenrigsministeriet er de centrale aktører.

Miljøstyrelsen, en styrelse under Miljøministeriet, forvalter tilskudsaktiviteter på ministeriets område og er reguleringsansvarlig på miljøområdet sammen med Naturstyrelsen.

Energistyrelsen, en styrelse under Klima- og Energiministeriet, forvalter tilskudsaktiviteter på ministeriets område og er reguleringsansvarlig på energiområdet.

Forsknings- og Innovationsstyrelsen, en styrelse under Forskningsministeriet, eller Ministeriet for Videnskab, Teknologi og Udvikling som det formelt hedder, forvalter forskningsmidlerne i Danmark.

Erhvervs- og Byggestyrelsen, en styrelse under Økonomi- og Erhvervsministeriet, forvalter de erhvervsrelaterede tilskudsmidler, bl.a. Fornyelsesfonden.

FødevareErhverv, en styrelse under Fødevareministeriet, forvalter de landbrugsrelaterede tilskudsmidler, primært GUDP.

Transportministeriet som har oprettet et Center for Grøn Transport.

Eksportrådet, en afdeling under Udenrigsministeriet, er ansvarlig for eksportaktiviteter.

Med regeringsskiftet i oktober 2011 er der sket en række mindre navnemæssige ændringer i ministerierne. Dette er ikke medtaget i denne publikation, idet afsnittet er formuleret inden dette tidspunkt. Det har dog kun minimal betydning for forståelsen.

\section{Tilbageblik på tidligere aktiviteter}

I Danmark har der været flere aktiviteter fra statslig side til fremme af miljøeffektiv teknologi før 2004, som er året for den nye indsats fra EUkommissionen. Der har været flere programmer på Miljøministeriets område, f.eks. for renere teknologi og senere for renere produkter. Med regeringsskiftet i 2001 blev der skåret en del i Miljøministeriets tilskudsmidler og f.eks. blev ordningen for renere produkter afviklet. Dog fik man en såkaldt „virksomhedsordning“, som gav mulighed for at støtte miljøeffektiv teknologi i forhold til virksomheder i snævert samarbejde med Dansk Indu- 
stri (DI). Der var dog betydelig færre midler til tilskud end tidligere. Få og små perspektivrige projekter blev støttet med denne ordning.

Energiområdet har også før 2004 haft betydelige midler efter dansk målestok til energiforskning og også enkelte midler til demonstration, givet den store fokus på klima og energi, ikke mindst vedvarende energi. Især har der været fokuseret på udbygning af forskellige former for vedvarende energi som vind og biomasse.

Med EU-kommissionens arbejde for ETAP blev der vagt en politisk interesse for at fremme miljøeffektiv teknologi og et arbejde til fremme heraf blev iværksat, som det vises nedenfor.

\section{Redegørelsen om fremme af miljøeffektiv teknologi}

I maj 2006 udgav regeringen en Redegørelse om fremme af miljøeffektiv teknologi - vejen til et bedre miljø. ${ }^{42}$ Miljøminister Connie Hedegaard havde taget initiativ til, at Miljøministeriet skulle lave en redegørelse på regeringens vegne med inddragelse af andre ministerier. Redegørelsen havde 9 konkrete initiativer:

1. Partnerskab for innovation

2. Målrettet og styrket eksportfremme

3. Forskning og teknologiudvikling i miljøets interesse

4. Styrket indsats for fremme af miljøeffektiv teknologi i Miljøministeriet

5. Målrettet fremme af miljøeffektiv teknologi i EU

6. Klima og energiteknologi

7. Miljøbelastning fra husdyrbrug

8. Et rent og uspoleret vandmiljø

9. Et sundt miljø

Redegørelsen var tænkt som et offentligt debatoplæg, og det blev fremhævet, at regeringen i efteråret 2006 ville fremlægge en mere detaljeret og konkret handlingsplan for miljøeffektiv teknologi.

Politisk aftale mellem regeringen om Dansk Folkeparti om fremme af miljøeffektiv teknologi 2007-2009 (4. november 2006) ${ }^{43}$

I november 2006 indgik regeringen, dvs. Venstre (V) og Konservative (K) og Dansk Folkeparti en aftale baseret på Folketingets vedtagelse af V 20 fra maj 2005 og den ovennævnte redegørelse. I aftalen står, at „øget udvikling og anvendelse af miljøeffektiv teknologi i kombination med effektive ramme betingelse, herunder målrettet regulering, kan give et væsentligt

42 Regeringen: Redegørelse om fremme af miljøeffektiv teknologi - vejen til et bedre miljø, maj 2006, 19 sider. ${ }^{43}$ Aftale mellem regeringen og Dansk Folkeparti om fremme af miljøeffektiv teknologi 2007-2009 (4. november 2006). 
bidrag til løsningen af en række nationale og globale miljøproblemer og samtidig bidrage til vækst og beskæftigelse."

Under denne overskrift blev der sat midler af for perioden 2007-2009 på Finansloven for 2007:

- Samspil med virksomheder 7 mio. DKK

- Rådgivning, information og eksportfremme 19 mio. DKK

- Indsats på vandområdet 23 mio. DKK

- Indsats for sundhed og miljø 26 mio. DKK

- Landbrugsindsats 45 mio. DKK

- I alt 120 mio. DKK

\subsubsection{Danske handlingsplaner for fremme af miljøeffektiv teknologi i Miljøministeriets regi}

I maj 2007 udsendte miljøministeren en høringsudgave af regeringens handlingsplan og i juli blev den endelige version af handlingsplanen udsendt som Regeringens handlingsplan for fremme af miljøeffektiv teknologi. ${ }^{44}$

Handlingsplanen havde som redegørelsen de samme 9 punkter. Dog var punkt $4 \mathrm{nu}$ formuleret som: rådgivning, information og vidensopbygning mod tidligere: indsats i Miljøministeriet. Og punkt 7 fik en mere specifik titel: miljøeffektive landbrugsteknologier. Nedenfor gennemgås indsatsen for de 9 punkter.

Det interessante ved Danmarks handlingsplan for miljøeffektiv teknologi er, at den omfatter flere centrale ministeriers indsats og ikke kun Miljøministeriets indsats. På tidspunktet for udgivelsen var klimaansvaret placeret i Miljøministeriet. Energi, forskning og landbrug var placeret i andre ministerier. Der er i planen en kort beskrivelse af ressortfordelingen mellem ministerierne på de enkelte områder.

I planen beskrives finansiering også detaljeret. Ud over de allerede nævnte 120 mio. DKK, jf. ovenfor, nævnes:

- En særlig indsats mod partikelforurening på 63,5 mio. DKK i

Miljøministeriet

- En aftale mellem Fødevareministeriet, Miljøministeriet, og landbrugserhvervet om at bruge 255 mio. DKK på fremme af miljøeffektive landbrugsteknologier. Denne indsats er koblet til EU's landdistriktsmidler. De 45 mio. DKK kommer fra de 120 mio. DKK nævnt ovenfor

${ }^{44}$ Regeringen: Danske løsninger på globale miljøudfordringer. Regeringens handlingsplan for fremme af miljøeffektiv teknologi, maj 2007, 63 sider. 
- 144 mio. DKK til et nyt strategisk forskningsprogram for miljøteknologi under Videnskabsministeriet. Det kan i denne forbindelse nævnes, at Det Strategiske Forskningsråd havde 249 mio. DKK til „miljø og energi“, „vand“, og „vedvarende energi sat i system“ i årene 2007-08, som allerede afsatte midler

- Midlerne tildelt til energiprogrammer, jf. afsnittet om klima- og energiområdet nedenfor

\section{Reguleringsgrundlag}

Hjemmelsgrundlaget for at anvende midler er Finansloven, hvor midlerne er skrevet ind i relation til den politiske aftale. Desuden er der senere udarbejdet en bekendtgørelse om tilskud til miljøeffektiv teknologi, som giver en række detaljer for tilskuddene. ${ }^{45}$

\section{Organisation}

I Miljøministeriet er der placeret et sekretariat i Miljøstyrelsen, som varetager koordineringen af opgaverne i forbindelse med handlingsplanen. Der er afsat 7 årsværk årligt i Miljøstyrelsen i de år handlingsplanen kører.

Miljøministeriet har ikke koordineret aktiviteterne i forbindelse med handlingsplanen, om end der i planen er lagt op til dette. Dette skyldes nok, at de øvrige ministerier ikke efterspørger en sådan koordinering og nok føler den som „styrende“. Imidlertid er der etableret en koordinering i regi af Økonomi- og Erhvervsministeriet, som har karakter af formel informationsudveksling.

\subsubsection{Handlingsplan for fremme af miljøeffektiv teknologi 2010-2011}

I februar 2010 udgav regeringen en opfølgning af handlingsplanen: Miljøteknologi - til gavn for miljø og vækst. Denne forlængelse af handlingsplanen blev økonomisk forhandlet til enighed med samtlige partier i Folketinget i oktober 2009. ${ }^{47}$ Det er egentlig usædvanligt, at samtlige partier i det danske Folketing er med i en sådan aftale, ikke mindst set i forhold til den første politiske aftale, som kun omfattede regeringen og Dansk Folkeparti.

Aftalen indebærer, at der i årene 2010-2011 afsættes 90 mio. DKK til test, udvikling og demonstration af miljøteknologi inden for områderne vand, affald og luft. Dette er Miljøministeriets eget område, og dermed er fortsættelsen af handlingsplanen snæver, dvs. kun på Miljøministeriets

\footnotetext{
45 Bekendtgørelse nr. 864 af den 30. juni 2010 om tilskud til miljøeffektiv teknologi.

46 Regeringen: Miljøteknologi - til gavn for miljø og vækst. Handlingsplan for fremme af miljøeffektiv teknologi 2010-2011, februar 2010, 37 sider.

47 Pressemeddelelse fra miljøminister Troels Lund Poulsen den 30. oktober 2009, og Aftale om en ny handlingsplan til fremme af miljøteknologi, den 29. oktober 2009.
} 
område. Der har følgelig heller ikke været et langvarigt forhandlingsforløb med de øvrige ministerier om forlængelse af handlingsplanen .

Forlængelsen af handlingsplanen, man kan kalde den Handlingsplan 2, har en række indsatsområder som benævnes under følgende overskrifter:

- Vand

- Affald

- Luft

- Internationalt

- Regulering

- Partnerskaber

- Offentlig efterspørgsel

Fordelingen af midlerne er 82,5 mio. DKK til udvikling af forskellige teknologier, dvs. nr. 1,2 og 3. Heraf afsættes 10 mio. DKK til aktiviteter i udlandet. De resterende midler 7,5 mio. DKK afsættes til temaerne 4, 5 og 6. Det bemærkes, at 5 mio. DKK er reserveret til opfølgning i 2012.

Generelt må man sige om Handlingsplan 2, at den i sig bærer erfaringerne fra den første handlingsplan, som spændte meget bredt. Nu synes aktiviteterne at være mere målrettede og noget nemmere at forfølge. Alligevel er temaerne stort set ens. Affald er dog kommet med som indsatsområde, ligesom offentlig efterspørgsel også må betegnes som et nyt indsatsområde. Nyt er det også, at der kan gives tilskud til danske virksomheder, der ønsker at gennemføre udviklings- og demonstrationsprojekter i Kina eller Indien.

I maj 2011 indgås en ny politisk aftale om Danmark som vækstnation mellem regeringen og Dansk Folkeparti, og heri afsættes der 130 mio. DKK til en ny miljøteknologisk indsats for årene 2012-2015. Denne er tænkt som fortsættelse af den hidtidige indsats i Miljøministeriets regi. ${ }^{48}$ Hermed er den fortsatte aktivitet sikret på nogenlunde det niveau, som den har været i 2011. Der er dog en vis irritation fra erhvervslivet over, hvad man mener, er for få midler. ${ }^{49}$

Det nye regeringsgrundlag fra oktober 2011: Et Danmark, der står sammen har ganske meget med om klima, energi og miljø under afsnittet grøn omstilling. ${ }^{50}$ Der står en mængde flotte ord om grøn økonomi og erhvervsudvikling som f.eks. vigtigheden af hjemmemarkedet og tilrettelæggelsen af de rigtige incitamenter som intelligent grøn regulering. I grundlaget nævnes effektive ren-luftzoner i byerne, fremme af bæredygtig byudvikling, substitution af farlige stoffer i produkter, en ny strategi for bæredygtig udvikling

\footnotetext{
48 Pressemeddelelse fra Miljøministeriet den 27. maj 2011, samt Aftale om Danmark som vækstnation 15 sider. ${ }^{49}$ Berlingske den 17. juni: DI: Regeringen svigter dansk miljøteknologi.

50 Regeringen: Et Danmark, der står sammen, Regeringsgrundlag, oktober 2011, 76 sider.
} 
som eksempler på, hvad man vil gøre på miljøområdet. Man nævner ikke tilskud til miljøeffektiv teknologi eller miljøteknologi.

Primo november annoncerer den nye miljøminister, at der tilføres 50 mio. DKK ekstra til den danske indsats i Miljøministeriets regi i 2012. ${ }^{51}$ Der skal nu også oprettes et rigtigt Miljøteknologisk Udviklings- og Demonstrationsprogram (MUDP), og der vil være i alt 77 mio. DKK til rådighed i 2012.

\subsubsection{Handlingsplanernes initiativer}

Nedenfor gennemgås 9 aktiviteter under den første handlingsplan, samt også aktiviteter under den anden handlingsplan. De 9 aktiviteter nævnes A-I, mens en ny aktivitet er J, affald under den anden handlingsplan.

\section{A) Partnerskab for innovation ${ }^{52}$}

At fremme partnerskaber mellem virksomheder, vidensmiljøer og myndigheder er højt prioriteret, idet det forudsættes, at der opstår en særlig synergi mellem de fælles interesser, som eksisterer om et fælles tema. Der har klart været et stort behov for at sætte skub i forskellige former for partnerskabet for at fremme konkrete samarbejder. Der findes muligheder for partnerskaber for at modtage tilskud ikke kun fra handlingsplanen, men også fra Videnskabsministeriet og Økonomi- og Erhvervsministeriet.

Som udgangspunkt var det planen, at etablere 5 partnerskaber, men allerede i 2008 var der etableret 7 partnerskaber. I alt kan der opregnes partnerskaber indenfor følgende områder:

- Vand (etableret 2006 - afrundet 2011)

- Miljøeffektive landbrugsteknologier, primært gylle (etableret 2007)

- Megavindmøller (etableret 2007)

- Biobrændstoffer (etableret 2007)

- Brint og brændselsceller (etableret 2007)

- Lavenergibyggeri

- Ballastvand (etableret januar 2010)

- Renere skibsfart (etableret i november 2010)

- Offentlig efterspørgsel og fremme af ny dansk teknologi (etableret december 2010)

- Spildevand i Indien (etableret 2010)

- Grundvand i Shandong provinsen i Kina (etableret i november 2010)

\footnotetext{
51 Miljøministeriet: pressemeddelelse af den 1. november 2011.

52 Referencer til af snittet om partnerskaber er primært: Miljøstyrelsens internetside om ecoinnovation.dk, hvor hvert partnerskab gennemgås. Og Miljøstyrelsen: Redegørelse for regeringens indsats for miljøteknologi, oktober 2009.
} 
- Spildevand i Chongging (etableret i maj 2011)

- Shredderaffald (juni 2011)

- Lokal håndtering af regnvand (april 2011)

- Partnerskab for genvinding af fosfor (etableres i løbet af 2011)

Den deltagende myndighed er typisk enten Miljøstyrelsen, Energistyrelsen eller Naturstyrelsen alt efter ressortfordeling.

Ved samarbejdet i partnerskaberne fremkommer der f.eks. analyser af forureningsforhold, erfaringer, miljøkonsekvenser, nye teknologiske forhold, markeder og behov etc. bl.a. forsøger man nogle gange at kortlægge den regulering, som sætter rammerne for efterspørgslen. Det kan også være samarbejde om strategier eller om formulering af projekter.

Som et eksempel på en teknologiudvikling, der er fremkommet i partnerskabssammenhæng, kan nævnes reduktion af klorforbruget i svømmehaller med op til 80 \% Et lille firma Skjølstrup og Grønborg har sammen med andre eksperter og virksomheder udviklet en vandrensningsteknologi, så behovet for brug af klor reduceres. Teknologien er taget i brug på Bernstorffsminde Efterskole og feriestedet Lalandia i Rødby.

Partnerskaberne i udlandet skal ses i sammenhæng med ønsket om eksportfremme og test og demonstration af teknologi. Herved kan der vises demonstrationsanlæg i enkelte lande, som kan have en meget vigtig spredningseffekt.

Partnerskabet for Renere skibsfart kom i kølvandet på en række skærpede krav til den internationale skibsfart, som FNs søfartsorganisation IMO vedtog i oktober 2008. Danmarks Rederiforening, Miljøstyrelsen og Søfartsstyrelsen deltager i partnerskabet. Det må betegnes som meget succesrigt og har udarbejdet en handlingsplan for 2010-2011. ${ }^{53}$ Forskellige projekter er i igangsat: 1) NOx reduktion på ældre skibsmotorer med LowNOx ventil ${ }^{54}$ 2) reduktion af SOx og partikler ved brug af scrubbere, 3) NOx reduktion med SCR katalysatorer, 4) udvikling af partikelfiltre til skibsmotorer, (disse 4 projekter er støttet af Miljøstyrelsens tilskudsordning, 5) naturgasdrift af skib (støttet af energiselskabet DONG Energy).

Partnerskabet for Ballastvand har til formål at arbejde med de opgaver, som Ballastvandkonventionen kræver for at begrænse udbredelsen af invasive arter, som kan sprede sygdomme, påvirke økosystemer etc. Fra 2016 skal alle skibe behandle ballastvandet. Partnerskabet er et samarbejde mellem Danmarks Rederiforening, Søfartsstyrelsen og Naturstyrelsen.

\footnotetext{
53 Partnerskab for Renere Skibsfart. Handlingsplan 2010-2011, 12 sider.

54 Miljøstyrelsen: Udvikling og godkendelse af low NOx indsprøjtningsdyse til 2-takts dieselmotorer, Miljøprojekt 1361, 2011, udført af MAN Diesel og Turbo, 23 sider.
} 
De 4 partnerskaber inden for energiområdet er tilknyttet Klima- og Energiministeriets aktiviteter. Der udarbejdes fælles udviklingsplaner og forretningsstrategier, f.eks. udgav brint/brændstoffer i starten af 2008 en strategi for teknologi- og markedsudvikling, og megavindmøller har udgivet en række rapporter om perspektiverne for vindenergi. De energirettede partnerskaber modtager støtte fra EUDP, jf. nedenfor. Partnerskabet for biobrændstoffer er lukket i starten af 2010, nok fordi der ikke er så mange deltagere, og der ikke er så stort et behov for at drøfte fælles problemstillinger.

Partnerskabet for offentlig efterspørgsel og fremme af ny dansk miljøteknologi er relativt nyt fra december 2010. Formålet er at kortlægge, hvor der kan samarbejdes om den offentlige efterspørgsel som drivkraft for teknologiudvikling. Der er i foråret 2011 afsat 5 mio. DKK til fremme demonstrationsprojekter, hvor virksomheder kan demonstrere projekter i kommunerne.

\section{B) Målrettet og styrket eksportfremme}

Dette mål i handlingsplanen er at styrke danske virksomheders eksport af miljøeffektiv teknologi. Indsatsen gennemføres af Danmarks Eksportråd (en afdeling under Udenrigsministeriet), Klima- og Energiministeriet og Miljøministeriet. Der har i handlingsplanen været afsat 6 mio. DKK til denne indsats.

Indsatsen har hovedsagelig rettet sig mod BRIK-landene (Brasilien, Rusland, Indien og Kina), som udgør interessante markeder for miljøeffektiv teknologi, eftersom de har stor vækst og også forsøger at takle miljøproblemer. Der har været aktiviteter i alle 4 lande, men indsatsen er koncentreret om Kina og Indien - og i disse to lande er der fokus på få udvalgte regioner. Samtidig med at der er gennemført eksportfremstød i disse lande, har der været eksportfremmende aktiviteter i flere andre lande, bl.a. Tyskland, Spanien, Australien, Tyrkiet etc., og der har været en række udenlandske besøg i Danmark for at besigtige demonstrationsanlæg og høre om dansk miljøindsats.

Der er blevet udarbejdet et fyldigt materiale til enkelte områder, bl.a. vand, for at kommunikere danske kompetencer. „Danish Lessons“ kan ses på www.ecoinnovation.dk som en række temaer, hvor der fortælles om, hvordan Danmark har reguleret et vandområde, og hvilke teknologier eller løsningsmodeller, der er blevet anvendt til at løse opgaven.

Der er stor interesse blandt danske virksomheder for disse eksportfremstød og de medfølgende aktiviteter, fordi man har myndighederne med på begge sider. Især mindre virksomheder kan opnå gode resultater ved at komme ind på markeder, hvor de ikke hidtil har haft aktiviteter. Erfaringen er også, at det er muligt at vise koblingen mellem stram miljøregulering og udviklingen og demonstrationen af en række perspektivrige miljøeffektive teknologier. 


\section{C) Forskning}

Forskningsaktiviteterne varetages af Videnskabsministeriet, hvor man kan nævne flere fonde eller råd, som støtter forskning i miljøeffektiv teknologi: Rådet for Teknologi og Innovation, Højteknologifonden og ikke mindst Det Strategiske Forskningsråd (DSF). DSF gennemfører en række projekter under temaet „energi og miljø“. Som medfinansiering af strategisk forskning i konkurrencedygtige miljøteknologier med fokus på bl.a. vand, kemi, jordforurening, og landbrug har der i årene 20072010 været afsat 190 mio. DKK.

Danmark har i en årrække opprioriteret forskningsindsatsen, først mere fri forskning og herefter, dvs. fra 2005-2006 også strategisk forskning, hvor staten har støttet områder, som man ønskede særlig fokus på, f.eks. energi og miljø. Forskningsbevillingerne er bygget op om en række råd eller fonde om man vil, som skal bevilge midlerne til de forskellige temaer. Midlerne til konkurrencedygtige miljøteknologier gives typisk til universiteter, som samarbejder med private virksomheder. Højteknologifonden kan dog give direkte støtte til virksomheder. Om denne fokus på universiteter kan man sige, at den skulle løfte en række forskningsmiljøer i begyndelsen, men efterhånden synes der at være en betydelig effekt i form af meget aktive universitetsmiljøer.

Eftersom de 190 mio. DKK ikke er beskrevet samlet, men kun som enkeltprojekter på Videnskabsministeriets eller Forskningsstyrelsens hjemmeside, er de ikke beskrevet detaljeret her, og der henvises til denne hjemmeside.

Det er ikke muligt at vurdere, hvilken kobling der er mellem disse strategiske forskningsprojekter og de mere udviklingsprægede projekter fra Miljøministeriet. Der synes ikke at være en tæt koordination mellem de aktiviteter, der gennemføres af Videnskabsministeriet og de aktiviteter, der gennemføres af Miljøministeriet, om end der naturligvis eksisterer viden om, hvad den anden part foretager sig i tilskudsaktiviteter.

\section{D) Rådgivning, information og vidensopbygning}

Under denne overskrift er der afsat 13 mio. DKK. Disse midler går til at hjælpe virksomheder med miljøfaglig bistand til projekter, rådgivning om finansieringsmuligheder, udarbejdelse af informationsmateriale, bl.a. et katalog over vidensinstitutioner på miljøområdet, analyser af danske virksomheders styrkepositioner, beskrivelse af cases, opgørelse af dansk eksport på cleantech, etc.

Disse aktiviteter gennemføres primært af det sekretariat, som Miljøministeriet har oprettet i Miljøstyrelsen til varetagelse af handlingsplanen, jf. overfor. Hjemmesiden www.ecoinnovation.dk er en samlet indgang for virksomheder, iværksættere og andre, der søger information og følger udviklingen på miljøteknologiområdet. 


\section{E) Målrettet fremme af miljøeffektiv teknologi i EU}

Målet er at deltage i EU's aktiviteter til fremme af miljøeffektiv teknologi. Danmark deltager aktivt i opfølgningen og udviklingen af EU's handlingsplan for miljøeffektiv teknologi - ETAP. Hertil følges løbende med i de forskellige støtteordninger, som EU har med relevans for miljøeffektiv teknologi.

Det kan nævnes, at især den nye forordning om en europæisk verifikationsordning for miljøteknologi, har haft Miljøministeriets interesse og fokus for mulighed for påvirkning. I forlængelse heraf har 3 danske GTS institutter (Godkendte Teknologiske Serviceinstitutter) oprettet et dansk center for verifikation af miljøteknologier (DANETV), som også har modtaget støtte fra Videnskabsministeriet.

I Handlingsplan 2 fokuseres især på, hvordan man kan påvirke prioriteringen af EU's indsats for fremme af miljøeffektiv teknologi - som en del af et kommende 7. miljøhandlingsprogram for EU. Dette nye miljøhandlingsprogram forventes færdigt under dansk formandskab af EU i 2012.

\section{F) Resultater fra Miljøministeriets indsats}

Under Miljøministeriets handlingsplan er der i 2007 til og med 2010 støttet 88 udviklings- og demonstrationsprojekter. Produktionsvirksomheder indgår i 63 \% af projekterne, mens private virksomheder (inkl. konsulentvirksomheder) indgår i $80 \%$ af projekterne. ${ }^{55}$

Nedenfor i afsnittene om vand, luft, affald og andet gennemgås omfanget af støtten under handlingsplanerne fra 2007 til og med 2010. Gennemgangen bygger på de lister, som Miljøstyrelsen laver over støttede projekter for hvert år, og som er på Miljøstyrelsens hjemmeside www.ecoinnovation.dk. ${ }^{56}$ Listerne har et ganske lille resume og nogle få informationer som: tilskud, tilskudsprocent, projektperiode, brancheoplysning og firmakontakt. Man kunne udmærket ønske sig noget mere information om projekterne, f.eks. i form af mere beskrivelse af de enkelte projekter.

\section{G) Et rent og uspoleret vandmiljø}

Vand er med afstand det område under handlingsplanerne, som har modtaget mest støtte. I årene 2007 til og med 2010 blev 43 projektet til i alt 34,122 mio. DKK støttet. Vand står for halvdelen af projekterne. I gennemsnit modtog disse projekter lidt under 0,8 mio. DKK i tilskud. Der er mange mindre eller meget små projekter, mens der ikke er mange, som er store. Det største tilskud er lige under 2 mio. DKK til et enkelt projekt. Projekterne støttes ofte med $50 \%$ eller deromkring.

\footnotetext{
55 Miljøstyrelsen: Kort rids af Miljøministeriets miljøteknologiske indsats, 4. marts 2011, 3 sider

56 Projektlister over årene: 2008, 2009 og 2010.
} 
En række af projekterne relaterer sig til at håndtere klimaændringernes påvirkning af vandforhold. Der udvikles teknologi og løsninger til at håndtere fremtidens større regnmængder. Målet med flere af projekterne er at bruge vandet konstruktivt i stedet for at lede det direkte bort igennem kloaknettet. Andre eksempler på projekter er ny udformning af faskiner til at omsætte regnvand hurtigere til grundvand, dobbeltporøs filtrering af vand fra veje, mikrorenseanlæg til at rense regnvand til genbrug, flere projekter med genbrug af vand. Der er også projekter, som skal vurdere eller teste nye teknologiske metoder som f.eks. on-line målinger mv.

Derudover satses der på forbedret spildevandsrensning, f.eks. optimeret rensning eller alternativ rensning, samt rensning af hospitalsspildevand. Netop vedr. hospitalsspildevand, der ikke har fået megen opmærksomhed tidligere, er der udarbejdet en særskilt handlingsplan for hospitalsspildevand ${ }^{57}$ og foretaget en intern evaluering af indsatsen. ${ }^{58}$

På lister over vandprojekter har man rubriceret de tilskud, der er gået til at etablere vandprojekter i Kina og Indien.

Projekter til at løse problemet med ballastvand er støttet i 3 situationer. Og membranprojekter har ligeledes modtaget tilskud. Et par projekter om renere dambrugsproduktion har også modtaget tilskud.

Der eksisterer ikke noget samlet overblik eller en samlet rubricering af tilskuddene på vand. Det kan man kun få ved at se listerne igennem. Det ville være noget nemmere at få et overblik, hvis der var lavet et sådant fagligt overblik med perspektivering af indsatsen.

\section{H) Luftforurening}

På området for luftforurening er der støttet 19 projekter, som har fået et samlet tilskud på 17 mio. DKK.

Under partnerskaber ovenfor er nævnt støttede projekter, som relaterer sig til skibe.

Hertil støttes en række projekter med brændeovne og fyringsanlæg.

I forbindelse med luftforurening kan man nævne en rapport, som Miljøstyrelsen har fået udarbejdet om danske virksomheder, der beskæftiger sig med teknologier, der reducerer luftforurening. ${ }^{59}$ Rapporten analyserer virksomhederne, som beskæftiger sig med luftforurening. Det er i langt overvejende grad en erhvervsfaglig rapport og ikke en miljøteknologisk rapport.

\footnotetext{
${ }^{57}$ By- og Landskabsstyrelsen: Handlingsplan for hospitalsspildevand, maj 2009, 5 sider.

58 Naturstyrelsen: Evaluering af Miljøministeriets handlingsplan for hospitalsspildevand, den 13. april 2011 4 sider.

59 Miljøstyrelsen: Kan man tjene penge på ren luft? - danske styrkepositioner inden for teknologier, der reducerer luftforurening, udarbejdet af FORA, Miljøprojekt nr. 1203, 2007, 39 sider.
} 


\section{I) Sundhedstruende forurening}

Der er støttet 5 støjprojekter til en samlet sum af i alt 3,1 mio. DKK.

Der er endvidere støttet 9 projekter, som har med udfasning af skadelige kemikalier at gøre. Det er alternative kølemidler, udfasning af PFOS, mindre skadelig træbeskyttelse etc.

I forbindelse med kemikalier kan man nævne, at Miljøstyrelsen har fået udarbejdet en rapport om danske styrkepositioner indenfor teknologier, der kan føre til substitution af problematiske kemikalier. ${ }^{60}$ Med sin fokus på eksisterende og mulige danske styrkepositioner på substitutionsområdet og vurdering af barrierer, samt forslag til erhvervsudvikling, må man sige, at rapporten er en erhvervsudviklingsrapport. På denne måde er det miljømæssige ikke langt fremme i rapporten. Man kunne også have lavet en rapport, som decideret beskrev muligheder for perspektivrig substitution i mængder og farlighed. Rapporten er dog værd at interessere sig for, idet den viser en række relevante detaljer og giver også spændende eksempler på konkrete substitutioner.

\section{J) Affald}

I handlingsplanen fra 2010 er der givet tilskud til 9 forskellige affaldsprojekter. De modtager i alt 6,3 mio. DKK i tilskud.

Projekterne vedrører forskellig oparbejdning eller bedre ressourceudnyttelse af affald.

I forbindelse med affald kan der gøres opmærksom på, at Miljøstyrelsen har udarbejdet en analyse af miljøteknologiske potentialer på affaldsområdet. ${ }^{61}$ Teknologier, som kan erstatte nogle af de eksisterende behandlingsmetoder, gennemgås. Det vurderes om de kan markedsføres ved ændrede reguleringsmæssige, økonomiske samt udviklingsmæssige aspekter. Rapporten beskæftiger sig i udpræget grad med teknologi og må som sådan siges at være en rigtig miljøteknologisk rapport med udgangspunkt i den teknologiske udvikling, og hvor denne bevæger sig hen ad koblet til affaldspolitikken. Rapporten bemærker et stort behov for fjernelse af administrative og reguleringsmæssige barrierer.

\subsection{Klima- og energiområdet}

Klima- og energiområdet er det område i Danmark, hvor der med afstand er den største fokus i form af offentlig økonomisk støtte og eksport etc., samt samspil mellem udvikling og regulering. Energiområdet har

\footnotetext{
${ }^{60}$ Miljøstyrelsen: Analyse af danske styrkepositioner inden for teknologier, der kan føre til substitution af kemikalier, Miljøprojekt nr. 1305, 2009, udført af Cowi, 92 sider.

61 Miljøstyrelsen: Miljøteknologi på affaldsområdet. Danske styrkepositioner og potentialer, Miljøprojekt nr. 1327, 2010, udført af Cowi, 81 sider.
} 
meget længe tiltrukket sig politisk opmærksomhed, fordi vedvarende energi, hovedsagelig vindmøller, har været et stort politisk indsatsområde siden 90'erne. Hertil er energiområdet centralt i klimasagen, fordi energiområdet udgør det område, hvor klimagasser lettest kan reduceres. Dog må man fremhæve, at regeringsskiftet til en borgerlig regering $\mathrm{i}$ 2001 skar betydeligt ned på den økonomiske støtte til f.eks. vindenergi.

Indtil regeringsskiftet i 2001 var klima placeret i Energistyrelsen, som var en styrelse under Miljø- og Energiministeriet. Fra 2001-2007 var klimapolitikken placeret i Miljøstyrelsen, og Energistyrelsen blev placeret i et Transport- og Energiministerium. Efter valget i efteråret 2007 blev der oprettet et Klima- og Energiministerium for at styrke klimasagen. Her blev den operationelle del af klimaområdet igen ført tilbage til Energistyrelsen. Energistyrelsen har dog i alle årene været den centrale aktør på energiområdet i relation til klimapolitikken, også i årene hvor klimapolitikken var placeret i Miljøstyrelsen.

\section{Regulering af klima- og energiområdet}

Kyotoprotokollen er det internationale reguleringsgrundlag for reduktionsmålene i udledningen af drivhusgasser i perioden 2008-12, og EU har forpligtet sig til at nedbringe sine udledninger til et niveau på $8 \%$ under niveauet for 1990. Af den samlede EU-forpligtelse har Danmark lovet at reducere sine udledninger med $21 \%$ i forhold til niveauet i 1990. EU har fastlagt, at reduktionerne skal ske ved anvendelse af medlemslandenes egne nationale virkemidler, samt et fælles EU kvotehandelssystem.

Som det er besluttet i EU, har Danmark, som de andre medlemslande, til opfyldelse af sine EU-klimaforpligtelser og dermed sine internationale forpligtelser udarbejdet en forsøgsallokeringsplan for årene 2005-2007, samt den endeligt bindende allokeringsplan for 2008-2012. ${ }^{62}$ Der følges jævnligt op på denne plan ved at vurdere, om den vil nå målet. Det er dermed meget nemt udefra at vurdere, hvordan det går med gennemførelsen af forpligtelsen. Energistyrelsen gør det selv, men også andre, f.eks. Tænketanken Concito udgiver i årene 2010-2012, hvert år en rapport om, hvordan det går. ${ }^{63}$

Den eksisterende energiaftale er indgået den 21. februar 2008 i et bredt forlig med partierne i Folketinget, bortset fra Enhedslisten. ${ }^{64}$ Den fungerer frem til udgangen af 2011. Denne aftale skal skabe bedre vilkår

\footnotetext{
62 Danmarks Nationale Allokeringsplan 2008-2012, 6. marts 2007, 88 sider.

63 Energistyrelsen: Basisfremskrivningen for Danmarks fremtidige energiforbrug og udledning af drivhu sgasser, 18. april 2011, og Tænketanken Concito: The Annual Climate Outlook of Denmark (ACO), maj 2010, (som dog på trods af titlen er på dansk), 178 sider.

${ }^{64}$ Aftale mellem regeringen (Venstre og Det Konservative Folkeparti), Socialdemokraterne, Dansk Folkeparti, Socialistisk Folkeparti, Det Radikale Venstre og Ny Alliance om den danske energipolitik i årene 2008-2011, 21. februar 2008, 4 sider.
} 
for vindmøller og anden vedvarende energi som f.eks. biomasse og biogas. Vedvarende energi skal i 2011 dække $20 \%$ af Danmarks energiforbrug. Der skal gives bedre afregningspriser på strøm fra vedvarende energi, og der skal rejses 400 MW havvindmøller i 2012.

Desuden skal der spares på energien, så at bruttoenergiforbruget $\mathrm{i}$ 2020 skal være faldet $4 \%$ i forhold til 2006. Det blev ligeledes besluttet, at der til forskning, udvikling og demonstration i energiteknologi skal afsættes 1 mia. DKK i 2010. Dette mål er nået, idet bevillingen for 2010 nåede op på 1,1 mia. DKK, hvilket også er beløbet afsat i 2011 .

Den eksisterende energiaftale kendetegner sig vel mest ved, at oppositionen ønskede at gå betydeligt længere i retning af øget indsats for vedvarende energi og energibesparelser. På trods af at dette ikke blev tilfældet ønskede oppositionen at være med, snarere end at stå udenfor. Og oppositionen ønskede ikke at binde sig længere end til og med 2011. Dansk Folkeparti har også som fast støtteparti for regeringen forsøgt at sikre, at regeringen ikke var for klimavenlig i tilgangen.

\section{Klimakommissionen}

I 2008 nedsatte regeringen en klimakommission, som fik til opgave at se på, hvordan Danmark kan gøre sig uafhængig af fossile brændsler i 2050. I september 2010 afleverede kommissionen en rapport på 100 sider med en baggrundsrapport på over 400 sider samt en lang række bilagsrapporter. ${ }^{65}$ Kommissionen bestod af 10 eksterne eksperter, heraf et antal fagligt stærke økonomer, og den var uafhængig af regeringen med sekretariatet placeret i Energistyrelsen.

Klimakommissionen har 40 anbefalinger, og her kan 3 af disse siges at være centrale: 1) en ny fossilafgift, så markedet bliver driver for udviklingen, 2) der skal ske energieffektiviseringer i samtlige bygninger i Danmark ved at etablere en opsparingskonto til hver bolig, og 3) kraftig udbygning af havvindmøller. En hovedlinje i anbefalingerne er, at man skal gå i gang med det samme.

En af de mest bemærkelsesværdige analyseresultater fra Klimakommissionens side er den økonomiske opgørelse af, hvad det koster at gøre Danmark uafhængig af fossile brændsler i 2050. Det viser sig, at det vil koste stort set det samme at lave en fuldstændig omstilling til et grønt energisystem, som det vil koste at lade være. Årsagen hertil er, at de nuværende energikilder vil blive dyrere på grund af stigende priser. Tilmed er det allerede påpeget, at det kan blive billigere endnu med over 15 mia. DKK, hvis man tillige opgør de sundhedsmæssige virkninger af elimineringen af fossile brændsler. Det har Klimakommissionen dog ikke medtaget.

65 Klimakommissionen: Grøn Energi - vejen mod et dansk energisystem uden fossile brændsler, september 2010, 98 sider, samt baggrundsrapport og bilagsrapporter. 
Umiddelbart efter at Klimakommissionen afleverede sit arbejde til regeringen i september 2010 blev arbejdet kritiseret af både medlemmer fra partier i regeringen og i oppositionen, givetvis ud fra hver deres positioner.

\section{Energistrategi 2050}

Man gik relativt hurtigt i gang med at lave et oplæg til en ny politisk aftale. Dette oplæg, Energistrategi 2050, blev præsenteret i februar $2011 .^{66}$

Energistrategi 2050 udstikker som mål, at Danmark i 2050 skal være uafhængigt af fossile brændsler, dvs. være uafhængig af kul, olie og gas. Efter sigende er det den første strategi, der klart udstikker detaljerede virkemidler til at opnå dette, både i Danmark, men også globalt. Samtidig vurderes finansieringen af virkemidlerne også.

Flere af tiltagene skal ske i løbet af kort tid. Inden 2020 skal anvendelsen af fossile brændsler i energisektoren reduceres med $33 \%$ i forhold til 2009. Andelen af vedvarende energi skal øges til $33 \%$ i 2020 og bruttoenergiforbruget skal i 2020 være faldet med $6 \%$ i forhold til 2006.

Energistrategi 2050 har fået en del kritik, bl.a. fordi man ikke formår at sætte noget ind over for landbrug og transport. Omvendt er det udtalt i forbindelse med Energistrategi 2050, at strategien ikke er en endelig strategi, men en begyndelse, hvor der skal justeres løbende.

Den 15. september 2011 var der valg i Danmark med det resultat, at oppositionen kom til magten og dannede regering. Oppositionen har hele tiden haft en betydelig mere positiv indstilling til klimaarbejdet og for tilvejebringelse af flere tilskudsmidler og bedre regulering til området for at fremme reduktion af klimagasser.

Det nye regeringsgrundlag har ganske meget med om klima og energi. ${ }^{67}$ Det slås fast, at hele Danmarks energiforsyning skal dækkes af vedvarende energi i 2050. Udslippet af drivhusgasser skal reduceres med 40 \% i 2020 i forhold til 1990 mod hidtil 30 \% Der skal udarbejdes en egentlig klimalov. En ny energiaftale skal hurtigst muligt på plads.

\section{Vores energi}

I slutningen af november offentliggjorde regeringen et nyt klima- og energiudspil, kaldet „Vores energi““ ${ }^{68}$ Udspillet bygger videre på den tidligere regerings udspil Energistrategi 2050, om end det har et højere ambitionsniveau. Reduktionen i samlet CO2 i 2020 skal være $35 \%$ og ikke kun $30 \%$, som foreslået tidligere. Vedvarende energi og vindandel skal øges i 2020. Ligesom reduktionen i bruttoenergiforbruget 2020 skal

\footnotetext{
${ }^{66}$ Regeringen: Energistrategi 2050 - fra kul, olie og gas til grøn energi, februar 2011, 65 sider, plus Sammenfatning på 29 sider, samt en række forskellige bilag.

${ }^{67}$ Regeringen: Et Danmark, der står sammen, Regeringsgrundlag, oktober 2011, 76 sider.

68 Regeringen: Vores Energi, november 2011, 41 sider.
} 
øges igen. Naturligvis bliver den nye plan også dyrere end den tidligere plan med et beløb på samlet 2 mia. DKK.

Igen skal der forhandles om et energiforlig, som også tidligere. Dette forlig var ikke på plads ved afslutningen af dette projekt, men må forventes at blive forhandlet på plads i begyndelsen af 2012.

\section{Energiforskning, -udvikling og demonstration}

Danmark har allerede siden den første energikrise fra 1973-74 afsat ganske mange midler årligt til energiforskning, ikke mindst vedvarende energi. Bl.a. skal det store og tidligere engagement i vindmøller ses på baggrund af en forkærlighed for vedvarende energi og ikke for forbedrede miljøforhold. Så energiforskningen har en lang tradition i Danmark.

\subsubsection{Det Energiteknologiske Udviklings-og Demonstrationsprogram, EUDP}

Det seneste store spring fremad på energiområdet må siges at være EUDP, som med stor politisk opbakning, også i forhold til klimapolitikken, løfter energiområdet op i en højere kategori af indsats på området for miljøeffektiv teknologi. Derfor er der fokus på netop dette program i denne gennemgang.

\section{Lovgrundlag}

I marts 2007 fremsatte den daværende transport- og energiminister et lovforslag om et Energipolitisk Udviklings- og Demonstrationsprogram, kaldet EUDP. Lovforslaget blev vedtaget uden ændringer i juni 2007 som EUDP-loven. Loven indeholder programmets formål, organisation, tilskudsmuligheder mv. Loven følges af en række bekendtgørelser, bl.a. i form af detaljer om tilskud og en forretningsorden for EUDPs bestyrelse, samt om forskellige ikrafttrædelsestidspunkter af dele af loven. Loven afløser Lov om statstilskud til forskning og teknologisk udvikling på energiområdet, kaldet Energiforskningsprogrammet (EFP). ${ }^{69}$

Bestyrelsen og sekretariat begyndte at arbejde umiddelbart efter vedtagelsen, mens selve programmet startede i januar 2008.

Som sit særlige indsatsområde har EUDP tilskud til demonstrationsanlæg, hvorfor det været afgørende at få EU-kommissionens accept af programmet, da dette område ligger tættere på konkurrenceforvridning end forskning. EU-kommissionens rammebestemmelser for statsstøtte til forskning, udvikling og innovation af januar 2007, samt EU-

${ }^{69}$ Forslag til lov og lov om et Energiteknologisk Udviklings- og Demonstrationsprogram. 
kommissionens godkendelse af EUDP-programmet af den 12. december 2007 indgår følgelig som retsgrundlag for loven. ${ }^{70}$

I oktober 2010 fremsættes en revision af EUDP-loven for herved at omfatte et "Green Labs program" i form af muligheder for at etablere faciliteter, hvor virksomheder kan demonstrere og teste nye klimateknologier under realistiske omstændigheder. Dette lovforslag blev vedtaget $\mathrm{i}$ december $2010 .^{71}$

\section{EUDP programmet}

Det var manglen på midler til demonstrationsanlæg, der var det vigtigste i etableringen af EUDP. EUDP blev dermed etableret for at fremme demonstration og markedsintroduktion af ny energiteknologi. Det eksisterende Energiforskningsprogram (EFP) blev med loven lagt sammen med EUDP. Formålet er at understøtte de energipolitiske målsætninger om forsyningssikkerhed, hensyn til det globale klima og et renere miljø samt omkostningseffektivitet.

EUDPs konkrete aktiviteter er at:

- Yde tilskud til udvikling og demonstration

- Fremme samarbejdet mellem offentlige og private aktører

- Styrke samspillet med internationale aktiviteter og programmer inden for energiteknologi

Der lægges endvidere vægt på udarbejdelsen af strategier, der omfatter hele udviklingskæden fra forskning til markedsintroduktion, som grundlag for indsatsen. Denne strategiske tilgang varetages af bestyrelsen og gennemføres af EUDP sekretariatet i Energistyrelsen. ${ }^{72}$

Blandt de teknisk faglige aktiviteter som EUDP støtter nævnes følgende:

- Biomasseteknologier og -systemer til transport og energi

- Vindkraft og andre vedvarende energiteknologier, som f.eks. bølgekraft og solenergi

- Brint og brændselscelleteknologier

- Lavenergibygninger

- Energieffektive løsninger, herunder i slutforbruget, samt fleksibelt energiforbrug

- Samlede energisystemer (integration af teknologier), herunder transport af energi

- Mere effektive indvindingsmetoder for olie og gas

\footnotetext{
70 EU-kommissionen: Fællesskabets rammebestemmelse for statsstøtte til forskning og udvikling og innovation af den 30. december 2006, C 323/01, og EU-kommissionens godkendelse af EUDP den 12. december 2007.

${ }^{71}$ Revision af EUDP-loven (Green Labs DK-programmet) oktober 2010.

72 Et eksempel er Forsknings- og udviklingsstrategi for biogas, august 2009, 19 sider.
} 
- Mere effektiv og miljøvenlig produktion i øvrigt (el og varme), herunder CO2-deponering

I støtten til disse aktiviteter lægges der stor vægt på netværk, konsortier og partnerskaber.

For udviklings- og demonstrationsprojekter skal egenfinansieringen typisk være på minimum $50 \%$

Med Green Labs, som en engelsk skrivemåde for grønne teknologilaboratorier eller testfaciliteter, bliver det muligt at støtte med revisionen af EUDP-loven i december 2010.

Midlerne til EUDP kommer fra en såkaldt Globaliseringspulje. I første omgang blev der afsat ca. 700 mio. DKK til årene 2007-2010, heraf skulle 200 mio. DKK gå til udvikling af 2. generations biobrændstof. Der blev tilvejebragt yderligere 360 mio. DKK til årene 2009 og 2010.

Til Green Labs afsættes der på finansloven afsat 210 mio. DKK over 3 år til testfaciliteter.

\section{Organisation}

I 2010 var der 13 medarbejdere og en chef, som varetog sekretariatet for EUDP og Green Labs. Udover at administrere bevillingen til EUDP betjener sekretariatet bestyrelsen og har opgaver i relation til energiteknologi i Energistyrelsen og også i forhold til Klima- og Energiministeren. 1,5 $\%$ af programmets bevilling er afsat til finansiering af sekretariatet. Bestyrelsen har dog fået udvirket, at 2 ekstra årsværk blev bevilget i 2010, og disse er forlænget i 2011.

\section{Energiprogrammernes udviklingskæde}

Danmark har støttet energiområdet forskningsmæssigt længe før etableringen af EUDP i 2007. Der er i 2008, 2009, 2010 og 2011 udgivet en samlet publikation over statslige tilskud til energiforskning, -udvikling og demonstration, kaldet Energi 2008, (2009, 2010, 2011) forskning, udvikling og demonstration. Det er beretningerne over aktiviteterne i det pågældende år. Især publikationerne fra 2010 og 2011 løfter sig i forklaringsevne ved at komme rundt om energiprogrammerne og sammenhænge mellem programmerne og kan virkelig anbefales. ${ }^{73}$

Den smalle forståelseslinje deler op mellem forskning, udvikling og demonstration, mens den længere forståelseslinje deler op mellem grundforskning (baggrundsforskning), forskning (anvendt og strategisk forskning), udvikling, demonstration, produktudvikling, markedsmodning. Hidtil har midlerne til forskning været til stede, men kun i mindre grad til demonstration. Først med EUDP kommer der flere midler til

\footnotetext{
${ }_{73}$ Energi 2008, 2009, 2010 og 2011, forskning, udvikling og demonstration, bl.a. Energi 2011, maj 2011, 160 sider. 
demonstration. For året 2010 var der afsat over 1 mia. DKK til den samlede indsats til energiprogrammerne, og EUDP havde lidt over 400 mio. DKK heraf. For 2011 fastholder EUDP sit niveau fra 2010 med 400 mio. DKK i tilskud.

EUDP adskiller sig væsentlig fra energiforskningsaktiviteterne i regi af det Strategiske Forskningsråd (DSF) under Videnskabsministeriet, der lægger tyngden på egentlige forskningsaktiviteter på universiteterne, inkl. uddannelse af phd'ere. I forhold til Højteknologifonden adskiller EUDP sig ved at være en integreret del af energipolitikken og erhvervsudviklingen på energiområdet, mens Højteknologifonden fremmer den teknologiske udvikling generelt.

\subsubsection{EUDPs projektaktiviteter ${ }^{74}$}

\section{Biomasse}

På biomasse området har EUDP valgt at prioritere flere forskellige projekter, der videreudvikler og demonstrerer forgasning af gylle. Dette er godt $\mathrm{i}$ tråd med den politiske udmelding om at udnytte halvdelen af energiindholdet i husdyrgylle frem mod 2020. De store anlæg skal kunne køre alene på grundlag af gylle uden tilsætning af f.eks. organisk affald fra fødevareindustrien. Der er ikke tilstrækkelig organisk affald i Danmark.

Et af projekterne RETROGAS ved Nordic BioEnergy benytter en ny separationsteknologi og et nyt ultrafiltreringsanlæg for den flydende del af gyllen og enzymbehandling af den faste del. Formålet er at vise, at produktionen er rentabel, selv når der kun anvendes gylle. I et andet projekt forsøger firmaet Xergi at nå samme mål med en komposteringsbehandling af den faste del af gyllen. Og endelig er der givet projektstøtte til at afprøve om forsepareret fiberfraktioner og lagerfaste energiafgrøder kan øge og regulere biogasproduktion på en række eksisterende biogasfællesanlæg.

\section{Biobrændstoffer}

Inbicon, som er datterselskab af DONG Energy, begyndte i foråret 2010 at producere 2. generations bioethanol med halm som brændsel fra sit demonstrationsanlæg i Kalundborg. Anlæggets årlige produktion på 5 mio. liter aftages af benzinselskabet Statoil. Restprodukter i form af ligninpiller bliver brugt i stedet for kul på det nærliggende kraftværk i Asnæs. Dette teknologiske gennembrud har vagt international opsigt, og der er indgået internationale licensaftaler i bl.a. USA og Sydøstasien. Enzymerne

${ }^{74}$ Nedenstående beskrivelse af EUDPs aktiviteter er beskrevet med udgangspunkt i de årlige beretninger nævnt i ovenstående note. 
kommer fra de danske producenter Novozymes og Danisco Genencor, som også udvikler mere effektive og billigere produkter.

Anlægget i Kalundborg har over en årrække modtaget danske forsknings-, udviklings- og demonstrationsmidler på ca. 76 mio. DKK til bl.a. en samlet anlægsudgift på 325 mio. DKK. EUDP har støttet Inbicon med ca. 70 mio. DKK. Der arbejdes på en række projekter om at forbedre den såkaldte IBUS-proces, som anvendes. Det er forsøg på også at omdanne pentosesukkeret til bioethanol, som gennemføres af forskningsvirksomheden Terranol. Det drejer sig om at udvikle et kontinuerligt indfødningssystem, genanvende enzymer mv. som led i at nedbringe produktionsomkostninger for herved at gøre bioethanolen mere konkurrencedygtig i forhold til konventionel benzin. Som led i denne udviklingsstrategi har Inbicon modtaget midler fra EU (68 mio. DKK) til at bringe produktionsomkostningerne ned i et projekt kaldet Kacelleprojektet (Kalundborg Cellulosic Ethanol Project). Målet er et fuldskala anlæg, som kan producere på 400.000 tons halm om året.

Det andet store projekt, som EUDP er gået ind i, er BioGasols planlagte anlæg på Bornholm. I første omgang er der ydet EUDP tilskud på 27 mio. DKK til fase 1. Her skal den såkaldte MaxiFuels-proces køre i et demonstrationsanlæg med ca. samme kapacitet, som anlægget i Kalundborg. EUDP har givet et betinget tilsagn til selve anlægget på 78 mio. DKK.

Indenfor biobrændstoffer har EUDP også givet støtte på 10 mio. DKK til SCF-Technologies, hvor spildevandsslam, affald fra fødevareproduktion og restprodukter fra bioethanol kan omdannes til bioolie. Målet er et demonstrationsanlæg, som skal opføres ved Nordjyllandsværket. Til dette demonstrationsanlæg er der søgt om støtte hos EUDP.

Der kan også nævnes et projekt, hvor Haldor Topsøe og Teknologisk Institut har modtaget 7 mio. DKK til at omdanne 2. generations bioethanol til dimetylether, der kan anvendes til at øge virkningsgraden i en dieselmotor markant.

\section{Brint og brændselsceller}

Brændselsceller består af en ionledende elektrolyt, som på siderne er omgivet af en elektronledende katode og en anode, der forsynes med henholdsvis iltholdig gas (luft) og brintholdigt gas (brændstof). Brændslet omdannes i cellen elektrokemisk direkte til jævnstrøms elektricitet. Brændselsceller kan stables i serieforbundne systemer og kaldes stakke. Herved fås spændinger, som kan bruges til mange formål.

Udviklingen af brændselsceller har været koncentreret om 4 forskellige typer og benævnes efter det materiale, der benyttes som elektrolyt. Indsatsen i Danmark har været koncentreret om PEM-cellen (Proton Exchange Membrane Fuel Cell) og SOFC-cellen (Solid Oxide Fuel Cell, fastoxid). Cellerne inddeles ofte efter deres arbejdstemperatur.

De første anlæg er introduceret indenfor specielle nichemarkeder som nødstrømsanlæg og nichetransport, f.eks. gaffeltrucks. De forventes anvendt både til stationære formål som kraftvarme- og nødstrømsanlæg 
og til vej- og nichetransport. En bredere anvendelse forventes at komme fra 2015-2020. SOFC-cellen forventes at blive et økonomisk interessant alternativ til decentral kraftvarmeproduktion. PEM-celler er velegnede til transportområdet.

Topsoe Fuell cell åbnede i 2009 en fabrik med en årlig kapacitet på 5 MW af produktionen af SOFC-celler. EUDP har støttet virksomheden med at udvikle, effektivisere og billiggøre produktionsprocessen. Der er tale om et stort projekt $\mathrm{i}$ form af produktionsoptimering af dansk brændselscelleteknologi med en række danske deltagere.

Inden for lavtemperatur PEM (LT-PEM) brændselsceller er målet også at gøre omkostningerne billigere.

De danske virksomheder er forholdsvis langt fremme, idet man har fået $15 \%$ af midlerne i EU-programmerne til området i flere år. Branchen står også ganske velorganiseret og har udarbejdet flere strategier for de enkelte områder.

\section{Bølgekraft}

Der arbejdes intensivt i bølgeenergibranchen på at udvikle et fælles designgrundlag for anlæg til udnyttelse af bølgeenergi. Anlæggene skal gøres mere pålidelige og bringe prisen på den producerede energi ned på et konkurrencedygtigt niveau. Et af værktøjerne er ved simuleringer at kunne identificere den totaløkonomiske optimale balance mellem sikkerhedsniveau og anlægsomkostninger. Andre værktøjer skal skabe mulighed for at vurdere ekstrembelastning og løbende belastning.

EUDP har ydet støtte til flere koncepter for bølgeenergi på forskellige udviklingstrin. Wave Star har fået støtte til at opskalere og demonstrere sin bølgekraftmaskine på $500 \mathrm{~kW}$. Testning har vist god succes for en forbedring af modellen.

En række andre virksomheder: Wave Dragon, LEANCON Wave Energy, Wavenergifyn og DEXA Wave Energy har udviklet koncepter for anvendelse af bølgekraft og er på vej mod afprøvning i pilotprojekter eller større demonstrationsprojekter. Wave Star er længst fremme med sin teknologi.

Man kan måske bemærke, at der er en del kritikere af projekter med bølgekraftenergi. Et udviklingsforløb, hvor bølgekraften virkelig slår igennem, synes at være langt ude i fremtiden. Det er også nævnt, at Danmark ikke har særligt gode afprøvningsforhold tæt på land, fordi der er så lavvandet. Samlet set synes bølgekraft ikke at være så perspektivrigt i Danmark.

\section{Effektiv energianvendelse}

EUDP satser på energirenoveringer på grund af det store potentiale, som stadig kan nås for en mere effektiv energianvendelse. EUDP støtter flere projekter, der søger at udvikle og afprøve nye måder eller koncepter for energirenoveringer i enfamiliehuse og etagebyggeri. Der satses både på nye teknologiløsninger og økonomisk fordelagtige løsninger, så der er stor mulighed for, at de fører til konkrete energibesparelser. 
Herudover støttes projekter med intelligente byggematerialer, varmepumper til nye anvendelser, nye lovende ventilationskoncepter. EUDP er også med til at støtte Danmarks første C02-neutrale offentlige bygning - Green Light House ved Københavns Universitet. Et betydeligt antal projekter er blevet støttet.

DTU (Danmarks Tekniske Universitet) Byg søger at systematisere de løbende erfaringer med energirenovering, så det skulle være muligt at få et overblik hér. Ydermere samler det strategiske partnerskab for energieffektivt byggeri, EnergiBYG, alle væsentlige aktører og er ved at lave en samlet strategi for energieffektivt byggeri, inkl. vurderinger af markedspotentialet for energirenovering.

\section{Fremtidens intelligente energisystemer}

EUDP støtter sammen med energiprogrammet ForskEL med betydelige beløb fremtidens intelligente energisystemer ved at gøre øen Bornholm til et fuldskala testcenter. Øen er særlig ved at have en relativ stor og vedvarende elproduktion fra vedvarende energikilder og kan også i perioder være selvforsynende med energi. Herved kan danske kompetencer indenfor intelligent styring af elproduktion og -forbrug afprøves i fuldskala.

Et EcoGrid projekt er startet på øen med deltagelse af en række aktører, herunder også flere udenlandske. Der skal udvikles modelværktøjer og driftsstøtteværktøjer til elsystemet, så det kan håndtere store mængder el fra vedvarende anlæg. I juli 2011 annonceres, at der er fundet finansiering på 138 mio. DKK til udvikling af fremtidens intelligente elsystem. EUDP bevilger 32 mio. DKK og Green Lab bevilger 15 mio. DKK. Private investorer bevilger omkring 30 mio. DKK og Danmarks Tekniske Universitet bevilger de resterende midler. Projektet kaldes PowerLabDK og skal teste og udvikle Smart Grid-teknologier til fremtidens intelligente elsystem. Hermed bliver det muligt at integrere en varierende mængde strøm fra vindmøller i energisystemet. Den eksperimentelle platform giver Danmark gode muligheder for at være i front internationalt med afprøvning af de moderne systemer. ${ }^{75}$

\section{Solenergi}

EUDP har bl.a. med en bevilling på knap 10 mio. DKK støttet videreudvikling og demonstrationsanlæg af solceller produceret i plastik. Det drejer sig om at demonstrere plastsolceller som et kommercielt alternativt til traditionelle solceller baseret på silicium. Produktionsprocessen skal industrialiseres for at demonstrere en række nicheprodukter, der bliver økonomisk interessante med plastcellernes store fleksibilitet og

75 Pressemeddelelse fra Energistyrelsen den 4. juli 2011: 138 mio. DKK til udvikling af fremtidens intelligente elsystem. 
lave produktionspris. Målet er at fremme plastceller i en dansk sammenhæng ved design, fremstilling og markedsføring.

EUDP midler har også fremmet store solvarmeanlægs brug af varmepumper, samt kombinationer af sol- og fjernevarmedrevne adsorptionsvarmepumper og jordlager.

\section{Vindenergi}

En udfordring for vindmølleindustrien er at gøre havvindmøller mere konkurrencedygtige sammenlignet med andre former for elproduktion. Møllerne skal gøres mere produktive og reducere driftsomkostningerne ved at udvikle mere stabile vindmølledele, som har mindre behov for vedligeholdelse og længere levetider. Til at fremme denne strategi har EUDP støttet en række projekter.

\section{Green Labs}

I maj 2011 bevilger bestyrelsen for Green Labs programmet 129 mio. DKK til 4 testcentre, hvor virksomheder kan teste og demonstrere nye klima- og energiløsninger med globalt markedspotentiale. Dette er de første midler, som er bevilget fra Green Labs programmet.

Der bevilges 87 mio. DKK til Lindoe Nacelle Testing, et testcenter for store naceller (vindmøllehuse) på et tidligere skibsværft, Lindø-værftet på Fyn. Formålet er at funktions- og udholdenhedsteste store havvindmøller. Bag centret er en række danske vindmølleproducenter, investorer og universiteter, dvs. en del af de globalt førende inden for havvindmøller.

Der bevilges 25 mio. DKK til Green Lab for Energy Efficient Buildings. Der etableres et testcenter i samarbejde mellem Teknologisk Institut og DTU Byg, som skal teste energieffektive bygnings- og installationskomponenter. Det kan også teste kombinerede enheder indenfor solvarme, solceller, varmepumper og ventilation under standardiserede forhold. Der vil endvidere blive mulighed for at teste alternative bygnings- og isoleringsmaterialer.

Der bevilges 15 mio. DKK til et testcenter til Smart Grid-komponenter for at kunne integrere en varierende mængde strøm fra f.eks. vindmøller i el-systemet. Dette er også nævnt ovenfor under Fremtidens intelligente energisystemer.

Endelig bevilges der 2 mio. DKK til et testcenter for grønne gasser, f.eks. biogas, som sendes ud på nettet. Centret hedder Green Gas Test Center, og det skal sikre, at biogasserne har en tilstrækkelig kvalitet til at kunne bruges. 


\section{Evaluering af EUDP's aktiviteter}

På trods af at EUDP først er blevet igangsat i 2007 med start på projektmidlerne i januar 2008 er der allerede udarbejdet en evaluering af resultater og effekter i september $2011 .{ }^{76}$ Dermed er der ikke tale om en evaluering af selve programmet, men af resultater og effekter. Evalueringen konkluderer, at EUDP i høj grad opfylder sit formål om at udvikle klimavenlige og effektive teknologier og bringe disse frem til markedet. Blandt deltagerne i projekterne forventer $70 \%$ at bringe nye energiteknologier frem til markedet. Dette er allerede sket i en tredjedel af de afsluttede projekter, selvom EUDP's støtte hører op inden egentlig markedsføring. Generelt ses positive effekter på skabelse af arbejdspladser, øget indtjening og bedre eksportmuligheder.

EUDP har i de første 4 år støttet 600 virksomheder og videninstitutioner $\mathrm{i}$ at skabe energiteknologisk udvikling for 1,8 mia. DKK, hvoraf EUDP's investering har udgjort ca. halvdelen. I perioden har EUDP støttet 175 projekter med ca. 900 mio. DKK. EUDP har i overvejende grad støttet mindre virksomheder, idet disse har fået $1 / 3$ af tilskudsmidlerne og deltager i næsten halvdelen af projekterne. Evalueringen indeholder også 10 cases, hvor der i analysen gås tæt på virksomhederne og deres situation, vilkår, muligheder og fremtid.

På denne baggrund må det siges, at EUDP er et ret succesrigt program. Enkelte projekter viser sig dog også ikke at føre til de forventede resultater og må derved siges at være fiaskoer. Kort opsummeret må evalueringen siges at vise at:

- Projekterne kan siges at bidrage til Danmarks klima- og energipolitiske målsætninger

- Der skabes tilfredsstillende teknologiske resultater i projekterne

- Mange projekter genererer vækst og arbejdspladser

- Der er tale om et smidigt og virksomhedsrettet program

- Vidensoverførsel fra videninstitutioner til erhvervsliv fremmes

- Der ses en stor tilskyndelseseffekt på de støttede projekter

- Projekter har generelt en god projektstyring og tilfredsstillende fremdrift

76 Oxford Research: Evaluering af Energiteknologisk udviklings- og demonstrationsprogram, EUDP 20072010, september 2011, 78 sider, Pressemeddelelse af den 19. september 2011, samt faktaark. 


\subsection{Miljøeffektive landbrugsteknologier}

Danmark har over en årrække arbejdet med at begrænse landbrugets miljøpåvirkning. Der synes at være en stadig kamp mellem effektiv landbrugsproduktion og en miljømæssig acceptabel produktion, hvor miljøkrav har vanskeligt ved at blive gennemført. Både Fødevareministeriet (Landbrugsministeriet) og Miljøministeriet har brugt mange kræfter på at finansiere projekter, regulere etc. for at gøre landbruget mere miljøvenligt.

Reguleringsmæssigt er der sket en væsentlig nyændring ved gennemførelsen af husdyrloven, som en hel ny reguleringstilgang til miljøgodkendelse af husdyrbrug. ${ }^{77}$ Med det nye reguleringskoncept gik man fra den gamle godkendelsesordning, hvor der blev set på hvert landbrug for sig efter en lang række parametre, til en model, hvor man forsøger at betragte landbrug nærmest som industrivirksomheder og regulerer efter teknologier. Det nye er primært teknologitilgangen, hvor man opstiller teknologikrav til landbrugene. Miljøstyrelsen, som administrerer husdyrloven, har udarbejdet en officiel teknologiliste. Teknologilisten er en vejledende liste over teknologi, der kan anvendes i miljøgodkendelser. ${ }^{78}$ Den optager navngivne teknologiske produkter og angiver leverandører. Teknologier for alle miljø- og geneparametre, der vurderes i miljøgodkendelserne, kan optages. Naturligvis er der særlig fokus på ny teknologi. Eksempler på teknologier er rubriceret under staldindretning, luftrensning, foderadditiver, opbevarings- og udbringningsteknologi.

For at styrke verifikationen af landbrugseffektive miljøteknologier er der udarbejdet et system til Verifikation af miljøeffektive landbrugsteknologier - VERA. ${ }^{79}$ Der har ofte været stor usikkerhed om teknologiers effektivitet i forhold til landbrugets miljøforhold. Derfor har landbruget været tøvende med at investere i ny teknologi. Ligeledes har myndigheder været tøvende med at godkende ansøgninger om miljøgodkendelser, hvor nye teknologier indgik. Igennem et offentligt styret system som VERA vil Miljøstyrelsen forsøge at tilvejebringe bedre sikkerhed. Der er på dansk initiativ indgået et tæt samarbejde med det hollandske og det tyske miljøministerium om VERA, og der er etableret et internationalt sekretariat, som er beliggende i Danmark. Der er bl.a. udarbejdet 5 testprotokoller for teknologier på 5 forskellige områder: luftrensning, staldteknologi, udbringningsteknologi, opbevaring af husdyrgødning, og separationsteknologi. Ved en positiv test kan producenter opnå udstedelse af VERA verifikater.

\footnotetext{
77 Lov nr. 1572 af den 20. december 2006 om miljøgodkendelse m.v. af husdyrbrug.

78 Teknologilisten, som opdateret i marts 2011.

79 Miljøstyrelsens hjemmeside om VERA og Miljøstyrelsen: VERA - Verifikation af miljøeffektive landbrugsteknologier nationalt og internationalt.
} 
Der er naturligvis langt flere detaljer, end der er plads til at beskrive her. Man må konstatere, at der er tale om et system under udvikling, som bliver stadig mere overbevisende i sin styrke og implementeringskraft. Oprindelig var den nye husdyrlov tænkt, som en mere simpel tilgang, men hurtigt er den også blevet administrativ tung. Der er bevilget 125 mio. DKK ekstra til sagsbehandling hovedsageligt i kommunerne, som står for miljøgodkendelserne, for at give kommunerne mere sagsbehandlingsstyrke på området. Der tegner sig dog nu et teknologisk godkendelsessystem, som fremover kan løse en stor del af landbrugets miljøproblemer, i og med at der er indbygget krav om løbende teknologiløft i husdyrbrugene.

I den første handlingsplan for miljøeffektiv teknologi blev det beskrevet, hvor mange midler, der er afsat til miljøeffektive landbrugsteknologier. Fødevareministeriet, Miljøministeriet og landbrugserhvervet har aftalt at bruge 45 mio. DKK fra Fødevareministeriet, 45 mio. DKK fra Miljøministeriet sammen med 90 mio. DKK fra landbrugserhvervet via de særlige promilleafgiftsfonde. Disse midler kobles til 75 mio. DKK fra EU's landdistriktsmidler. Som nævnt ovenfor i alt 255 mio. DKK. ${ }^{80}$

Af de 45 mio. DKK fra Miljøministeriet blev de 15 mio. DKK overført til Fødevareministeriet til støtte til udvikling, demonstration og investeringer i miljøeffektive teknologier under Landdistriktsprogrammet. 9 mio. DKK blev anvendt til opbygning af det europæiske forsknings- og udviklingsnetværk „ICT and Robotics in Agriculture and Related Environmental Issues", som finansierer dansk deltagelse i international forskning på landbrugsområdet. 16,5 mio. DKK af de resterende 21 mio. DKK er anvendt på det videre arbejde med etablering af VERA - Verifikation af miljøeffektiv teknologi til landbrugsproduktion. I samarbejde med tyske og hollandske partnere er der udarbejdet en VERA testprotokol, som teknologier skal testes efter, før det kan afgøres om de kan optages på husdyrlovens teknologiliste. De sidste 4,5 mio. DKK er anvendt på at udarbejde BAT (bedst tilgængelig teknologi) rapporter, der informerer om teknologi, som kan anvendes til implementering af krav om anvendelsen af BAT i husdyrproduktionen, samt vurderinger af ansøgninger om optagelse af teknologier på teknologilisten.

\section{Grøn vækst i dansk landbrug}

I april 2009 udsendte regeringen sit oplæg til Grøn Vækst, en grøn vækstvision for natur, miljø, klima og landbrug. ${ }^{81}$ Der er tale om en grøn vækststrategi for landbruget, så dansk landbrug kan fortsætte sin produktion, men samtidig leve op til en række miljø- og klimamæssige krav, som regeringen ikke tidligere har fået gennemført tilstrækkelig effektivt. En række

\footnotetext{
80 Der henvises til Miljøstyrelsen: Redegørelse for regeringens indsats for Miljøteknologi, oktober 2009.

81 Regeringen: Grøn Vækst, april 2009, 49 sider.
} 
konkrete initiativer skal gennemføres: bl.a. en ny kvoteordning for kvælstofudledning, etablering af 50.000 hektar randzoner og 13.000 hektar vandområder og ådale, omlægning af pesticidafgiften for at begrænse belastningen, reduktion på 700.000 tons $\mathrm{CO} 2$ om året, etablering af 75.000 hektar ny natur mv. Samtidig skal der satses på landbruget som leverandør af grøn energi, fremme økologi mv. Der skal altså gennemføres reduktioner af udledninger af kvælstof og fosfor, drivhusgasserne skal begrænses, skabes mere biogas, skabes mere økologi, og etableres mere natur, samtidig med at der kan komme flere dyr pr. bedrift.

En aftale om Grøn Vækst indgås i juni 2009 mellem regeringen og Dansk Folkeparti. ${ }^{82}$ Den følger stort set linjerne i oplægget. Samlet set er dette initiativ udtryk for en radikal nytænkning på området. På intet tidspunkt har man været så langt fremme med regulering af landbruget, primært fordi den hidtidige regulering ikke har virket tilstrækkelig effektivt. Der er tilmed afsat 13,5 mia. DKK til investeringer, en fordobling af den hidtidige indsats. Midlerne skal bl.a. gå til et Grønt Udviklings- og Demonstrationsprogram (GUDP), som har til formål at give tilskud til perspektivrige projekter for at fremme grøn vækst. Hermed er der skabt en ny og mere sammenhængende organisering af forsknings- og innovationsindsats på landbrugsområdet, inspireret af EUDP på energiområdet.

Med Grøn Vækst aftalen oprettes bl.a. følgende tilskudsmuligheder:

- En tilskudspulje på 145 mio. DKK årligt i perioden 2010-2015 til anvendelse af nye miljø- og klimavenlige teknologier i det primære landbrugserhverv

- En igangsætningspulje til etablering af biogasanlæg mv. på 85 mio. DKK årligt i perioden 2010-12

- En igangsætningspulje til økologiske biogasanlæg på 15 mio. DKK årligt i perioden 2010-12

- En tilskudspulje på 100 mio. DKK i perioden 2010-12 målrettet avancerede recirkuleringsteknologier i akvakulturerhvervet

Samlet set må det vurderes, at den danske landbrugsplan for grøn vækst kun i mindre grad er udtryk for ægte grøn vækst. Der er mange usikkerheder i gennemførelsen, hvilket som så ofte før har været et handicap i forhold til regulering af landbruget. Grøn vækst titlen er snarere udtryk for en smart titel i denne sammenhæng og er ikke overbevisende for en langsigtet måde at løse forholdet mellem produktion og miljøbelastning $\mathrm{i}$ landbruget.

Status for Grøn Vækst aftalen på landbrugsområdet er, at samtlige miljøtiltag har meget vanskeligt ved at komme igennem, mens skattelet-

82 Aftale om Grøn vækst, 16. juni 2009, 18 sider. 
telse til landbruget og tilskudsmidlerne er tilvejebragt. Tilmed udskød miljøministeren i februar 2011 også opfyldelsen af vandplanerne til 2027 for så vidt angår reduktionen af 10.000 tons kvælstof. ${ }^{83}$ Danmark er allerede omtrent 2 år forsinket med vandplanerne, som skulle have været færdige i december 2009, men endnu ikke er endelig vedtaget. EU kommissionen har indbragt Danmark for EF-domstolen for at bryde vandrammedirektivet.

Under den nye regering fra oktober 2011 har miljøministeren valgt at færdiggøre vandplanerne for at komme videre på området.

\section{Grønt Udviklings- og Demonstrationsprogram, GUDP}

Som aftalt i Grøn Vækst aftalen påbegyndte man udarbejdelsen af en lovgivning for at skabe et udviklingsprogram efter forbillede af EUDP på energiområdet.

Allerede i juni 2009 blev der afholdt en stor workshop med inddragelse af over 100 eksperter. Resultaterne fra workshoppen er gengivet $\mathrm{i}$ en opsamlingsrapport. ${ }^{84}$ Der peges på 8 udfordringer for dansk landbrug i fremtiden:

- En mere miljøeffektiv planteproduktion

- En mere CO2-neutral energiproduktion i landbruget

- En mere ressourceeffektiv husdyrproduktion (husdyr, sundhed, dyrevelfærd og klima/lugt)

- En mere miljøeffektiv økologisk produktion

- Større værditilvækst (bredt) i fødevaresektoren

- Bedre fødevaresikkerhed, ernæring og sundhed

- Bedre konkurrenceevne i fødevaresektoren

- Et mere ressourceeffektivt fiskeri og miljørigtig akvakultur

GUDP-loven blev fremsat som lovforslag i september 2009 og endelig vedtaget den 17. december 2009. ${ }^{85}$ Ideen er at skabe en sammenhængende forsknings- og innovationsindsats på fødevare-, jordbrugs-, og fiskeri- og akvakulturområdet. Formålet er at udvikle landbrugssektoren samtidig med, at der sikres et højt niveau inden for følgende områder:

- Klima-, miljø- og naturbeskyttelse

- Dyrevelfærd

\footnotetext{
83 Pressemeddelelse fra Miljøministeren den 9. februar 2011, samt et notat fra Miljøministeriet og Fødevareministeriet: Implementering af vandrammedirektivet og nitratdirektivet i Nederlandene, Slesvig-Holsten og Danmark, den 7. februar 2011, 6 sider.

${ }^{84}$ Ministeriet for Fødevarer, Landbrug og Fiskeri: Et Grønt Udviklings- og Demonstrationsprogram. Opsamling fra Fødevareministeriets Workshop om GUDP, 18. juni 2009.

85 Forslag til Lov om Grønt Udviklings- og Demonstrationsprogram fremsat den 8. oktober 2009, og Lov om Grønt Udviklings- og Demonstrationsprogram nr. 1502 af 27. december 2009.
} 
- Fødevaresikkerhed og sundhed

De midler, der er til rådighed skal anvendes til udviklings- og demonstrationsprojekter, samt forskningsprojekter, som kan fremme sådanne projekter. Endvidere skal man fremme et effektivt samarbejde mellem offentlige og private aktører, samt varetage et styrket samspil med internationale programmer i EU og andre lande.

Fødevareministeriet har udgivet en Strategi 2011-2013 og Handlingsplan 2011 for GUDP. ${ }^{86}$ Heri nævnes, at GUDP giver tilskud til projekter, der kan:

- Reducere natur-, miljø- og klimabelastningen

- Forbedre ressourceeffektiviteten

- Udvikle nye egenskaber hos dyr og planter

- Udnytte sidestrømme og restprodukter til/fra anden produktion

- Styrke indtjeningen på hjemme- og eksportmarkedet

- Forbedre fødevaresikkerheden og sundheden

- Bevare høj produktkvalitet gennem værdikæden

- Imødekomme nye forbrugertrends

- Øge anvendelsen af biobaserede produkter til nonfood formål

GUDP gennemfører ansøgningsrunder, som EUDP. GUDP prioriterer ansøgninger ud fra 8 kriterier, som vægtes ligeligt:

- Minimere næringsstofoverskuddet

- Begrænse klimapåvirkningen

- Reducere pesticidanvendelse

- Projektets provenu (for tilskudsmodtagere)

- Merværdien per rådevareenhed

- Videre økonomisk effekt (dvs. det videre økonomiske potentiale)

- Dyrevelfærd, fødevaresikkerhed, sundhed, arbejdsmiljø og etik

- Nytænkning, tværfaglighed og kommunikation

GUDP strategien sætter GUDP i relation til forskning og til en række andre synergiordninger, danske såvel som EU-baserede. GUDP har en bestyrelse, som beslutter om tilskud til projekterne.

I 2011 er der 200 mio. DKK til rådighed. De 170 mio. DKK anvendes på projekter, som har et budget på mellem 3-20 mio. DKK, mens resten af bevillingen går til mindre projekter mellem 0,5 mio. og 3 mio. DKK.

86 Fødevareministeriet: GUDP, strategi 2011-2013 og handlingsplan 2011, 27 sider, som overheads. Og bilag til Handlingsplan 2011: Faglig inspiration til ansøgere, 10 sider. 


\section{GUDP støttede projekter i 2010}

GUDP har fungeret siden begyndelsen af 2010 og har offentliggjort 2 lister med projekter støttet for i alt ca. 180 mio. DKK for året $2010{ }^{87}$ Listerne er meget summarisk ved kun at angive titel, projektholder og tilskudsbeløb. Det er dermed ikke muligt at vurdere, hvad der konkret er støttet og hvilke resultater, man måtte forvente.

En meget foreløbig vurdering, alene på baggrund af overskrifter, kunne være, at der ydes tilskud meget bredt til effektivitet, sundhed, miljø, nye markeder etc. og at miljø, klima, natur nok ikke er den parameter, som støttes mest. Følgelig må man tage til efterretning, at GUDP har et langt bredere sigte end mere snævert miljøeffektiv teknologisk. Derfor kan det virke forkert at bruge vinklen fra miljøeffektiv teknologi på GUDP. Hvis dette er tilfældet må man så samtidig fastholde, at der mangler flere midler til virkelig at få udviklet, gennemprøvet og demonstreret nye teknologier inden for området miljøeffektive landbrugsteknologier.

\section{Fødevareministeriets miljøteknologiordning}

Fødevareministeriet opretter i 2010 en Miljøteknologiordning i form af tilskud til projekter vedrørende investeringer i nye grønne processer og teknologier på primære jordbrugsbedrifter. Ordningen er en del af regeringens aftale om Grøn Vækst for perioden 2010-2015. Ordningen er en del af EU's landdistriktsprogram 2007-2013, idet en del af midlerne kommer fra EU-kommissionen. I 2010 har ordningen 145 mio. DKK, mens den i 2011 har 155 mio. DKK. Miljøteknologiordningen til de primære landbrugsbedrifter er direkte subsidier til en række områder. Her nævnes primært: reduktion af lugtgener, samt klimagasser og ammoniak, reduktion af pesticidanvendelsen, reduktion af tab i næringsstoffer i forbindelse med fodring og anvendelse af husdyrgødning. Ordningen er en automatisk ordning, hvor man kan få, hvis man opfylder vilkårene. Efter tur bliver ansøgninger behandlet, så man må sige, at der er tale om en klassisk subsidieordning. Man kan se detaljer om ordningen i en vejledning om tilskud, i en særlig oversigt over miljøteknologier på området, samt i EU-kommissionens forordning om støtte til udvikling i landdistrikterne. ${ }^{88}$

Generelt kan man sige, at der ikke synes at være de store perspektiver i denne traditionelle subsidieordning, som givetvis er etableret fordi EU-kommissionen betaler en betydelig del af tilskuddene. Det er vel meget almindeligt på landbrugsområdet, som har modtaget en meget betydelig del af EU-tilskud.

\footnotetext{
87 To summariske lister fra Fødevareministeriets hjemmeside.

88 Fødevareministeriet: Miljøteknologi 2011, Vejledning, 21 sider, og Aarhus Universitet: Oversigt over miljøteknologier i det primære jordbrug - driftsøkonomi og miljøeffektivitet, juni 2011, 60 sider, og EUkommissionens forordning nr. 1320/2006, 10 sider.
} 


\subsection{Erhvervsrelateret indsats for miljøeffektiv teknologi}

Under indtryk af det danske formandskab for forhandlinger om en ny klimaaftale til fortsættelse eller afløsning af Kyotoprotokollen, FN's COP 15, var der i Danmark i 2008 og især i 2009 en meget positiv dansk tilgang til en vision om en ny grøn vækstøkonomi i Danmark. I denne forbindelse fremlagde regeringen i oktober 2009 en Erhvervsklimastrategi, som skal fremme de markeds- og erhvervsmuligheder, som klimaforandringerne skaber. ${ }^{89}$

Regeringen nedsatte i september 2007 et Erhvervsklimapanel, der skulle rådgive regeringen om erhvervsrettede aktiviteter frem mod FN's klimakonference i København i december 2009. Erhvervsliv, vidensinstitutioner og organisationer deltog. Erhvervsklimapanelet var tæt inddraget i formuleringen af Erhvervsklimastrategien.

Erhvervsklimastrategien er mange positive ord og bløde formuleringer om partnerskaber og initiativer, som regeringen vil sætte i værk for at forbedre erhvervslivets muligheder for at fremme klimaløsninger. Med klimaløsninger menes ikke kun energiteknologi til udfasning af klimagasser, men også klimatilpasningsløsninger i form af teknologi og adfærd til at tilpasse sig klimaændringer.

De mest konkrete forslag er:

- 200 mio. DKK til særlige klimagarantier i Eksport Kredit Fonden

- Midlerne til EUDP, som nævnt ovenfor

- Nye initiativer på 600 mio. DKK i form af et tværgående program for markedsmodning og kommercialisering af nye grønne løsninger, som nævnt nedenfor, og i form af Green Lab DK - Danmark som grønt teknologilaboratorium, som nævnt ovenfor

Herudover blev der formuleret initiativer om:

- En kodeks for innovationsfremmende regulering

- Bedre hjælp til clean-tech iværksættere

- Forretningsdrevet klimaansvar

- Strategiske partnerskaber om klimaansvar

Disse initiativer er blødt formuleret, som hensigtserklæringer, og det er vanskeligt at følge deres implementering.

${ }^{89}$ Regeringen: Erhvervsklimastrategi, Globale udfordringer - danske muligheder, oktober 2009, 41 sider. 


\section{Fornyelsesfonden}

Som en opfølgning af Erhvervsklimastrategien blev der indgået en aftale mellem regeringen, Socialdemokratiet, Dansk Folkeparti og Det Radikale Venstre om detaljerne i den nye grønne fond, kaldet Fornyelsesfonden i november 2009. ${ }^{90}$ Herefter blev der fremsat et lovforslag i december 2009 om forslag til Lov om fond til grøn omstilling og erhvervsmæssig fornyelse. ${ }^{91}$ Og selve loven blev hurtig vedtaget med ikrafttrædelse den 4. februar $2010 .{ }^{92}$ Der bliver også udgivet en bekendtgørelse om Fornyelsesfonden, som beskriver en række detaljer i forbindelse med fonden og tilskudsgivningen. ${ }^{93}$

Formålet med Fornyelsesfonden er at støtte 3 hovedområder: grønne løsninger, velfærdsløsninger samt erhvervsmæssig omstilling. Under indsatsområderne grønne løsninger og velfærdsløsninger findes der to typer af aktiviteter, som kan støttes af fonden: innovation og markedsmodning. Fonden har dermed et bredere sigte, hvor grønne løsninger ca. er en tredjedel. Et særligt sigte er også erhvervsmæssig omstilling til tilskud til udkants Danmark, hvor man mangler arbejdspladser.

Der er afsat 760 mio. DKK for perioden 2010-2012. Fordelingen af midlerne på de forskellige områder forhandles politisk årligt. Det har dog vist sig, at det grønne områder leverer en meget stor andel af ansøgningerne, og følgelig vil det grønne område sikkert også få mere end sin tredjedel af midlerne.

Fornyelsesfonden administreres af et sekretariat i Erhvervs- og Byggestyrelsen. Fonden har en bestyrelse tilknyttet.

\section{Resultater}

I 2010 støttede Fornyelsesfonden grøn markedsmodning i 14 projekter med i alt 69,6 mio. DKK. 6 projekter var energiprojekter og 6 projekter var vandprojekter. 11 projekter fik tilskud, mens 3 af projekterne fik garantier.

Til grøn innovation blev der bevilget 51,3 mio. DKK til 11 projekter. Også her var størstedelen af projekterne indenfor områderne energi og vand.

Også støttede projekter om omstilling i områder, der er særligt hårdt ramte af finanskrise og globalisering var for flere projekters vedkommende grønne projekter. Det var bl.a. tale om et videns- og testcenter for grøn offshore energiteknologi, som fik 25 mio. DKK, mens et projekt om

\footnotetext{
${ }^{90} \mathrm{Aftale}$ mellem regeringen (Venstre og Det Konservative Folkeparti), Socialdemokratiet, Dansk Folkeparti og Det Radikale Venstre om: Fordelingen af globaliseringsreserven til innovation og iværksætteri mv. 20102012, 5. november 2009, 6 sider.

${ }^{91}$ Lovforslag L 92 om Lov om fond til grøn omstilling og erhvervsmæssig fornyelse, 16. december 2009.

92 Lov nr. 113 af den 1. februar 2010 om Lov om fond til grøn omstilling og erhvervsmæssig fornyelse.

93 Bekendtgørelse nr. 234 af 16. marts 2010 om støtte under fond til grøn omstilling og erhvervsmæssig fornyelse (Fornyelsesfonden).
} 
energirigtig renovering og et projekt om et algeinnovationscenter, hver modtog 5 mio. DKK.

Fonden er startet i 2010, og der er givetvis ikke gennemført evalueringer heraf. Der er udgivet en handlingsplan for 2011, som også indeholder beretningen fra bestyrelsen. ${ }^{94}$

\subsection{Transportrelateret indsats for miljøeffektiv teknologi}

På transportområdet blev der i januar 2009 indgået et bredt forlig om en grøn transportpolitik for perioden 2009-2020. ${ }^{95}$ Aftalen omfatter investeringer for i alt 94 mia. DKK, hvoraf de 57 mia. DKK skal bruges til kollektiv trafik, 26 mia. DKK på vejområdet og en restpulje på 11 mia. DKK, som ikke blev fordelt på aftaletidspunktet. Centralt i aftalen er grønne bilskatter og mere kollektiv transport.

De samme partier indgår i november 2010 en aftale om bedre mobilitet, som må siges at være en detaljeret udmøntning af den grønne transportaftale. ${ }^{96}$ Heri planlægges detaljeret de enkelte projekter.

I februar 2009 etablerer Transportministeriet et nyt Center for Grøn Transport. Centeret skal arbejde med en række konkrete initiativer, som kan reducere forureningen fra transport, primært CO2-udledningen. Centeret skal formidle resultaterne af forsøgsprojekterne ud til transportsektoren. Samarbejdet med erhvervslivet skal føre til en implementering af grøn transportteknologi.

Trafikstyrelsen arbejder også som en del af Centeret og arbejder bl.a. med el-biler og plug-in hybridbiler. Centeret har udarbejdet en redegørelse om el- og plug-in hybridbiler, som fortæller om køretekniske egenskaber, brugernes forventninger og behov samt de miljømæssige konsekvenser af udbredelsen af el- og plug-in hybridbiler. ${ }^{97}$

Trafikstyrelsen finansierer en række perspektivrige projekter. I begyndelsen af 2011 blev de første midler uddelt fra tilskudsordningen til 10 projekter med 42 mio. DKK i tilskud. Der er tale om tilskud til testning af elbiler, mindre brændstof til taxikørsel, hybridbusser etc. ${ }^{98}$

Dette betydelige arbejde for en grøn transportsektor har ganske store beløb knyttet til sig. Betydelige dele af politikken vedrører også traditionel udbygning af vejnet etc., men det må siges, at der ikke tidligere er blevet fokuseret så kraftigt på kollektiv trafik og miljøeffektive teknologier i

\footnotetext{
94 Fornyelsesfonden: Handlingsplan 2011, 12 sider.

95 En række partier: En grøn transportpolitik, 29. januar 2009, 30 sider.

96 En række partier: Bedre mobilitet, 26. november 2010, 22 sider.

${ }_{97}$ Center for Grøn Transport, Trafikstyrelsen: Redegørelse om elbiler og plug-in hybridbiler, april 2010, 65 sider

98 Se Trafikstyrelsens hjemmeside.
} 
transportsektoren i forhold til den mere traditionelle tilgang. Så alt i alt er det et skridt i den rigtige retning mod en grønnere transportpolitik.

\subsection{Forskellige politiske drøftelser i Danmark}

Der har flere gange de seneste år været intense drøftelser om grøn vækst og som en del heraf miljøeffektiv teknologi. Nedenfor nævnes nogle af disse debatter.

\section{Vækstforum}

I september 2009 nedsatte regeringen et dialogforum, Vækstforum, om mulighederne for fremme af vækst i Danmark med en række indflydelsesrige aktører i dansk erhvervsliv. Et møde om grøn vækst blev afholdt i februar 2010. Til brug for dette møde var der udarbejdet et oplæg om grøn vækst på 33 sider samt en række bilag hertil. Selve oplægget må betegnes som ganske visionært og et rimelig flot debatoplæg. Det beskriver udfordringer, muligheder og dilemmaer i den grønne omstillingsproces som grøn vækst også kaldes. Bilagene giver gode statusinformationer om grønne tilskud til erhvervsvirksomheder, analyser af cleantech branchen i Danmark, reguleringer på miljø og energi/klimaområderne etc. Hidtil var der ikke fra regeringens side udsendt så flot materiale om grøn vækst, men det skal også ses i sammenhæng med, at det er et meget spørgende debatoplæg og dermed på ingen måde forpligtende. ${ }^{99}$

Foreløbig kom regeringens vision om grøn vækst ikke længere, og man har fokuseret indsatsen på at forhandle en ny økonomisk genopretningsplan kaldet Reformpakken 2020. Denne reformpakke blev udgivet i april 2011 under titlen Reformpakken 2020 - kontant sikring af Danmarks velfærd. ${ }^{100}$ I denne gennemgang af Danmarks økonomiske udfordringer er der fokus på en genopretning af den økonomiske balancepolitik i Danmark eller mere konkret på besparelser. I medierne har drøftelserne om afskaffelsen eller begrænsningen af efterlønnen fremstået som helt centrale, mens forslag om direkte fremme af vækst ikke har nogen egentlig plads. Væksten skal komme ved justeringen af økonomiske parametre som f.eks. offentlige udgifter etc.

Umiddelbart efter at regeringen plus Dansk Folkeparti og Det Radikale Venstre indgår forlig om Reformpakken medio maj udsender Socialdemokratiet og SF sin reformpakke med en betydelig større vægt på støtte til

\footnotetext{
${ }^{99}$ Regeringen: Grøn Vækst: udfordringer, muligheder og dilemmaer i den grønne omstilling, februar 2010, 35 sider, samt 5 bilag om temaer om grøn vækst.

100 Regeringen: Reformpakken 2020 - Kontant sikring af Danmarks velfærd, april 2011, 334 sider.
} 
direkte vækst. ${ }^{101}$ I modsætning til regeringen satser hoveddelen af oppositionen ikke på en udpræget besparelsesstrategi for væksten, men snarere en kombination af direkte hjælp til væksten og besparelser.

En stærk inspiration til den mere vækstaktive del af oppositionens udspil har SF's udspil om „Ny vækst - Nye job“ været. ${ }^{102}$ Her foreslås en kraftig satsning på en række områder som klima-, energi- og miljøteknologi, samt velfærds- og sundhedsteknologi. Det skønnes, at der kan skabes 75.000 nye private arbejdspladser over de kommende 10 år. Regeringen har angrebet denne plan for at være „pick the winners“, altså støtte og tilskud til allerede stærke områder og virksomheder på enkelte udvalgte felter. Dette afvises af SF, der fremhæver, at der er tale om at vælge strategiske vigtige vækstområder globalt set sammenkoblet med, hvad Danmark er rimelig god til.

En anden debat skal også nævnes: nemlig debatten om tilskudsmidler på energiområdet. Det Miljøøkonomiske Råd, som i Danmark er en del af det Økonomiske Råd har udgivet en årsrapport i 2011, hvor energi- og miljøforskning har sit eget afsnit. ${ }^{103}$ Heri argumenteres for, at det er i orden med forskningsstøtte, mens støtte til demonstrationsprojekter etc. kaldes erhvervsstøtte. Denne form for erhvervsstøtte mener Det Miljøøkonomiske Råd er overflødig. Argumenterne er blevet modgået af formanden for Klimakommissionen Kathrine Richardson i en artikel i Politiken, hvor hun argumenterer for, at denne form for støtte er til for at fremme klimapolitikken. Den er ligeledes blevet kritiseret for helt at overse væsentlige fordele som f.eks. patentering af nye energiopfindelser. ${ }^{104}$ Man kan måske nok sige, at det er vanskeligt at kritisere Det Miljøøkonomiske Råd for en dårlig faglig analyse. Det må dog fastholdes, at denne analyse ikke kan rumme den dimension, der udtrykker sig i værdien af at etablere demonstrationsaktiviteter med offentlige midler. En lang række af sådanne demonstrationsprojekter kan ikke blive realiserede uden offentlige midler.

\section{Øvrige danske initiativer}

I en vurdering af hvad Danmark har gjort inden for grøn vækst bør man se på den række af handlinger, som er blevet taget de sidste 10-20 år. Danmark er f.eks. ét af de lande i verden, som bruger grønne afgifter mest aktivt med et provenu på ca. 70 mia. DKK om året svarende til ca. $10 \%$ af indtægter ved beskatning. Andre forhold kan nævnes, men der er ikke nok plads i denne skrivning.

\footnotetext{
101 Socialdemokratiet og SF: Fair Løsning 2020 - sammen om Danmark, 94 sider, 16. maj 2011.

102 SF: Ny Vækst - Nye Job, 75.000 nye private arbejdspladser, april 2010, 36 sider.

103 De Økonomiske Råd: Diskussionsoplæg: Trafikstøj, Energi- og miljøforskning, og Afgifter og klimamål. 23. februar 2011, 300 sider, samt en kronik i Politiken af formandskabet for Det Miljøøkonomiske Råd: Vindblæst. Erhvervsstøtte redder ikke klima, den 3. april 2011.

104 Frans Clemmensen, cheføkonom, Dansk Energi, indlæg i Politiken den 6. april 2011.
} 
Regeringen nævner flere forhold i sit/vækstforums notat om grøn vækst, som „de første skridt mod en grøn omstilling - større initiativer“: 1) energiaftalen fra 2008, 2) aftalen om grøn transportpolitik fra 2009, 3) Forårspakken 2.0. især om skatteforhold fra 2009, 4) erhvervsklimastrategien fra 2009. Grøn vækst/landbrugsaftalen nævnes også. Den er omtalt ovenfor. Man må afvente resultaterne fra de enkelte indsatser for at vurdere, hvor effektive elementer de er i en ægte strategi for grøn vækst. Der kommer også løbende enkeltinitiativer, som f.eks. det nye lovforslag om Green Labs program, dvs. grønt vækstlaboratorium til at afprøve nye perspektivrige teknologier.

Et initiativ fra den private sektor fortjener at blive nævnt: Mandag Morgen har sammen med Københavns Kommune, Dong og Realdania med udgangen af september 2010 etableret Green Growth Economies, som et dansk drevet internationalt initiativ. Deltagerne er lande, regioner og byer, som gør en særlig indsats for grøn vækst. Det bliver spændende at følge dette initiativ fremover.

\subsection{Danske eksempler med international succes}

Det tydeligste eksempel på en dansk international succes er den danske vindmølleindustri, som står for en eksport på 46 mia. DKK, ifølge vindmølleindustrien selv. Der er ganske mange virksomheder i vindmølleindustrien, om end Vestas, Simens Wind Power og LM Glasfiber skiller sig ud fra en større gruppe, som også indeholder mange underleverandører i vindmølleindustrien. Successen er internationalt kendt og udviklet i Danmark igennem 30 år, hvor man fra statens side støttede vindmølleopstillinger på økonomisk gunstig måde, standardiserede vindmøllerne, oprettede testcenter, etc. Der er ingen grund til at skrive mere om dette eksempel.

På Miljøstyrelsens hjemmeside ecoinnovation.dk er der omtalt en række eksempler på succeshistorier, hvoraf man kan hente inspiration. Et eksempel er verdens største virksomhed for genanvendelse af bildæk, som kun har eksisteret i 20 år, Genan. Denne virksomhed har udviklet sin egen fuldautomatiske teknik til at genanvende gamle bildæk. Bildækkene neddeles, og man laver et ensartet produkt af høj kvalitet af gummepulver og gummigranulat, der samtidig begrænser ressourcer og omkostninger. Genan har etableret sig meget stærkt i Tyskland og kan her behandle $30 \%$ af de brugte bildæk. Genan planlægger at etablere 15 anlæg i USA og har en vision om at behandle $10 \%$ af verdensmarkedet.

Danisco har udviklet en vegetabilsk baseret erstatning for ftalater, som har de samme blødgørende egenskaber som den gruppe af kemiske stoffer som kaldes ftalater, men uden risiko for hormonforstyrrende effekter på mennesker. Især i legetøj, mademballage og medicinsk udstyr kan dette nye produkt kaldet, Grindsted Soft-N-Safe bruges som erstatning til de hidtidige så problematiske kemiske blødgørere. 
En virksomhed NoNOx har udviklet en teknologi, som kan reducere de giftige kvælstofoxider (NOX) i dieselmotorers udstødning med mindst $90 \%$ Med NoNOx-teknologien omdannes kvælstofoxiderne i dieseludstødningen til uskadelig kvælstof og vanddamp og er allerede installeret på 50.000 lastbiler i Europa.

Man kan også nævne teknologier til reduktion af kvælstofoxider fra skibe. Den ene teknologi er en ny brændstofventil og en ny dyse til eksisterende skibsmotorer, der i løbet af få år vil blive installeret på 800 ældre skibe. Dette vil medføre en reduktion på 60.000 NOx fra skibene pr. år. En anden teknologi består af tilsætning af vand til marin gasolie og kan ved hjælp af en emulgator resultere i reduktion af NOx under forbrændingen på op til $60 \%$

Et utraditionelt projekt fra byen Kalundborg kaldes industriel symbiose, fordi 7 virksomheder bruger hinandens restprodukter som råstoffer. Projektet har opnået store miljøresultater og er kendt internationalt, fordi mange andre lande har lignende store klynger af virksomheder, der kan genbruge hinandens restprodukter.

I Oxford Researchs evaluering af EUDP-programmet nævnes 10 eksempler på virksomheder, som har udviklet spændende teknologier. Disse virksomheder oplistes:

- Terranol, som har udviklet en ny gærstamme til en mere effektiv produktion af 2. generations bioethanol

- Dall Energy har udviklet et banebrydende multibrændselsanlæg, som står overfor markedsføring

- GMR maskiner, Serenergy og Teknologisk Institut har udviklet brændselsceller til længere rækkevidde i elektriske køretøjer

- Firmaet H2 Logic har udviklet brint- og brændselsceller i verdensklasse til brug i by-, service-, fritids- og intern transport køretøjer

- Wave Star har udviklet en ny bølgekraftmaskine

- En gruppe af virksomheder har udviklet termisk lagring i betonkonstruktioner til at lagre energi

- En ny virksomhed, Inventilate A/S har sammen med Teknologisk Institut udviklet en meget ressourcebesparende ventilationsenhed, som giver store miljøfordele

- En række virksomheder med Teknologisk Institut i spidsen har udviklet et koncept, kaldet Albertslundkonceptet, til energirenovering af boliger

- En række vindmøllevirksomheder har udviklet nye testmetoder for at forbedre vingerne på møllerne

- Mekoprint og flere forskningsinstitutter har udviklet plastsolceller, som kan bruges meget bredere end hidtil 
Publikationen fra Brøndum \& Fliess om Cleantech (2011) nævnt tidligere i teksten har også 7 eksempler på virksomheder, som har udviklet nye teknologier og er i rivende udvikling.

\subsection{Arbejdet med efterspørgsel i Danmark}

I forhold til efterspørgselsdimensionen kommer den givetvis mest markant frem i forhold til de situationer, hvor der er et meget direkte pres fra det politiske system i form af krav, der skal opfyldes, f.eks. på klimaområdet, hvor man skal opfylde en procentdel vedvarende energi eller reduktion af klimagasser. I sådanne situationer arbejder de regulerende myndigheder meget målrettet på at lave regler, som får den nødvendige effekt. I klimapolitikken vil dette givetvis blive øget i fremtiden.

Internationale krav som f.eks. på skibsområdet er et eksempel på, hvordan sådanne regler motiverer til teknologiudvikling. På skibsområdet synes dette at have været ganske simple løsninger.

Som hovedregel er der dog ikke nogen meget direkte kobling til efterspørgselssiden i forbindelse med tilskudsgivning til enkelte projekter. Dette tænkes yderst sjældent ind. Som regel er der en overordnet tilgang i form af overordnede politiske ønsker til at reducere et miljøproblem, men yderst sjældent en direkte kobling til en bestemt teknologi.

Et område må dog siges at skille sig ud, og det er offentlige grønne indkøb. Her vil der blive satset mere i fremtiden, i og med at der er oprettet et offentligt partnerskab på området.

Man har i Danmark igennem længere tid drøftet, hvordan man kunne $\emptyset$ ge offentlige grønne indkøb. Initiativer bremses af, at indsatsen ikke må koste det offentlige flere midler, i og med at der så skal afsættes særlige midler hertil. Årsagen er det såkaldte DUT-princip (Det Udvidede Totalbalanceprincip), hvorefter der skal betales kompensation til kommuner og regioner, hvis staten beslutter at gøre offentlige grønne indkøb bindende. Derfor er den eneste vej i Danmark en frivillig vej hos de offentlige indkøbere.

En interessant rapport fra Miljøstyrelsen har vurderet de miljømæssige konsekvenser ved øgede offentlige grønne indkøb. ${ }^{105}$ Rapporten virker som en meget solid dokumentation af de miljømæssige og økonomiske konsekvenser af at øge indkøbene. Rapporten viser, at man kun kan opnå relativt små miljøresultater. Det er sjældent, at man ser sådanne rapporter om miljøeffekten af øgede grønne indkøb. Normalt nævnes blot det årlige beløb på offentlige indkøb, sjældent gås der i dybden med miljøresultaterne.

105 Miljøstyrelsen: Miljømæssige og økonomiske konsekvenser af øgede offentlige grønne indkøb, udført af Cowi A/S, Miljøprojekt nr. 1218 2008, 94 sider. 


\subsection{Konklusion på Danmarks aktiviteter}

Der har været flere analyser af antallet af virksomheder i den danske miljøeffektive teknologisektor. Vurderingerne af antallet går fra 420 til 1.200 virksomheder, endda hvor det samme firma har analyseret to gange. Det bedste bud må være i størrelsesordenen 500-600 virksomheder. Det ville dog være perspektivrigt, hvis der blev skabt en større konsensus om, hvor mange virksomheder der er i Danmark. Det ville også være interessant, hvis man foretog en opdeling mellem miljø og energi, og henholdsvis Miljøstyrelsen og Energistyrelsen stod for listeføringen, som bør være offentlig tilgængelig, så man ikke hele tiden møder nye rapporter med nye tal.

Eksporten fra sektoren kan i 2010 noget usikkert sættes til 85 mia. DKK. Det er 55 mia. DKK for energisektoren, idet rådgivning lægges til tallene fra Energistyrelsen og DI. Og måske - men meget usikkert - et tal på ca. 30 mia. DKK til miljøområdet. De 43 mia. DKK på opgørelsen af eksport er ikke dokumenteret ordentligt på nogen måde. Det er fornuftigt at arbejde med en opdeling af energi og miljø på eksportområdet og samtidig sikre, at der ikke er et overlap. Energidelen har stort set fundet sin form, mens der mangler en mere sikker tilgang på miljøområdet.

Den mest spændende satsning i Danmark er på klima- og energiområdet, hvor bevillingerne stiger fra 2004 og frem til 2010-11 til en samlet sum af 1,1 mia. DKK hvert år i 2010 og 2011. Der er ganske vist ikke mindre end 7 forskellige tilskudsordninger, men en stadig stigende koncentration om EUDP, som den vigtigste ordning. Den samlede forskning, udviklings- og demonstrationsindsats afrapporteres også årligt i publikationen Energi med det pågældende årstal efter, f.eks. Energi 11, hvor de 2 sidste års rapporter er ganske inspirerende læsning og gode oversigter over, hvad der foregår på området. EUDP programmet er i september 2011 blevet effektevalueret uafhængigt med flotte resultater.

Man må sige, at EUDP udvikler sig stadig mere perspektivrigt. Programmet administreres af Energistyrelsen og kobles i stigende grad til den klimapolitiske opgave, som Danmark påtager sig om kun at bruge vedvarende energi. Denne kobling bør naturligvis sættes i bedre system og vægten bør i stigende grad lægges på de teknologier, som man allerede nu kan se, der bliver brug for. Man kan også forbedre indsatsen ved at få udarbejdet bedre strategier fuldt opdaterede på samtlige teknologiområder, samt analyser af de enkelte virksomhedsområder i form af vilkår etc. for virksomhederne. Efterspørgselssiden på energiområdet skal trimmes, så det bliver en bedre forretning at producere og sælge teknologier, som der er et hjemmemarked til. Mange af de regler og ordninger, som skal fremme vedvarende energi eller energieffektivitet er endnu ikke helt på plads.

Selve miljøområdet i traditionel forstand og i Miljøstyrelsens regi satser på vand, luft og affald. Programmet synes at have tabt noget af luften i forhold til de første år i 2007-08. Der er færre midler og man må forsø- 
ge at genskabe et mere sikkert fundament under indsatsen i form af analyser af de enkelte områder som vand, luft og affald mv. Tilskudsmidlerne bliver givet til for små projekter, fordi midlerne er for små. Dermed bliver perspektiverne også nogle gange vanskelige at få øje på. Der er med en ny regering annonceret, at miljøteknologi tilføres 50 mio. DKK i 2012, så der i alt er 77 mio. DKK til rådighed i dette år. Der er skal også oprettes et Miljøteknologisk Udviklings- og Demonstrationsprogram (MUDP) efter inspiration fra EUDP på energiområdet. Der er endnu ikke sket en evaluering af aktiviteterne, men det kommer forhåbentligt snart. Miljøstyrelsens hjemmeside eco-innovation.dk er ganske udmærket og giver mange gode informationer.

Af successer, som miljøprogrammet allerede har opnået kan man nævne de meget perspektivrige partnerskaber, som i flere tilfælde skaber helt nye synergier mellem virksomhederne. Især partnerskabet for renere skibsfart er blevet en stor og egentlig uventet succes, ikke mindst fordi der er international regulering i vente, og Danmark har en stor transportflåde. Efterspørgselssiden gøres der ikke noget for ud over den almindelige tilgang med regulering, når der er behov og politisk mulighed.

Programmet på landbrugsområdet, GUDP og det erhvervsrelaterede program, Fornyelsesfonden er først kommet rigtig i gang i 2010 og har ikke nået at vise megen information på tilskudsområdet. Disse to programmer bør gøre mere ud af informationssiden om aktiviteterne og fortælle om aktiviteter og resultater. Selvfølgelig bør man også evaluere programmerne efter nogle få år. Der er ikke rigtig nogen efterspørgselskobling forbundet til de to programmer, måske lidt til landbrugsområdet. Reguleringen henhører under Miljøministeriet, og det er herfra man skal bruge resultaterne i et bredere perspektiv. De to programmer bør derfor kobles ind i en større sammenhæng relateret til efterspørgselssiden.

Der mangler også i Danmark en bedre samling og koordinering af de forskellige aktiviteter til gavn for alle aktørerne. Som det ser ud nu, kører klima- og energiområdet foran meget selvstændigt, mens de øvrige miljøområder med flere ministeriers aktiviteter mangler at finde bedre sammen. Skal Danmark fremover indfri løfterne til miljøeffektiv teknologi, miljøteknologi og grøn vækst skal der samlet set en bedre satsning i form af årsværk, tilskud, efterspørgselsfokus, eksporthjælp etc. for at virkeliggøre denne vision, som har udviklet sig i Danmark.

Endelig bør man påpege, at man fra politisk side bør sikre en mere stabil situation for bevillinger, end den der reelt har virket de sidste års tid. Uden rimelig stabil og forudseelig bevillingssituation og politisk opbakning til indsatsen ud over flotte festtaler, får man ikke tilstrækkelig succes. 


\section{Finlands indsats for miljøteknologi 2004-2011}

I Finland anvendes i engelsk tekst for det meste begrebet cleantech virksomheder eller environmental technology. Det vil være mest hensigtsmæssigt at bruge ordet miljøteknologi, som det begreb, der bliver anvendt i Finland. Man bruger i øvrigt også hyppigt eco-innovation eller miljøinnovation, som dog ikke helt synes at udkonkurrere begrebet miljøteknologi. Derfor bruges i dette afsnit om Finland begrebet miljøteknologi.

\subsection{Finsk erhvervslivs aktiviteter inden for miljøteknologi}

Det virkelige omfang af den finske sektor for miljøteknologi vurderes i Finland til ikke at kunne defineres på samme måde som traditionelle industrielle sektorer, primært fordi miljøteknologiske virksomheder gennemtrænger hele samfundet. Cleantech firmaer producerer produkter og serviceydelser, som har færre negative effekter på miljøet end deres alternativer.

I Finland blev det i 2007 vurderet, at den årlige samlede omsætning for miljøteknologi sektoren var på 4,5 mia. Euros for året 2007. I 2010 nævner den finske minister for beskæftigelse og økonomi omsætningen til at være 12-17 mia. EUR, som er et stort interval, men afhængig af den måde man opgør sektoren på. ${ }^{106}$

Miljøstatistik viser, at der var næsten 300 virksomheder i Finland i 2005 , som beskæftigede sig intensivt med miljøteknologi. De $25 \%$ største virksomheder stod for $80 \%$ af omsætningen i 2005/06. ${ }^{107}$ Andre meldinger kunne tyde på, at der nok er flere virksomheder, f.eks. ca. 400 virksomheder eller noget mere, idet det blev oplyst, at det finske cleantech erhvervsliv deltog med 240 virksomheder i The Cleantech Cluster, og dette tal var skønnet til at være $60 \%$ af cleantech virksomheder i Finland. ${ }^{108}$

\footnotetext{
106 Eco-innovation Observatory: EIO country brief 2010: Finland, 17 sider, side 5.

107 Turku School of Economics and Bu siness Administration/Päivi Keskitalo: Internationalisation of Finnish Environmental Technology to Poland, 2006, 53 sider.

108 Tekes: Towards green growth? - The position of Finland in environmental technology, april 2011, 61 sider, side 30 .
} 
Et andet meget større tal på cleantech virksomheder i Finland er opgjort af Clean Tech Finland til ca. 2.000 virksomheder. ${ }^{109}$ De 100 største virksomheder er for $95 \%$ ansvarlig for en omsætning på ca. 18 mia. EUR i 2010. Sektoren vurderes til at beskæftige 30.000 ansatte. ${ }^{110}$ Denne opgørelse er lavet af en interesseorganisation, og materialet til at dokumentere opgørelsen må siges ikke at være særlig overbevisende.

På denne baggrund er det meget vanskeligt at konkludere, hvor mange virksomheder der er i Finland indenfor miljøteknologi. Der kan være ca. 400 virksomheder i Finland, som kan kaldes miljøteknologivirksomheder, men der kan også meget vel være et betydeligt større tal, som Clean Tech Finland angiver.

\subsubsection{Eksport af finsk miljøteknologi}

Den finske miljøsektor blev i 2006 vurderet til at have en eksportandel på $50 \%$ af sin omsætning. Dette giver en størrelsesorden på 2,25 mia. EUR. ${ }^{111} 90 \%$ af eksporten gennemføres af de største 20-30 virksomheder, mens et større antal små virksomheder ikke står for megen eksport. De vurderes dog til at have et stort potentiale. ${ }^{112}$ De største markeder for eksporten er USA og Japan, samt de gamle EU-lande med samlet lidt over halvdelen af eksporten. Hertil er der også en ikke ubetydelig eksport til de nye EU-lande, Rusland og andre tidligere sovjetiske stater etc. Dette er givetvis relativt forældede tal.

Clean Tech Finland nævner i sit interne notat, at $75 \%$ af omsætningen eksporteres, hvilket giver 13,5 mia. EUR, hvis omsætningen er 18 mia., som nævnt ovenfor. Dette tal er ganske meget større end det tidligere nævnte. Clean Tech Finland nævner de vigtigste markeder i Europa til at være: Tyskland, Sverige og hjemmemarkedet, mens Kina, Indien og Rusland nævnes som de vigtigste markeder udenfor Europa. Denne vurdering afviger ganske meget fra den tidligere vurdering.

Det er meget vanskeligt at sige noget endeligt om eksportens størrelse fra miljøsektoren i Finland. Man kan faktisk kun konkludere, at det bør undersøges nærmere for at få et mere sikkert billede af, hvor meget Finland eksporterer på området. En statslig myndighed bør også kobles på en sådan talopgørelse, så det ikke kun er sektoren selv, der opgør sine egne tal.

\footnotetext{
109 Clean Tech Finland: internt notat, november 2011, 2 sider.

110 Clean Tech Finland: internt notat, november 2011, 2 sider.

111 Ministry of Trade and Industry: Finlands national RoadMap for the implementation of the Environmental Technologies Action Plan for the European Union (ETAP), januar 2006, 33 sider, s. 12.

112 Indlæg af Jukka Noponen: Finnish Cleantech market development, 5-6 juni 2006, Cleantech Forum Lahti, 8 sider.
} 


\subsection{Vurderinger og initiativer for miljøteknologi i Finland}

Dette afsnit forsøger, efter en kort introduktion af centrale aktører, at give et overblik over, hvad der er sket i Finland vedr. miljøteknologi i perioden. Dermed er der tale om en kronologisk gennemgang af aktiviteter baseret på tilgængelige rapporter. Det kan måske indvendes, at dette kun har en historisk interesse og er mindre relevant $i$ en forståelse af området i dagens Finland. Omvendt må man dog fremhæve, at 7 år faktisk er ganske få år i et udviklingsperspektiv, og at det er meget vanskeligt at forstå situationen i dagens Finland uden dette tilbageblik.

\section{Centrale aktører i Finland på statsligt plan}

Hovedaktørerne blandt de finske ministerier er Miljøministeriet og Ministeriet for beskæftigelse og økonomi (MEE, der frem til den 1. december 2007 var Ministeriet for handel og industri). Disse to ministerier samarbejder på en række overlappende områder gennem forskellige kommitéer, paneler og andre typer af fora. Miljøministeriet er naturligvis primært involveret i den reguleringsmæssige side af sagen, f.eks. ved at udvikle retningslinier for energieffektivitet, og fastsætte regler på miljøområdet. MEE har den specifikke rolle at skulle promovere miljøteknologi, inklusiv vedvarende energi. Årsagen til tildelingen af denne rolle er, at MEE formulerer innovationspolitikken i Finland.

\section{Tekes}

Tekes, den finske finansieringsstyrelse for teknologi og innovation, er den vigtigste offentlige organisation for forskning og udvikling i Finland. Tekes giver tilskud til industrielle projekter og forskningsprojekter og fremmer især innovative, risiko-intensive projekter. Tekes tilbyder internationale partnere en adgang til aktører for vigtig teknologi i Finland. Tekes havde i 2006 et budget på 400 mio. EUR til at finansiere ca. 2000 projekter årligt. ${ }^{113}$ I 2011 har Tekes et budget på ca. 600 mio. EUR, hvoraf der finansieres projekter til cleantech forskning og udvikling. Man kan f.eks. nævne områder som BioRefine, Build Environment, Fuell Cell og vandprogrammer mv. Tekes er langt den største tilskudsyder til miljøteknologi i Finland. ${ }^{114}$

Tekes bruger programmer til at allokere finansiering, networksarbejde og eksperttjenester til områder, som er vigtige for erhvervslivet og samfundet. Programmerne følger Tekes' overordnede strategi og har bidraget til at udvikle finsk innovation i mere end 20 år.

\footnotetext{
113 Ministry of Trade and Industry: Finnish national RoadMap for the implementation of the Environmental Technologies Action Plan for the European Union (ETAP), januar 2006, 33 sider, s. 3. 114 Undersøgt af Gaia Consulting Oy som hjælp til dette projekt.
} 


\section{Finlands tekniske forskningscenter, VTT}

VTT er Finlands vigtigste offentlige forskningsinstitution og en vigtig partner i miljøteknologiske programmer og projekter. VTT er et af Europas største forsknings- og udviklingscentre, bl.a. arbejder man med forskellige fremskrivningsstudier. Man kan f.eks. nævne klima- og energiteknologi, som et særligt vigtigt område.

\section{Sitra}

Sitra, den Finske innovations Fond, viste sig tidligt som hovedaktør i det finske arbejde for at fremme miljøteknologi. Sitra er en uafhængig offentlig institution, som fremmer udvikling i Finland i tilknytning til det finske parlament. Sitra kan uafhængigt tage temaer op og foretage vurderinger heraf. Temaerne eller programmerne kan være studier, strategiprocesser, innovative eksperimenter, erhvervsudvikling eller finansiering i firmaer. Sitras aktiviteter finansieres af de bevillinger eller den kapital, som Sitra råder over. Hovedaktiviteten er kapitalinvesteringer i erhvervslivets aktiviteter og derefter en aktiv anvendelse af overskuddet til at fremme Sitras formål.

\section{Finlands Akademi}

Finlands Akademi finansierer en del forskningsprojekter indenfor området for miljøteknologi. Samlet anvender Finlands Akademi årligt ca. 340 mio. EUR, som er $16 \%$ af regeringens F\&U midler. Ganske meget af denne forskning går til kllima/energi og miljø.

\section{SYKE, det finske miljøinstitut}

SYKE er både et forskningsinstitut og et center for ekspertise. SYKE gennemfører en række forskellige miljøanalyser, bl.a. analyser af politik, teknologiske forandringer, produktion og forbrug etc. Man kan nævne, at SYKE har gennemført et projekt om forøget eco-efficiency, som var en del af forskningsprogrammet for avanceret teknologipolitik (proACT). ${ }^{115}$

\section{Finpro}

Finpro har ansvaret for at fremme internationalisering af Finlands virksomheder og for at reducere den risiko, som er forbundet med denne internationalisering. Finpro er naturligvis fokuseret på eksport fra Finland og har mere end 300 eksperter og 50 centre i 40 lande.

\section{OSKE Og SHOK}

Man bør også nævne OSKE (Centeret for ekspertprogrammer), som er en klynge baseret model, der for tiden har 13 ekspertklynger og 21 regiona-

115 SYKE: Increasing eco-efficiency - an analysis of the factors generating innovations (Ecoinno), se SYKEs hjemmeside på Miljøministeriets hjemmeside. 
le ekspertcentre. OSKE arbejder med regionale ressourcer og aktiviteter. En af de nationale klynger er Cleantech klyngen. Og man bør nævne SHOK (De strategiske centre for Videnskab, Teknologi og Innovation), hvor forskere fra universiteter mv. samarbejder med virksomheder i at få nye produkter fremmet.

\section{Finlands National Roadmap for the implementation of the environ- mental technologies action plan for The European Union (ETAP)}

Finland afleverede i begyndelsen af 2006 en national roadmap til ETAP, som et forsøg på at sammenskrive, hvad der var status og visioner for miljøteknologi i Finland for området. ${ }^{116}$

Som for flere andre lande etablerede denne roadmap også et overblik over Finlands aktiviteter på området for miljøteknologi, som ikke havde været tilgængelig tidligere.

Finlands roadmap definerede de nationale målsætninger og beskrev udfordringer. Rapporten gennemgik en række aktiviteter, som var ved at blive gennemført eller allerede gennemført, samt aktiviteter, som var planlagte. Og rapporten beskriver Finland's nationale innovationssystem rimeligt detaljeret med beskrivelse af, hvem der var aktive, og hvad de brugte af økonomiske midler, f.eks. tilskud. Det var indlysende, at det nationale innovationssystem i Finland skulle beskrives, ikke mindst fordi det ofte vurderes som måske det bedste i verden. Hertil omtaler rapporten en række eksempler på miljøteknologiprojekter i Finland. Roadmappen for Finland var fremadskuende for området med beskrivelse af en række opgaver, som den finske stat eller andre aktører skal udføre fremover. Der blev også nævnt en del anbefalinger, som der dog ikke var klar adresse på, hvem der skulle udføre.

Rapporten beskæftigede sig også med verifikation af teknologier, sådan som ETAP også selv gjorde det. Og rapporten omtalte også flere netværk i industrien, bl.a. et stærk erhvervsorienteret netværk i Lahti regionen, hvor Lahti Videnskabs- og Erhvervspark Ltd. koordinerer et netværk af miljøfokuserede videnskabsparker.

Endelig bør man nævne, at der var et særskilt afsnit om affald og affaldsstrategi, samt et afsnit om energiteknologi. Her blev det bl.a. nævnt, at energisektoren har fået 33 mio. EUR i tilskud hvert år i en årrække. ${ }^{117}$ Og der blev også fokuseret på styrken i at anvende offentlige udbud i forsøg på at fremme miljøteknologi.

\footnotetext{
116 Ministry of Trade and Industry (senere Ministeriet for beskæftigelse og økonomi): Finnish National Roadmap for the implementation of the environmental technologies action plan for the European Union (ETAP), december 2005, 33 sider.

117 Finlands RoadMap side 23.
} 


\subsubsection{Sitras Miljøprogram 2004-07, Environmental Programme}

I 2004 påbegyndte Sitra en proces, hvor man ville starte et program i 2005 til gennemførelse over 3 år med udløb i 2007. Formålet med programmet var at fremme miljøteknologi erhvervslivet i Finland, især grupperinger af små og mellemstore firmaer. Man ønskede at styrke disse grupperinger inden for miljøteknologi og give finansiel støtte til demonstrationsaktiviteter eller prototyper, så interessante innovationer i demonstration kunne videreformidles til forskellige aktører. ${ }^{118}$ Man inddrager også TEKES, den finske styrelse til finansiering af teknologi og innovation, og VTT, som er det tekniske forskningscenter i Finland, som partnere i programmet.

Der var 3 fokusområder i programmet:

- Kapitalinvesteringer til virksomheder under udvikling

- Udvikling af internationaliserings netværk

- National udvikling og handlingsplan

Programmet blev gennemført for et totalt budget på 6 mio. EUR.

Kernen i programmet var at forsøge at fremme miljøerhvervslivet i Finland og herefter forsøge at etablere en større satsning på området for fremme af miljøeffektiv teknologi.

Som noget af det sidste i Sitras arbejde i miljøprogrammet anbefaledes, at der skulle etableres et fælles Clean Tech Finland Business Forum bestående af virksomheder for at fremme udviklingen og internationaliseringen af det finske erhvervsliv i miljøteknologi.

Som en statslig beslutning om en vision for miljøteknologi eller ecoinnovasion bør man nævne teksten i Den Nationale Handlingsplan for bæredygtig forbrug og produktion fra juni 2005. Den har følgende tekst, som her nævnes på engelsk: ${ }^{119}$

„Finland is among the leading countries in terms of environmental technologies and innovative eco-efficient services. Conditions are favourable for the development, adoption and exporting of innovations. Socioeconomic controls and incentives are better developed and permanently support innovation, eco-efficient technologies and sustainable consumption patterns."

\footnotetext{
118 European Commission Environment's hjemmeside: case 8: Sitra environmental programme, Finland, 7 sider. Og indlæg af direktøren for Sitra, Jukka Noponen: Sitra's Environmental Programme - Cleantech Finland, den 15-16 November 2005, Skt. Petersburg, 3 sider.

119 Finlands Roadmap, side 18.
} 
Efterfølgende vurderinger af programmet viser, at noget af det vigtigste der skete i kraft af programmet var, at de fleste aktører i Finland blev bragt sammen. ${ }^{120}$

\subsubsection{Den nationale handlingsplan til udvikling af miljøteknologi}

Den Finske innovations Fond, Sitra, gennemførte en række seminarer eller workshops i efteråret 2006 om miljøteknologi. Man besøgte Nederlandene, Danmark og Japan. I januar 2007 udgav Sitra en national handlingsplan til udvikling af miljøeffektiv teknologi kaldet Clean Tech Finland - improving the environment through business. ${ }^{121}$ Planen blev udarbejdet sammen med erhvervssektoren, relaterede organisationer etc., dvs. alle de vigtigste aktører i Finland.

Sitras motiv til at lave en handlingsplan er, at man vurderer, at der er et stort behov for, at Finland kan blive bedre til at fremme miljøteknologi, især eksportdelen heraf. Finland har et stærkt miljøimage og vurderes i internationale sammenligninger som et af de bedste miljølande $\mathrm{i}$ verden. Det finske miljøteknologierhvervsliv omsætter for 4,5 mia. EUR om året. Den vigtigste del af sektoren er nogle få meget store virksomheder, som arbejder internationalt. Der er dog mange små og mellemstore virksomheder i miljøerhvervssektoren. Disse virksomheder har et stort uudnyttet potentiale, især hvis de bliver bedre til at samarbejde.

I handlingsplanen opstiller man målet med en vækst på $15 \%$ åligt for sektoren og en fordobling af samlede omsætning til 10 mia. EUR i 2012.

Handlingsplanens vision er, at Finland skal være et ledende cleantech land i 2012. For at opnå denne vision foreslår planen, at der iværksættes 4 strategiske projekter i perioden 2007-2012:

- Finland - det mest kendte cleantech land i verden. Miljøekspertise skal være en nøgle faktor bag finske produkters eksport

- Finland som en optimal platform for vækst i den sektor, som arbejder med miljøeffektiv teknolog. Udbud, finansiering og tilskudssystemet skal geares, så der ydes hurtig adgang til markederne for nye løsninger

- Finsk excellence i fokus områder, hvortil der skal etableres et center for energi og miljø i 2008

- De mest effektive internationale erhvervsnetværk skal skabes for at fremme finske firmaers udvikling. Ambitionen er at udvikle en samarbejdsmodel som kombinerer erhvervsliv, regeringsadministration, forskning og finansiering

\footnotetext{
120 Oplyst af Gaia Consulting OY.

${ }^{121}$ Sitra: Clean Tech Finland - improving the environment through business. Finland's national action plan to develop environmental business, January 2007, 44 sider.
} 
For at have den størst mulige effekt skal den finske indsats fokuseres mod udvalgte områder. Områder, som defineres af markedskræfterne. Derfor er der udvalgt 5 fokusområder med stærke firmaer og udviklingspotentiale:

- Vedvarende energi: Bionenergi er allerede en finsk styrke. Der er bl.a. flere store kedelproducenter. Der er også stærke leverandører til vindindustrien som ABB, Moventas og Winwind

- Genanvendelse af materialer: De stærkeste finske firmaer er Lassila \& Tikanjo, samt Kuusakoski. Der er mange nye innovationer, som videreudvikler affald til nye produkter og brugbare nye råmaterialer

- Ressourcebesparelser: Styring af materiale strømme er blevet opprioriteret betydeligt. Den finske metalindustri er en pionér i at udvikle sådanne systemer. Virksomheder, som kan nævnes, er: Metso, Outokumpu og Andritz

- Teknologier til energibesparelser: Der er favorable forhold for udvikling af teknologier til energibesparelser i Finland. Metso og Outokumpu er de største leverandører af teknologi til energibesparelser i industrien. ABB, Vacon og Nokia Capacitors er betydelige leverandører af teknologi til at spare elektricitet $\mathrm{i}$ industrien

- Vandbehandling: International efterspørgsel efter vandteknologi er stadig stigende. Vigtige finske aktører er Kemira, Pöyry og FCG

Det blev fremhævet, at en forudsætning for at den nationale handlingsplan kunne lykkes var, at den nye finske regering, som tiltrådte i april 2007, klart definerede en politik for miljøteknologisektoren. Det var forventet, at regeringen i 2007 ville lave en regeringshandlingsplan for sektoren. Heri skulle de forskellige ministeriers arbejde koordineres bedre fremover. Det blev betonet, at der skulle være mere samarbejde mellem offentlige og private aktører fremover. I det hele taget blev der efterspurgt mere fokus i regeringens politik.

Handlingsplanen fastslår ret direkte, at der er brug for en strategisk ejer af handlingsplanen, og at dette kun kan være regeringen. Det anbefales også, at der etableres et „miljøforum“ dannet af miljøvirksomheder. Dette miljøforum skal deltage i implementeringen af handlingsplanen.

I regeringens program 2007-2011 opstiller regeringen følgende forpligtelse for sig selv:

„...Finland has the potential to become a strong international player in the environmental technology business. This will be secured by investing in research and development for renewable energy and other environmental technology, and in product commercialization and by promoting domestic markets and developing the public procurement standards." 


\begin{abstract}
„The Government will draw up a long-term climate and energy strategy at the beginning of the current term. The strategy will define the principal objectives and means of Finland's climate and energy policy for the next ten years in the context of the European Union. It will also suggest measures to facilitate the adaptation to change ..." ${ }^{122}$
\end{abstract}

Denne forpligtelse fra regeringen må ses som et svar på anbefalingen fra Sitra om en strategisk ejer for handlingsplanen. Et supplerende svar fra regeringen kan ses i Finlands bæredygtighedsstrategi fra februar 2008. ${ }^{123}$ Heri beskrives, hvordan Finland skal løse en række miljøopgaver. Dette kædes sammen med udviklingen af ny teknologi og herunder miljøteknologi. En række tiltag nævnes, om end de ikke gøres helt så konkrete som man kunne ønske sig i en kontekst for styrket regeringsopbakning bag en stærk politik for miljøteknologi.

\title{
Efterspørgsel og brugerdrevet innovation
}

Den nationale innovationsstrategi for Finland blev udviklet med det formål at finde nye veje til at skabe konkurrencemæssige fordele for Finland som svar på den stadig øgede globale konkurrence. Efterspørgsel og brugerdrevet innovationspolitik blev i denne forbindelse identificeret som et indsatsområde. Dette fik Ministeriet for beskæftigelse og $ø$ konomi til i samarbejde med en række aktører at vurdere, hvilke efterspørgsels- og brugerdrevne innovationsområder, som det ville være perspektivrigt at udvikle. Og samtidig var formålet at udforme en handlingsplan for dette politikområde.

I august 2010 udgav Ministeriet for beskæftigelse og økonomi en større rapport om efterspørgsel og brugerdrevet innovationspolitik, hvori handlingsplanen var indeholdt. ${ }^{124}$ Det er værd at bemærke, at rapporten er generel for alle samfundsområder, og altså dermed ikke specielt målrettet miljøområdet. Selvom rapporten dermed favner bredt, er der dog plads til at gå i dybden på enkelte områder, bl.a. miljø.

I rapporten forklares, at formålet med efterspørgsel og brugerdrevet innovationspolitik er at skabe og sprede innovationer ved at styrke efterspørgslen efter innovationer og forbedre forudsætningerne for, at disse innovationer kan anvendes. Man kan nævne forskellige instrumenter, som kan bruges hertil, f.eks. offentlige udbud til at fremme specifikke innovationer eller at styrke efterspørgslen ved forbedret regulering og standardisering. Brugerdrevet innovationspolitik fremmer en bedre forståelse for brugernes behov og skal styrke brugerens rolle i innovationsaktiviteter.

\footnotetext{
122 Her citeret efter Petri Peltonen, Ministry of Employment and the Economy: Government input in boosting innovation in the field of Environmental Technology in Finland, marts 2008, 15 overheads. 123 Finlands strategi för et hållbart Finland. På väg mot hållbara val, Et nationellt og globalt hållbart Finland. Statsråd ets kanslis publikationsserie, 2/2008, 1. februar 2008, 136 sider.

124 Ministry of Employment and the Economy: Demand and User-driven Innovation Policy - Framework (part I) and Action Plan (Part II), august 2010, 102 sider.
} 
Målet er at forøge kommercialiseringen af den brugerdrevne innovation, dvs. innovation udviklet ved hjælp af brugerne for deres egen skyld.

Rapporten har 2 dele: en beskrivelse af rammerne for efterspørgsel og brugerdrevet innovation og en formulering af en handlingsplan. Den første del af rapporten beskriver karakteristika ved denne form for innovation. Den forklarer nødvendigheden af den nye tilgang til innovation og beskriver nøgleelementer i politikken: kompetence udvikling, reguleringsreform, nye arbejdsmodeller i den offentlige sektor, samt udvikling af forskellige incitamenter. Den anden del af rapporten er den konkrete handlingsplan for, hvilke anbefalinger der opstilles.

En række konkrete anbefalinger opstilles på forskellige områder:

- Opbygning af kompetencer og vidensbase på området

- Styrke efterspørgslen

- Forsøge at indtage en frontposition internationalt på området

- Fremme græsrodsaktiviteter

- Fremme effektivitet ved brug af instrumenter og metoder på området

- Spredning af metoder gennem netværk

- Vurderinger af effekten og ageren herefter

En række på 18 konkrete anbefalinger nævnes i handlingsplanen, og i forhold til miljø er det værd særligt at nævne følgende:

- Vurdering af effekten af regulering på innovationsaktivitet. Vi mangler stadig konkret viden om detaljerede forhold

- Forsøge at indbygge motivation til innovation i nye reguleringsaktiviteter

- Fremme standardisering

- Udvikling af modeller til at introducere investeringsintensive innovationer som demonstration og reference

- Brug af offentlige udbud ved at fremme forståelse og styrke hos de organisationer, som bruges i denne sammenhæng

- Deltagelse fra borgere og virksomheder skal fremmes ved at give mere detaljeret information om den offentlige sektors aktiviteter

- Større fokus på design, som får en stadig stigende betydning som en vigtig del af løsninger

I det internationale billede bliver efterspørgsel og brugerdrevet innovation til et kæmpestort marked. Finland har allerede en god position til at få gavn af denne mulighed. Det er dog en stor udfordring, idet mange instrumenter ikke har været testet i praksis.

Rapporten i form af beskrivelse og handlingsplan har på en række områder tendens til at blive for generel, men alligevel må det siges at være et meget betydeligt arbejde, som den finske regering har gjort for at fremme fokus på efterspørgsel og brugerdrevet innovation. Man må håbe, at implementeringen forløber konstruktivt og skrider fremad planmæssigt. 


\section{Innovationens nye form}

I september 2009 udgav den finske økonomiminister, i øvrigt sammen med den danske økonomiminister en rapport om innovationens nye form. Rapporten ses som et grundlag for at forstå udviklingen i innovation og dermed øge evnen til at formulere en ny innovationspolitik. ${ }^{125}$ Rapporten er også et input til OECD's arbejde med en ny innovationsstrategi.

En række forskellige områder gennemgås bl.a. miljø eller snarere miljøbekymringer, der skaber nye erhvervsmuligheder. Der er nævnt enkelte eksempler på virksomhedsstrategier, men rapporten går ikke i dybden på miljøområdet.

Rapporten udpeger også offentlige udbud, som er perspektivrige i at fremme en målrettet efterspørgsel.

\subsubsection{Panelet for miljøinnovation}

Et meget centralt initiativ i Finland var nedsættelsen af et Panel for miljøinnovation, som fungerede over en periode af 2 år i 2009 og 2010. Miljøministeriet var ansvarligt for Panelet, og der er udgivet en rapport om Panelets arbejde. ${ }^{126}$

Formålet med panelets arbejde har været at komme med forslag til at forbedre miljøpolitikken, så den bedre kan understøtte udviklingen og implementering af miljøinnovationer. Panelet beskæftigede sig især med behovet for miljøinnovationer, reguleringen og andre instrumenters rolle i miljøinnovation, nationale tilskud til miljøinnovation, samt EUkommissionens instrumenter til at fremme miljøinnovation.

Panelet har vurderet, at der er et betydeligt behov for at fremme miljøinnovation for at forbedre materialeeffektivitet og forhindre skabelse af affald. Der er især behov for innovationer i udvindingsindustrien, fødevareindustri, reparation og konstruktion, samt handel. Andre områder, hvor en forbedring af materialeeffektiviteten kan reducere belastningen af klimaet, blev også identificeret. Sammen med innovation i processer og produkter er der et stort behov for at fremme innovationer i tjenester og løsninger, som kan støtte miljømæssige gode forbrugsmønstre.

Selvom man fandt, at regulering havde en vis effekt på innovation, var effekten fra reguleringen større ved spredningen af innovationer. Samtidigt anbefaler Panelet, at man forsøger at fokusere mere på, hvordan nye instrumenter kan fremme udviklingen af innovation og skabe nye løsninger.

\footnotetext{
125 Ministry of Employment and the Economy, Erhvervs- og Byggestyrelsen, Fora og OECD: New Nature of Innovation, September 2009, 96 sider.

${ }^{126}$ Ministry of the Environment: Ekoinnovaatiot ja ympäristöpolitikka. Rapportti ympäristöinnovaatiopaneelin toiminnan tuloksista ja suosituket jatkotoimenpiteiksi (Eco-innovation and environmental policy. Report of the environmental innovation panel and recommendations for further measures). Marts 2011, 39 sider.
} 
Man fandt også, at der var en betydelig fremtidsforståelse i forbindelse med miljøinnovationer, men desværre var der en svag anvendelse af denne fremtidsforståelse. Især hos mindre og mellemstore virksomheder er der er stort behov for at udnytte denne forståelse. I forbindelse med reguleringsprocesser og andre måder at påvirke offentligheden på er der dermed et stort behov for at forsøge at forstå en mulig positiv teknologiudvikling.

Om national tilskudspolitik fandt Panelet, at der var tilstrækkelig med tilskudsmuligheder, men der manglede en fokus på at fremme materialeeffektivitet. Man anbefalede, at tilskudspolitikken blev evalueret bedre. Det blev vurderet, at der var behov for at gøre tilskudssystemet mere effektivitet og få det til at virke bedre sammen med EUkommissionens tilskudspolitik.

På internationalt plan anbefalede Panelet, at man i Finland skulle være bedre til at fremme EU 2020 strategien på innovationsområdet og tilmed gennemføre en national implementering af EU's 2020 strategi. I forhold til FN's og OECD's arbejde på området med miljøinnovation og grøn vækst ønskede man, at Finland skulle fremme synergier mellem miljømål og grøn vækst.

Som en afslutning anbefaler Panelet, at Finland laver en strategi for miljøinnovation. Grundlaget for strategien skal være at målrette efterspørgslen og behovet for miljøinnovation, restrukturering af økonomien og mulighederne for udvikling af miljøteknologi. Strategien skal definere målene for Finland i forbindelse med udviklingen af miljøinnovation og ligeledes definere instrumenter for at fremme teknologiudviklingen, samt andre udviklingsbehov. Strategien skal også bruges til at styrke samarbejdet mellem de forskellige aktører og skabe nye stærke netværk og aktiviteter.

På Panelet hjemmeside er der en oversigt, hvor der er 8 rapporter, som er udarbejdet som led i arbejdet. De er på finsk. Der er ligeledes en række overheads, nogle på engelsk, fra et seminar afholdt den 8. december 2010.

\section{Klima og energi}

Klima og energi er et helt centralt tema i arbejdet med miljøteknologi i Finland, som i de fleste andre lande. Regeringen vedtog i november 2008 en ny klima- og energipolitik for Finland med detaljer om klima- og energipolitiske virkemidler til 2020. Regeringen fremlagde også i 2009 en rapport om langsigtet klima- og energipolitik, kaldet en Foresight Report frem til 2050. ${ }^{127}$ I dette omfattende værk på 190 sider beskrives klima- og energipolitikken indgående. Målet er mindst $80 \%$ reduktion af klimagasserne i 2050. $38 \%$ af energiforbruget skal dækkes af vedvaren-

127 Statsrådets framtidsredogörelse om klimat- og energipolitiken: vägen till ett utsläppssnålt Finland, Statsrådets kanslis publikationsserie 29/2009, 190 sider. 
de kilder i 2020 og denne andel skal være 60 \% i 2050. Rapporten tager ikke endelig stilling til atomkraft i Finland, men det beskrives, at atomkraft kan være et instrument, hvis alternativerne har for store omkostninger, når de nuværende reaktorer skal udskiftes i 2030-40.

I forbindelse med arbejdet for udfasning af fossil energi må man huske på, at Finland er gået en anden vej end de fleste andre lande på atomkraftområdet. Blandt finnerne er der en betydelig større andel af befolkningen, som er positive overfor atomkraft end i mange andre lande. Miljøbevægelsen har ikke haft held med at være kritisk. Finland fortsætter med at satse på udbygning af atomkraft. Man har 4 reaktorer i Finland og en ny reaktor er snart klar til at åbne. Hertil er yderligere 3 nye reaktorer mere eller mindre besluttet. Atomkraftværkerne leverer p.t. ca. $30 \%$ af elektriciteten i Finland. Det er blevet hævdet, at Finland er det land i verden, som producerer mest radioaktivt affald pr. person. Denne udbygning af atomkraften vil givetvis sikre Finland billig energi til bl.a. industrien, men samtidig gøre det vanskeligt at fremme energieffektivitet og -besparelser, samt fremme af vedvarende energi.

I forbindelse med klima- og energipolitikken bør man også nævne Sitras energiprogram 2008-2012, som har været ganske effektiv i at promovere energieffektivitet frem. ${ }^{128}$

\section{Naturressourcer}

Sitra har endvidere udviklet en strategi for anvendelse af naturressourcer på en intelligent måde. ${ }^{129}$ Dette er en ganske kort strategi, som på en ny måde forsøger at vurdere anvendelsen af naturressourcer i et tidsperspektiv frem til 2030. Strategien taler om, at Finland skal gå foran på dette område. Visionen skal virkeliggøres ved at bruge 4 strategiske egenskaber:

- Finland har en blomstrende bioøkonomi, der generer stor tilvækst

- Finland bruger og genanvender materialestrømme effektivt

- Regionale ressourcer skaber både national vækst og lokal velfærd

- Finland tager initiativer og fører an på emner om naturressourcer

Strategien har som sit konkrete omdrejningspunkt 18 specifikke anbefalinger, som skal bane vejen fremad. Her kan nævnes nogle af disse:

- Etablering af bioraffinaderier

- Påvirkning af international politik

- Strategier for specifikke naturressourcer

\footnotetext{
128 Pressemeddelelse fra Sitra om programmet, og en lille folder om energiprogrammet fra Sitra. ${ }^{129}$ Sitra: A natural Resource Strategy for Finland: Using natural resources intelligently, april 2009, 12 sider.
} 
I det hele taget kan denne strategi virke en anelse luftig og meget overordnet, men man kan ikke afskrive en sådan strategi, fordi vækst og velfærd i høj grad hænger sammen med anvendelsen af naturressourcer, også på den mest intelligente måde. Så man må afvente en konkretisering af en sådan strategi og gennemførelsen heraf for at se den fulde effekt.

Som en anden strategi kan man nævne en rapport fra Statsrådskansliet om bioøkonomi i $2010 .^{130}$ Denne strategi bygger videre på Sitras strategi og har sin rod i den ekspertise i fremskrivninger af samfundsudvikling, teknologi etc., som er blevet udviklet i Finland.

\subsubsection{Mod grøn vækst? - Finlands position i miljøteknologi}

I maj 2011 udgav Tekes en publikation om grøn vækst og en status for miljøteknologi i Finland. ${ }^{131}$ Overskriften er en konsekvens af, at grøn vækst bliver stadig vigtigere som tema, mens tilføjelsen viser mere konkret, at det handler om miljøteknologi. Publikationen er resultatet af et projekt finansieret af Tekes og udført af firmaerne Advansis og Etlatieto samt Aalto University, Organization and Management kaldet FOPET om Finlands muligheder indenfor miljøteknologi. Projektet startede i november 2009 og er afsluttet i marts 2011. ${ }^{132}$

Publikationen eller projektet gennemfører 3 analyser. Først analyseres miljøteknologiske investeringer på globalt niveau og det grønne element i vækstpakker i forskellige lande som følge af krisen. I anden del af projektet undersøges miljøteknologisk specialisering i forskellige lande. Og i sidste del af projektet undersøges biobrændsler og elektriske biler som eksempler i Finland på, hvad der kan gøres på 2 særligt vigtige områder.

Publikationen undersøger en række landes investeringer i miljøteknologi og finder, at det er nemmest at følge vedvarende energi, som en investeringsindikator, grundet det forarbejde som OECD har lavet på området. Det viser sig, at lande som Sydkorea og Kina har investeret betydeligt og vel også mest globalt set i miljøteknologi, som følge af grønne investeringspakker og hjælp under finanskrisen.

I forbindelse med undersøgelsen af forskellige landes styrker eller specialisering i miljøteknologi konkluderer rapporten, at Finland ikke har en sådan klar specialisering, men er decideret svag på enkelte områder som f.eks. solenergi. Og Finland synes at have vanskeligt ved at holde sin delspecialisering på vindenergiområdet.

I forbindelse med grøn vækst analyseres endvidere nøglefaktorer for grøn vækst, og disse følger OECD’s arbejde fra interim rapporten 2010, jvf.

\footnotetext{
${ }^{130}$ Statsrådskansliet: Bioøkonomi: vurdering af behovet for en national strategi, nævnt af Gaia Consulting. 131 Tekes: Towards green growth? - The position of Finland in environmental technologi, april 2011, 61 sider. 132 Tuomo Nikulainan: Towards a green post-crisis economy? - Finnish opportunities in environmental technologies, Overheads from Ministry of the Environment - Tekes seminar, 8. December 2010, 17 overheads.
} 
ovenfor under indledningsafsnittet. Som en generel konklusion slås fast, at en fornuftig strategi for grøn vækst omfatter en ganske substantiel transformation af forbrugsmønstre, industrielle strukturer og teknologier.

I Finland bliver miljøteknologi generelt fremmet i forbindelse med klimastrategien fra 2008, den nationale klima- og energistrategi, der som mål har en andel på $38 \%$ vedvarende energi af Finlands totale forbrug af energi i 2020, samt koblingen til EU's arbejde med ETAP. Det kan nævnes, at Tekes alene i 2010 havde tilskud til investeringer i miljøteknologi for 245 mio. EUR på en bred front og ikke alene til energiteknologier. Tekes har også iværksat et nyt program for grøn vækst 2011-15, se nedenfor.

Generelt konkluderes, at Finland stadig ikke har en klar og tydelig strategi og politik for grøn vækst, selvom der er ganske mange initiativer i gang. Og dermed efterspørges en sådan klar strategi.

I den internationale analyse vurderes som noget ganske interessant antallet af forskellige landes patenter indenfor det miljøteknologiske område. For Finlands vedkommende er det vurderet, at Finland har 125 virksomheder, som har taget patent eller patenter på dette område. Heraf er de fleste meget teknologispecifikke patenter inden for maskinindustrien. Den økonomiske tyngde af disse 125 virksomheder er ca. 12.000 ansatte og en omsætning på 3,5 mia. EUR.

Især på grund af klimapolitikken internationalt er biobrændstoffer og el-biler et meget interessant marked, også i Finland. Landet har en vis styrke på området. Det største finske oliefirma, Neste Oil Oyj, har investeret i raffinaderivirksomhed til biobrændstoffer i Finland og internationalt, baseret på firmaets teknologi. En anden virksomhed, som er ny i oliesektoren, St1 Oy, har udviklet en ny metode til at producere ethanol fra affald fra fødevaresektoren. Den finske papirindustri har undersøgt mulighederne for at bygge nye biodieselfabrikker baseret på træmasse. På området for el-biler har den eneste finske producent, Valmet Automotive, startet en produktion til kunder i Norge, Danmark og USA. Der har også været en række andre initiativer på området i Finland.

Rapporten vurderer, at det for nuværende i Finland relativt lille marked for biobrændstoffer og el-biler kan bidrage til grøn vækst i landet. Forudsætningerne er bl.a., at 2. generations biobrændstoffer, dvs. biobrændstoffer baseret på træ og affald, får en succesfuld udvikling, og at hjemmemarkedet kan vise en efterspørgsel efter el-biler og systemer til at forsyne el-biler.

Rapporten konkluderer, at grøn vækst kan have store perspektiver for Finland, men det forudsætter stærk politisk handling og betydelige systemændringer.

Regeringsprogrammet fra juni 2011 giver en række svar på rapporten fra Tekes. ${ }^{133}$ I indledningen af regeringsprogrammet står, at det 
fremtidige Finland skal være et kuldioxidneutralt samfund, og at Finland skal blive det ledende land på området for miljøteknik, og at Finland skal udvikles til verdens mest miljøvidende nation.

Under energipolitikken beskrives på 2 sider, hvordan man skal fremme vedvarende energi og energieffektivitet. ${ }^{134}$ Der skal bl.a. udarbejdes et program for at mindske olieafhængigheden i Finland. Energiteknologien skal fremmes gennem innovationspolitiske tiltag, forskning og produktudvikling samt gennem uddannelse. I spørgsmålet om solenergi, energieffektivitet og -besparelser skal man fremme innovationer og forsøge at få udviklingen af produkter til at blomstre. På eksportområdet skal Finland ligeledes gøre det bedre, især på nye markeder. Tilskudssystemet skal udvikles for at kunne have større effekt. Tilskud til vedvarende energi skal vurderes inden udgangen af 2012.

Under afsnittet om miljøpolitikken beskrives, at Finland skal udvikles til et kuldioxidneutralt samfund og et foregangsland indenfor miljøkompetence, ren teknik og nye arbejdspladser. Målet er at skabe forudsætninger for økologisk bæredygtig vækst og nye arbejdspladser. De muligheder, som ny teknik og informationsteknikken tilbyder, skal nyttiggøres for at øge materiale- og energieffektiviteten og mindske miljøbelastningen. Regeringen vil omarbejde sin bæredygtighedsstrategi og fastlægge mål og principper for bæredygtig udvikling.

Generelt må man sige om regeringens nye program, at det virker meget positivt i sine erklæringer om at gøre en større indsats indenfor området miljøteknologi. Derom kan der ikke herske tvivl. Det bliver dog ikke skrevet i detaljer, hvad der præcist skal ske, og dette er nok en svaghed, men meget forståeligt, fordi regeringsprogrammer typisk laves ret hurtigt i en politisk proces.

\section{Tekes' finansiering af miljøteknologi}

Tekes er Finlands største tilskudsyder på området for miljøteknologi. En opgørelse over Tekes samlede tilskud til energi- og miljøteknologiske programmer i perioden 2006-2010 viser, at Tekes i de forskellige år finansierede: ${ }^{135}$

2006: 50 mio. EUR

2007: 150 mio. EUR

2008: 200 mio. EUR

2009: 225 mio. EUR

2010: 245 mio. EUR

\footnotetext{
134 Regeringsprogrammet side 45-47.

135 Tekes: Towards green growth, citeret tidligere, side 30.
} 
I 2010 har Tekes dermed samlet ydet tilskud på 245 mio. EUR til energiog miljøteknologiske programmer. Støtten er givet til en række forskellige områder, og vedvarende energi har ikke fået en speciel prioritering sammenlignet med andre lande. Energieffektivitet har dog fået en særlig opmærksomhed i Finland. OECD har også i sin vurdering af finsk miljøpolitik fundet, at Finland kunne gøre mere for at fremme miljøteknologisk innovation ved f.eks. at bruge grønne udbud, miljømærker, involvere industrien og andre aktører og overveje, hvordan forskellige instrumenter kan fremme miljøteknologisk innovation. ${ }^{136}$

Tekes har siden slutningen af 90'erne haft og har en række forskellige programmer, som støtter miljøteknologiske programmer. 19 programmer er nævnt i en tabel i Tekes publikationen om grøn vækst. ${ }^{137}$

Især kan man fremhæve programmerne:

- BioRefine til 200 mio. EUR i perioden 2007-2012,

- Kestävä yhdyskunta, som er et program til bæredygtig udvikling på byggeriområdet, til 100 mio. EUR i perioden 2007-2012

- Et program for brændselsceller til 144 mio. EUR i perioden 2007-2013

- Et program om vedvarende energi til 95 mio. EUR i perioden 2010-2014

Tekes iværksatte i 2011 et program om grøn vækst mod en bæredygtig fremtid med særlig fokus på begrænsede naturressourcer, forbedret energi- og materialeeffektivitet. ${ }^{138}$ Programmet skal vare i perioden 2011-2015 og har 79 mio. EUR til sin rådighed. Programmet anskuer grøn vækst ud fra et perspektiv om systemændringer. Konkret vil man søge at støtte skabelsen af innovation ved at fremme markante spring i energi- og materialeeffektivitet, samt at skabe grundlaget for udviklingen af nye værdinetværk baseret på grøn vækst.

Programmets mere praktiske midler er:

- At udvikle strategiske kompetencer som et fundament for grøn vækst

- At producere og sprede viden om den fremtidige udvikling med det formål at støtte virksomheder i en fornyelse af deres businessstrategier

- At fremme udviklingen af værdinetværk og udviklingen af platforme for bæredygtig vækst

\footnotetext{
136 OECD: Environmental Performance Reviews: Finland. OECD 2009.

137 Tekes: Towards green growth, citeret tidligere, side 29.

138 Pressemeddelelse fra Tekes den 19. januar 2011, samt programmanager Tuomo Suortti: Green Growth Towards Sustainable Future 2011-2015,12 overheads, og Tekes: Towards green growth? tidligere citeret, box 2 , side 12 .
} 
Programmets arbejde med de praktiske midler får støtte fra et samarbejde mellem flere ministerier, Det finske Academy, samt flere centre for ekspertise og strategi.

Den måde, som programmet er omtalt på, virker meget overordnet og nok ret vanskeligt tilgængeligt for virksomheder og forskningsinstitutioner eller ansøgere generelt. Man må håbe, at der kommer mere konkret materiale, så det bliver lettere at forstå præcis, hvad der menes.

\subsection{Finske eksempler med international succes}

Hvis man skal beskrive virksomheder og teknologier i Finland, som har succes i international sammenhæng må man starte med at omtale Clean Tech Finland. Clean Tech Finland er et finsk netværk, der har til formål fremme netværkssamarbejde i den finske cleantech industri koblet til forskning samt at støtte finsk cleantech internationalt. Clean Tech Finland blev oprindelig udviklet af Sitra, men ejes i dag af Sammenslutningen af Finsk Industri og styres af Finpro. Clean Tech Finland har udgivet en publikation om innovative teknologier til et renere miljø. ${ }^{139}$ Denne publikation gennemgår en række relevante teknologitemaer, som vand, affald, energieffektivitet, monitering, biobrændsel, transport, og økobygninger. Hertil nævnes de vigtigste finske firmaer på de enkelte områder. Clean Tech Finland har også på sin hjemmeside et antal succesrige cases, som det er værd at kigge på. ${ }^{140}$

En interessant eksempelsamling er også lavet af organisationen Hich Tech Finland, hvor der anvendes ca. 2 sider til at beskrive hvert eksempel indenfor miljøteknologi. ${ }^{141}$ Eksempelsamlingen er startet i 2005 og i 2011 er der tilføjet over 30 nye artikler. Eksempler er velskrevne og omtaler enkeltvirksomheder.

I Finland er der en række cleantech klynger eller geografiske grupperinger, som tiltrækker sig opmærksomhed. Man kan nævne Lahti, Kuopio, Oulo and Helsinki regionen, hvor det er vurderet, at $60 \%$ af Finland's cleantech virksomheder er placeret og $80 \%$ af forskningen. Denne geografiske samling er en stor styrke.

Når man nævner klynger i Finland, bør man også nævne energiklyngen af virksomheder i Vasa regionen, som står for ca. 29 \% af Finlands energiteknologieksport. Denne klynge af energivirksomheder er Europas største, og 120 virksomheder indgår i samarbejdet og beskæftiger ca. 10.000 personer, samt omsætter for 4 mia. EUR om året. Målet for klyngen er at begrænse klimagasser. Dette gøres ved at udvikle produk-

\footnotetext{
139 Clean Tech Finland: Innovative technologies for clean environment 2007, 16 sider.

140 Clean Tech Finlands hjemmeside.

${ }^{141}$ High Tech Finland: hjemmeside om eksempler på en ergi og miljø, langt over 100 eksempler.
} 
ter og tjenester, som forbedrer energieffektiviteten fra produktion til slutanvendelse. Virksomhederne arbejder med dieselmotorer, kraftværker, systemer til distribution af elektricitet, samt vindkraft. De vigtigste virksomheder er Wärtslillä, ABB, VAMP, Arcteq, Vacon, Citec, The Switch, VEO, Mervento og EPV.

En rapport om Finnish Cleantech Venture blev udgivet i 2011. ${ }^{142}$ Publikationen beskriver en række temaer, som forskning og udvikling, og den beskriver ligeledes 3 centrale cleantech områder. Først skovindustrien, hvor der nævnes 4 spændende virksomheder: Metgen, Ultranat, BT Wood og Gasek. Dernæst elektrificering af transporten, hvor der også nævnes 4 interessante virksomheder: AMC Motors, Electric Ocean, European Batteries og Visedo. Og sidst forbedringer af ressource- og energianvendelse, hvor der nævnes 3 virksomheder som tiltrækker sig opmærksomhed: Savo-Solar, Enersize og One1.

Et firma, AkkuSer Ltd., er blevet kendt på at skabe en god virksomhed ved at genanvende batterier og accumulatorer brugt i netfrie produkter, som kameraer, mobiltelefoner og computere. AkkuSer's genanvendelsemetode hedder Dry Technology og er unik på verdensskala. Metoden kan separere de forskellige metaller, så de kan bruges igen for $90 \%$ vedkommende. AkkuSer genanvender de fleste affaldsbatterier fra de pågældende produkter i Finland og Estland, og ca. halvdelen af affaldsbatterierne fra Norge og Sverige.

Kemira, en kendt finsk kemikalie virksomhed, leverer kemikalier til mange formål, bl.a. til rensning af vand. Firmaet har bl.a. udviklet DesinFix, et klorinfrit desinfections system til at desinficere vand på kort tid. Det bruges på spildevandsrenseanlæg. Fordelene ved DesinFix er, at det har et lavt energiforbrug og billige driftsomkostninger, så det er betydeligt billigere end mange alternativer.

Globe Hope Ltd. har udviklet et designkoncept, der skaber nye individuelt designede produkter af affaldsmaterialer. Herved skabes nye kvalitetsprodukter, som har vist sig at kunne konkurrere som modeprodukter. Især reduceres materialeforbruget ved processen.

I Finland har man gjort meget for at nedbringe miljøbelastningen fra papirproduktion. Traditionelt bruges der meget vand, energi og kemikalier i produktionen af papir. Wetend Technologies Ltd. har udviklet et nyt kemikaliesystem, kaldet TrumpJet kemikalie blandings system, som tilsætter kemikalier og additiver, samt bruger recirkuleret væske fra hovedprocessen. Herved er der brug for betydeligt færre kemikalier og additiver. Der spares store mængder vand og energi og kvaliteten af produkterne bliver bedre, fordi processen styres optimalt. Firmaet hav-

142 Nordic Cleantech Open, Lahti science and Business Park: Finnish Cleantech Venture Report 2011, 2011, 14 sider. 
de allerede i 2007 leveret 170 systemer til 20 forskellige lande og $90 \%$ af produktionen eksporteres. ${ }^{143}$

Finsk skovindustri er også gået over i genanvendelse af papir. Virksomheden UPM har bl.a. i juli 2011 åbnet et genanvendelsesanlæg i Shotton i Wales. Det kan også nævnes, at UPM er den største producent af 100 $\%$ genbrugt avispapir i England med genanvendelse af 640.000 tons. ${ }^{144}$

Et vandrensningsfirma, Biolan Oy, har udviklet et lille rensningsanlæg konstrueret til at rense spildevandet fra feriehuse. På grund af den stigende spildevandsbelastning fra feriehuse og fritliggende huse bliver lovgivningen stadig strammere for udledning af spildevand herfra. Derfor er der udviklet mindre anlæg til at rense dette vand, og Biolan Oy er et af disse firmaer bag denne udvikling. Anlægget renser gråt spildevand fra husholdninger, hvor anlægget er placeret over jorden, optimalt til klippeunderlag, med et organisk filter tilkoblet, som producerer et kompostérbart restprodukt. ${ }^{145}$

Beneq Ltd. er leverandør af udstyr og coating teknologi. Beneq udvikler applikationer og udstyr til cleantech og vedvarende energi områderne, specielt i glas, til brug i solenergi, og nye tynde belægninger. Beneq leverer samlede systemer til belægning.

Moventas Ltd. er en af de største producenter af gear til vindmøller i verden. Moventas leverer også service til vedligeholdelse af gear. Moventas' ekspertise er baseret på at kombinere årtiers ekspertise med ny helt moderne teknologi. Moventas har ca. 1.000 ansatte i 10 lande.

AW-Energy Ltd. er en nystarted virksomhed, som udvikler ny teknologi til at producere energi fra bølger. Den nye WaveRoller teknologi udnytter som noget nyt bølgeenergi fra bunden af oceaner. Styrken i teknologien er, at den tilbyder en mulighed for en mere kosteffektiv tilkobling til energinettet på land. Det første forsøgsanlæg tages i brug i 2011 i Portugal.

\subsection{Arbejdet med efterspørgselssiden i Finland}

I Finland har man i forbindelse med Innovationspanelet arbejdet mere systematisk med efterspørgselssiden.

Man har været inspireret af, at ét af de vigtigste spørgsmål i innovationspolitikken de senere år har været, hvordan man skaber efterspørgsel efter innovationer. Og hvordan man systematisk udvikler efterspørgslen på innovationer ved hjælp af regulering, idet dette kan være en sty-

\footnotetext{
143 Ministry of the Environment: Facts on environmental protection, maj 2007, 2 sider.

144 Den finske ambassade, London: Finsk skovindustri godt eksempel på udvikling af renere teknologier. 12. juli 2011, 2 sider (her oversat til dansk).

145 Ministry of the Environment: Facts on environmental protection, maj 2007, 2 sider.
} 
ringsmekanisme, som fører til, at der satses på innovationer, som kan løse vanskelige problemer for samfundet.

I rapporten om reguleringens indvirkning på miljøinnovationer ${ }^{146}$ diskuteres, hvordan reguleringer indvirker på miljøinnovationer, og hvordan reguleringer kan udvikles, så man mere effektivt kan fremme miljøinnovationer, ibrugtagningen og spredningen af dem. Især er den regulering, som styrer affalds- og materialeeffektivitetssektorerne og disses påvirkning af efterspørgslen på innovationer, undersøgt nærmere. I udredningen drøftes konkrete udviklingsforslag til, hvordan man kan forbedre regler og styringsmekanismer med påvirkning af et område. Endvidere præsenteres en del nye styringsmekanismer for at fremme positive effekter for miljøinnovationer.

I en anden rapport har Panelet for miljøinnovation givet en status og undersøgt ledende markeder, sådan som temaet om „Lead Markets“ har udviklet sig de senere år. ${ }^{147}$ Det kan dog bemærkes, at rapporten var initieret af Tekes og Ministeriet for beskæftigelse og økonomi, og var en opfølgning af arbejdet med brugerdrevet innovation, jf. ovenfor. Rapporten analyserer for Finlands vedkommende de samme 6 sektorer, som EU-kommissionens arbejde for „Lead Markets“ eller „Lead Market Initiative" (LMI) har udpeget, nemlig e-sundhed, biobaserede produkter, genanvendelse, bæredygtigt byggeri, vedvarende energikilder og beskyttelsestekstiler. Formålet er at udvikle efterspørgslen efter innovative produkter og tjenester.

Rapporten om ledende markeder konkluderer, at der på mange måder er betydelig forskel på EU-kommissionen tilgang og den virkelighed, som reguleringsmæssigt eksisterer i medlemslandene. For at promovere EU-kommissionens arbejde foreslås derfor, at hvert medlemsland skal definere en klar målsætning for et ledende marked. Rapporten argumenterer for, at EU tilgangen er for bred på de enkelte sektorer, og at der skal arbejdes med mere præcise sektorer eller undersektorer. Dette er dog ikke uden problemer, idet der hurtigt fremkommer for mange undersektorer.

Undersøgelsen anbefaler, at der nationalt etableres en „management enhed" til at koordinere aktiviteter indenfor hver LMI sektor.

I Finland er der desuden for nylig påbegyndt et nyt projekt om mulighederne for at bruge reguleringsinstrumenter til at promovere genanvendelse af plastik.

\footnotetext{
146 Ympäristöministeriö: Sääntelyn ympäristöinnovaatiovaikutukset, (Reguleringens indvirkning på miljøinnovationer) februar 2011, 34 sider.

147 Työ- ja elinkeinoministerio, Arbejds- og næringsministeriet, og Ministry of Employment and the Economy: Edelläkävijämarkkina-aloite ja innovaatiotoiminta (Innovation policy and the Lead Market Initiative for Europe), august 2010, 146 sider.
} 


\subsection{Konklusioner på Finlands aktiviteter}

Informationer om antallet af miljøteknologiske virksomheder i Finland giver grundlag for at vurdere, at tallet bør fastsættes til ca. 400 virksomheder. Clean Tech Finland opgør dog antallet af cleantech virksomheder til ca. 2.000, men dette tal kræver en mere fyldestgørende dokumentation og beskrivelse, førend man kan bruge det mere aktivt. Det er Cleantech virksomhederne selv, som har været med til at fastsætte dette tal, hvorfor der kan være en vis egeninteresse i, at tallet er stort. Sektoren opgøres til at have en omsætning på 12-17 mia. EUR i 2010, hvor de 25 $\%$ største virksomheder står for 80 \% af omsætningen. Clean Tech Finland fastsætter denne omsætning til 18 mia. EUR. Der er behov for en mere præcis tilgang til, hvor mange virksomheder der er i Finland, og hvor stor sektoren er i Finland. En statslig myndighed må nødvendigvis have det endelige ansvar for opgørelsen.

Eksporten fra sektoren i Finland bliver heller ikke opgjort detaljeret og opgøres kun lejlighedsvis overordnet. I 2006 blev det vurderet, at eksporten kunne opgøres til ca. 2,25 mia. EUR. Clean Tech Finland fastsætter for året 2010 dette til 75 \% af omsætningen, dvs. de 18 mia. EUR og følgelig fås 13,5 mia. EUR som eksporttal. På denne baggrund er det meget vanskeligt at fastsætte en specifik eksportstørrelse for Finland. Igen mangler der en klar oversigt over eksporten fra sektoren for miljøteknologi i Finland.

I Finland er det vel ikke forkert at fremhæve, at det er Sitra, den uafhængige Finske innovation Fond, som har fremmet temaet om miljøteknologi på den mest aktive måde. Sitra startede først sit 3-årige miljøprogram Clean Tech Finland i 2004 med en betydelig indsats for at fremme miljøteknologi. Ligeledes har Sitra promoveret energiområdet i et program fra 2008. Sitra lavede i 2007 Finland's første handlingsplan for miljøteknologi eller cleantech. Sitras vision var, at Finland skal være det mest kendte cleantech land i verden i 2012. Sitra fremhæver i sin handlingsplan, at der er brug for en strategisk ejer af handlingsplanen, og at dette kun kan være regeringen. Regeringen svarede, nok lidt indirekte, ved at tage opfordringen op og skrive kort herom i sit regeringsprogram fra 2007 og i sin bæredygtighedsstrategi fra 2008, at det er regeringens prioritering. Det er vel i international sammenhæng ikke helt almindeligt, at en uafhængig fond ganske vist ejet af regeringen laver en handlingsplan for hele landet. Det virker som om regeringen ikke medvirker i første række, og det er vel også det, som Sitra bemærker i sin handlingsplan. Regeringen må have følt sig tilpas med, at Sitra går i front og markerer, hvad Finland har brug for. Givetvis er dette ikke noget problem, hvis alle virksomheder i Finland opfatter Sitra, som regeringens forlængede arm, hvilket nok også er tilfældet. En vurdering må være, at det ville være bedre, hvis regeringen havde en mere klar formuleret politik på området, ikke mindst når der synes at være meget store ambitioner i Finland for området. I en sådan formulering bør regeringen også passe 
på med ikke at introducere for mange ideer eller koncepter, som det ses med arbejdet om naturressourcer og bioøkonomi. Det kan let skabe forvirring om, hvor Finland skal bevæge sig henad.

Finland er måske verdens stærkeste forsknings- og innovationsland og meget af arbejdet med miljøteknologi er koblet til forskning og innovation mere bredt, sådan som man gør i det finske samfund. Her kan man nævne det store arbejde, man har lavet i Finland, for efterspørgsel og brugerdrevet innovation, hvor miljøaspektet er ét blandt flere. Denne satsning på innovationens nye form må vurderes langt stærkere i Finland end i de andre nordiske lande. Det virker som om Finland arbejder meget målrettet med at finde konkrete midler til at fremme brugerdreven innovation. Og i øvrigt i tæt samarbejde med OECD's innovationsarbejde.

Et vigtigt initiativ i Finland var nedsættelsen af Panelet for miljøinnovation, som Miljøministeriet var ansvarlig for. Under Panelet for miljøinnovations deltagelse blev der udgivet en række spændende rapporter om miljøinnovation i Finland med Miljøministeriet som ledende arbejdskraft. Panelet beskæftigede sig især med regulering og tilskud. Panelet anbefaler i slutningen af 2010, at Finland laver en national strategi for miljøinnovation, hvor der er klare mål og fokus på instrumenter til udvikling af miljøteknologi.

Det nærmeste man kommer på en ny strategi for miljøteknologi i Finland, er Tekes' publikation om grøn vækst - Finlands position i miljøteknologi. Diskussionen om grøn vækst havde allerede kørt i Finland i et par år. Det konkluderes i rapporten, at Finland stadig ikke har en klar strategi og en tydelig politik for grøn vækst, selvom der er ganske mange initiativer i gang. Denne strategi er ganske perspektivrig. Regeringens program fra 2011 giver en række svar på strategien fra Tekes. I indledningen står bl.a., at Finland skal blive det ledende land på området for miljøteknologi - en ganske flot ambition.

På efterspørgselssiden har Finland lavet noget så spændende som en publikation om reguleringens indvirkning på miljøinnovation. På en så målrettet måde har de andre nordiske lande ikke arbejdet med efterspørgselssiden. Kun fremtiden kan vise, hvordan der bliver fulgt op herpå.

De stærkeste initiativer i Finland kommer fra Sitra og Tekes, hvor der kommer fremadskuende og perspektivrige strategier, som må siges nærmest at være nationale for Finland. Regeringen følger også op med erklæringer og opbakning, om end dette kunne gøres mere aktivt i form af en klar regeringsstrategi. 



\section{Islands indsats for miljøteknologi 2004-2011}

I Island bruges begrebet „umhverfistækni“, som vel nemmest kan oversættes til miljøteknologi og dermed det mest oplagte at anvende i dette afsnit for Islands vedkommende. Island er meget international, og derfor bruges begrebet cleantech i et vist omfang.

\subsection{Islandsk erhvervslivs aktiviteter indenfor miljøteknologi}

Der foreligger ingen officielle opgørelser over størrelsen af det islandske erhvervsliv indenfor miljøteknologi. Virksomheder i sektoren etablerede samarbejdsgruppen Clean Tech Iceland i foråret 2010, og denne gruppe har nu 14 virksomheder. Baseret på oplysninger fra Clean Tech Iceland, Det islandske Miljøministerium og konsulent Stefán Gíslason, Environice må det vurderes, at størrelsesordenen i Island er på lidt over 40 virksomheder, som arbejder helt eller delvist med miljøteknologi. En konkret opgørelse viser 43 virksomheder. Af disse arbejder omkring 25 med udvikling og salg af energiteknologi, herunder har 8 virksomheder specialiseret sig i udnyttelsen af geotermisk energi.

Der foreligger heller ingen oplysninger om antal ansatte i disse miljøteknologiske virksomheder. Fra en sammenligning af data fra Islands industriforbund (SI) og fra nogle af virksomhedernes websider, må det vurderes, at samlet set kan disse godt 40 virksomheder have omkring 1.200 medarbejdere. Her henvises der til total antal ansatte, men man bør huske, at mange af virksomhederne også arbejder med andre områder end miljøteknologi. Der er ikke foretaget en vægtning af dette, og af denne grund er det vanskeligt at fastslå det faktiske antal medarbejdere, der arbejder direkte med miljøteknologi. ${ }^{148}$

Der foreligger heller ingen officielle oplysninger om omsætning i de miljøteknologiske virksomheder i Island. Groft anslået kan den samlede årlige omsætning være omkring 700 millioner DKK. Dette omfatter også omsætning i virksomhedernes andre aktiviteter, hvor dette er tilfældet. 
De fleste af de pågældende virksomheder er små. Således skønnes det, at 26 af de 43 selskaber, der er medtaget i vurderingen har 3 eller færre ansatte, 6 virksomheder har 4-10 ansatte og andre 6 har 11-50 ansatte. Baseret på disse tal er der kun 5 virksomheder med mere end 50 ansatte. To af de største virksomheder har specialiseret sig i modtagelse, transport og sortering af affald til genanvendelse. Tre af de største virksomheder arbejder med forskning, teknologisk udvikling, rådgivning og videnudveksling om udnyttelse af geotermisk energi. Et af disse, Jardboranir hf., har specialiseret sig i geotermiske efterforskning og boring, og er nu verdens største selskab på området. ${ }^{149}$ En anden virksomhed bland de tre største, ISOR (Iceland Geosurvey), arbejder med energiforskning og den tredje, Mannvit, er en konsulentvirksomhed, faktisk for både geotermisk energi og andre fagområder.

Nogle af virksomhederne, især blandt de mindste, er stadig under udvikling og mangler at starte en egentlig produktion. I disse arbejder man så med forskning og teknologisk udvikling, til en vis grad for tilskud fra offentlige midler, men nogle virksomheder er baseret næsten udelukkende på ejernes pionerånd og økonomiske egenformåen.

Det kan være nogenlunde let at overskue antallet af virksomheder i Island på området for miljøteknologi, men der bør generelt være en mere systematisk tilgang til opsamling af viden på området. Kun herved kan man på sigt få bedre viden om, hvad der sker i sektoren.

\subsubsection{Eksport af islandsk miljøteknologi}

Relativt simpelt skal her gives en vurdering af eksporten fra sektoren miljøteknologi i Island. Dette ses bedst i relation til Islands samlede eksport og økonomi.

Der foreligger ingen officiel undersøgelse af eksport af islandsk miljøteknologi. Der ingen tal om miljøeknologi i statistiken om produktion og handel fra Islands Statistik, og hidtil har heller ingen anden undersøgt aktiviteterne i denne sammenhæng. I 2010 udgjorde eksporten fra Island i alt ca. 26 milliarder DKK. ${ }^{150}$

Ved at anvende samme fremgangsmåde, som det var tilfældet $\mathrm{i}$ vurderingen af den samlede omsætning af islandske miljøteknologiske virksomheder, kan man skønne deres samlede eksport til ca. 325 millioner DKK for året 2010. Herved regnes knapt halvdelen af den anslåede omsætning til eksport. Dette er dog meget usikkert. Der er en del tegn på, at andelen af eksport i virksomhedernes omsætning stadig vil stige. Ingen undersøgelse er blevet gennemført herom, men

\footnotetext{
149 Jardboranirs hjemmeside www.jardboranir.is

$150 \mathrm{http}: / /$ www.hagstofa.is/Hagtolur/Utanrikisverslun, Islands Statistik, 2011.
} 
synspunktet fremkommer også i en ny rapport om den islandske geotermiske klynge. ${ }^{151}$

I den geotermiske sektor ser det ud til, at den største succes er opnået inden for eksport af viden, f.eks. i de tilfælde, hvor islandske virksomheder beskæftiger sig med koordinering og styring af geotermiske projekter. Desuden har de islandske virksomheders projekter på dette område i udlandet vist sig mere effektive, hvis samarbejdspartnere i det respektive land er intensivt involverede. Det er endvidere næsten sikkert, at der ligger store muligheder for eksport via den undervisning som islandske eksperter kan tilbyde på FN's Geotermiske Universitet, som er beliggende på Island.

\subsection{Vurderinger og initiativer for miljøteknologi i Island}

Dette afsnit forsøger, efter en kort introduktion til centrale aktører i Island, at give et overblik over hvad der er sket i Island vedr. miljøteknologi i perioden. Dermed er der tale om en kronologisk gennemgang af aktiviteter baseret på de tilgængelige rapporter.

\section{Centrale aktører i Island på statsligt plan}

Industriministeriet beskæftiger sig med erhvervslivet i Island, bortset fra fiskeri og landbrug. Industriministeriet er derfor i sidste ende ansvarlig for hovedparten af spørgsmålene i forbindelse med miljøteknologi, selv om andre ministerier naturligtvis også er involveret, såsom Miljøministeriet og Fiskeri- og landbrugsministeriet. Industriministeriet har bl.a. ansvar for spørgsmål vedrørende erhvervslivets udvikling og innovation, herunder:

- Serviceydelser til innovatorer og nystartede og innovative virksomheder

- Teknologisk forskning og udvikling

- Drift af centre for innovatorer

- Finansiering af innovative projekter

- Incitamenter til nye investeringer og udarbejdelse af investeringskontrakter

- Offentlige investeringer i nystartede og innovative virksomheder

\footnotetext{
151 Hákon Gunnarsson og Póra Margrét Porgeirsdóttir (2011): Virðisauki í jarðvarma. Íslenski jarðvarmaklasinn; Vegferð og vegvísir. (På islandsk). (Merværdi i geotermisk varme. Den islandske geotermiske klynge; Rejse og vejviser). 2. udg., Gekon, september 2011.

http://www.gekon.is/images/stories/Vegferd\%20og\%20vegvisir.\%202nd\%20september\%202011.pdf
} 
Ministeriets rolle inkluderer alle aspekter af industrien, herunder ekodesign af produkter, der bruger energi. Ministeriet er også i sidste ende ansvarlig for mineralske ressourcer, herunder forundersøgelse, efterforskning og udnyttelse af ressourcer i undergrunden og på, i eller under havbunden, samt energi, både vedrørende forskning af energikilder og styring af elmarkedet og energivirksomhedernes aktiviteter. ${ }^{152}$

Tre af ministeriets styrelser har nøgleroller i tilskudssystemet til miljøteknologi i Island. Dette er Islands Innovation Center, New Business Venture Fund og Energistyrelsen. Her gives en kort redegørelse for disse institutioners rolle, samt de institutioner og fonde, der er omfattet af disse.

Islands Innovation Center (Nýsköpunarmiðstöð Íslands) fremmer innovation og realisering af nye ideer i den islandske økonomi. Miljø- og energiteknologi er et af organisations otte hovedtemaer. Arbejdet på dette område består primært af undervisning, workshops og rådgivning. ${ }^{153}$ Organisationens støtte til innovation sker bl.a. via IMPRA, der servicerer innovatorer og små virksomheder $\mathrm{i}$ at udvikle ideer og tage de første skridt samt via Islandsk teknologiforskning, som arbejder for at udvikle og overføre innovative teknologier til industrien.

IMPRA er et center for information og vejledning til innovatorer og mindre virksomheder. ${ }^{154}$ Her får man på et enkelt sted bistand til at udvikle forretningsideer og information om drift af virksomheder. Miljøteknologi er meget synligt i IMPRA's arbejde, selvom det ikke er identificeret som et prioriteret område.

Forskningen i teknologi afspejler naturligt nok industriens behov for service, forskning og udvikling, bl.a. vedr. material- og miljøteknologi. Dette omfatter blandt andet rådgivning, som bidrager til en bedre udvælgelse af materialeteknologi, avancerede produktionsforhold, forskning og udvikling relateret til byggebranchen, samt forskning relateret til miljøvenlige løsninger. Det sidstnævnte område får stigende opmærksomhed, herunder energieffektivitet, miljøvenlige brændstoffer og miljøvenlige fangstredskaber. ${ }^{155}$

New Business Venture Fund (Nýsköpunarsjóður atvinnulifsins) arbejder med venture kapital og investerer i innovative start-ups, hvor der forventes en stor værdiskabning og rentabilitet. Fonden har ikke specialiseret sig i bestemte brancher, men har dog defineret flere kategorier af investeringer, herunder miljøteknologi. Fonden er drevet på grundlag af sine indtægter og modtager ingen støtte fra staten, ud over startkapital som den islandske regering tilvejebragte i begyndelsen. Fondens overskud er øremærket til fremtidige investeringer i

\footnotetext{
152 Industriministeriet Island (2011) www.idnadarraduneyti.is

153 Innovation Center Island (2011). Miljø- og energiteknologi http://nmi.is/umhverfis--og-orkutaekni

154 IMPRA. http://www.nmi.is/impra

155 Innovation Center Island (2011). http://www.nmi.is
} 
virksomheder, og fonden kan investere direkte i virksomheder ved at købe aktier eller indirekte ved at deltage i andre fonde, der investerer i innovative virksomheder. ${ }^{156}$

Energistyrelsen (Orkustofnun) (NEA) er ansvarlig for administration af energi- og ressourcemæssige opgaver, d.v.s. spørgsmål i forbindelse med geotermi og vandkraft, kulbrinte (olie og gas), metaller og andre mineralske materialer. NEA vurderer mulighederne for nye energikilder og arbejder for en udvikling mod mere miljørigtige energiformer, samt på formidling af viden om anvendelse af miljøvenlige løsninger på energiområdet. Styrelsen er også vært for det islandske udvalg for Energi-forudsigelse (Orkuspárnefnd), hvilket er et samarbejdsforum for Islands Statistik, Landregistret, Finansministeriet og nogle af de viktigste virksomheder, institutioner og organisationer inden for energisektoren $\mathrm{i}$ landet. Udvalget har fungeret siden 1976 og har bl.a. rollen at sammenfatte de generelle antagelser, som forudsigelserne baseres på. I forbindelse med dette arbejder NEA stadigt med langsigtig planlægning omkring Islands energi, såvel som den varetager udstedelse af licenser til efterforskning og udnyttelse af ressourcer og energi. I NEA findes megen information, der kan bruges i innovative projekter, herunder i udviklingsprojekter inden for miljøteknologi. ${ }^{157}$

I tillæg til det ovennævnte har Industriministeriet også ansvar for Teknologiudviklingsfonden (Tæknipróunarsjóður), hvilket er en særlig vigtig del af det offentlige støttesystem. Forskningscentret Rannís forvalter fonden efter kontrakt med ministeriet, men Rannís tilhører ellers Ministeriet for Uddannelse og Kultur. Yderligere information om Teknologiudviklingsfonden findes nedenfor.

Hertil kommer også Islandsstofa, som også tilhører det offentlige støttesystem. Íslandsstofa har til formål at skabe et godt image for Island og dermed at støtte islandske industrier på udenlandske markeder, samtidigt med at udenlandske turister og investeringer tiltrækkes til landet. I de senere år har Islandsstofa i samarbejde med Islands Industriforbund (SI) deltaget i et nordisk projekt med titlen Nordic Clean Tech Alliance. Inden for dette projekt arbejder Islandsstofa med virksomheder, som markedsfører miljøteknologier i udlandet og fremmer netværk med partnere i Norden. Íslandsstofa har udtrykt interesse $\mathrm{i}$ at arbejde mere på dette område, men til dato har miljøteknologi ikke været et af de prioriterede områder i institutionens internationale markedsarbejde.

I Island drives også FN's Geotermiske Universitet, hvor islandske eksperter inden for det geotermiske område formidler viden. Hermed er der blevet udarbejdet en række kontrakter for udvikling og bistand på

156 New Business Venture Fund (2011). http://www.nsa.is

157 Orkustofnun (2011). http://www.os.is 
dette område. For eksempel blev der i november 2011 indgået en kontrakt mellem industriministeren og regeringen i Rwanda om landenes samarbejde omkring geotermisk energi. Islandske virksomheder har allerede deltaget i flere geotermiske projekter i Rwanda, og studerende derfra har studeret ved FN's Geotermiske Universitet. ${ }^{158}$

Af indlysende grunde spiller Miljøministeriet en rolle i forbindelse med fremme af miljøteknologi i Island. Der arbejder man dog ikke direkte på projekter på dette felt, og ministeriet har hverken formuleret en politik for miljøteknologi eller har midler til at gå ind på området. Således har islandske myndigheder undladt at involvere sig i arbejdet omkring ETAP.

Innovit er endvidere en enhed, der har betydning for udviklingen af virksomheder inden for miljøteknologi. Innovit er et center for innovation og innovatorer, der fremmer aktiviteter gennem arrangementer, rådgivning og service. Centret blev grundlagt af universitetsstuderende i 2007 og er et privatejet iværksætteri, drevet i samfundets interesse med støtte af forskellige parter, herunder Industriforbundet (SI). ${ }^{159}$

\subsubsection{Rapporter og beslutninger}

Som meget sigende for Island var der i forbindelse med en workshop om nordisk miljøteknologi i marts 2006 en vurdering af miljøteknologi i Island. ${ }^{160}$ Her blev det vurderet, at Island ikke havde en strategi for miljøteknologi, og at man kun inden for energiområdet kunne siges at have miljøteknologiske interesser i Island i 2006. Miljøteknologi havde på dette tidspunkt ikke fået nogen synderlig opmærksomhed på Island. Island havde valgt at undlade at deltage i ETAP-processen i EU og synes ikke at have vist interesse for denne proces, samt den internationale udvikling af miljøteknologi.

Islandske myndigheder har følgelig undladt at formulere en egentlig politik for miljøteknologi, eller for tilskud/støtte for projekter inden for området. Således er miljøteknologi ikke nævnt ved navn i Islands strategi for bæredygtig udvikling, hverken den langsigtede strategi, som

\footnotetext{
158 Industriministeriet Island (2011). Samstarfssamningur við Rúanda um jarðhita. (På islandsk). (Samarbejde med Rwanda omkring geotermisk varme). Pressemeddelelse 24. november 2011. http://www.idnadarraduneyti.is/frettir/frettatilkynningar/nr/3349).

159 Innovit (2011). www.innovit.is.

160 Nordisk Innovationscenter: Workshop on Nordic Environmental Technology - Innovation and Export, Oslo, Norway, March 29-30, 2006, 21 sider.
} 
blev vedtaget i 2002 og er gyldig indtil 2020, ${ }^{161}$ eller i den gældende 4års strategi for perioden 2010-2013. ${ }^{162}$

Miljøteknologi er dog indirekte involveret i disse dokumenter i diskussionen om energi og affald. Af den langsigtede strategi fremgår blandt andet, at det er vigtigt at "fremme øget viden og teknologiske fremskridt i udnyttelsen af landets vedvarende energikilder". Ifølge strategien bør man også have fokus på „fremskridt og forskning i nye energikilder og energibærere“ og fremme „effektivisering af energiproduktionen gennem øget viden om landets energiressourcer og forbedret teknologi til produktion af energi." Disse indsatsområder er afspejlet i den fire-årige strategi, hvor der findes en passus om undersøgelse af mulighederne for at „installere varmepumper til rumopvarmning i områder, hvor det skønnes lønsomt", dersom det er blevet påvist, at "varmepumper kan være et godt alternativ og spare betydelige mængder energi i områder, der bruger el til opvarmning“. Der skal også arbejdes med en bedre energieffektivitet, herunder med forbedret teknologi, med fokus på en yderligere udnyttelse af den store mængde energi, der går til spilde i højtemperaturområder, som er blevet anvendt til el-produktion.

\section{Parlamentets rapport om grøn økonomi}

Det mest bemærkelsesværdige, der er sket i Island om miljøteknologi, er Parlamentets arbejde med grøn økonomi. Dette arbejde blev påbegyndt i 2009 med et forslag til en parlamentsbeslutning om grøn økonomi. ${ }^{163}$ Selve parlamentsbeslutningen er fra juni 2010. Heri beskrives rimelig detaljeret om den opgave om grøn økonomi, hvor parlamentet nedsætter en arbejdsgruppe til at udarbejde en rapport.

Selve rapporten, der kan oversættes til: Fremme af grøn økonomi i island, blev offentliggjort i september 2011. Den fremstår med sine 63 tætskrevne sider, som et virkelig godt bud på, hvad Island skal gøre for at fremme grøn økonomi, inkl. miljøteknologi. ${ }^{164}$

Grøn økonomi beskrives på en virkelig dygtig måde i en international sammenhæng. Reguleringer og andre styringsmidler som tilskud, fremme af teknologi, etc. beskrives i detaljer. Efter hvert afsnit anføres

\footnotetext{
161 Miljøministeriet Island (2002): Velferð til framtíðar. Sjálfbær próun í íslensku samfélagi - Stefnumörkun til 2020. (På islandsk). (Velfærd for fremtiden - Bæredygtig udvikling i det islandske samfund - Strategi til 2020). Miljøministeriet, Reykjavík.

http://www.umhverfisraduneyti.is/media/PDF_skrar/Velferd_til_framtidar_2002.pdf.

162 Miljøministeriet Island (2010): Velferð til framtíðar. Sjálfbær próun í íslensku samfélagi - Áherslur 20102013. (På islandsk). (Velfærd for fremtiden - Bæredygtig udvikling i det islandske samfund - Fokusområder 2010-2013). Miljøministeriet, Reykjavík. http://www.umhverfisraduneyti.is/media/PDF_skrar/Velferd-tilframtidar-2010-2013.pdf.

163 138. Löggjafarthing 2009-2010. Tillaga til thingsályktunar, 6 sider.

164 Det Islandske parlaments udvalg for fremme af grøn økonomi (2011). Efling græns hagkerfis á Íslandi. Sjálfbær hagsæld -samfélag til fyrirmyndar. (På islandsk). (Fremme af grøn økonomi i Island. Bæredygtig velstand - et samfund som forbillede). http://www.althingi.is/pdf/Graent_hagkerfi.pdf.
} 
rekommendationer, som igen føres frem i indledningen til ikke mindre end 48 anbefalinger. Dette må vurderes til at være ganske meget, men kan også ses som et udtryk for en omhyggelig og meget detaljeret tilgang.

Man kan nævne flere af anbefalingerne:

- Statsminister og statsministeriet skal styre området

- Der skal skabes et tilstrækkeligt statistisk grundlag for grøn økonomi

- Ministerier og offentlige institutioner skal påtage sig en række nye opgaver for at fremme grøn økonomi, som f.eks. grønne indkøb og udbud

- Den teknologiske udviklingsfond skal etablere en grøn fond, som finansierer miljøteknologi

- New Business Venture Fund skal etablere en særlig grøn investeringsfacilitet

- Der skal etableres uddannelsesprogrammer om grøn økonomi

- Forskellig regulering skal analyseres og evt. styrkes

- Der skal tages en række energipolitiske initiativer

Dette var blot ganske få af de mange anbefalinger. Der er tilmed sat aktørnavn på hver af de 48 anbefalinger, hvilket er meget positivt, idet man så ikke behøver at drøfte, hvem der nu skal gøre en ekstra indsats.

Status på rapporten er (december 2011), at den er under behandling for at kunne blive endelig vedtaget i regeringen.

Generelt må man vurdere, at den islandske rapport om grøn økonomi er meget værdifuld, naturligvis for udviklingen i Island, men også som et bidrag til en nordisk fællesdrøftelse, hvor der endnu ikke er kommet mange sådanne gode rapporter om grøn økonomi frem. Selvom miljøteknologi ikke har en meget fremtrædende plads i rapporten, er temaet nævnt flere steder, og der er gode anbefalinger til at styrke området. Det kan bemærkes, at Parlamentet har besluttet, at rapporten skal oversættes til engelsk. Herved kan den promoveres internationalt. Og det vil være en stor fordel for Island, hvis regeringen snart vedtager alle anbefalingerne.

Tilsvarende vægt på miljøteknologi findes i udkastet til energipolitik for Island, som arbejdsgruppen for energipolitikken forelagde for industriministeren i november 2011. ${ }^{165}$

Clean Tech Iceland har endvidere udarbejdet et udkast til rapport om status og perspektiver for miljøteknologi i Island, men denne rapport er endnu ikke blevet endelig offentliggjort. ${ }^{166}$ Desuden har den nystiftede geotermiske klynge udgivet en rapport om mulighederne på området,

\footnotetext{
165 Energipolicyudvalget (2011). http://www.nea.is/orkustefnun efnd.

166 Clean Tech Iceland (2011). Clean Tech Iceland: A Vision for Success. Draft, February 2011.
} 
men denne omfatter naturligvis kun det geotermiske område, omend det er så centralt for udviklingen i Island. ${ }^{167}$

\section{Den grønne energi - fremme af vedvarende energi i transportsekktoren}

I maj 2010 udnævnte industriministeren en projektstyrelse for et særligt projekt om udvikling af energi i transportsektoren. Projektet fik overskriften Den grønne energi - økoenergi. Dette er i virkeligheden et klyngesamarbejde om fremme af vedvarende energi i transportsektoren. Det har til formål at øge andelen af miljørigtige indenlandske energikilder i transportsektoren på bekostning af importerede fossile brændsler. Industriministeren har taget initiativ til projektet $\mathrm{i}$ samarbejde med andre ministerier, styrelser og kommuner. ${ }^{168}$ Projektet omfatter en detaljeret analyse, som blev afsluttet i efteråret 2011. Efterfølgende afleverede projektstyrelsen den udarbejdede rapport til ministeren den 22. november 2011. ${ }^{169}$ Rapporten indeholder en handlingsplan om ændring af energiformerne i transportsektoren på land. Ligeledes kommer den ind på muligheden for ændringer i energiformerne for søtransport, idet køretøjer og skibe samlet bruger omkring $60 \%$ af alle fossile brændstoffer i Island. ${ }^{170}$

I rapporten om Den grønne energi er der i alt 26 anbefalinger til handling. De fleste af disse foreslås gennemført i løbet af år 2012. Gennemførelsen af mange af forslagene vil meget sandsynligt styrke miljøteknologien, men først må der gennemføres en række forbedringer af de lovgivningsmæssige rammer. Forslagene er på mange måder identiske med forslag i rapporten fra Parlamentets udvalg for fremme af grøn økonomi, men er naturligt mere specifikke, dersom de drejer sig om et bestemt område snarere end om økonomien som helhed.

\footnotetext{
167 Hákon Gunnarsson og Póra Margrét Porgeirsdóttir (2011): Virðisauki í jarðvarma. Íslenski jarðvarmaklasinn; Vegferð og vegvísir. (På islandsk). (Merværdi i geotermisk varme. Den islandske geotermiske klynge; Rejse og vejviser). 2. udg., Gekon, september 2011. http://www.gekon.is/images/stories/Vegferd\%20og\%20vegvisir. \%202nd\%20september\%202011.pdf

168 Industriministeriet Island (2010). Græna orkan. Vistorka í samgöngum. (På islandsk). (Den grønne energi økoenergi i transport). http://www.idnadarraduneyti.is/graena-orkan.

169 Industriministeriet Island (2011). Svona náum við markmiðunum! Verkefnisstjórn Grænu orkunnar afhendir iðnaðarráðherra skýrslu um orkuskipti í samgöngum. (På islandsk). (Sådan når vi målene! Projektstyrelsen for Den grønne energi afgiver sin rapport til ministeren). Nyhed på hjemmeside 22. nóv. 2011. http://www. idnadarraduneyti.is/frettir/frettatilkynningar/nr/3343.

170 Den grønne energi - økoenergi i transport (2011). Orkuskipti í samgöngum. Stefnumótun, markmiðasetning og aðgerðaáætlun. (På islandsk). (Udveksling af energi i transport. Policy, målsætning og handlingsplan). http:// graenaorkan.is.w7.nethonnun.is/wp-content/uploads/2011/10/Sk\%C3\%BDrsla-Gr\%C3\%A6nu-orkunnar22.11.2011.pdf.
} 


\subsection{Tilskud fra den islandske regerings side}

Den islandske regering har ikke oprettet nogen egentlig mekanisme til at støtte virksomheder, som arbejder med miljøteknologi. Regeringen yder dog årligt en betydelig mængde tilskud til innovative projekter, hvor projekter inden for miljøteknologiområdet kan betragtes på lige fod med andre områder. I tillæg til dette forvalter Industriministeriet på vegne af staten en såkaldt Energifond (Orkusjóður), som giver tilskud og lån til innovation og forbedring $\mathrm{i}$ energisektoren. Fondens kapital går formentlig $\mathrm{i}$ en stor grad til projekter inden for miljøteknologi, uden at det er udtrykkeligt nævnt i reglerne for fonden. Men dette drejer sig om ubetydelige midler. Endelig har Islands Innovation Center flere mindre fonde til støtte for produktudvikling og innovation af forskellige slags. Her er miljøteknologi dog heller ikke defineret som en særskilt prioritet. Bidrag fra disse fonde er typisk mindre end 150.000 DKK i hvert tilfælde. ${ }^{171}$

De følgende afsnit giver oplysninger om finansiering af innovative projekter og Energifondens rolle.

\section{Støtte til innovation}

I Island har de miljøteknologiske virksomheder ikke adgang til nogen særlig støtte eller midler, udover det som gælder for innovative virksomheder i almindelighed. Offentlig støtte til innovation, er imidlertid betydelig, både gennem Teknologiudviklingsfonden og i overensstemmelse med loven om støtte til innovation i erhvervslivet, nr. 152/2009. Regionale vækstaftaler er også vigtige i denne sammenhæng. Virksomheder inden for miljøteknologi har de samme muligheder som andre virksomheder til at modtage midler gennem disse kanaler, så længe aktiviteten definieres som innovation.

Teknologiudviklingsfonden (Tæknibróunarsjóður) har fungeret siden 2004, da fonden erstattede den tidligere Teknologifond (Tæknisjóður), som havde været i drift siden 1994. Fonden er designet til at støtte F\&U inden for teknologisk udvikling med henblik på innovation i den islandske økonomi. Til dette formål kan fonden finansiere innovative projekter i overensstemmelse med Videnskabs- og teknologirådets principper. ${ }^{172}$ Fonden yder tre typer af tilskud:

\footnotetext{
${ }^{171}$ Innovation Center Island (2011). Tilskud og støtteprojekter. http://www.nmi.is/impra/styrkir-ogstudningsverkefni.

172 Rannís (2011). Teknologiudviklingsfonden. http://www.rannis.is/sjodir/taeknithrounarsjodur/yfirlit-styrkja.
} 


\section{- 1. Projektbevillinger}

Generelle tilskud ydes for op til 3 år og kan blive op til 450.000 DKK pr. projekt og år. Et krav stilles til 50 \% egenfinansiering fra ansøgerne. Denne kategori (dvs. nye tilskud og fortsatte tilskud) fylder omkring 2/3 af Teknologiudviklingsfondens årlige budget

- 2. Pionértilskud

Pionértilskud er skræddersyet til at imødekomme det behov, som findes hos nystartede virksomheder og iværksættere med projekter i en startfase. Disse tilskud ydes til pionérer, der har etableret eller planlægger at etablere en virksomhed på deres idégrundlag. Det antages at $\mathrm{k} ø \mathrm{~b}$ af tjenesteydelser fra forskningsinstitutter og universiteter er mindre end $20 \%$ af bidraget. Projekter der modtager pionértilskud skal have en stor nyskabningsværdi, i de fleste tilfælde er forskning en væsentlig del af projekterne, men omsætning og værdi er sædvanligvis vanskelig at definere. Ansøgerne må fremlægge en forretningsplan, hvor den planlagte omsætning og indenlandske værdiskabning fremgår. Pionértilskud ydes i højst 2 år og kan beløbe sig til 230.000 DKK om året. Et krav stilles til 25 \% egenfinansiering fra ansøgerne

- 3. Brotilskud, infrastruktur og markedsføring

Brotilskud er skræddersyet til det behov, som findes hos virksomheder, der er blevet etableret og har en årlig omsætning på under 14 mio. DKK. Virksomheder kan søge midler til infrastruktur, d.v.s. drift i form af software o.s.v., samt til markedsføring, der normalt er forbundet med tidligere produktudvikling relateret til F\&U for de samme produkter. Tilskud gives generelt ikke til investeringer i udstyr. Projekter i denne kategori har en lav nyskabningsværdi, men sædvanligvis foreligger information om omsætning og/eller produktets værdi. Ansøgeren må fremlægge en detaljeret forretningsplan med et velbegrundet bud på omsætning. I tilfælde af tjenesteprojekter, kræves der en redegørelse om nationaløkonomisk betydning. Projekterne er kun finansieret i et år til et maksimum på 230.000 DKK. Et krav stilles til $50 \%$ egenfinansiering fra ansøgerne

Et fagligt udvalg vurderer ansøgninger til Teknologiudviklingsfonden ud fra nyskabning (N), økonomisk værdi (V), andre værdier (G) og sandsynligheden for succes (L). De forskellige parametrer gives forskellige vægtningsfaktorer (se i tabellen nedenfor).

\begin{tabular}{lccc}
\hline Typer af tilskud & Nyskabning (N) & Økonomisk værdi (V) & Andre værdier (G) \\
\hline Projektbevilling & $30 \%$ & $40 \%$ & $30 \%$ \\
Pioneretilskud & $50 \%$ & $25 \%$ & $25 \%$ \\
Brotilskud & $20 \%$ & $50 \%$ & $30 \%$ \\
\hline
\end{tabular}


En samlet bedømmelse for hvert projekt findes gennem at multiplicere bedømmelsen for enkelte parametrer $(\mathrm{N}, \mathrm{V}$ og $\mathrm{G})$ med respektive vægtningsfaktorer fra tabellen. Sandsynligheden for succes regnes siden til en forhøjelse på en sådan måde, at resultatet fra den oprindelige beregning multipliceres med $1+\mathrm{L}$, f.eks. 1,00 hvis sandsynlighed for succes er ingen, men 2,00 hvis sandsynligheden for succes er $100 \%$. Hvis sandsynligheden ligger under et vist niveau regnes projektet ikke at opfylde betingelserne. Tilsvarende må projekter opnå et vist minimum for hver af de tre vurderingskriterier, d.v.s. for nyskabning, økonomisk værdi og andre værdier. ${ }^{173}$

Teknologiudviklingsfonden betjener et bredt spektrum af virksomheder, herunder virksomheder inden for medicinsk teknologi, computerspil o.s.v. Miljøteknologi har derimod ikke været en specifik prioritering hos fonden. Som det fremgår af ovenstående tabel, er miljøaspekter heller ikke blandt de emner, der lægges til grund for beslutninger om bevillinger. I teorien kunne miljøaspekter egentlig indgå i „Andre værdier“, men det afspejles ikke i fondens regler og retningslinjer. ${ }^{174}$

Teknologiudviklingsfonden er finansieret med årlige statslige bidrag, der beløber sig til 30-35 millioner DKK om året i de seneste år. Bidraget var således 28 mio. i 2008, 32 mio. i 2009, 33 mio. i 2010 og 33 mio. i 2011. Budgetforslaget for 2012 lyder på 34 mio. DKK. ${ }^{175}$ Bidrag til fonden er hverken steget i takt med inflation eller efterspørgsel. Således modtog fonden 91 ansøgninger i 2008 men 266 ansøgninger i 2009. Bidrag til fonden blev hævet $15 \%$ mellem disse år, men på samme tid steg priserne med $21 \% .{ }^{176}$ Hvis bidraget bliver på 34 mio. DKK i 2012, som forudset i budgetforslaget svarer det til en stigning på $20 \%$ i nominelle termer siden 2008, men samtidig er priserne steget med omkring $60 \%$. Her spiller det økonomiske sammenbrud i efteråret 2008 den største rolle, da priserne steg markant samtidigt med, at staten mistede en betydelig del af sine indtægter.

Loven om støtte til innovation i erhvervslivet, $n r$. 152/2009 giver de innovationsvirksomheder, som beskæftiger sig med godkendte forskningseller udviklingsprojekter mulighed for et skattefradrag på $20 \%$ af aktuelle udgifter til sådanne projekter, op til en vis grænse $(20 \%$ af 4,5 millioner DKK om året pr. virksomhed). De beløb, der ikke kommer til nytte som

\footnotetext{
173 Rannís (2011). Teknologiudviklingsfonden. http://www.rannis.is/sjodir/taeknithrounarsjodur/ umsokn-og-upplysingar/umsoknargogn

${ }^{174}$ Rannís (2011). Teknologiudviklingsfonden. http://www.rannis.is/sjodir/taeknithrounarsjodur/ umsokn-og-upplysingar/leidbeiningar-taeknithrounarsjodur.

175 Fjárlagavefurinn (2011). http://www.fjarlog.is.

${ }^{176}$ Hagstofa Íslands. Breytingar á samræmdri vísitölu ney sluverðs frá 2005. (Ændringer i det harmoniserede forbrugerprisindeks (HICP) siden 2005). http://www.hagstofa.is/Hagtolur/Verdlag-og-ney sla/Samraemdvisitala-neysluverds.
} 
skattefradrag betales direkte til virksomheden. Loven gælder for perioden 2010-2014, og målet er at fremme forskning og udvikling og at forbedre innovationsvirksomhedernes konkurrencevilkår. Bidrag til enkelte selskaber besluttes samtidigt med, at skatten vurderes for det forudgående regnskabsår. ${ }^{177}$

År 2010 var det første driftsår i funktionsperioden for lov nr. $152 / 2009$. Dermed kunne man se de første oplysninger om godkendte beløb i efteråret 2011 i kobling til afgørelse om skatter for 2010. I alt var 53 enheder berettiget efter loven til refundering af udgifter til innovation i 2010, i alt på 23 mio. DKK. ${ }^{178}$ De samlede direkte statslige bevillinger til forskning, udvikling og innovation i erhvervslivet er således omkring 56 mio. DKK i 2011. Deraf kommer 33 mio. via Teknologiudviklingsfonden og 23 mio. som konsekvens af lov $\mathrm{nr}$. $152 / 2009$. Ingen af disse bidrag er specifikt øremærket miljøteknologi.

Vækstaftaler er særlige aftaler om innovation og erhvervsudvikling mellem Industriministeriet og regionale erhvervs- og udviklingsforeninger. Prioriteringerne er fastlagt på grundlag af lokale prioriteringer, og regionale aktører er ansvarlige for gennemførelsen af aftalen og styring af resultaterne. Formålet er blandt andet at styrke lokale klynger af virksomheder, som er baseret på unikke egenskaber og muligheder i de respektive områder. Særlig vægt lægges på joint ventures, support systemer og universitetsforskning. Virksomheder inden for miljøteknologi kan søge om støtte fra vækstaftalerne for bestemte projekter, men de prioriteres ikke over andre projekter.

\section{Energifonden (Orkusjóður)}

Energifonden (Orkusjóður) opererer efter loven om Energistyrelsen (NEA) nr. 87/2003 og forordning om Energifonden nr. 514/2003. Fonden er statens ejendom og får indtægter delvis fra stadsbudgettet og delvis gennem renter. Tilsyn med fonden ligger hos industriministeren, men NEA har ansvaret for den daglige ledelse og forvaltning. Et specielt Energiråd fremlægger forslag til ministeren om lån og betalinger fra fonden. ${ }^{179}$

Energifondens rolle i henhold til forordningen er at "fremme en effektiv udnyttelse af energiressourcerne gennem tilskud eller lån,

\footnotetext{
177 Alpingi (2009). Lög nr. 152/2009 um stuðning við nýsköpunarfyrirtæki. (Lov om støtte til innovation i erhvervslivet). http://www.althingi.is/lagas/nuna/2009152.html.

178 Fjármálaráðuneytið (2011). Nýsköpun í atvinnumálum - grein ráðherra 10. nóv. 2011. (Innovation i erhvervslivet - ministerens artikel 10. nov. 2011). http://www.fjarmalaraduneyti.is/radherra/ raedur_og_greinar/nr/14783. ${ }^{179}$ Alpingi (2003). Lög nr. 87/2003 um Orkustofnun. (Lov om NEA). http://www.althingi.is/lagas/128b/ 2003087.html, og Reglugerð.is (2003). Reglugerð um Orkusjóð nr. 514/2003. (Forordning om Energifonden). http://www.reglugerd.is/interpro/dkm/WebGuard.nsf/58b439f05a7f412f00256a07003476bc/20118d9a9 8da225a00256d5f004284db?Open Document.
} 
herunder navnlig foranstaltninger med henblik på at reducere brugen af fossile brændstoffer." Dette bør ske ved at yde:

- lån for at søge efter geotermisk varme, som vurderes at være $ø$ konomisk fordelagtig til at reducere samfundets omkostninger ved opvarmning af boliger

- tilskud eller risikolån til design og konstruktion af prototyper af udstyr og systemer til forskning og anvendelse af energiressourcerne

- tilskud til særlige projekter vedrørende økonomisk energiforbrug, herunder til uddannelse og informationsaktiviteter

- tilskud til projekter, som fremmer udnyttelsen af indenlandsk energi i stedet for fossile brændstoffer og som styrker det internationale samarbejde om sådanne projekter

Formentlig går en stor del af kapitalen under punkt 2 og 4 ovenfor til virksomheder og projekter inden for miljøteknologi. Men den finansielle ramme for fonden er meget smal. Således modtog fonden fra statsbudgettet i 2011 kun et beløb, som svarer til 1,4 mio. DKK, og den skønnede indkomst fra renter var omkring 0,6 mio. Tilsvarende beløb kan udlæses af budgettet for mange tidligere år. Det årlige budget for fonden er således noget omkring 2 mio. DKK.

\section{Fremtidige planer}

I rapporten fra Parlamentets udvalg om fremme af grøn økonomi, som blev udsendt i efteråret 2011, foreslås at der oprettes en Grøn konkurrencefond som en afdeling i Teknologiudviklingsfonden og som kun finansierer projekter inden for miljøinnovation. Faciliteten foreslås at være analog til Teknologiudviklingsfondens aktuelle finansieringsstrategi, hvor der kræves $50 \%$ egenfinansering. Et udvalg af eksperter skal vurdere ansøgningerne og fremsætte forslag til tilskud i overensstemmelse med definitioner fra De Forenede Nationer og det amerikanske Bureau of Labor Statistics (BLS) for grønne jobs og grøn økonomi. En idé er, at fonden kan finansieres gennem en forhøjet karbonafgift på brændstof samt en del af de foreslåede forureningsafgifter. Rapporten indeholder også et forslag om, at den grønne $\varnothing$ konomis prioriteringer skal flettes ind i vækstaftalerne.

Forslagene fra udvalget om fremme af grøn økonomi drøftes i parlamentet i december 2011, og det er for tidligt at forudsige hvilke forslag, som bliver til virkelighed. Derudover foreligger der ingen informationer om regeringens planer om særlig støtte for at fremme miljøteknologi i det islandske erhvervsliv. 


\subsection{Islandske eksempler med international succes}

\section{Clean Tech Iceland}

I sommeren 2010 blev der oprettet en sektorgruppe, Clean Tech Iceland, for virksomheder i miljøteknologi inden for det islandske industriforbund (SI). Til gruppen hører nu 14 virksomheder. ${ }^{180}$ Gruppen er grundlagt til at accelerere virksomheders vækst, herunder ved at fremme eksport, finansiering af projekter, uddannelse af personalet, gunstige lovrammer og bæredygtig planlægning og arealanvendelse. De vigtigste prioriteringer ${ }^{181}$ inden for gruppens arbejde er:

- Vedvarende energi (renewable energy)

- Energieffektivitet (energy efficiency)

- Energi management (energy management)

- Affaldshåndtering (waste management)

Clean Tech Iceland er en kombination af etablerede og nye virksomheder, d.v.s. virksomheder som allerede har etableret sig på markedet, og andre som stadigvæk er i opstarts- eller udviklingsfasen. Flere af virksomhederne har dog nået den kritiske masse til at være med til at danne en stærk gruppe.

Som noget særlig interessant har Clean Tech Iceland fremhævet vigtigheden af at foretage kortlægning og evaluering af miljøteknologi i Island, for at gøre det lettere at forstå, hvor styrkerne ligger, hvilken størrelse sektoren har, og hvad der er virksomhedernes vanskeligste udfordringer. Her gælder det samme som andre steder, at det er vanskeligt at formulere politik og forbedre styringen, hvis tema og problemer ikke er særlig kendte.

\section{Energiteknologi}

Som nævnt ovenfor er det anslået, at omkring 26 ud af 43 virksomheder inden for miljøteknologi i Island arbejder på at udvikle og sælge teknologi i energiproduktionen, herunder 8 der har specialiseret sig $\mathrm{i}$ udnyttelsen af geotermisk energi. Energiteknologi udgør uden tvivl den største del af miljøteknologisektoren i Island, hvilket ikke er overraskende, eftersom Island har rige geotermiske ressourcer, som er blevet udnyttet med succes i årtier. I forbindelse med dette har der udviklet sig virksomheder, der arbejder med teknologier inden for vedvarende energi til transport, og energibesparelser i både transport på sø og land, samt i bygninger. Virksomhederne leverer løsninger, der løser de miljøproblemer man står overfor, samtidigt med, at de opbygger

180 Bryndís Skúladóttir, Islands industriforbund (SI), e-post 29.11.2011.

181 Clean Tech Iceland (2011). Clean Tech Iceland: A Vision for Success. Draft, February 2011. 
industrien og skaber eksport. Det islandske marked er lille, og derfor har de fleste virksomheder andre lande i sigte, da løsningerne er globale og markeden i vækst. I de følgende afsnit bliver der nævnt nogle af virksomhedernes opgaver inden for energiteknologi.

Jarðboranir var oprindeligt et statsligt organ, men blev omdannet til et aktieselskab i 1986 og efterfølgende privatiseret og børsnoteret på aktiemarkedet i tidsrummet efter $1990 .{ }^{182}$ Selskabets omsætning var på vej mod 650 millioner DKK (daværende valutakurs) i den økonomiske bobbletid i 2008. ${ }^{183}$ I begyndelsen af 2011 blev virksomheden til et datterselskab til Islandsbanki som en del i omstrukturering i kølvandet af det økonomiske sammenbrud i 2008. Jarðboranir er nu verdens største boringsvirksomhed, med speciale i geotermisk energi. Selskabet ejer datterselskaber i Tyskland, England, Chile, Azorerne og New Zealand, men har også været involveret i projekter med anvendelse af ressourcer i undergrunden, såsom erhvervelse af varmt vand, damp og drikkevand på Færøerne, Irland, Schweiz, Ungarn og andre steder. Selskabet har på nuværende tidspunkt omkring 120 medarbejdere. Som et eksempel på størrelsen af udenlandske projekter blev i sommeren 2011 indgået en kontrakt for geotermiske boringer i New Zealand til en samlet værdi af 140 millioner DKK. ${ }^{184}$

Íslenskar orkurannsóknir (ÍSOR) (Iceland Geosurvey) blev skabt 2003, ved at energiforskning blev udskilt fra Energistyrelsens administrative opgaver og placeret i en separat enhed med lov nr. 86/2003. Ifølge lovens første paragraf er ÍSOR „en særlig statslig styrelse under Industriministeriet“. ÍSOR's rolle er „at arbejde på projekter og forskning inden for natur-, energi og andre naturressourcer, som bestyrelsen beslutter." Udnyttelse af geotermisk energi er dog ÍSOR's primære speciale. Organisationen har været involveret i geotermisk udvikling i Island, både lav- og høj-temperatur. Organisationen har fået en niche blandt de mest respekterede geovidenskabsinstitutioner i verden og har rådgivet på en lang række opgaver inden for forskning, udvikling og opbygning i geotermiske områder på alle kontinenter undtagen Australien. ÍSOR opererer på et kommercielt grundlag $i$ et konkurrencepræget marked og tjener penge udelukkende ved salg af forskning, rådgivning, service og information, eller andre projekter inden for sit felt. Endvidere kan ÍSOR, med forbehold af ministerens godkendelse, deltage i forsknings- og udviklingsvirksomheder, der er aktieselskaber eller andre enheder med begrænset ansvar. ÍSOR ejer nu

\footnotetext{
182 Jarðboranir (2011). Saga. http://www.jardboranir.is/?PageID=669.

183 Viðskiptablaðið (2007). Innleysir 11 milljarða króna hagnað með sölu Jarðborana. Frétt á heimasíðu 1. ágúst 2007. http://www.vb.is/frett/26073/?q=Jar\%C3\%B0boranir.

184 Jarðboranir (2011). Jarðboranir undirrita nýjan borsamning til tveggja ára á Nýja-Sjálandi. Frétt á heimasíðu 27. júlí 2011. http://www.jardboranir.is/?PageID=13\&NewsID=1558.
} 
datterselskabet GeoThermHydro i Chile. ${ }^{185}$ I praksis fungerer ÍSOR som enhver anden virksomhed. Når vi taler om rammer for og omfanget af miljøteknologi i Island, er det derfor spørgsmålet, om ÍSOR skal betragtes som en offentlig institution eller en virksomhed, der sælger sine produkter og serviceydelser både på hjemmemarkedet og i udlandet og konkurrerer med andre virksomheder. ÍSOR har nu ca. 80 ansatte og er dermed en af de største virksomheder på den islandske miljøteknologiarena.

Flere selskaber har specialiseret sig i rådgivning inden for geotermisk energi med fokus på projekter i udlandet. Disse virksomheder er typiskt dukket op ved samarbejde mellem ingeniørsfirmaer. Et eksempel er Enex, der blev grundlagt i 1969 under navnet Virkir Engineering Group. I dag lægger virksomheden særlig vægt på design, opførelse, drift og finansiering af kraftværker, både geotermiske anlæg og vandkraftværker, samt på udvikling af nye teknologier til geotermisk energi. Virksomhedens projekter har blandt andet været i USA, Kina, Tyskland, Ungarn, El Salvador, Slovakiet og Guadeloupe, i nogle tilfælde i samarbejde med tilknyttede virksomheder. ${ }^{186}$

Mindre virksomheder i den geotermiske sektor har bl.a. beskæftiget sig med udvikling og produktion af specialiserede varmerør, indsamling og komprimering af kuldioxid fra geotermiske anlæg, udvikling af generatorer for geotermiske kraftværker og design af nye teknologier for en forbedret effektivitet i el-produktion fra geotermisk energi.

Et antal andre virksomheder arbejder med at udvikle løsninger inden for energiteknologi. I november 2011 begyndte virksomheden Carbon Recycling International, f.eks. at producere methanol som tilsætning til benzin. Virksomheden bruger en ny metode, hvor kuldioxid fra et geotermisk kraftværk er tilsluttet vand, ved at udnytte energien fra anlægget. Således nyttiggøres karbon fra kuldioxiden og bliver konverteret til et alternativt brændstof, hvilket igen mindsker CO2udledningen fra trafikken. I første omgang blandes methanol i en lille procentdel i benzin på en tankstation, men ved at udnytte anlæggets totale kapacitet vurderes det, at man kan dække en tredjedel af det årlige benzinbrug i Island. I fremtiden kan anlægget udvides yderligere, så det bliver muligt at blande det grønne methanol i al benzin i Island, uden at det vil kræve ændringer i køretøjer og infrastruktur. ${ }^{187}$

Carbon Recycling International er ikke det eneste selskab, der arbejder med løsninger på brændstof til biler. På dette område kan man

\footnotetext{
185 ÍSOR (2011). Information på hemmeside. http://www.isor.is.

186 Enex (2011). Information på hemmeside. http://www.enex.is/?PageID=139.

${ }^{187}$ Samtök iðnaðarins (SI). Carbon Recycling hefur framleiðslu á vistvænu eldsneyti. Frétt á heimasíðu 18. nóvember 2011. (Carbon Recycling begynder med produktion af miljøvenligt brændstof. Nyhed på hjemmeside 18. nov. 2011). http://www.si.is/malaflokkar/orku-og-umhverfismal/orku-ogumhverfisfrettir/nr/9305
} 
også nævne selskaberne Northern Lights Energy, som arbejder med indføring af elbiler, Icelandic New Energy som beskæftiger sig med brint som brændstof og med indføring af alternativ energi i transportsektoren iøvrigt, og virksomhederne Metan og Metanorka som arbejder med og har som formål at udvinde metan fra lossepladser og fra landbrug. I tillæg til dette har 3-4 virksomheder specialiseret i ændring af biler, så de kan køre på metan. Regeringen har støttet denne udvikling med skatteincitamenter. Yderligere har virksomheden Orkey i Akureyri startet produktion af biodisel fra restolie fra andre processer.

Nogle af de andre energitekniske løsninger, som islandske selskaber arbejder med, omfatter systemer for styring af brændsel og energibesparelser for to-takts motorer, energistyring i bygninger og udvikling af LED belysning til gartnerierhvervet og hydroponik. Et selskab har specialiseret sig i udvikling af små vandkraftværker, og to små virksomheder gennemfører forskning og udvikling vedrørende brug af tidevandsenergi.

\section{Geotermisk klynge}

I juni 2011 blev den islandske geotermiske klynge af virksomheder formelt etableret. I virkeligheden er klyngen todelt: For det første er der et forskningsbaseret klyngesamarbejde (GEORG) og på den anden side en forretningsklynge (Iceland Geothermal). Der lægges vægt på et godt samarbejde og kommunikation mellem disse, muligvis med henblik på, at GEORG og Iceland Geothermal forenes på et tidspunkt. ${ }^{188} \mathrm{Et}$ af klyngens store projekter i den nærmeste fremtid bliver konferencen Iceland Geothermal, der planlægges afholdt i november 2012 og derefter hvert andet år. Målet er, at dette fremover skal blive en af de vigtigste konferencer i forbindelse med geotermisk energi i Europa.

Marorka er ofte nævnt som et islandsk eksempel på de muligheder, der ligger i udviklingen af miljøteknologi, og ligeledes som et eksempel på et islandsk selskab, som har opnået en betydelig succes i dette felt på det globale marked. Grunden til virksomheden blev lagt i 1997. Siden er der blevet arbejdet intensivt på at udvikle teknologier, der kan reducere energiforbruget på skibe med vægt på brændstofs- og energistyringssystemer. Dette arbejde viste først store resultater omkring 10 år senere. I dag er Marorka verdens største virksomhed på dette område, med en helt unik løsning. Næsten hele produktionen eksporteres, og kunderne er spredt over hele verden. Sædvanligvis ligger der lange ventelister med ordrer. Virksomheden har også været aktivt involveret i

\footnotetext{
188 Hákon Gunnarsson og Póra Margrét Porgeirsdóttir (2011). Virðisauki í jarðvarma. Íslenski jarðvarmaklasinn; Vegferð og vegvísir. (På islandsk). (Merværdi i geotermisk varme. Den islandske geotermiske klynge; Rejse og vejviser). 2. udg., Gekon, september 2011.

http://www.gekon.is/images/stories/Vegferd\%20og\%20vegvisir.\%202nd\%20september\%202011.pdf
} 
uddannelsen af nye eksperter i miljøteknologi, bl.a. gennem projektet Marorka Energy Management Institute (MEMI). Dette er en del af virksomhedens fokus på det sociale ansvar, hvilken bl.a. går ud på at skabe en bedre forbindelse mellem universiteterne og den virkelige og praktiske anvendelse af energiteknologi og energistyring.

ReMake Electric er et andet selskab, der har opnået succes på det internationale marked. Virksomheden har udviklet innovative løsninger for elektrisk drift og vedligeholdelse med produkter og tjenester, der skaber et avanceret styringssystem for optimering af el-forbruget. Resultatet er reducerede omkostninger gennem øget energieffektivitet, reduceret elektrisk relaterede brandfarer og en reduktion af Carbon Footprint. ${ }^{189}$

Generelt er det en stor udfordring for islandske virksomheder at overvinde de økonomiske konsekvenser af et lille hjemmemarked kombineret med transport over lange afstande. Dermed er det ganske vanskeligt at nå gode internationale resultater.

\subsection{Arbejdet med efterspørgselssiden i Island}

Islandske myndigheter har af naturlige årsager ikke gjort meget for at fremme efterspørgslen efter miljøteknologier, da mulighederne er begrænsede på grund af lille hjemmemarked. Dette gælder især for teknologiindkøb, som kan bruges til at fremme udviklingen af nye løsninger. Det kræver ofte, at man sikrer salget af et mindste antal enheder af det nye produkt, som er vanskeligt at realisere i en lille $ø$ konomi. De virkemidler, som den islandske regering har taget for at fremme en større efterspørgsel er grønne offentlige indkøb på den ene side og ændringer af det lovgivningsmæssige system på den anden. På begge fronter er man dog ikke kommet så langt endnu.

I år 2003 startede staten og nogle islandske kommuner et formelt samarbejde om grøn offentlig indkøb under titlen VINN. ${ }^{190}$ Der arbejder man med opfølgning af statens politik om offentlig indkøb fra 2009. ${ }^{191}$ Til dette formål har VINN-projektets styregruppe bl.a. oversat en manual om grønne indkøb og oversat og lokaliseret europæiske og nordiske miljøkrav, som bruges i udbud. I tillæg til dette er man i gang med uddannelse blandt indkøbere i offentlige institutioner m.v. Den generelle opfattelse er, at dette arbejde allerede har givet betydelige resultater,

\footnotetext{
${ }^{189}$ Clean Tech Iceland (2011). Clean Tech Iceland: A Vision for Success. Draft, February 2011 - og - ReMake Electric. Information på hjemmesiden. http://www.remake-electric.com. 190 Grøn indkøb (VINN) (2011). http://www.vinn.is

191 Islands Regering (2009). Stefna um vistvæn innkaup ríkisins. Ríkið sem upplýstur vistvænn kaupandi. (På islandsk). (Statens politik om grønne offentlig indkøb. Staten som en informeret grøn indkøber). http://www.fjarmalaraduneyti.is/media/utgafa/Stefna_um_vistvaen_innkaup_rikisins_200903.pdf
} 
som bl.a. afspejles i producenternes indsats for at opfylde kravene i det nordiske miljømærke Svanen for at blive bedre placeret i udbud. Dette arbejde har dog sandsynligtvis ikke ført til øget efterspørgsel efter miljøteknologi som sådan.

Den islandske lovgivning er kun i et begrænset omfang blevet tilpasset på en sådan måde, der fremmer en øget efterspørgsel efter miljøteknologi. Det vigtigste eksempel herpå er dog ændringen i beskatningen af køretøjer, der trådte i kraft den 1. januar 2011, hvor afgifterne blev reduceret på køretøjer, der udnytter alternativ energi. Dette har ført til en stærkt øget efterspørgsel efter ændringer af konventionelle biler, så de kan køre på genvundet metan i stedet for benzin. Rapporten fra Parlamentets udvalg om fremme af grøn økonomi peger på flere muligheder i denne retning, herunder forslag om indførelse af forureningsafgifter (på NOx og SOx m.m.) for at øge efterspørgslen efter nye teknologier vedrørende brændstofforbrug i skibe m.v., samt om at indtægterne fra karbonafgifter bl.a. kan blive brugt til at fremme udvekslingen af energi i transportsektoren. ${ }^{192}$

En anden handling, som vil have en betydelig indvirkning på efterspørgslen efter miljøteknologi vil være et krav om tilsætning af vedvarende brændstoffer i fossile brændstoffer til en vis grad. Intet af dette er dog blevet gennemført endnu.

\subsection{Konklusion på Islands aktiviteter}

Det vurderes, at der er lidt over 40 virksomheder, som arbejder med miljøteknologi i Island. Af disse arbejder 25 med energiteknologi, herunder 8 med speciale i geotermisk energi. Den årlige omsætning skønnes at være 700 mio. DKK, mens eksporten vurderes til ca. 325 mio. DKK for året 2010. Der er allerede i Island er klar erkendelse af, at man skal have mere detaljeret information om virksomhederne, og hvordan de udvikler sig år for år. Et sådant materiale bør årligt opdateres, så virksomhederne selv og myndighederne kan følge udviklingen.

Der er generelt et stort behov for kortlægning af status og potentiale af miljøteknologi i Island for at identificere hvor styrkerne ligger, hvilken størrelse sektoren har, og hvad der er virksomhedernes største udfordringer.

Der er ingen tvivl om, at Island tidligere har gjort en enormt indsats for, at landet kan udnytte de rigelige geotermiske energikilder til elektricitet og varme. Island er verdenskendt for denne betydelige

192 Det Islandske parlaments udvalg for fremme af grøn økonomi (2011). Efling græns hagkerfis á Íslandi. Sjálfbær hagsæld -samfélag til fyrirmyndar. (På islandsk). (Fremme af grøn økonomi i Island. Bæredygtig velstand - et samfund som forbillede). http://www.althingi.is/pdf/Graent_hagkerfi.pdf 
indsats. På trods af dette eller måske også på grund af dette har Island kun i ganske få år beskæftiget sig med udviklingen og anvendelsen af miljøteknologier, sådan som det er fremkommet fra 2004. Myndighederne har været tilbageholdende og en målrettet indsats for miljøteknologi har manglet. Imidlertid har den private sektor været meget opmærksomme på nye muligheder, og på en meget kort tid er der vokset en række virksomheder frem på området. Myndighederne har en række forskellige instrumenter, der kan anvendes til at fremme en hurtigere udvikling, og i anbefalingerne fra Parlamentets udvalg om fremme af grøn økonomi findes der nogle målrettede forslag i denne retning. Faktisk er det nødvendigt, at myndighederne tager et større initiativ i denne henseende. De fleste virksomheder inden for miljøteknologi i Island eksporterer en del af deres produktion eller har planer om eksport. Trods dette er det vigtigt at have et godt hjemmemarked, især når produkterne er i udviklings- og testfasen. Her bør myndighederne hjælpe til med at etablere demonstrationsanlæg og gerne skabe en efterspørgsel efter produkterne om muligt.

Manglende forsikringer kan være et hinder for start-up virksomheder, både inden for miljøteknologi og andre sektorer. Dette er navnlig kreditforsikring, men kommercielle forsikringer i kobling til eksport er også vigtige i dette henseende. Finansieringen af nye virksomheder inden for miljøteknologi kunne lettes ved at oprette en særlig "grøn garantifond“, f.eks. i samarbejde mellem staten og finansielle institutioner, som ville garantere lån til voksende virksomheder i grønne aktiviteter. Ingen sådan fond er tilstede i Island. Man kunne også lære sig noget af Kvindernes lånegarantifond, der har opereret i Island i nogen tid. ${ }^{193}$

Íslandsstofa kunne anvendes mere aktivt end det sker for nuværende til at hjælpe til med at skabe forretninger i udlandet inden for miljøteknologi. Íslandsstofa arbejder meget med at tiltrække udenlandske investeringer til Island, samt bistå turisterhvervet, fiskeindustrien og andre parter i deres markedsføring. Imidlertid har miljøteknologi ikke været på organisationens prioriteringsliste. I forbindelse med dette opstår der behov for at styrke billedet af Island som et land med miljørigtige løsninger. Island har en helt unik position på det miljøteknologiske område, eftersom al elektricitet kommer fra vedvarende energi allerede. Dette bør markedføres langt bedre internationalt.

Det er blevet nævnt adskillige gange, hvor vigtigt det er at fremme uddannelse med henblik på at styrke den tekniske viden og færdigheder på miljøteknologiområdet. Specialisering indenfor dette område bør dog ikke ske på bekostning af tværfaglig viden, hvor teknisk viden er vævet

193 Velferðarráđuneytið (2011). Lánatryggingasjóður kvenna endurvakinn. Frétt á heimasíðu 8. mars 2011. http://www.velferdarraduneyti.is/frettir-vel/nr/32690 
sammen med emner inden for samfundsvidenskab, forretnings- og marketingområdet, for at nævne nogle få. Måske er der et behov for at slå uddannelsesinstitutioner sammen på dette område i Island og forbedre deres forhold til forskningsinstitutioner og andre dele af støttesystemet.

Effektiviteten i udnyttelsen af geotermisk energi i Island er stadigvæk begrænset, dersom det kun er muligt at producere elektricitet fra de varmeste dele, nemlig fra geotermisk damp. En stor mængde varmt vand går til spilde, da man allerede har mødt efterspørgslen efter varmt vand i de bolig- og industriområder, som ligger i overskuelig afstand fra de geotermiske kraftværker. Det burde være et mål at maksimere værdien af disse ressourcer ved at udnytte overskudsvarmen samt råvarer i røggassen. På dette område ligger der gode muligheder for innovation indenfor miljøteknologiområdet. Overskudsvarme og kuldioxid fra kraftværker kan f.eks. bruges til produktion af fødevarer i såvel små mængder som i store, og overskudsvarmen kan desuden anvendes i akvakultur og produktion af alger, som har den fordelagtige egenskab at være de af jordens organismer, som vokser hurtigest. Fra alger kan man blandt andet producere forskellige kemiske produkter, biobrændsel og foder til opdrætsfisk og husdyr, for at nævne nogle få. Tilsvarende vil det være muligt at konvertere svovlbrinte (H2S) i ren svovl til industriel produktion, og svovlbrinte frigives i store mængder fra nogle geotermiske kraftværker, som f.eks Hellisheidarvirkjun ved Reykjavik.

Miljøteknologiens udvikling drejer sig ikke kun om teknologisk innovation. Lovgivning, styring og infrastruktuer er også afgørende. Der opstår et behov for at undersøge på, hvilken måde virksomhedernes omstændigheder kan forbedres gennem samarbejde mellem den offentlige og den private sektor, etablering af klynger, uddannelsesmuligheder, nye måder at finansiere o.s.v.

Island er i de fleste henseender en ideel platform til at teste forskellige nyskabelser i brugen af vedvarende energier inden for transport. Der er endvidere et behov for at undersøge nærmere, hvordan det er muligt at udnytte sådanne muligheder i samarbejde mellem den offentlige og den private sektor.

Miljøministeriet i Island giver årligt en miljøpris (kuðungurinn) til en person eller virksomhed, som synes at have været $\mathrm{i}$ front med miljøarbejdet. Disse priser har en generel karakter, men der gives ingen særlig pris til præstationer indenfor miljøteknologi. En sådan „clean tech-pris" kunne fungere som et vigtigt incitament for enkeltpersoner og virksomheder inden for miljøteknologi. I denne forbindelse har man blandt andet henvist til en danske pris. ${ }^{194}$ 
Vigtigst af alt er, at de islandske myndigheder udarbejder en strategi og en langsigtet handlingsplan for en fremme af miljøteknologi. En sådan politik bør være særlig opmærksom på finansielle støtteordninger for de virksomheder, som arbejder med at udvikle nye løsninger på dette område, grøn kreditforsikring, anvendelse af økonomiske incitamenter og de enkelte institutioners rolle i arbejdet. Tilskudssystemet bør kunne forenkles, og man må sikre, at der eksisterer den viden og åbenhed, der er nødvendig for at fremme denne industri, som i de fleste tilfælde kræver en tværfaglig indsigt. 



\section{Norges indsats for miljøteknologi 2004-2011}

I stedet for ordet miljøeffektiv teknologi, anvendes miljøteknologi i dette kapitel om Norges indsats. Dette skyldes, at man i Norge bruger begrebet miljøteknologi konsekvent, og det synes som om alle gør det. Det norske begreb miljøteknologi dækker over det samme som miljøeffektiv teknologi.

\subsection{Norsk erhvervslivs aktiviteter inden for miljøteknologi}

Der har længe manglet en beskrivelse af hvor mange virksomheder, omsætning, beskæftigede og andre forhold af interesser, der eksisterer i Norge. Konsulentfirmaet Menon har for nylig opgjort antallet af virksomheder i Norge i et notat i november 2011. ${ }^{195}$ Menon tillægger enkelte virksomheder en miljøvægt, hvis kun andele af virksomheden har med miljøteknologi at gøre, og med denne miljøvægt tages ikke de øvrige dele af virksomheden med i omsætning, værdiskabning og antal ansatte. Menon er selv opmærksom på, at denne opgørelsesform er konservativ og fører til reducerede størrelser, men er nok mere realistisk i opgørelsesform. Menon har i sit notat opgjort antallet af miljøteknologiske virksomheder på kategorier eller brancher. Resultatet bliver 300 virksomheder og en omsætning på 18 mia. NOK i 2010, samt en totalbeskæftigelse på 6.000 ansatte. ${ }^{196}$

I Norge har myndighederne vurderet, hvordan man kan udvikle statistik om virksomheder inden for miljøteknologi. Der arbejdes videre med denne problemstilling. Det er vigtigt, at en statslig aktør i sidste ende bliver ansvarlig for denne statistik om virksomheder, så der på sigt kan opstå mere konsensus om antal af virksomheder, kategorier og områder etc.

195 Menon Business Economics: Miljøteknologi i Norge, november 2011, 26 sider.

196 For de specifikke tal henvises til Menons notat nævnt i noten ovenfor. 


\subsubsection{Eksport af norsk miljøteknologi}

Menon har også lavet en vurdering af eksporten af miljøteknologi fra Norge. ${ }^{197}$ Denne vurdering konkluderer, at eksporten i 2009 var på 6,5 mia. NOK og i 2010 var den på 6,7 mia. NOK. Opgørelsen bygger på 114 selskaber, hvilket må siges at være et begrænset antal i forhold til opgørelsen ovenfor af antallet af virksomheder. Herved fås et ret konservativt tal, som med en bredere definition givetvis ville blive større. Et sådant beløb kan måske være ca. 10 mia. NOK, men dette er ren spekulation. Menon er for øvrigt det eneste konsulentselskab i Norge, som foretager en sådan opgørelse.

Ifølge Menon er norske selskaber specielt store indenfor solenergi og teknologi relateret til vandkraft, og i 2009 dækkede disse to områder lidt over halvdelen af eksporten. Denne andel blev tilmed større i $2010 .{ }^{198}$

Af andre områder som også er betydelige kan ifølge Menon nævnes energieffektivitet, affaldssortering (især Tomra) og teknologi knyttet til vindkraft.

Det offentlige eller staten bør nok også tilslutte sig arbejdet med statistik om eksport på dette område, især hvis der nationalt er høje ambitioner om vækst og øget eksport.

\subsection{Vurderinger og initiativer for miljøteknologi i Norge}

Dette afsnit forsøger, efter en kort introduktion til centrale aktører, at give et historisk tilbageblik over, hvad der er sket i Norge vedr. miljøteknologi i perioden. Dermed er der tale om en kronologisk gennemgang af aktiviteter baseret på de tilgængelige rapporter. Det kan måske indvendes, at dette kun har en historisk interesse og er mindre relevant i en forståelse af området i dagens Norge. Omvendt må man dog fremhæve, at 7 år faktisk er ganske få år ud i et udviklingsperspektiv, og at det er meget vanskeligt at forstå situationen i dagens Norge uden dette tilbageblik.

\section{Centrale aktører i Norge på statsligt plan}

Hovedaktørerne blandt de norske ministerier er Miljøministeriet og Erhvervsministeriet, dvs. Miljøverndepartementet og Nærings- og Handelsdepartementet. Miljøverndepartementet er ansvarlig for den miljømæssige side af sagen med regulering etc., samt vigtigheden af miljøteknologi for at nå miljømål, mens Nærings- og Handelsministeriet er an-

197 Menon Business Economics: Miljøteknologi i Norge, november 2011, 26 sider.

198 For de helt specifikke tal se Menons notat nævnt i noten ovenfor. 
svarlig for det erhvervsmæssige element. Olie- og Energiministeriet i Norge spiller også en helt centralt rolle i arbejdet med energi og alternativ energi etc.

Klima- og Forurensningsdirektoratet, tidligere Forurensningstilsynet, er den udførende styrelse under Miljøverndepartementet med hensyn til miljøteknologi. Denne styrelse har stået for ganske meget af arbejdet med miljøteknologi i form af drøftelser fra miljøsiden og styring af rapporter i Norge.

Innovasjon Norge er den centrale aktør i Norge for fremme af miljøteknologi, når der ikke tales om energiområdet. Innovasjon Norge er helt central i den nye strategi fra maj 2011, jf. nedenfor.

Norges Forskningsråd disponerer over de økonomiske virkemidler til at bidrage til den forskningsmæssige side af innovasion og teknologiudvikling i Norge. Man kan blandt andet nævne en meget central satsning på en række forskningscentre indenfor vedvarende energi fra februar 2009 og senere.

Enova blev oprettet i juni 2001 og begyndte sit arbejde i begyndelsen af 2002. Enova er en offentlig ejet virksomhed ejet af Olie- og Energiministeriet. Hovedformålet med Enovas aktiviteter er en miljøvenlig omlægning af forbrug og produktion af energi i Norge til mere effektiv energiforbrug, øget produktion af vedvarende energi og miljøvenlig forbrug af naturgas.

\section{Teknologirådets vurdering af miljøteknologi i Norge}

I nær tilknytning til debatten om bæredygtig udvikling interesserede det norske Teknologiråd sig i 2004/05 for bærekraftig innovations- og teknologipolitik. Og rådet gennemførte i foråret 2004 en rundbordshøring herom med forskellige aktører fra erhvervsliv, forskning og forvaltning. Teknologirådet er et uafhængig, offentligt organ, som skal rådgive Stortinget og forskellige myndigheder og fremme en offentlig debat om muligheder og konsekvenser ved ny teknologi for samfundet og for den enkelte.

I april 2005 udgav Teknologirådet derpå en rapport om Bærekraftig innovation og teknologipolitik i Norge. ${ }^{199}$ I rapporten gennemgås den hidtidige norske indsats for miljøteknologi og bærekraftig miljøteknologi, som man anvender for begrebet miljøeffektiv teknologi. Rapporten analyserer de centrale forvaltningsorganer, statslige selskaber og dokumenter, som omhandler forholdet mellem innovation og bæredygtig udvikling. Rapporten kan ses som en helt central rapport i vurderingen af status for miljøteknologi i Norge i 2005.

Rapporten slår fast, at teknologi er af afgørende betydning i fremme af bæredygtig udvikling, og at de offentlige myndigheder spiller en vigtig

199 Teknologirådet: Bærekraftig innovasjons- og teknologipolitik, rapport 2, 2005, 56 sider. 
rolle i fremme af bæredygtig innovation. Rapporten vurderer, at brugen af virkemidler i Norge til fremme af miljøteknologi er alt for lidt koordineret, og at der bruges for få virkemidler til dette arbejde. Rapporten vurderer ligeledes, at norsk politik på området er fragmenteret og ikke særlig konkret eller fokuseret. Forvaltningsmæssig er mange institutioner involveret i forskningspolitikken på området, men ingen har et hovedansvar for at fremme bæredygtige elementer i innovationspolitikken.

Rapporten beskriver også hvilke institutioner, som giver offentlige midler i støtte til projekter.

Enova nævnes etableret i 2001/02 med det formål at fremme miljøeffektiv omlægning af produktion og forbrug på energiområdet i Norge. Enova tildeler midler fra Energifondet, som i 2003 rådede over 539 mio. NOK. RENENERGI nævnes også som et satsningsområde under Norges Forskningsråd med 160 mio. NOK til disposition i 2004.

Rapporten kommer med flere anbefalinger, heraf de vigtigste er:

- Den politiske dagsorden bør skærpes for at fremme bæredygtig innovation

- Brugen af virkemidler må koordineres bedre, og der skal være en bedre ansvarsfordeling mellem de involverede offentlige aktører

- Erfaringer fra norske virksomheder og projekter skal samles ind og systematiseres

- Konsekvenser for miljøet bør have en mere fremtrædende rolle i den måde offentlige bevillinger gives på i Norge

- Der bør udvikles indikatorer til at vurdere teknologiers bidrag til bæredygtig udvikling

- Det bør vurderes om Norge skal satse på et begrænset antal områder eller støtte mange områder. I tilfælde af det første peges på: olie- og gassektoren, fiskerisektoren og turisme

Samlet set må det vurderes, at rapporten giver en udmærket status for indsatsen i Norge i 2004/05.

\section{Regeringens udmeldinger 2004-2007}

I Stortingsmelding nr. 21 (2004-05) om Regeringens miljøpolitik og rigets tilstand fremhæver regeringen, at man vil gøre Norge til et foregangsland for miljøteknologi. ${ }^{200}$ Regeringen vil bl.a. øge forskningen og stimulere udnyttelsen af forskningsresultaterne bedre.

I Stortingsmelding nr. 26 (2006-07) om Regeringens miljøpolitik og rigets miljøtilstand gennemgår regeringen under overskriften Miljø og Værdiskabelse, hvordan man vil satse på miljøteknologi. ${ }^{201}$ I denne ud-

200 Stortingsmelding nr. 21 (2004-05): Regjeringens miljøpolitikk og rikets miljøtilstand.

201 Stortingsmelding nr. 26 (2006-07): Regjeringens miljøpolitikk og rikets miljøtilstand. 
melding gennemgås muligheden for at satse på miljøteknologi, og regeringen vil:

- Opfordre til, at der samarbejdes bedre mellem Norges Forskningsråd, Innovasjon Norge og Statens Forurensningstilsyn

- Styrke Norges Forskningsråds arbejde for at fremme miljøteknologi i prioriterede programmer

- Styrke innovasjon Norges arbejde for at fremme miljøteknologi

- Koble forskning og udviklingsaktiviteter sammen med miljøregulering

- Satse på at udvikle ny teknologi til at reducere udslippene fra gaskraftværker

- Videreudvikle arbejdet med at fremme miljøteknologi, bl.a. i innovationspolitikken

- Bidrage til at øge efterspørgslen efter miljøteknologi ved at:

a) Integrere miljøteknologi bedre i udviklingsarbejde og eksportsatsninger

b) Styrke offentlige grønne indkøb

c) Fremme forbrugerrettede tiltag som miljømærker og viden om miljøbelastninger

\subsubsection{Miljøteknologiprojektet ved Statens Forurensningstilsyn}

I januar 2005 blev der etableret et miljøteknologiprojekt hos Statens Forureningstilsyn, nu kaldet Klima- og Forurensningsdirektoratet. Begrundelsen for projektet var, at miljøteknologi er vigtig for at løse miljøproblemer i Norge og internationalt, og en bevidst satsning kunne udvikle og styrke norsk erhvervsliv. På denne baggrund skulle projektet analysere, hvordan Norge kan blive et foregangsland indenfor miljøteknologi. Der samarbejdes tæt med Innovasjon Norge og Norges Forskningsråd om en satsning.

I projektets første fase blev drivkræfter og barrierer for udvikling og brug af miljøteknologi klarlagt. Også centrale aktørers synspunkter og behov med særlig vægt på myndighedernes rolle blev kortlagt.

Konsulentfirmaet ECON analyserede i 2006 virkemidler for fremme af miljøteknologi for Statens Forurensningstilsyn. ${ }^{202}$ Rapporten gennemgår forskellige virkemidler til at fremme miljøteknologi og kommer med en række overordnede anbefalinger. Der er tale om en rimelig traditionel oplistning af virkemidler.

202 ECON: Virkemidler for å fremme miljøteknologi. Rapport 2006-019, 2006, 72 sider. 
Som en del af afslutningen på miljøteknologiprojektet offentliggjorde Statens Forurensningstilsyn sammen med Innovation Norge og Norges Forskningsråd i april 2007 et forslag til en samarbejdsmodel og tiltag for miljøteknologi i Norge fra 2008. ${ }^{203}$

Forslagets kerne er, at der skal satses 200 nye mio. NOK. om året i 10 år til at fremme miljøteknologi i Norge. De nye midler skal indgå i eksisterende programmer og tilskudsordninger og bruges på at fremme miljøteknologi bredt. Målet er at give forskningen et væsentligt løft, at reducere risikoen ved udvikling for at fremme denne, at øge demonstration og verifisering af ny miljøteknologi, samt at bidrage til at kommercialisere eksisterende og ny norsk teknologi internationalt.

Det anbefales, at følgende skal ske for de 3 institutioner:

- Forskningsindsatsen for miljøteknologi hos Norges Forskningsråd skal øges

- Innovasjon Norges ordninger til norske erhvervsvirksomheder skal styrkes, så der kan gives mere støtte til udvikling, demonstration og verifisering af miljøteknologi, samt kommercialisering internationalt

- Statens Forurensningstilsyn skal styrke sin kompetence via myndighedsudøvelsen til at øge efterspørgslen efter miljøteknologi

Forslaget skitserer også en konkret samarbejdsmodel, som indebærer en fælles overbygning for miljøteknologi mellem de 3 institutioner. Der skal oprettes et samarbejdsorgan, kaldet MT-organet (Miljøteknologiorganet), som skal varetage koordineringen af indsatsen. MT-organet foreslås delt op i et udvalg og i et sekretariat.

Forslaget omfatter også konkrete tiltag til fordeling af de foreslåede midler i 2008 og de efterfølgende år.

Statens Forurensningstilsyn udgiver ydermere i juni 2007 en publikation, som udbygger det ovennævnte forslag og især fokuserer på, hvad Statens Forureningstilsyn foreslår at gøre selv. ${ }^{204}$

På efterspørgselssiden foreslås det at:

- Styrke det internationale samarbejde som påvirker efterspørgslen efter miljøteknologi

- Styrke opfølgningen af at forureneren betaler omkostningerne for sine udslip

- Øge brugen af grønne afgifter i kombination med emissionskrav og andre reguleringer

\footnotetext{
203 Innovasjon Norge, Norges Forskningsråd og Statens Forurensningstilsyn: Miljøteknologi, forslag til samarbeidsmodell og tiltak fra 2008, april 2007, 11 sider.

204 Statens Forurensningstilsyn: Miljøteknologi - hvordan kan Norge bli et foregangsland? Miljøgevinst hjemme og ute, verdiskapning hjemme, juni 2007, 25 sider.
} 
- Bruge offentlige indkøb/grønne indkøb mere aktivt

- Styrke miljøforvaltningernes teknologikompetence

- Styrke samarbejdet mellem miljøforvaltningen og erhvervspolitikken og afgiftspolitikken

\subsubsection{Strategisk Råd for miljøteknologi}

I december 2008 blev der oprettet et strategisk råd for miljøteknologi. Formålet med Rådet var at hjælpe med gode ideer til udvikling og opfølgning af regeringens politik for miljøteknologi. Nærings- og handelsministeren ledede møderne med bistand fra miljø- og udviklingsministeren. Rådet tæller 25 medlemmer og har p.t. følgende 20 erhvervsvirksomheder og erhvervsnetværk repræsenteret: Tomra, GreenBusinessNorway, Aanderaa Data Instruments, StatoilHydro, Scatec, Skanska, Veritas, Orkla, Think, Umoe, Yara, Norsk Hydro, Veolia, Cambi, Refa Frøystad Group, Norgesgruppen, Forum for miljøteknologi, Norner Innovation, Sweco og Aker. Rådet har også repræsentanter for vidensmiljøer: NTNU, SINTEF, regionale myndigheder (Fylkesmannen i Vestfold) arbejdstagersiden (LO) og miljøbevægelser (Bellona). I tilknytning til Rådet er der etableret et underudvalg som ledes af Miljøverndepartementet med bistand fra Næringsog Handelsdepartementet med repræsentanter for erhvervsorganisationer (NHO, Norsk Industri, HSH), arbejdstagersiden (LO, Fellesforbundet) og virkemiddelapparatet (Innovasjon Norge, Norges Forskningsråd, Klima- og Forurensningsdirektoratet og Direktoratet for forvaltning og IKT.

\section{Grønne penge}

I maj 2009 udgives en publikation med titlen Grønne penge. ${ }^{205}$ Publikationen er en del af det arbejde som Nærings- og handelsdepartementet og Miljøverndepartementet gennemfører i foråret 2009 for at fremme en strategiudvikling af miljøteknologi. I rapporten gennemføres en vurdering af økonomiske stimuleringstiltag rettet mod miljøteknologi i Norge og 9 andre lande: Sverige, Danmark, Finland, Tyskland, Nederlandene, Storbritanien (UK), USA, Canada og Japan. Målet med kortlægningen har været at analysere, hvordan de 10 lande udformer virkemidler til fremme af miljøteknologi.

Kortlægningen dokumenterer et stort antal virkemidler og spredning i anvendelsen af disse virkemidler. Det centrale i virkemidlerne er dog generelle tilskudsordninger og særlige virkemidler for at fremme miljøteknologi/produkter.

Rapporten konkluderer:

205 Siv.ing. Tor-Petter Johnsen: Grønne penger. Et udvalg offentlige økonomiske stimuleringsmidler for miljøteknologi i 10 land, 10. maj 2009, 55 sider. 
- Generelt findes der mange forskellige typer økonomiske virkemidler fra forsknings- og udviklingstilskud til skatter og afgifter. I Europa bruges primært offentlige tilskud og afgifter, mens man i USA støtter markedsintroduktion og skatteincitamenter

- Der findes eksempler på støtteordninger for alle faser af innovasionsprocessen. Vægten i tilskud varierer fra land til land

- Alle lande tilbyder både øremærkede og generelle virkemidler; som regel i en kombination baseret på det nationale kompetence- og erhvervslivsbillede

- Valg af satsningsområde er landeafhængig, men stort set alle lande har fokus på vedvarende energi

- Det er ikke muligt at sige, at noget land har haft en specielt vellykket strategi sammenlignet med Norge

Den store fordel ved rapporten eller analysen er, at den gennemgår enkelte teknologier og sammenligner disse land for land. Herved får man en klar fornemmelse af, hvad de enkelte lande har gjort på et teknologiområde. En svaghed ved publikationen er, at sammenligningen foregår tidsmæssigt på et tidspunkt, hvor man ikke er kommet særlig langt i mange lande. En anden svaghed er, at man ikke kommer dybt nok ned i materien for, hvad de enkelte lande har gjort.

\section{Miljøteknologi, Menon publikation}

I maj 2009 udgives ligeledes en publikation om miljøteknologi, hvor firmaet Menon kortlægger norske miljøteknologivirksomheders markeds- og teknologistatus for Nærings- og Handelsdepartementet og Miljøverndepartementet. ${ }^{206}$ Rapporten er også et delarbejde i kortlægningen af vigtige elementer for udformningen af en ny strategi for miljøteknologiske virksomheder. I analysen er virksomhedernes erfaringer med miljøreglerne, det offentlige virkemiddelapparat og det offentlige som indkøber, centrale parametre.

Resultaterne i rapporten er baseret på en spørgeskemaundersøgelse, som blev gennemført i foråret 2009. Formålet har været at indsamle viden om, hvordan virksomhederne oplever udfordringer og forhindringer, som præger markedet for deres produkter og tjenester.

Kortlægningen har baseret sig på følgende:

- En undersøgelse i spørgeskemaform sendt til 280 virksomheder, som repræsenterer et bredt spektrum af miljøteknologivirksomheder i Norge. 139 virksomheder besvarede spørgeskemaet

206 Menon: Miljøteknologi. Potensial og hindre for utvikling av norske konkurransedyktige bedrifter, mai 2009, Menon-publikasjon nr. 7, 108 sider. 
- Interviews af 85 virksomheder af de 139 virksomheder med det formål at uddybe og kvalitetssikre informationerne i svarene, samt få yderligere oplysninger

- Gennemførelse af 5 dialogmøder med 50 virksomheder, som repræsenterer udvalgte teknologiområder

Kortlægningen fokuserer på 5 centrale problemstillinger:

- Hvor modne er teknologierne, og hvor langt er der frem til evt. kommercialisering?

- Hvor findes, og hvor vokser markedet for miljøteknologi? Hvad driver denne efterspørgsel?

- Hvad er de vigtigste barrierer og drivkræfter for udvikling, kommercialisering og salg af miljøteknologi i Norge og til udlandet?

- Hvilken rolle spiller miljøreguleringer for teknologisk udvikling, kommercialisering og salg af miljøteknologi?

- Hvilken rolle spiller det offentliges politik og virkemidler (herunder offentlig indkøbspolitik) for teknologisk udvikling, kommercialisering og salg af miljøteknologi?

Yderligere 2 centrale spørgsmål er blevet forfulgt:

- På hvilke områder er norske virksomheder stærke internationalt?

- Hvor centralt står de stærke erhvervsklynger i Norge i udviklingen af miljøteknologi?

Af virksomhederne, som svarede, har 2/3 miljøteknologi, som kerneområde, mens resten også fokuserer på andre teknologiområder. Virksomhederne med miljøteknologi som kerneområde omsætter for ca. 20 mia. NOK om året ${ }^{207}$ og her er eksportandelen stor. Mønsteret præges af nogle få større virksomheder. Der er ca. 4.600 ansatte i disse virksomheder.

Ved analysen er der identificeret et antal policyrelevante erfaringer, særtræk og anbefalinger, som er tilvejebragt ud fra et større antal virksomheders udsagn og på tværs af teknologiområder:

Resultater:

- Mange norske miljøteknologivirksomheder har udviklet sig i tilknytning til de store erhvervsklynger i Norge, dvs. det maritime, olie og gas, fiskesektoren, metaller/materialer. Mange af disse virksomheder befinder sig i grænselandet mellem flere af disse klynger, og det må vurderes, at der er et stort potentiale for vækst

${ }^{207}$ Der gøres opmærksom på, at dette er en tidligere opgørelse end Menons senere opgørelse for 2010 på 18 mia. NOK. 
- Kundedrevet teknologiudvikling er begrænset. Kunderne er ikke særlig aktive i udvikling af teknologi

- Det er virksomhedernes opfattelse, at miljøregler og anden lovgivning er hoveddriveren for teknologiudvikling. På mange områder ville der ikke være en efterspørgsel, hvis det ikke var for den offentlige regulering

- Det er virksomhedernes opfattelse, at virkemiddelapparatet svigter $\mathrm{i}$ virksomhedernes tidlige kommercialiseringsfase. Der er et stort behov for at udvikle virkemiddelapparatet rettet mod virksomhedernes kommercialiseringsfase

- Potentialet i offentlig indkøbspolitik udnyttes ikke godt nok. Gennem spørgeundersøgelsen kommer det frem, at norske myndigheder kun i begrænset omfang er initiativtager til teknologiudvikling

- Virksomhederne oplever, at der er mangel på ambitioner i miljøpolitikken. Virksomhederne mener endvidere, at selv når ambitionerne er til stede, føres de ikke særligt ofte ud i livet

- Virksomhederne mener, at åbne standarder og informationsdeling bør ligge til grund for regulering og formidling af offentlig information

- Virksomhederne ønsker rettighedsbaserede tilskudsordninger, som alternativ til ansøgningsordninger

- Der er et stort behov for at udvikle international sammenlignelig statistik, så norske miljøteknologivirksomheder kan sammenligne sig med virksomheder i andre lande

Generelt kan man sige om publikationen, at den indeholder mange detaljerede informationer, hvilket er en styrke. Den bærer dog også præg af at være tilvejebragt over relativt kort tid, så det virker ikke helt, som om man har fået analyseret samtlige informationer tilstrækkeligt. En anden svaghed synes at være, at rapporten gengiver virksomhedernes synspunkter uden at sammenholde disse med anden viden.

\section{Mål og succeskriterier for en national strategi for miljøteknologi}

Endelig udgives også i maj 2009 en rapport fra Statens Forurensningstilsyn om mål og succeskriterier for en national strategi for miljøteknologi. ${ }^{208}$ Dette notat har til formål at beskrive forskellige tilgange til mål og succeskriterier for udvikling af miljøteknologi. I notatet gennemgås forskellige typer af målsætninger: samfundsmål eller overordnede mål, procesmål/aktivitetsmål, resultatmål, samt effektmål. I denne drøftelse af hvordan man kan opstille målsætninger og forfølge disse, anvendes gennemgange af andre lande, som firmaet Econ Pöyry har lavet for Statens Forureningstilsyn. 
Rapporten har karakter af et notat, dvs. måske i første omgang tænkt til internt brug, men alligevel offentliggjort, fordi det er et udmærket notat om målsætninger, og hvordan man kan forholde sig hertil. Notatet kommer dog ikke med endelige konklusioner og må betragtes som et procesnotat.

\section{Econ Pöyrys rapport om Rammeverk for utvikling af miljøteknologi} Econ Pöyry udarbejder en rapport for Miljøverndepartementet med udgivelse i februar 2010 om grundlaget for udvikling af miljøteknologi. ${ }^{209}$ Rapporten berører principielle spørgsmål knyttet til offentlig støtte til udvikling af miljøteknologi. Econ Pöyry har analyseret 5 landes miljøpolitiske aktiviteter: Sverige, Danmark, Nederlandene, Storbritanien og Canada, samt hertil EU-kommissionens aktiviteter.

Analysen har lagt vægt på følgende problemstillinger:

- Hvorfor og hvordan bør offentlige myndigheder støtte udvikling af miljøteknologi?

- Hvordan har myndighederne begrundet og udformet virkemidler med sigte på at støtte miljøteknologi i 5 udvalgte lande?

- Hvordan kan et rammeværk for identifisering, prioritering og satsning på udvalgte områder inden for miljøteknologi udformes?

Studiet fremhæver følgende observationer, hvad angår studiet af de andre lande:

- Alle landene ser udviklingen af miljøteknologi som et vigtigt erhvervspolitisk satsningsområde, baseret på forventet stærk vækst i efterspørgslen efter miljøteknologi internationalt. Hertil ser landene naturligvis også miljøteknologi, som vigtige i opnåelsen af miljøpolitiske målsætninger

- Ansvaret for miljøteknologi er delt mellem departementer med ansvar for miljøspørgsmål og departementer med ansvar for erhvervsspørgsmål. I nogle lande har departementer for forskning og innovasion også en central rolle

- Både i de generelle policydokumenter og i metoderne, som nogle af landene forfølger, lægges der vægt på både det erhvervspolitiske hensyn og det miljøpolitiske hensyn i bidraget til bæredygtig udvikling

- Udviklingen i miljøteknologi i et land sker typisk, hvor landet allerede har komparative fortrin

- Flere af landene har identificeret behov for bedre koordinering af virkemidler og samarbejde mellem forskellige aktører 
- Flere af landene har fremhævet demonstration og testning af miljøteknologi blandt de offentlige virkemidler

- Flere af landene har udviklet nye metoder til at systematisere arbejdet med at prioritere mellem forskellige miljøteknologier

Rapporten kommer også med flere anbefalinger:

- Myndighederne bør være forsigtige med at give særlige præferencer til enkeltteknologier, men koncentrere sig om at prioritere mellem forskellige miljøteknologiområder

- I en sådan prioritering bør myndighederne tilstræbe en politik, som er neutral ex ante. De forskellige miljøteknologiområder bør testes ud fra et fælles sæt af kriterier og målsætninger, så særinteresser ikke fremmes i selektionsprocessen

- Prioriteringen bør udformes så den kan opfange muligheder, som ligger på tværs af eksisterende sektorer. Nye muligheder skal helst ikke falde mellem flere stole i virkemiddelapparatet

Rapportens styrke er måske, at den foreslår en særlig rammemodel for identificering, prioritering og satsning af særlige områder inden for miljøteknologi i Norge. Man lægger i denne anbefaling af rammemodel op til følgende:

- Det er vigtigt at identificere målsætninger og foretage gapsanalyser mellem mål og virkelighed

- Det er vigtigt at vurdere potentielle satsninger i Norge ud fra styrken i erhvervsklynge og områderne klima/miljøeffekt

- Ved forskellige teknologiområder bør man vurdere innovationssystemet og behovet for udvikling heraf tilpasset det særlige teknologiområde

- Efterfølgende må man analysere, hvordan de enkelte virkemidler skal udformes eller styrkes

- Koordinering af indsatsen bør prioriteres, da den helt klart er underprioriteret hidtil

\section{Menon rapport om Miljøteknologi og nationale fortrin}

I snæver kobling til den ovenfor nævnte rapport under afsnit 2.8 har firmaet Menon udarbejdet en rapport om Miljøteknologi og nationale fortrin, som udgives i januar 2010. ${ }^{210}$ Rapporten supplerer dermed den nævnte rapport fra Econ Pöyry. Rapporten har med udgangspunkt i Porters klyngeteori forsøgt at identificere miljøteknologiområder, som det kunne være

210 Menon: Miljøteknologi og nasjonale fortrinn. Miljøteknologiområder i Norge med potensial for internasjonal vekst, januar 2010, 67 sider. 
interessant for Norge at satse på. Man finder frem til 8 miljøteknologiske områder, som vurderes at være interessante for norsk satsning:

- Hydrobaserede små kraftanlæg

- Offshore vind

- Rensning af ballastvand

- Rensning af afløbs- og drikkevand

- Vandforsyning fra dybe reservoirer

- Avancerede, trådløse sensorer og integrerede sensornetværk

- Miljøvenlige energikilder i nationale net

- Avancerede miljøovervågnings- og beslutningsstøttesystemer

Disse teknologiområder beskrives i detaljer i rapporten. Et særlig interessant afsnit i rapporten er nogle norske eksempler på teknologier, der allerede har opnået international succes. De vil blive omtalt nedenfor.

\subsection{Den norske regerings strategi for miljøteknologi i 2011}

I maj 2011 udgiver regeringen sin strategi for miljøteknologi: „Næringsudvikling og grønn vekst“. ${ }^{211}$ Man bør være opmærksom på den erhvervsvenlige titel, idet overskriften signalerer større fokus på erhvervsudvikling end på miljøaspekter, selvom dette måske ikke har været intentionen. Den offentliggøres af Nærings- og Handelsdepartementet og Miljøverndepartementet. Det må siges at være en helt afgørende markering for indsatsen i Norge, at der nu kommer en officiel regeringsstrategi. Hermed opsummeres analyser, debatter, strategi etc. i et officielt regeringsdokument for fremtiden.

Strategien er på ca. 30 sider med nogle vigtige bilag. Formålet erklæres at være tosidet: dels at skabe national værdiskabelse og erhvervsudvikling, dels at bidrage til at fremme regeringens miljømål. Strategien indgår derfor både som en del af erhvervspolitikken og som en del af miljøpolitikken, om end det må være rimeligt at konkludere, at de erhvervspolitiske virkemidler og instrumenter har fået størst vægt i strategien.

Regeringens strategi for miljøteknologi omfatter 6 punkter eller dimensioner:

- Kommercialisering og teknologitestning

- Forskning og kompetenceudvikling

211 Nærings- og Handelsdepartementet og Miljøverndepartementet: Næringsutvikling og grønn vekst. Regjeringens strategi for miljøteknologi, 05/2011, 46 sider. 
- Netværk og samarbejde

- Miljøreguleringer

- Anskaffelser i offentlige og private virksomheder

- Videre udvikling af vidensgrundlaget for politikken

I tillæg til tiltag indenfor disse områder opstiller regeringen et program for miljøteknologi, som skal koordinere virkemidlerne og videreudvikle strategien. For detaljerne i programmet henvises til punktet herom nedenfor.

Arbejdet med regeringens strategi har stået på ganske længe, f.eks. blev der orienteret herom på det Strategiske Råds møde i august 2010. Medlemmerne i rådet kom med en række forslag til strategien, bl.a. Forum for Miljøteknologi, en interesseorganisation på området, som sendte et brev til regeringen om forslag til regeringens kommende strategi. ${ }^{212}$

\section{Ad 1) Kommercialisering og teknologitestning}

Under denne overskrift vil regeringen:

Forbedre rammevilkårene gennem etablering af et 3-årigt program for kommercialisering af miljøteknologi til 500 mio. NOK

- Gøre en særlig indsats for udvalgte satsningsområder, bl.a. gennem prioritering og øget koordination af offentlige virkemidler

- Udvide Skattefunn-ordningen til også at omfatte pilot- og demonstrationsanlæg

- Følge op på verifikationssystemer internationalt og vurdere systemer for norske miljøteknologier i lys af dette

Regeringen giver allerede i dag støtte til kommercialisering og teknologitestning af miljøteknologi gennem relevante programmer og satsninger blandt andet i Innovasjon Norge, Enova, og Transnova og regeringens betydelige satsning på carbonopsamling og -lagring. Regeringen vil fremover bruge en bevilling på 500 mio. NOK over 3 år til at fremme miljøteknologi og testning heraf.

Denne bevilling på 500 mio. NOK kommer som en ekstra indsats til, at der allerede er blevet bevilget i alt 140 mio. NOK til en satsning på statsbudgettet for 2010. Heraf er de 100 mio. NOK blevet øremærket til at støtte projekter med 2. generations biobrændstof. Innovasjon Norge fik til opgave at forvalte bevillingen som en støtteordning til pilot- og demonstrationsprojekter til udvikling af miljøteknologi. Der er bevilget yderligere 140 mio. NOK til at videreføre ordningen i 2011. Og i tilknytning hertil er der tilført ordningen 117 mio. NOK fra programmet for

212 Forum for Miljøteknologi: Regjeringens miljøstrategi, 21. juli 2010, 3 sider. 
miljøteknologi i 2011, dvs. af de nye 500 mio. NOK. Under ordningen gives der støtte til planlægning og udvikling af pilot- og demonstrationsanlæg, til investeringer i udviklings- og pilotfasen og til omkostninger ved testning og driftsstart. Følgende kriterier er vigtige ved udvælgelsen af projekter:

- Projektet skal være samfundsøkonomisk fordelagtigt før tilskuddet og erhvervsøkonomisk fordelagtigt efter tilskuddet. Tilskuddet skal være udløsende for projektets realisering

- Projektet skal have en stor innovationsværdi/nyhedsgrad, og teknologien skal have et betydeligt internationalt vækstpotentiale

- Projektets miljøeffekt skal dokumenteres og kvantificeres i ansøgningen og i slutrapport fra støttemodtager

- Ansøgerens evne til at gennemføre projektet er vigtig, og projektet skal bidrage til at udvikle virksomheden konkurrencekraft

- Pilot- og demonstrationsanlæg skal bygges i Norge

Alt tildelt støtte skal overholde regler i statsstøtteregelværket, gruppefritagelsen for forskning, udvikling og innovation eller gruppefritagelsen for miljøbeskyttelse. Efter gruppefritagelsen kan der gives forskellig støtte afhængig af formål og størrelse af virksomheden.

Arbejdet med miljøteknologi i Norge skal fokusere på, hvor Norge har kompetencer og gode forudsætninger for at lykkes nationalt og internationalt. Prioritering og udvælgelse af indsatsområder skal basere sig på teknologineutrale og transparente kriterier som afspejler målsætninger.

Som et eksempel kan nævnes: energi og transport som vigtige områder i klimapolitikken. Som andre eksempler kan nævnes miljøvenlige transportformer, hvor Samfærdselsdepartementets satser med programmet Transnova, og det får i 2011 tilført 20 mio. NOK, samt havvind, hvor Olje- og Energidepartementets satsning også tilføres 20 mio. NOK.

Et eksempel på en større strategisk satsning er havenergi, hvor regeringen fremlagde en lov om fornybar energi til havs for Stortinget. I forslaget indgår også en national strategi for havbaseret fornybar energi, som opfølgning af Klimaforliget fra 2007. Stortinget vedtog loven den 23. marts 2010 og den trådte i kraft 1. juli 2010.

Den i forslaget beskrevne strategi for havenergi gennemgår teknologiske, forskningsmæssige og andre udfordringer knyttet til fremtidig udbygning af fornybar energi til havs, samt hvordan Olje- og Energidepartementet skal følge op på dette. Strategien følges op gennem det offentlige virkemiddelapparat, især aktiviteterne under Norges Forskningsråd, Enova og Norges vandressources- og elektricitetsdirektorat (NVE).

Af konkrete tiltag til at fremme vedvarende energi til havs kan man nævne følgende:

- I tråd med Klimaforliget har regeringen hævet budgetterne til forsknings- og teknologiudvikling rettet mod vedvarende 
energiproduktion på havet og carbonopsamling og -lagring i perioden 2008-2010 med mere end 600 mio. NOK. Regeringen opretter også to forskningscentre for udnyttelse af havvind

- I 2009 etablerede Enova et demonstrationsprogram for marin vedvarende energi. Denne ordning har støttet Statoils Hywinddemonstrationsprojekt ud for Katmøy, Sways planlagte 10 MWturbine og Hydra Tidals tidevandskraftværk

- Over Olje- og energidepartementets budget bevilges der betydelige midler til havenergi gennem det eksisterende virkemiddelapparat fra forskning til demonstration. I tillæg hertil har regeringen foreslået en øremærket bevilling på 40 mio. NOK knyttet til havvindsatsningen i 2011, hvoraf 20 mio. kommer fra programmet for miljøteknologi

- Som led i strategien for havenergi er der nedsat en direktoratgruppe, som skal vurdere egnede områder til etablering af vindkraft til søs

- Industrigiganten General Electric besluttede i 2010 at etablere et center for teknologiudvikling af havenergi i Oslo samt at udvide produktionen af turbiner i Verdal. Virksomheden ønsker også at teste turbinerne i Norge

- Statoils flydende vindkraftkoncept Hywind blev installeret ud for Katmøy i efteråret 2009 som verdens største flydende vindkraftværk

- Hydra Tidal installerede en prototype af sit tidvandskoncept Morild ved Troms i oktober 2010

- Statkraft og Statoil er blevet tildelt rettigheder til at udvikle og bygge vindkraftprojekter i Storbritanien

- Havsul 1-projektet i Møre og Romsdal modtog koncession i 2009 som det første storskala havvindprojekt i Norge

Ydermere er der etableret en fordelagtig skattefradragsordning, Skattefunn fra 2002/03 til, at virksomheder kan fremme blandt andet udviklingen af miljøteknologi mere fordelagtigt. Med ordningen kan virksomhederne få skattefradrag til forskning og udvikling. Denne ordning vil regeringen vurdere om den også kan omfatte pilot- og demonstrationsanlæg.

Og endelig vil den norske regering vurdere, hvordan Norge skal gennemføre en indsats for teknologiverifisering.

Når man læser denne fremstilling i regeringens strategi om, hvad der er gjort, og hvad der fremover skal gøres, bliver man opmærksom på, at der intet er omtalt om en mulig norsk klimafond eller en bare afvisning af en sådan. Der er endda to uafhængige forslag til en klimafond i Norge, dels en Cicero-rapport og dels et forslag fra Teknologirådet. ${ }^{213}$ Der har i Norge dermed været en række drøftelser af, om man ikke skulle etablere

213 Cicero report 2007:05: Planlagt etablering av Klimafond - diskusjon av formål, anvendelse og effekt, oktober 2007, 18 sider og Teknologirådet: Et norsk fond for klimateknologi, januar 2011, 20 sider. 
en klimafond. Det kan forklares ved, at regeringen har arbejdet med klimaområdet parallelt.

\section{Ad 2) Forskning og kompetenceudvikling}

Under denne overskrift forklarer regeringen, at den vil:

- Styrke miljøteknologi i Norges Forskningsråds ordning for Centeret for forskningsdrevet innovation (SFI)

- Bidrage til at styrke sammenhængen mellem national forskning og udvikling af miljøteknologi og udviklingen i nationale og internationale miljøregelværk

- Vurdere dagens systemer for værdisætning af miljø- og miljøteknologigevinster inden for offentlige virkemidler

- Følge op på satsningen på forskningscenteret for miljøvenlig energi (FME)

Regeringen vil styrke arbejdet med FoU og kompetanceopbygning knyttet til miljøteknologi. Der tilføres 10 mio. NOK i 2011 fra det nye program for miljøteknologi til Norges Forskningsråds ordning Centre for Forskningsdrevet innovation. Regeringen vil derudover satse på flere forskningscentre, som skal støtte udviklingen af et grønnere og mere bæredygtigt norsk erhvervsliv.

Det kan nævnes, at der i 2009 blev oprettet 8 forskningscentre for miljøvenlig energi indenfor vedvarende energi, energieffektivisering og C02-håndtering. Disse centre bidrager til samarbejdet med virksomheder i Norge og internationale aktører. I 2011 blev der oprettet yderligere 3 forskningscentre for miljøvenlig energi. ${ }^{214}$

I Norge er der satset ganske meget på etableringen af forskningscentre. Det er blot meget vanskeligt i den foreliggende litteratur at følge, hvad det enkelte center egentlig skal beskæftige sig med, hvor mange ansatte der er, og hvor mange midler centeret råder over. At have 11 forskningscentre til forskellige aspekter af miljøvenlig energi forekommer som en stor satsning og måske også en for spredt satsning.

\section{Ad 3) Netværk og samarbejde}

Under denne overskrift vil regeringen:

- Vurdere mulighederne for yderligere at styrke stimulering af klynger, netværk, kompetencemiljøer og partnerskaber om miljøteknologi

- Øge dialogen mellem de offentlige virkemiddelaktører og med andre strategiprocesser og organer på området 
Det er regeringens vurdering, at der er store muligheder for udvikling af netværk og samarbejde i Norge, idet man vurderer, at dette område ikke er særlig udviklet.

\section{Ad 4) Miljøreguleringer}

Under denne overskrift forklarer regeringen, at den vil:

- Være omhyggelig med at implementere de internationale rammebetingelser, som stimulerer udvikling og brug af miljøteknologi, herunder påvirkning af EU-regelværk

- Udforme og håndhæve nationale regelværk, herunder miljøafgifter og standarder, som fremmer udvikling og brug af miljøteknologi

- Drage nytte af erfaringer af nye virkemidler, som kan give bedre incitamenter og mere effekt. Et eksempel er NOx-fonden

- Gennemføre en analyse af hvilke områder der har et potentiale til forbedring af norske regler, sådan at reguleringen er i front internationalt og varetager miljøudfordringerne bedre

I handlingsplanen erklæres, at reguleringen af markedet for at nå nationale og internationale miljømål er afgørende for, at miljøteknologi kan vinde frem og blive kommercielt lønsomt. Gode miljøreguleringer er derfor helt centrale i den norske strategi.

NOx-aftalen nævnes som et eksempel en sådan god regulering. Den blev indgået mellem Miljøverndepartementet og 14 erhvervsorganisationer i maj 2008 med udgangspunkt i en afgift på udslip af NOx ved energiproduktion. Erhvervsorganisationerne påtog sig forpligtelser om at reducere de årlige NOxudslip. Samtidig forpligter erhvervsvirksomhederne sig til at indbetale til Erhvervslivets NOx-fond, som kan give tilskud til virksomhederne til at gennemføre reduktionstiltag. De virksomheder, som tilsluttede sig aftalen, blev fritaget for NOx-afgift i årene, 2008-2010. Der er indgået en ny aftale for perioden 2011-2017.

I handlingsplanen nævnes også det arbejde, som Olje- og Energidepartementet har udført for at vurdere virkemidler i den norske klimapolitik. I rapporten vurderes de virkemidler, som anvendes i dagens klimapolitik, og hvad der skal til for at reducere udslippene i Norge i 2020 med 15-17 mio. ton CO2 ækvivalenter. Det har været en intention at finde virkemidler, som er styringseffektive og omkostningseffektive på længere sigt. Udredningen Klimakur blev fremlagt i februar 2010 og bliver en del af grundlaget for regeringens klimaudmelding, som skal fremlægges i Stortinget i 2012. ${ }^{215}$

215 Klimakur 2020: Tiltak og virkemidler for å nå norske klimamål mot 2020, marts 2010, 316 sider. 


\section{Ad 5) Anskaffelser i offentlige og private virksomheder}

Regeringen vil under denne overskrift:

- Styrke det nationale marked for miljøteknologi ved at implementere handlingsplanen for miljø- og samfundsansvar i offentlige anskaffelser

- Vurdere særskilt, hvordan arbejdet med innovative anskaffelser inden for miljøteknologi kan styrkes i offentlige virksomheder

- Arbejde for at virksomheder med særlig store indkøb kan være katalysatorer for innovativ miljøteknologi ved anskaffelser. Dette skal også ses i sammenhæng med arbejdet knyttet til miljøbevidste offentlige anskaffelser

Regeringen er opmærksom på, at hjemmemarkedet som springbræt for nye produkter kan være centralt, når virksomheder bevæger sig ud på internationale markeder. Et overordnet mål med de offentlige anskaffelser er dog, at midlerne skal bruges omkostningseffektivt. Den offentlige sektor køber i dag varer og tjenester for ca. 380 mia. NOK og er dermed en betydelig kunde hos virksomheder. Det er et mål, at miljøbelastningen knyttet til offentlige anskaffelser skal minimeres.

Især på byggeområdet er der blevet gjort en stor indsats, dels i projektet „Fremtidens Byer", som inkluderer de 13 største byer i Norge, dels gennem Enova-programmet rettet mod kommunesektoren og energiområdet.

Regeringens handlingsplan for miljø- og samfundsansvar i offentlige anskaffelser fungerede for perioden $2007-2010,{ }^{216}$ men følges fremdeles op. Det er DIFI (Direktoratet for forvaltning og IKT), som har ansvaret for at implementere handlingsplanen. Den ligger også til grund for en aftale mellem Miljøverndepartementet og Norsk Industri, som omfatter køb af energi- og klimavenlig udstyr i norsk industri og trådte i kraft i juli 2010.

\section{Ad 6) Videreudvikling af vidensgrundlaget for politikken}

Under denne overskrift erklærer regeringen:

- At den vil fremme bedre måling af både indsats og resultater knyttet til miljøteknologi

Ifølge regeringen er der et stort behov for at skabe et bedre vidensgrundlag for indsatsen.

216 Miljøverndepartementet, Fornyings- og Administrationsdepartementet, og Barne- og Ligestillingsdepartementet: Miljø- og samfunnsansvar i offentlige anskaffelser. Handlingsplan 2007-2010, juni 2007, 36 sider. 


\subsection{Den norske regerings program for miljøteknologi}

Regeringen annoncerer, at Programmet for miljøteknologi er blevet iværksat den 1. januar 2011 med en budgetbevilling på 500 mio. NOK over 3 år. Sammen med bevillingerne til miljøteknologiordningen, som forvaltes af Innovasjon Norge, bevilges der dermed over 300 mio. NOK, som er øremærket til miljøteknologi i 2011. Herudover gives der midler til miljøteknologi fra sektorprogrammer, som f.eks. Enova, der forvalter en ordning for ny teknologi om vedvarende energi og energieffektivisering.

Det nye program skal udnytte og supplere eksisterende virkemidler til at fremme udviklingen af miljøteknologi. Tildelingen skal ske med udgangspunkt i projektkvalitet, innovationsgrad og evne til gennemførelse.

Den største del af det første års bevilling (2011) på 117 mio. NOK tilfalder ordningen for miljøteknologi i Innovasjon Norge. Innovasjon Norge er blevet bedt om at følge op på regeringens prioriteringer på det miljøteknologiske område. Fra og med det andet år, dvs. 2012, skal indsatsområderne og virkemidlerne vurderes og videreudvikles. Det skal bl.a. vurderes om dele af bevillingerne kan gives til ordninger, som er etableret i andre dele af virkemiddelapparatet, f.eks. Norges Forskningsråd, Enova, SIVA SF, GIEK, Eksportfinans og Transnova. Andre ordninger nævnes også.

Der oprettes et programråd i tilknytning til Program for Miljøteknologi. Programrådet skal bestå af deltagere fra de mest centrale dele af virkemiddelapparatet. Lederen af rådet skal være uafhængig og have gode faglige kvalifikationer. Programrådet skal vurdere prioriteringer og indsatsområder i programmet og give anbefalinger om ændringer fra og med 2012. Programrådet skal også give anbefalinger om tildelinger til støttepuljer i andre dele af virkemiddelapparatet.

Rådet skal stimulere til dialog og koordinering mellem deltagerne $\mathrm{i}$ programmet og andre virkemiddelaktører. Rådet skal foreslå videreudvikling af regeringens strategi for miljøteknologi.

\section{Bilag 1 til handlingsplanen: Offentlig støtte til teknologiprojekter: om regelværket for statsstøtte.}

I bilag 1 gennemgås statsstøttereglerne for støtte til teknologiprojekter. Det er som udgangspunkt ulovligt at give statsstøtte til erhvervslivet i henhold til EØS-aftalen, som Norge har med EU. Der er dog en række undtagelser, og disse undtagelser gennemgås i bilaget.

Det er meget hjælpsomt i en forståelse af, hvad der gives statsstøtte til, at man gennemgår reglerne i bilaget. 


\section{Bilag 2 til handlingsplanen: Gennemgang af det eksisterende virkemiddelapparat for miljøteknologi. Og Bilag 3 til handlingsplanen: Nærmere om en helhetlig og miljøorientert satsning på teknologiutvikling innen energi og petroleum.}

Dette bilagsafsnit er særdeles nyttigt med information om strategier og tilskudsmidler i det norske virkemiddelapparat. Der kan være et vist overlap i forhold til detaljer nævnt tidligere, men eftersom bilagene har en selvstændig helhedstilgang, er denne model også forsøgt opretholdt her. I dette afsnit omtales dog kun tilskuds- eller støttemidler og ikke f.eks. reguleringer etc. som virkemidler.

\section{Strategier}

Centralt i fastlæggelsen af regeringens politik er Stortingsmeldingerne, hvor der regelmæssigt kommer overordnede udmeldinger om politikområder. Dette sker typisk på et rimeligt overordnet niveau. Ud over hvad der er nævnt ovenfor, kan også nævnes Stortingsmeddelelsen om innovation. ${ }^{217}$ Denne strategis formål er at tilrettelægge national erhvervsudvikling og værdiskabelse, og af relevans for miljøteknologi skal her nævnes, hvordan det kan bidrage til, at Norges miljømålsætninger kan nås.

Man kan også nævne Strategien om FoU og demonstrationsprojekter for 2. generation biobrændstoffer, som fastlægger, hvad Norge skal gøre for at fremme 2. generations biobrændstoffer.

Udredningen om Klimakur er nævnt ovenfor, og der kan yderligere nævnes Klima 21, som er en bredt forankret strategi for klimaforskning. Den følger op på Klimaforliget fra 2008 og fokuserer på 3 prioriterede områder: 1) Klimasystemet, 2) Klimaændringer - konsekvenser og tilpasninger, og 3) Reducerede klimagasudslip. De 2 sidste områder er relevante for en satsning på miljøteknologi.

I denne forbindelse bør man også nævne den nationale strategi for forskning om olie og gas, OG21. Allerede i 2001 bad Olje- og Energidepartementet industrien og forskningsmiljøerne om at udarbejde denne strategi for at kunne lægge den til grund for forskningsprioriteringer knyttet til midler forvaltet af Forskningsrådet. Strategien fremhæver blandt andet miljøvenlig teknologi for olje- og gasproduktion som et prioriteret område.

I 2008 blev Energi21 udformet som en national strategi for energiforskning efter samme model som 0G21. Denne strategi peger på områder, der har speciel interesse for Norge, ved en målsætning om, at Norge skal være en energieksporterende nation og teknologileverandør i fremtiden.

I efteråret 2008 styrkede regeringen egenkapitalen i det statslige energiselskab Statkraft med 14 mia. NOK med det formål, at Statkraft

${ }^{217}$ Stortingsmelding nr. 7 (2008-09). 
skal kunne realisere en investeringsplan til 82 mia. NOK. Denne plan er knyttet til satsning på miljøvenlig vedvarende energi i Norge og internationalt. Det er tanken, at dette skal hjælpe selskabet med at videreudvikle sin position som Europas største producent af vedvarende energi. Selskabet vil kunne gennemføre fremtidsrettede investeringer både inden for vandkraft, vindkraft og fjernvarme.

På det maritime område er der for det strategiske råd for maritim udvikling (MARUT) af det maritime erhvervsliv blevet udarbejdet et forslag til en miljø- og innovationsstrategi på det maritime område frem mod år 2020. Strategien kaldes Maritim 21, og den lægger grundlaget for det videre arbejde på feltet maritim miljøteknologi.

\section{De konkrete tilskudsordninger}

Regeringens bevillinger til erhvervsrelevant forskning og udvikling tildeles gennem Norges Forskningsråd. Mens de virksomhedsrettede virkemidler til innovation i overvejende grad er samlet i Innovasjon Norge. Det norske virkemiddelsystem for tildeling af økonomiske midler består af store tilskudsordninger med en åben konkurrence. Her konkurrerer miljøteknologi på lige fod med andre projekter. På nogle områder anvendes også øremærkning af midler direkte til miljøteknologi.

Norges Forskningsråd fordeler i 2011 ca. 7 mia. NOK til alle forskningsformål. Totalbevillingerne over årene 2008-2010 til energi og miljø er opgjort til 1,3 mia. NOK. Det kan nævnes, at budgetterne til forskning i vedvarende energi og carbonopsamling og -lagring blev hævet med 600 mio. NOK i perioden fra 2008-2011. Disse forskningsprogrammer dækker hele værdikæden fra forskning til pilotprojekter i mindre skala. Man kan nævne flere af programmerne under Norges Forskningsråd:

- Renergi, som skal fremme løsninger på energiområdet inden for produktion og forbrug. Programmet modtog i 2009255 mio. NOK, og i 2010 og i 2011 henholdsvis 363 og 355 mio. NOK

- Climit, som støtter CCS (carbon capture and storage) forsknings- og demonstrationsprojekter i mindre skala. Dette program fik tilført 181 og 176 mio. NOK i henholdsvis 2010 og 2011

- Petromaks, der støtter forskning inden for oljesektoren med grundforskning, kompetenceopbygning og anvendt forskning

- Brugerstyret innovationsarena (BIA), som har en stor andel miljøteknologi, bl.a. i forskning af genanvendelse og affaldshåndtering, nye målemetoder til farlige gasser, udvikling af mere miljøvenlige produkter eller nye processer til fremstilling af materialer med væsentligt lavere udslip

Norges Forskningsråd støtter også de tidligere nævnte 11 forskningscentre, som kan få en levetid på op til 8 år. Disse centre får 125 mio. NOK 
pr. år og det samme beløb fra industrien oven en 8 års periode, hvilket bliver en udgiftspost på 2 mia. NOK eller ca. 2.000 årsværk. ${ }^{218}$

Innovasjon Norge fordeler ca. 10 mia. NOK årligt til forskellige formål til fordel for norsk erhvervsliv. Innovasjon Norge ejes af Nærings- og Handelsdepartmentet (NHD) med $51 \%$ og af Fylkeskommunerne med $49 \%$. Aktiviteterne omfatter tilbud om finansiering, kompetence, rådgivning, netværk og profilering. Midlet er tildeling af tilskud.

De senere år har Innovasjon Norge brugt betydelige midler på miljøprojekter. I 2010 gik 1,2 mia. NOK til projekter, som blev vurderet som miljørettede. I de fleste projekter er der udviklet eller implementeret et miljøprodukt eller en miljøtjeneste. Som nævnt ovenfor havde Innovasjon Norges miljøteknologiordning i 2010140 mio. NOK, og der bevilges igen 140 mio. NOK i 2011. Ordningen får så yderligere tildelt 117 mio. NOK i 2011.219

Energi- og miljøsatsningen i Innovasjon Norge omfatter bl.a. følgende områder:

- Energisystemet og energieffektiviseringen

- Klimavenlig energi (fra vand, vind, biomasse, affald, spildvarme, hav og sol)

- Klimavenlig transport

- Rent vand og ren luft

- Binding og lagring af $\mathrm{CO} 2$

Centralt i Innovasjons Norges aktiviteter kan man fremhæve tilskud til demonstrationsanlæg.

Under Miljøteknologiordningen blev der i 2010 givet tilskud til en række spændende projekter, hvoraf følgende kan nævnes. ${ }^{220}$

Der blev givet 58 mio. NOK til Borregaard til produktion af bioetanol ved brug af affaldsstoffer fra landbrug og skovbrug. Borregaard kan med den nye teknologi nedbryde cellulose til sukker og opnå, at en stor del af råvaren bliver til sprit.

Weyland har fået 20 mio. NOK til et pilotanlæg, som kan gøre biomasse til bioetanol. Teknologien skal på sigt blive konkurrencedygtig med 1. generations bioetanol i USA og Brasilien.

Der er blevet givet 15 mio. NOK til CMR-selskaber, CMR Prototech og Zeg Power. CMR Prototech har testet brændselscelledrift på en kommerciel færge i Bergen og Zeg Power konverterer biomasse til hydrogen og elektricitet til transportformål.

\footnotetext{
218 Menon Business Economics: Miljøteknologi i Norge, november 2011, 26 sider.

219 Trond Giske: overheads om tilskudsaktiviteter i Innovasjon Norge, 30. marts 2011.

${ }^{220}$ Innovasjon Norges hjemmeside: Miljøteknologiordningen 2010 - prosjekteksempler, 2 sider. Miljøtekno-

logiordningen har fået en bedre hjemmeside.
} 
Enova er blevet oprettet i 2002 af Olje- og Energidepartementet for at styrke arbejdet med en miljøvenlig omlægning af energiforbrug og produktion i Norge. Enova administrerer 3 programmer til demonstrationsprojekter:

- Et program for innovative energiløsninger rettet mod verifisering af ny teknologi. Der kan søges om støtte til ny teknologi, løsninger og produkter ved verifisering i pilotanlæg

- Et program for ny teknologi til at støtte udviklingen af energiteknologi til energibesparelser eller produktion af vedvarende energi. Demonstrationsprojekter i Norge støttes med ordningen. Der støttes primært større projekter

- Et program for vedvarende marin kraftproduktion. Demonstrationsprojekter til vedvarende marin energiproduktion støttes

Siden starten har Enova bevilget ca. 415 mio. NOK til demonstration af ny energiteknologi. I de seneste år har Enova satset mere, og i 2010 blev der bevilget 201 mio. NOK til 5 projekter med ny energiteknologier.

Indenfor området vedvarende varmeenergi er der i 2010 støttet 160 projekter med et beløb på i alt 541 mio. NOK.

Indenfor området vedvarende kraft er der i 2010 støttet 4 vindkraftprojekter med et totalbeløb på 978 mio. NOK.

Indenfor området industri blev der i 2010 støttet 30 projekter med i alt 298 mio. NOK, så industrien kan realisere energieffektivitet og -omlægning, så norsk industri kan blive den mest energieffektive i verden. ${ }^{221}$

Som en direkte opfølgning på Klimaforliget blev Transnova etableret $\mathrm{i}$ 2009 som et 3-årigt prøveprojekt under Vejdirektoratet. Programmet giver tilskud til projekter, som bidrager til hurtigere implementering af en mere miljøvenlig transportteknologi og transportpraksis. Der er bevilget 50 mio. NOK hvert år i 2009 og 2010, mens der i 2011 er 73 mio. NOK til rådighed, hvoraf de 20 mio. NOK er bevilget fra Programmet for miljøteknologi. I 2009 etablerede Transnova en støtteordning for opladningssteder til elbiler, hvilket har resulteret i 1.800 opladningssteder.

Under Transnova er en anden støtteordning til indfasning af alternative brændstoffer også etableret i 2009, og der er givet støtte til projekter inden for brændstoffer, hydrogen og elektricitet.

Transnova har endvidere andre aktiviteter som miljøvenlige transportformer, reduceret transport etc.

I Bilag 3 til handlingsplanen gennemgås forskning og demonstration inden for energi- og petroleumssektoren. Dette afsnit er til dels en gen- 
tagelse og yderligere detaljering af strategidelene og virkemiddelapparatet under Bilag 2, og er allerede nævnt ovenfor.

\subsection{Norske eksempler med international succes}

Dette afsnit vil beskrive eksempler på norske miljøteknologiområder med international succes, som omtalt fra norsk side. Det vil sige, at der er tale om en norsk opfattelse af, hvad der har været succesrigt. Dette er givetvis korrekt, men der er ingen sammenligning.

En publikation udmærker sig i en sådan beskrivelse af konkrete eksempler på norske miljøteknologier. ${ }^{222}$ Notatet er en guldgrube af detaljer om norsk miljøteknologi. Der er mange firmaoplysninger og i mindre grad beskrivelse, så læsningen forudsætter en vis viden om miljøteknologi etc.

Nogle af erfaringer i publikationen er fremhævet og går på at:

- Norge har udviklet miljøteknologi i forbindelse med traditionelle norske industrier som træforædling, ferrosilisium, aluminium, kunstgødning, skibsfart og petroleum

- Lave elektricitetspriser pga. billig vandkraft har givet dårlige vilkår for udvikling for fornybare energikilder. Dog har silisiumkompetence betydet, at Norge står stærkt i solcelleproduktion. Man kan også nævne styrke i forbindelse med el-biler, hydrogen og naturgas, kuldioxidfangst og -lagring

- Norske miljøkrav har givet flere teknologier indenfor vand- og afløbsrensning, samt inden for flaskepantautomater

- Der ses en tendens til, at store internationale koncerner overtager efter udviklingsperioden. Med det norske omkostningsniveau ses mere norsk styrke på teknologiudvikling og teknologitjenester end i produktionen

Publikationen nævner også fiaskoer for udvikling i Norge som varmepumper og affaldsforbrænding, hvor man fra norsk side har satset, men ikke særlig succesrigt.

På en måde er denne publikation helt unik i sin mængde af informationer om enkelte teknologier og firmaer. Man kunne ønske sig, at der også for de andre nordiske lande var sådanne publikationer tilstede.

Der er i Norge klare tegn på, at solenergi, rensning af afgasning fra industri og transport, optisk affaldssortering, rensning af ballastvand, samt overvågning af miljøet har udviklet sig ved at fokusere internatio-

222 Øyvind Lone: Norsk miljøteknologi: Noen eksempler og erfaringer, maj 2011, 90 sider. 
nalt. Dette er også ved at ske inden for vandkraft, distribution og handel med kraft, vindkraft og miljørådgivning. Omvendt er affaldshåndtering, bioenergi, energieffektivisering og anden vedvarende energi mest præget af hjemmemarkedet.

Som nævnt ovenfor har en rapport fra Menon 5 historiske eksempler på norske miljøteknologier med international succes. ${ }^{223}$

De nævnes nedenfor.

\section{Optisk affaldsortering: Titech}

Fra norsk offentlig forskningsside blev der gennem 70'erne og 80'erne investeret i infrarød optik. Denne teknologi blev udviklet med anvendelse af norske offentlige midler til at genkende materialer eller affald, og dette blev videreudviklet til brug for drikkeemballage. I dag har Titech mere end 2000 produktionssteder i 25 lande til at separere rene fraktioner til materiale og energigenanvendelse.

\section{Miljøvenlig skibsmaling: Jotun Coating}

I år 2000 lancerede firmaet Jotun et tinfrit bundbehandlingsstof SeaQuantum, som både er tinfrit, giver en effektiv beskyttelse mod begroning og er selvpolerende. Koncernen Jotun har i dag 40 fabrikker i 36 lande. Jotun har som en af 5 store internationale aktører omkring $80 \%$ af verdensmarkedet.

\section{Photovoltaisk solcelleenergi: bl.a. Renewable Energy Cooperation (REC)}

Noget overraskende er norsk solcelleteknologi en del af den ledende gruppe firmaer i verden på solcelleområdet. Dette skyldes rigelig tilgang af råvarer, bl.a. silisium og udnyttelse af effektiv teknologi. Solcelleindustrien i Norge har 20 virksomheder, hvor REC er den største.

Integrerede operationer: Norske systemleverancer.

Begrebet Integrerede operationer er en række dataløsninger som bidrager til mere effektiv informationstilgang og -behandling med mulighed for fjernstyring af forskellige typer af operationer. Der kan være sensorteknologi, dataintegration, dynamisk positionering, modellering, visualisering etc. involveret. Især kan dette bruges til miljøfunktioner til havs i olieindustrien.

\section{Miljøovervågning til havs: Fugro Oceanor og Aanderaa Data}

Fugro Oceanor og Aanderaa Data er ledende internationalt, når det gælder udvikling og produktion af miljøovervågningsteknologi til havs. Et af pro- 
dukterne er en bøje til forskellige målinger til havs, kaldet Seawatch. I 2008 havde Fugro Oceanor en omsætning på 109 mio. NOK og 50 ansatte.

\subsection{Arbejdet med efterspørgselssiden i Norge}

I Norge arbejdes der med efterspørgselssiden, både gennem reguleringer og ved offentlige anskaffelser. Der arbejdes med at fremme en bedre kobling mellem tilbudsvirkemidlerne og efterspørgselsvirkemidlerne. Der henvises også til afsnittet om miljøregulering i den nye norske strategi ovenfor.

Regeringen nævner i sin strategi fra 2011 miljøreguleringer, som et af de indsatsområder, der skal satses på. Gode miljøreguleringer anses for centrale i den norske strategi. NOx-aftalen nævnes som en sådan god regulering. Og klimaområdet nævnes som et område, hvor det er oplagt at fremme reguleringer.

Regeringen nævner også i sin strategi offentlige anskaffelser, som et instrument til at fremme efterspørgslen. Private anskaffelser er allerede $i$ et vist omfang koblet til arbejdet med de offentlige anskaffelser. På dette område har den norske institution for bæredygtig forbrug og produktion, GRIP længe arbejdet med at fremme instrumenter og retningslinier. ${ }^{224}$

Man kan sige om dette område, at der i Norge er klare intentioner om at fremme efterspørgselssiden. Man er opmærksom på vigtigheden af at påvirke efterspørgslen ved fremme af markedet for miljøteknologi. Det er imidlertid vanskeligt at finde materiale som effektvurderer, hvad der reelt sker på området.

\subsection{Konklusion på Norges aktiviteter}

Der har i Norge ikke været så megen fokus på antallet af virksomheder, som man kan placere i miljøteknologisektoren, på trods af en stor interesse for at fremme miljøteknologi. Menons notat om miljøteknologi i Norge giver det bedste bud. Her er konklusionen, at der er 300 virksomheder og en omsætning på 18 mia. NOK i 2010, samt en totalbeskæftigelse på 6.000 ansatte i sektoren. Menon vurderer, at der er tale om en konservativ talmæssig vurdering. Det er på denne baggrund forholdsvist nemt at konkludere, at man bør opbygge mere viden om antallet af virksomheder, hvad de laver, og evt. hvordan de kan få hjælp fra det offentli-

224 Norway's National road map, Environmental Technologies (Follow-up of the EU Environmental Technologies Action Plan, ETAP), 2006, 14 sider. 
ge. En statslig aktør bør tilslutte sig dette arbejde med statistik indenfor miljøteknologi. Opgørelserne bør være årlige.

Menon har også lavet en vurdering af eksporten af miljøteknologi i Norge. Denne vurdering konkluderer, at eksporten i 2009 var på 6,5 mia. NOK og i 2010 var den på 6,7 mia. DKK Opgørelsen bygger på 114 selskaber og kan meget vel være underestimeret. Der bør være en årlig vurdering af eksporten, som kan vise noget om udvikling af sektoren især en international styrke. Og selvom det er prisværdigt, at Menon nærmest er den eneste aktør i Norge, som interesserer sig herfor, bør en statslig aktør også tilslutte sig arbejdet med eksportstatistik.

En virkelig god introduktion til emnet om miljøteknologi i Norge er Teknologirådets vurdering af området fra 2005. Denne rapport giver faktisk en ret god og rimelig uafhængig vurdering af emnet. Man må sige, at en sådan vurdering er guld værd for et land, som hermed får mulighed for at reflektere, om man vil gøre noget ved indsatsen eller ikke. På denne måde har rapporten uden tvivl haft stor positiv effekt på statens ageren på området i Norge. Problemet er naturligvis, at publikationen er forældet, eftersom der er sket ganske meget i Norge efter denne tid.

I flere Stortingsmeldinger forklarer den norske regering, at den vil gøre Norge til et foregangsland for miljøteknologi. Dette fører dog ikke i første omgang til en egentlig formuleret strategi fra regeringen, men til en åbning for Statens Forurensningstilsyn, Innovasjon Norge og Norges Forskningsråd til at arbejde med temaet og drive det fremad. I 2007 udgiver de 3 institutioner et forslag til en samarbejdsmodel for fremme af miljøteknologi. Og man fornemmer, at de 3 institutioner fremover er ret aktive på området. Denne periode fra 2004-2007 kan man passende kalde for perioden med miljøteknologiprojektet under Statens Forurensningstilsyn.

I 2008 oprettes et strategisk råd for miljøteknologi, som følger arbejdet. Dette arbejde må siges primært at bestå af publikationer, som ud fra forskellige vinkler belyser Norges muligheder i en miljøteknologisk sammenhæng. Man analyserer især, hvad andre lande har gjort, og der er ganske meget materiale om, hvad disse lande har gjort. Rapporterne har også generelt et højt kvalitetsniveau og omhandler ofte teoretisk materiale, hvilket naturligvis er interessant. Det kan undre, at man ikke i Norge i større grad har udformet mere officielle strategier på baggrund af det udmærkede rapportmateriale. Såfremt dette er sket, synes det ikke at være nedfældet og slet ikke formidlet ud til offentligheden. Denne periode fra 2008-2011 kan man passende kalde for perioden med Det Strategiske Råd for Miljøteknologi.

Afgørende for indsatsen i Norge er regeringens strategi for miljøteknologi i 2011. Denne strategi må siges at bygge på det grundlæggende arbejde, som tidligere er blevet lavet i Norge. Strategien har en meget kvalificeret udformning med fokus på 6 centrale dimensioner, som gennemgås detaljeret. Der oprettes endvidere et program for miljøteknologi med en ekstra programbevilling på 500 mio. NOK over 3 år, primært 
placeret i Innovasjon Norge. Strategien har også nogle interessante bilag, som detaljeret beskriver forskellige aktiviteter. Med denne strategi får Norge en længe efterspurgt statslig strategi for miljøteknologi, og man må sige, at Norge går ind i en ny fase for arbejdet med miljøteknologi.

Når man ser bort fra strategien, mangler der ganske meget arbejde for at løfte en ambition om at fremme miljøteknologi i Norge. Man bliver nødt til at få mere styr på, hvem der er virksomhedsaktørerne, og f.eks. hvor meget de eksporterer. Man bliver nødt til at beskrive flere detaljer om teknologiområder og indsatser. Det er muligt, at disse er kendte i snævre kredse, men det mangler i den grad til at løfte området mere offentligt, så der kan komme overensstemmelse mellem politikudmeldinger og virkemidler eller indsats. En del af denne beskrivelse bør også være evalueringer af, hvad der har foregået på tilskudssiden, og hvad effekterne har været. 



\section{Sveriges indsats for miljøteknik 2004-2011}

I Sverige anvendes i udpræget grad begrebet miljøteknik for miljøeffektiv teknologi. Derfor vil miljøteknik blive anvendt i afsnittet om Sverige.

\subsection{Svensk erhvervslivs aktiviteter inden for miljøteknik}

Swentec, Sveriges miljøteknikråd som blev oprettet i 2005, fik til opgave af regeringen at udvikle en effektiv struktur til at fremme vækst for svensk miljøteknologi. ${ }^{225}$ Som en oversigt over svensk erhvervslivs aktiviteter inden for miljøteknik har Swentec sammen med SCB (Statistiska centralbyråen) arbejdet med en delpopulation af SCBs database om miljøvirksomheder. I publikationen Svensk miljøteknik i siffror 2009 er der lavet en tidsserie fra 2003 til og med 2009 med information om virksomheder og eksport. ${ }^{226}$

SCB har siden 1998 via miljøregnskaberne for virksomheder udviklet en database, som indeholder miljøteknikvirksomheder. Allerede i 2000 udgav SCB en rapport om virksomhederne i miljøtekniksektoren. ${ }^{227}$

I publikationen miljøteknik i siffror 2009 defineres miljøteknik ikke som en selvstændig branche, men snarere en sektor som skærer igennem flere brancher. Det præciseres også, at der pågår et fortløbende arbejde med at forbedre og opdatere grundlaget for den svenske miljøteknikstatistik. Statistikken omfatter virksomheder, hvis hovedområde er indenfor miljøteknik, men også virksomheder, som har en delmængde af sin produktion og sine tjenester inden for miljøteknik, og som samtidig ikke er virksomhedens hovedområde. SCB forsøger at lægge en miljøandel på disse sidste virksomheder for at kunne vægte deres miljøarbejde.

I Sverige anvendes begrebet miljöteknik, som er al teknologi, der direkte eller indirekte bidrager til et bedre miljø. Det omfatter ikke kun teknik eller teknologi og tekniske systemer, men også helhedstænkning i

225 Se nedenfor under afsnittet om Swentec.

226 Swentec/SCB: Svensk Miljöteknik i siffror 2009, Statistik och analys för den svenska miljötekniksektorn, 11 sider. 227 SCB: Miljöräkenskaper. The environment industry in Sweden 1999, rapport 2000:1, 48 sider. 
form af hele livscyklussen. Dermed er begrebet på linje med EU's ETAP begreb og OECDs begreb, jf. ovenfor under indledningen.

Den svenske anvendelse af miljøteknik omfatter følgende områder:

- Affaldshåndtering og genvinding

- Bioenergi

- Støj

- Bæredygtigt byggeri og energieffektivisering

- Konsulent- og uddannelsestjenester og Forskning og Udvikling

- Luftrensning

- Jordrensning

- Vandrensning

- Vind, sol og vandkraft

- Transport og fornybare brændsler

Virksomhedspopulationen i Sverige opgøres samlet til ca. 6.500 virksomheder med en omsætning på 119 mia. SEK i 2009. I denne virksomhedsopgørelse er en række virksomheder dog ikke medtaget, f.eks. bæredygtigt jordbrug og fiskeri, økoturisme, kommunale virksomheder inden for vandforsyning og splidevandsafledning, kommunale kraft- og varmeproducenter. Det viser sig, at omsætningen faldt fra 2008 til 2009 med 11,9 \% fra 135 mia. SEK til 119 mia. SEK. Beskæftigelsen faldt dog kun ganske lidt til 41.420 ansatte. Af de ganske mange virksomheder er de 5.500 opgjort til at have mellem 1-10 ansatte, hvilket er 84,4 \% af virksomheder, mens 72 virksomheder har over 250 ansatte og udgør 1,1 $\%$ af virksomhederne.

I det lille skrift om statistik vurderes også den regionale fordeling $\mathrm{i}$ Sverige i mellem de forskellige län. Virksomhederne, som beskæftiger sig med miljøteknik, findes primært i storbyområderne. Dette forekommer dog ikke særlig interessant i sammenhæng med temaet for den foreliggende publikation.

Man må konkludere, at der er stor konsensus om opgørelsen af data i den svenske miljøtekniksektor. Kun Swentec og SCB arbejder med temaet og deres tal medtages i andre rapporter. Ydermere må man også konstatere, at der arbejdes seriøst med at forbedre statistikken i Sverige. Antallet af virksomheder, som er med i populationen for miljøteknik, nemlig 6.500, forekommer forholdsvist stort, også for et land af Sveriges størrelse. Der er ganske vist tale om et meget stort antal små firmaer eller enkeltmandsfirmaer, og dette slører nok billedet ganske meget for, hvilke virksomheder der giver sektoren sine hovedaktiviteter. Når man nu i Sverige er så langt fremme med en statistik, burde man også have styrke til at gå lidt længere i dybden med antal og lave en differentiering af virksomhederne. Så kan man givetvis bedre hjælpe med at dosere styringsmidlerne til bedre brug i virksomhederne. 


\subsubsection{Eksport af svensk miljøteknik}

Bemærkelsesværdigt øgedes eksporten med 4,8 \% fra 2008 til 2009 fra 37 mia. SEK til næsten 39 mia. SEK., selvom omsætningen faldt med næsten $12 \%$ Et tidligere tal viste 31,6 mia. SEK for vareeksport, så i tallet på $39(38,6)$ er også tjenester lagt til. Øgningen af eksporten fra 37 til 39 må tolkes som, at eksportmarkedet er blevet mere vigtigt end indenrigsomsætningen. Den største eksportsektor er affaldshåndtering og genvinding med knap 10 mia. SEK fulgt af bæredygtig byggeri og energieffektivisering med 8,5 mia. SEK, sol, vind og vandkraft med 7,3 mia. SEK, vand med næsten 6 mia. SEK og bioenergi med 4 mia. SEK. Det vigtigste eksportmarked er Tyskland med 6 mia. SEK eller $16 \%$ af eksporten, fulgt af 3,5 mia. til Norge, 2,7 til Kina, 2,5 til USA og 2,1 til Danmark. For året 2010 viser det sig, at Kina er blevet det næstvigtigste eksportmarked for miljøteknik.

Samlet set udgør eksporten af miljøteknik i Sverige, varer og tjenester, kun $2 \%$ af den samlede eksport af varer og tjenester, hvilket jo ikke er så meget.

Det virker som om man i Sverige har virkelig godt styr på eksporttallene, som en vigtig parameter for fremgang i miljøtekniksektoren og international formåen. Dette er meget positivt, og gør det naturligvis muligt i fremtiden at følge med i sektorens udvikling via eksportparameteren.

\subsection{Vurderinger og initiativer for miljøteknik i Sverige}

Dette afsnit forsøger, efter en kort introduktion til centrale aktører, at give et tilbageblik over, hvad der er sket i Sverige vedr. miljøteknik i perioden. Dermed er der tale om en kronologisk gennemgang af aktiviteter baseret på tilgængelige rapporter.

\section{Centrale aktører i Sverige på myndighedsplan}

I regeringen er der flere departementer, som har ansvaret for forskellige spørgsmål og på forskellig måde berører miljøområdet og dermed miljøteknik. Man kan nævne Näringsdepartementet som har ansvaret for erhvervsliv, Miljödepartementet, som har ansvaret for reguleringen, Jordbrugsdepartementet, som har ansvaret for jordbrugserhvervet og fødevarer, samt Utbildingsdepartementet, som har ansvaret for finansiering af forskning. Ved lovgivning, primært rettet mod forskellige udslip til luft, vand og jord, fastlægges rammerne for de vilkår, som virksomheder skal opfylde og som har stor betydning for miljøtekniske virksomheder. En række styrelser og andre myndigheder forvalter midler til støtte eller tilskud. De nævnes umiddelbart herefter.

NUTEK er eller snarere var den svenske styrelse for erhvervsudvikling, idet den er nedlagt og erstattet af Tillväxtverket, og havde til formål 
at fremme vækst og velstand. NUTEK har gennemført en række studier med miljø og erhvervsindhold.

Swentec var i perioden 2005-2010 Sverige miljøteknikråd, se særskilt afsnit nedenfor.

Naturvårdsverket er Sveriges centrale miljømyndighed og er ansvarlig for miljøreguleringen i Sverige. Naturvårdsværket administrerer også en række tilskudsordninger til fremme af miljøteknik. Man kan nævne, KLIMP (klimainvesteringsprogrammet) og FLIPP (Forudsætninger for livscyklushensyn i integreret produktpolitik).

Vägverket, Jordbrugsverket, Boverket, Banverket og Skovstyrelsen er de nationale myndigheder på hvert sit område, og de har visse midler til rådighed på deres respektive områder.

VINNOVA er Sveriges innovationsstyrelse og beskæftiger sig med innovation og vækst. VINNOVA har lavet en række analyser af forskning og miljøteknik og finansierer forskning på området.

Formas er forskningsrådet for miljø, jordbrugserhverv og samfundsbebyggelse.

Energimyndigheten er ansvarlig for energiområdet og har et omfattende program til forskning og teknikudvikling på energiområdet, bl.a. fornybar energi.

Man kan også nævne Exportrådet og SIDA, den svenske bistandsstyrelse, samt en række øvrige forskningsaktører.

\section{Et nationalt center for miljøteknik}

Den svenske regering bestilte i februar 2004 et forslag til en organisation om et nationalt center for miljødrevet erhvervsudvikling og miljøteknikeksport. ${ }^{228}$ I beslutningen forklares, at formålet med at etablere et center skal være at opnå en forbedret koordination og styrkelse af statens indsats på miljøteknikområdet. I august 2004 blev betænkningen om et nyt nationalt center afleveret. ${ }^{229}$ NUTEK, den svenske styrelse for erhvervsudvikling, havde dog også tidligere i 2003 udformet forslag til styrkelse af miljøteknikområdet. ${ }^{230}$ Der er en klar linje fra dette eller disse forslag og til udformningen af betænkningen.

Betænkningen har gennemgået området med en række analyser om EU's strategi/ETAP, verdensmarkedet, eksport, det svenske marked etc. Disse analyser vises i bilagsform i betænkningen. Den centrale del af betænkningen beskæftiger sig med selve forslaget til et nyt nationalt center.

\footnotetext{
${ }_{228}$ Kommittédirektiv fra Näringsdepartementet: Organisation av ett nationellt centrum för miljödriven näringsutveckling och miljöteknikexport, Dir. 2004:25, 5 sider.

${ }^{229}$ Swentec AB - för en nationell kraftsamling på svensk miljöteknik, SOU 2004:84, 155 sider.

230 NUTEK: Nationellt centrum för miljödriven näringslivsutveckling och miljöteknikexport - ett förslag från NUTEK, april 2003, og NUTEK: Nationell kraftsamling för miljödriven näringslivsutveckling - ett förslag från NUTEK, november 2003.
} 
Betænkningen foreslår følgende opgaver for centret:

- Udvikle netværk samt styrke eksisterende netværk. Udvikle kontakter og fremme samarbejdet mellem nationale, regionale og lokale initiativer på miljøteknikområdet

- Virke for at aktiviteter som udføres af interessenterne skal koordineres bedre, skabe synergier og fremme en national samling af ressourcer. Virke for at samarbejdsprojekter i hele værdikæden initieres, og at systemløsninger indenfor nye teknikområder kan skabes

- Skabe kontakter og fremme samarbejdet mellem markedets forskellige aktører, dvs. virksomheder, forskere, finansfolk, bistandsorganer, myndigheder og organisationer, udlandsorganisationer m.fl.

- Identificere og kommunikere Sveriges konkurrencefordele inden for miljøteknikken ved i samarbejde med interessenter at kortlægge og formulere „fokusområder“. Analysearbejdet bør ske i samarbejde med relevante myndigheder (NUTEK, VINNOVA m.fl.) og organisationer (Exportrådet, regionale og andre netværk), virksomheder og forskere inkl. miljøadministrationen

- Indsamle, analysere og sprede væsentlig information og viden langs hele værdikæden - fra forskning til marked og fra marked til øvrige dele af værdikæden

- Styrke det internationale vidensudbytte og her at identificere behov og mulige indsatsområder, samt at formidle dette til regeringen

- Udgøre et kontaktpunkt indenfor miljøteknikområdet for udenlandske beslutningstagere, som ønsker vidensoverføring eller teknologibytte med Sverige samt eksport fra Sverige

- Videreudvikle mulige finansieringsløsninger for miljøteknikudvikling, inkl. risikokapitalforsyning

- Have et overblik over Sveriges internationale forbindelser på miljøteknikområdet, samt virke for at Sverige fortsat skal være ledende og politisk drive processer for at fremme miljøteknik ved at rådgive og bistå regeringen

- Bistå regeringen med praktiske opgaver i forbindelse med officielle udenlandske delegationsbesøg i Sverige og ligeledes også ved udenlandske rejser for officielle delegationer fra Sverige

På denne baggrund besluttede den svenske regering i april 2005 at etablere et råd for miljøteknik, miljødrevet erhvervsudvikling og miljøteknikeksport. Rådet bliver kaldt Sveriges Miljøteknikråd, Swentec (Swedish Environmental Technology Council). Se afsnittet nedenfor om Swentec. 


\section{Forskningsstrategi for miljøteknik}

Forskningsrådet Formas og VINNOVA udarbejdede på opdrag af regeringen en fælles forskningsstrategi for miljøteknik til udgivelse i juli 2007. ${ }^{231}$

Rapporten konkluderer, at miljøteknisk forskning skal løftes og synliggøres i Formas og VINNOVAs virksomhedsområde. Endvidere bør man i arbejdet være mere opmærksomme på små og mellemstore (SMF) virksomheders behov i denne sammenhæng.

I det svenske innovationssystem har man identificeret 6 styrkeområder:

- Bæredygtig samfundsbebyggelse i form af bæredygtige bygninger og renoveringer og bæredygtige byer, samt en række konkrete teknikker til at fremme miljøteknik på disse områder

- Bæredygtige transporter i form af kollektiv transport og konkrete teknikker som motorer, brændstoffer etc.

- Miljøbeskyttelsesteknik til rensning af vand og luft, samt fremme af affaldsbehandling

- Anvendelse af biologiske ressourcer på energiområdet, vedvarende råvarer etc.

- Lette og avancerede materialer

- Energiformer til mere miljøvenlig produktion

En række konkrete forslag foreslås som f.eks.: bedre tværdisciplinær fokus, bedre finansieringsfokus, bedre koordination og samarbejde etc.

Desuden består rapporten af en række afsnit om aktiviteter i andre lande, bl.a. Japan.

På en måde forekommer denne rapport ikke så interessant. Regeringen har bedt om et forslag og får en række forslag, som ikke er helt så konkrete, som man sikkert kunne tænke sig. Det virker som om, at man har gjort det bedst mulige i en situation, hvor regeringen bad om noget konkret.

\section{Svensk Miljøteknik}

I juni 2008 udgiver ITPS en publikation om Svensk miljøteknik, som er et ganske omfattende værk. ${ }^{232}$ Publikationen gennemgår en række centrale spørgsmål om miljøteknik som: hvorfor fremme miljøteknik?, teori, markedsforhold, politik på området, aktører etc. Hertil er der et stort afsnit om europæisk politik, Tyskland og Danmark, hvor det beskrives, hvad der sker. Der er ligeledes et afsnit om USA og et om Asien.

231 VINNOVA: Forskningsstrategi för miljöteknik. Redovisning av regeringsuppdrag till Formas og VINNOVA, juli 2007, 245 sider.

232 ITPS, Instituttet för tillväxtpolitiska studier: Svensk miljöteknik, En kartläggning av aktörer, marknader och konkurrenter, juni 2008, 123 sider. 
Nogle af hovedkonklusionerne er følgende:

- Miljøteknikvirksomheder er spredt i alle dele af erhvervslivet og udgør en meget heterogen gruppe af virksomheder. Sektoren omfatter videns- og forskningsintensive virksomheder, rådgivningsvirksomheder, samt traditionelle industrivirksomheder

- Der råder en potentiel målkonflikt mellem vækst i miljøteknikvirksomheder og i økonomien som helhed. Anvendelse af styringsinstrumenter fører til øgede omkostninger i nogle dele af erhvervslivet, især på kort og mellemlangt sigte

- Eksportpotentialet er meget stort. Efterspørgslen efter vandrensning, bæredygtig infrastruktur og bæredygtige byer er øget dramatisk

Det er en interessant hovedkonklusion, at der eksisterer en målkonflikt mellem vækst i miljøteknikvirksomheder og i økonomien som helhed. Det er et argument, som ikke så ofte bliver fremført i debatten om at fremme miljøteknik. Som oftest fremhæver analytikere fordelene ved at fremme miljøteknik og ikke så ofte, at det undertiden fører til omkostninger for andre aktører. Denne fokus på målkonflikten eller interesseforskelle kan forklares ved tidspunktet for analysen, hvor der stadig ofte anvendes pro et contra argumenter for at fremme miljøteknik.

\subsubsection{Swentec}

I april 2005 blev Swentec etableret under styrelsen for erhvervsudvikling, NUTEK.

Swentec har eksisteret i perioden 2005-2010. I Kommittédirektiv 2008:31 blev der i marts 2008 fastlagt en række opgaver, som Swentec skulle gennemføre i perioden fra april 2008 til årets udgang $2010 .^{233}$ Disse opgaver fulgte i stor grad de ovenfor nævnte opgaver, som betænkningen nævnte, og som er refereret ovenfor. Som noget særligt blev Swentec omorganiseret til en delegation, som det hedder på svensk, i april 2008 og blev placeret direkte i tilknytning til Näringsdepartementet.

Hovedopgaven er at skabe en effektiv statslig struktur for at styrke de svenske miljøteknikvirksomheder. Delegationen skal udarbejde grundlaget for regeringens indsats på området, samt på forskellige måder støtte miljøtekniksektoren i Sverige og de svenske virksomheder på området. Den skal skabe et overblik over miljøteknikbranchens forudsætninger og behov, videreformidle denne viden til myndigheder og andre aktører, medvirke til at modtage delegationer fra udlandet, bearbejde relevant statistik, fremme en koordinering af statens indsatser på

${ }^{233}$ Kommittédirektiv 2008:31 Sverige miljöteknikråd - en delegation för miljöteknik, 3 sider. 
området, samt fremme koordinering med regionale netværk og brancheforeninger. I gennemførelsen af disse opgaver skal Swentec føre en dialog med alle interessenter.

Swentec kommenterer selv i en rapport til regeringen i maj 2009, hvordan opgaven skal gribes an. ${ }^{234}$ Denne rapport gennemgår en række forhold ved Swentecs aktiviteter og opgavens løsning.

\section{Handlingsplan for svensk miljøteknik}

I december 2009 afleverer Swentec sit vigtigste dokument til regeringen: Handlingsplan för svensk miljöteknik. ${ }^{235}$

Der peges i handlingsplanen på 5 strategiske områder, som er helt centrale for udviklingen af svensk miljøteknik. Disse 5 strategiske områder er følgende:

- Politisk styring. Det er vigtigt, at der er et tydeligt politisk lederskab på området, ellers er det vanskeligt for et nyt område at vokse frem. Der nævnes bl.a. målformuleringer for de forskellige involverede myndigheder

- Kompetence for bæredygtig udvikling. Det er vigtigt, at man i Sverige har de rigtige kompetencer til at gennemføre den foreslåede udvikling af miljøteknik. Det er også et uddannelsespolitisk spørgsmål at fremme sådanne kompetencer hos alle involverede aktører

- Kommercialisering. Mulighederne for finansiering skal blive bedre i Sverige, ellers lykkes det ikke at fremme flere forskningsresultater til kommercielle produkter

- Erhvervsmodeller. Der skal udvikles skræddersyede erhvervsmodeller til forskellige markeder, hvilket både er hjemmemarkedet og forskellige internationale markeder. Kommunerne og det internationale udviklingsarbejde skal inddrages i denne proces

- Koordination. Det er vigtigt, at der skabes en bedre koordination mellem de mange forskellige aktører på området. Færre statslige aktører bør have flere ressourcer

I denne handlingsplan beskrives 82 aktiviteter eller anbefalinger, som skal bidrage til at fremme visionen om en stærk udvikling for miljøtekniksektoren i Sverige. Nogle af disse anbefalinger gentages her, fordi de er så vigtige i forsøget på at fremme en udvikling i Sverige af miljøtekniksektoren. Alle kan dog ikke gentages, så et centralt udvalg er valgt nedenfor:

${ }^{234}$ Swentec: Rapport till regeringen maj 2009. Vägen mot en effektiv struktur för svensk miljöteknik, maj 2009, 29 sider.

235 Swentec: Handlingsplan för svensk miljöteknik, december 2009, 82 sider. 


\section{Ad 1) Politisk styring}

- Indrette et ekspertråd, som er med til at implementere politikken over mandatperioderne

- Formulere integrerede mål for myndighederne, så der er fælles overordnede mål

- Gennemføre vurderinger af helhedsbilledet

- Formulere en partioverbyggende vision for at sikre indsatsen på lang sigt

- Sikre stabile spilleregler i reguleringen

- Gøre myndighedernes programperioder længere

- Anvende koordinerede udvælgelseskriterier for støtte til virksomheder

- Øge kompetencen hos købere og sælgere ved offentlige udbud

\section{Ad 2) Kompetence for bæredygtig udvikling}

- Styrke de forskellige uddannelser med kompetencer om bæredygtig udvikling

- Styrke kompetencen om bæredygtig udvikling hos virksomheder, myndigheder etc.

\section{Ad 3) Kommercialisering}

- Finansiere demonstrationsanlæg til at vise markedet mulighederne

- Styrke miljøkrav i udbud

- Rette støtte mod grupperinger af virksomheder frem for enkelte virksomheder

- Lave fordelagtige skatteregler for risikokapital

\section{Ad 4) Erhvervsmodeller}

- Støtte virksomhederne med at finde internationale samarbejdspartnere

- Fortsat støtte de satsninger som er igangværende

- Fremme de statslige aktørers markedsforståelse

- Fremme kommunernes rolle som hjælpere

- Prioritere teknisk samarbejde indenfor miljøtekniksektoren

\section{Ad 5) Koordinering}

- Tydeliggøre myndighedernes roller

- Skabe mere information og åbenhed om aktiviteterne

- Lave en national organisation til miljøteknikbesøg

- Stille krav om opfølgning og resultater

- Fokusere på de virksomheder som vokser

- Fremme koordinering mellem virksomheder 
Det var 25 af nogle af de vigtigste anbefalinger, som udbygges i handlingsplanen. Et lille afsnit om, hvordan en effektiv struktur for svensk miljøteknik kan se ud, afslutter handlingsplanen. Heri fremhæves igen det ret diffuse overbliksbillede af den svenske miljøtekniksektor, bl.a. de statslige myndigheders rolle. Det er bemærkelsesværdigt, at der udtrykkes så kraftig en kritik af de bestående forhold i Sverige. Dette er ikke almindeligt, heller ikke i forslag om, hvordan fremtiden skal formes, at fremføre en så skarp kritik. Swentec siger selv, at man i Swentec har startet en række aktiviteter, som trækker i den rigtige retning, men de skal følges op.

Swentec udgiver også i november 2010 en interessant rapport om Fremtidens miljøteknik, som er innovationer på områderne for IT, bio-, rum- og nanoteknik. ${ }^{236}$ Swentec vurderer, at vidensintensive fremtidsområder som IT, bio-, rum- og nanoteknik kan styrke svensk miljøteknik. De kan også være basis for store dele af fremtidens miljøteknik. Nye teknikker kan tilpasses mange forskellige sektorer og brancher. Et samlet omdrejningspunkt er, at der satses betydelige forsknings- og udviklingsmidler på disse områder, og det vil givetvis føre til særlig hurtig udvikling på disse områder. Disse teknologier vil ganske givet stå centralt i fremtidens vandrensning, vedvarende energi og forskellige former for nye systemløsninger. Rapporten kommer med en række anbefalinger på hvert område for, hvordan det kan føre til nye muligheder eller innovationer indenfor miljøteknikken. Man kan nævne grøn IT og GMO'er som udviklinger, det bliver interessante at følge.

Projektet om fremtidens miljøteknik har også udgivet en eksempelsamling, som beskriver et antal teknikker indenfor for IT, bio-, rum- og nanoteknologi, som er bemærkelsesværdige i forhold til miljøteknik. ${ }^{237}$ Det er ikke unikke teknologier som sådan, idet de ofte i andre sammenhænge beskrives under andre overskrifter, f.eks. vedvarende energi, vandrensning osv. Men det dog meget interessant at se teknologierne beskrevet i denne sammenhæng og i relation til de nye teknikområder.

\section{Swentec' arbejde med affaldsbranchen}

Som et eksempel på Swentec's arbejde med en af brancherne inden for miljøtekniksektoren kan man nævne affaldsbranchen. Her lavede Swentec allerede i marts 2008 en analyse af affaldsbranchen. ${ }^{238}$ Denne analyse skildrer affaldsområdet ved affaldshåndtering og genanvendelse på en rimelig traditionel måde. Den er ganske oplysende om forholdene

\footnotetext{
236 Swentec: Framtidens miljöteknik. Innovationer från de kund skabsintensiva spetsområderne IT, bio-, rymd och nanoteknik, november 2010, 138 sider.

237 Swentec: Exempelsamling - företag, produkter och verksamheter. Kompletterande material till Swentecs rapport „Framtidens miljöteknik“ fra november 2010, 20 sider.

238 Swentec: En kartlägning av svensk avfallshantering och återvinning - Spjutspetskompetensen, marts 2008,74 sider.
} 
for virksomhederne i Sverige. Den afsluttes med en gennemgang af 31 enkelte virksomheder indenfor affaldsbranchen.

Denne rapport om affaldsbranchen følges op af en anden rapport om, hvordan man kan få mere eksport ud af affaldsbranchen. ${ }^{239}$ I rapporten identificeres hindringer og foreslås strategier for, hvordan Sverige kan agere for at øge affaldsbranchens konkurrencekraft på eksportmarkederne. Blandt løsningsforslagene er, at man i Sverige skal skabe en national platform, der kan samle interessenterne, belyse fælles behov og skabe klarhed over relevante problemstillinger.

Med sådanne to rapporter får Swentec sat gang i drøftelserne om, hvordan man kan gøre det bedre i affaldsbranchen.

\section{Slutbetænkning fra Swentec}

I november 2010 afleverer Swentec sin slutbetænkning til regeringen. ${ }^{240}$ Der er tale om en flot slutbetænkning, som giver et udmærket overblik over Swentecs aktiviteter i årene 2008-2010.

Swentec har haft et budget på 10-12 mio. SEK hvert år og havde det senest år 7 ansatte. Et råd bestående af 8 personer var tilknyttet Swentec.

Swentec har gennemført en lang række aktiviteter, bl.a. kan nævnes:

- Gennemføre adskillige seminarer eller workshops

- Udgive 34 publikationer, heriblandt dog også mindre udgivelser

- Etablere en miljødatabase med virksomheder i Sverige

- Udgivelse af rapporter, nyhedsbreve, debatindlæg, messer, netværkstræf etc.

- Opbygge en statistik sammen med SCB

- Etablere en besøgsorganisation

- Udgive en finansieringsguide

- Udgive et katalog over eksempler på miljøteknik

I slutbetænkningen gennemgås også elementerne i handlingsplanen, som det vigtigste dokument.

Med udgangen af året 2010 lukker Swentec, og lederen af arbejdet Berit Gullbransson udtrykker, at hun mener, at det vigtigste fremover er bedre koordinering i Sverige, og at regeringen følger op på handlingsplanen. ${ }^{241}$

\footnotetext{
239 Swentec: Swedish Waste Offer, Etapp 1, december 2009, 34 sider. 


\subsection{Overblik og samlede tiltag fra regeringens side}

I forbindelse med EU-kommissionens program ETAP har Sverige ved Swentec lavet en beskrivelse af, hvad der foregår i Sverige for at fremme miljøteknik. ${ }^{242}$ Publikationen giver et overvældende overblik over, hvad der er sat i gang i Sverige, og hvem der er aktører. Der er mange informationer og ganske vanskeligt at vurdere prioriteringen i initiativerne. Det må vurderes, at rapporten er dækkende i betydeligt omfang for aktiviteter, der er gennemført til årsskiftet 2008/09. Og det må dermed vurderes, at rapporten er ret fyldestgørende for Sverige i perioden frem til dette årsskifte.

Rapporten har en række konklusioner, som skal nævnes:

- Miljøteknik gør det muligt at kombinere vækst med godt miljø

- Miljøteknik er både en sektor i sig selv, men medvirker også som drivkraft for virksomheder og organisationer til at forbedre deres miljøpræstationer

- Der er bred konsensus om, hvilke områder, som er svenske styrkepositioner, vigtigheden af samarbejde mellem industri, styrelser og universitetsverdenen, samt hvilke strategiske satsninger, der skal gøres i fremtiden

- Sverige har styrke i integrerede systemløsninger og i den generelle tilgang til gode miljøløsninger. Dette skal udvikles og styrkes

- Både udbuds- og efterspørgselssiden er vigtig, når man skal fremme miljøteknik. Fortsat fremme af miljøteknisk udvikling og udnyttelse af ny forskning er vigtig

- Efterspørgslen skal styrkes ved, at regeringen bruger styringsinstrumenter og incitamenter til at fremme markedet for miljøteknik. Dette skal ske ved standarder, miljøkrav i offentlige udbud, udvikling af udbud til teknik og innovation, aggressiv brug af offentlig finansiering til at styrke hjemmemarkedet ikke mindst ved at skabe flere demonstrationsanlæg og referencer. Staten og dens styrelser skal være gode rollemodeller på miljøområdet

- Samarbejdsmodeller og nye erhvervsmodeller skal udvikles i fremtiden

- Kommunernes kompetencer skal også bruges strategisk til at udbyde innovation og teknologi, samt ved kommercialisering

- At fremme implementeringen af udenlandsk miljøteknik i Sverige, inklusiv udenlandske investeringer i Sverige er meget vigtig

242 Swentec: Swedish strategies and initiatives for promotion of environmental technology. A National Roadmap for the implementation of ETAP, december 2008, 73 sider. 
Den svenske regering har gjort udvikling og brug af miljøteknik til et prioritetsområde i sin mandatperiode for 2007-2010. ${ }^{243}$ På klimaområdet blev der tidligere afsat 1 mia. SEK, og regeringen besluttede i september 2008 at afsætte yderligere 3 mia. SEK til klima- og energiløsninger. 1 mia. af disse midler blev afsat til udvikling af 2 . generations biobrændstof. Kommercialiseringen og spredningen af nye energiteknologier er en vigtig del af dette initiativ.

Det må nævnes, at den svenske regering har afsat 4 mia. SEK til klimabistand i sit internationale bistandsprogram. Hermed kan der ske en fremme af klimavenlige teknologier internationalt, og dette bidrager også til at fremme overførsel af klimateknologier fra Sverige.

Til forskning og innovation blev der i perioden 2009-2012 afsat 500 mio. SEK til miljø- og klimaforskning. Hovedvægten er blevet satsning på energiområdet med en budgetramme på 310 mio. SEK, mens bæredygtig udnyttelse af naturressourcer, klimamodeller og klimaeffekter på naturen er andre indsatsområder. Især må flere aktiviteter på energiområdet og udnyttelse af naturressourcer nævnes i forhold til miljøteknik. Bæredygtig udnyttelse af naturressourcer har fokuseret på „green mining“ for at fremme en mindre miljøbelastende mineindustri. Og energiområdet har fokuseret på en lang række af projekter som biomasse, bioetanol samt bølgekraft etc. ${ }^{244}$

I juni 2007 besluttede regeringen at etablere et større program for forskning og udvikling i miljøvenlig transport til 245 mio. SEK i perioden 2007-2010. Fokus er fremme af mere energieffektive transportmidler eller energieffektive motorsystemer og brugen af vedvarende brændstofkilder. Af midlerne er 125 mio. SEK afsat til et særligt samarbejde med USA om at udvikle mere effektive lastbiler og om deres brug af biobrændstoffer. Både universiteter og private virksomheder har fået del i midlerne, men det må også påpeges, at $\mathrm{AB}$ Volvo har modtaget $65 \%$ af de 245 mio. SEK. Samlet har 34 projektet modtaget støtte i programmet. Og samlet set er der brugt 890 mio. SEK, når branchens egne midler medregnes. Energimyndigheten har været ansvarlig for bevillingen frem for VINNOVA og Formas efter en vurdering fra flere myndigheder. Man må fremhæve nogle af resultaterne:

- Projektet Grøn Bil, GB3, som har nedbragt brændstofforbruget i forskellige prototyper med 5-30\%

- Både Scania og Volvo rapporterer om prototyper, som kommer på markedet om 5-10 år

- En række patenter er udtaget, bl.a. inden for drive-line

243 Denne halve side bygger på informationer oplyst på side 6-11 i rapporten nævnt i den foregående note. 244 Teknikmarknad: Notat om tilskudsmidler, november 2011, 13 sider. 
- Forskningsmidlerne har resulteret i systemer, som anvendes i et flertal af prototypemodeller

Som noget særligt er der lavet en uafhængig evaluering af indsatsen med en rapport fra Technopolis om evaluering af miljømålrettet transportforskning. ${ }^{245}$ Denne evalueringsrapport giver en ganske fremragende vurdering af indsatsen.

Initiativerne for at fremme vindenergi er blevet tilført 350 mio. SEK for perioden 2008-2012, især havvindmøller og vindmøller i bjerge har prioritet. Programmet for vindenergi bygger på vindprogrammer fra 2004. For en detaljeret beskrivelse af, hvad der sker i programmet henvises til notatet fra Teknikmarknad. ${ }^{246}$

I november 2008 besluttede regeringen at tilføre initiativerne til fremme af gårdbaseret biogas 160 mio. SEK i perioden 2009-2013. Jordbrugsverket er ansvarlig for bevillingen. Der arbejdes med 3 miljøkvalitetsmål: ${ }^{247}$

- Ingen overgødskning

- Rige naturlandskaber

- Begrænset klimapåvirkning

Programmet er en del af jordbrugsprogrammet for 2007-2013. Satsningen har været meget vellykket og antallet af producenter er blevet øget med gange 3, idet der inden programmet startede i 2009 kun var 10 gårde, som producerede. ${ }^{248}$ En evaluering er blevet påbegyndt, men ingen resultater kan præsenteres endnu.

Det daværende NUTEK og det nuværende Tillväxtverket har i perioden 2008-2010 et program til miljødrevet erhvervsudvikling, hvor der er afsat 35 mio. SEK. Programmet skal fremme kommercialiseringsfasen for nyudviklede produkter. 60 virksomheder har fået tilskud. Projektet er lige ved at gennemføre en evaluering. ${ }^{249}$ Der er blevet satset på:

- Netværk og matchmaking

- Miljødrevet erhvervsudvikling

- Udvikling af systemløsninger

- Støtte og koordinering ved udbud

\footnotetext{
245 Technopolis: Utvärdering av Miljöinriktad fordonsforskning, juni 2011, 23 sider.

246 Teknikmarknad: Notat om tilskudsmidler, november 2011, 13 sider.

247 Teknikmarknad: Notat om tilskudsmidler, november 2011, 13 sider.

248 Jordbrugsdepartementet: Jordbruksprogrammet 2007-2013, 2010, 372 sider.

${ }^{249}$ Teknikmarknad: Notat om tilskudsmidler, november 2011, 13 sider.
} 
Projektet har resulteret i udgivelse af et antal publikationer om systemløsninger, cleantech, kommuners efterspørgsel etc.

VINNOVA har i perioden 2008-2010 40 mio. SEK til at gennemføre et program for fremme af investeringer i IT og miljøteknik, inklusiv forskning i udvikling af bæredygtige byer.

Som budgetforslag for 2012-2014 vil regeringen afsætte 2,9 mia. SEK til udvikling af energiteknologi. Demonstrationsaktiviteter prioriteres sammen med fokus på langsigtet strategisk energiplanlægning. 140 mio. SEK skal bruges til rådgivning til at sprede og gennemføre tilpasning af nuværende teknologi. Forskning får tilført 210 mio. SEK., 30 mio. SEK skal bruges til smart energinet, energieffektivisering får 220 mio. SEK, biogas skal have 180 mio. SEK. Beslutningen herom forventes i december $2011 .{ }^{250}$

Dette var nogle af vigtigste initiativer, der er afsluttet for nylig, er i gang eller skal komme i Sverige.

\section{Bæredygtige/Hållbare byer}

I september 2008 blev der etableret en delegation for at fremme bæredygtige/hållbare byer. Denne delegation virker i perioden 2008-2012 og skal være det nationale samlingspunkt for arbejdet med bæredygtige byer. Delegationen skal også formidle og styre de midler, som er til rådighed til at fremme bæredygtige byer. Klimaprofilen skal være rimelig tydelig i bevillingen af midlerne. Delegationen består af en bestyrelse på 15 bestyrelsesmedlemmer og et sekretariat, som hidtil har haft 5 ansatte pr. år i gennemsnit. Af de tilgængelige midler har der hvert år været 10 mio. SEK til administrationen af delegationen mv. Delegation er tilknyttet Miljöverndepartementet. Delegationen har sin egen hjemmeside www.hallbarastader.gov.se

Bæredygtige byer er en ny helhedstilgang til byudvikling, som omfatter mange forskellige temaer:

Effektive affaldssystemer, efterbehandling af forurenede områder, en motor for vækst, energieffektivisering, vedvarende energi, natur i og nær byer, planlægning af miljøvenlige transporter, smarte bygninger og byggemetoder, byen som attraktiv livsmiljø, vand og afløb i kredsløb etc.

Den totale finansiering fra delegationen og dets sekretariat er følgende:

2009140 mio. SEK

2010200 mio. SEK

201130 mio. SEK

201230 mio. SEK

I alt 400 mio. SEK

250 Proposition 2011, 12:1. 
Delegationen har afrapporteret de første 2 år til regeringen med en SOU af den 22. december $2010,{ }^{251}$ dvs. forbruget af de 340 mio. SEK. I denne rapport gennemgås en lang række af forhold ved delegationens arbejde med bæredygtige byer. Det er en ganske omfattende rapport med mange detaljer. Som eksempel på hvad der er givet tilskud til, kan det fortælles, at delegationen i 2009 gav støtte til 3 investeringsprojekter og 14 planlægningsprojekter.

Arbejdet med bæredygtige byer følges af Riksdagen, som har lavet en egen vurdering. ${ }^{252}$ Denne vurderings sammenfatning har følgende konklusioner:

- Bæredygtig byudvikling er ikke tilstrækkelig godt defineret, hvilket har medvirket til at indretningen af statens satsning er blevet utydelig

- Mange myndigheder arbejder med bæredygtig byudvikling, hvorfor det er vigtigt med en tydelig ansvarsfordeling mellem myndighederne. Der er både fordele og ulemper ved, at arbejdet er organiseret som en delegation

- Arbejdet bør præges af langsigtethed og kontinuitet, og det bør målrettes både små og store byer i hele landet

- Bidraget har medvirket til at sætte gang i byudviklingsaktiviteter, men det er for tidligt at bedømme bidragets faktiske effekt

- Der er begrænset nytænkning i de projekter, som har søgt om midler og få tydelige eksempler på muligheder for øget miljøeksport. Ansøgningsprocessen har været relativ enkel

- Grønområdernes vigtighed er blevet ønsket vægtet i satsningen på bæredygtig byudvikling. Dette er sket, og det er fortsat vigtigt at følge dette

- Det er vigtigt, at satsningen følges op og vurderes, samt at resultaterne spredes. Regeringen bør også årligt informere om og bedømme resultaterne af de indsatser, som bliver gjort på området

Skønt Riksdagens vurdering ikke er en traditionel uafhængig ekstern vurdering, giver den dog en række informationer til at sætte indsatsen i et bredere perspektiv. Det er noget nemmere at forstå denne tilgang end den traditionelle beskrivelse, som ikke er synderlig kritisk.

I februar 2011 udgav VINNOVA, Sveriges innovationsstyrelse en publikation med titlen: Framtid med växtvärk om bæredygtige byer, og hvilket markedspotentiale der er i byerne for miljøteknik. ${ }^{253}$

\footnotetext{
251 SOU: Delegationen för Hållbare städer, Miljövårdsberedningen jo 1968:a, 115 sider.

252 Rapport fra Riksdagen: Uppfölgning av statens satsning på hållbare städer, Stockholm 2010, 295 sider.

253 VINNOVA: Framtid med växtvärk. Kan hållbare städer möta klimatutmaningarna?, 2011, 80 sider.
} 


\section{Rapportens hovedkonklusioner er:}

- Bæredygtige byer handler ikke kun om miljø, men også om økonomi og social bæredygtighed

- Udviklingen af byerne er snarere en proces end en tilstand. Sverige betragtes internationalt som langt fremme inden for mange af de temaer, som berøres

- Der findes en række delmarkeder i forbindelse med udviklingen af bæredygtige byer, ikke kun et marked. Dette betyder, at markedsforudsætninger, behov og løsninger er forskellige

- Erhvervsforudsætninger og -modeller viser forskellige karakteristika afhængig af de involverede aktører. Man kan nævne forskellen mellem private og offentlige aktører

- Bæredygtige byer indebærer et nyt og vanskeligere niveau af integration og systemtænkning

I vurderingen af byers udvikling identificeres to stærke tendenser: 1) en strukturel transformering mod en meget større andel af befolkningen bosiddende i byer, og 2) de lokale og globale miljø- og klimaudfordringer. Ikke mindst for det globale klima har det betydning, hvad der sker i byerne, idet man bruger $75 \%$ af energi i byerne, selv om det kun er halvdelen af befolkningen, der bor i byerne.

En række virksomhedsområder nævnes i forbindelse med udfordringen at udvikle bæredygtige byer:

- Byplanlægning, som får et langt større ambitionsniveau end den hidtidige mere fragmenterede byplanlægning

- Byggesektoren, som ligeledes får langt flere udfordringer og skal realisere flere ambitioner

- Den grundlæggende infrastruktur med energisystemer, vandsystemer og affaldshåndtering

- Kommunikation og transport

- Informations- og kommunikationsteknologi (IKT)

- Tjenester for indbyggere og virksomheder

På samtlige disse virksomhedsområder handler løsningerne ikke bare om teknik og innovation. Der skal ofte skabes helt nye og mere komplekse løsninger.

I et byudviklingsperspektiv ser publikationen på 3 situationer for udvikling af byer:

- Nybygninger af bydele eller hele byer. I dette marked er der stor frihed til at planlægge og gennemføre nye løsninger

- Ombygning eller renovering handler om at erstatte eller forbedre den bestående infrastruktur. Dette marked er det største på kort sigt 
- Slumforbedringer indebærer en social problemstilling, i og med at det typisk er områder, hvor der bor mange fattige

Publikationen foretager også en vurdering af mulighederne for svensk erhvervsliv. Hjemmemarkedet i Sverige betragtes som utroligt vigtigt, i og med at Sverige vurderes som et foregangsland. En række virksomheder nævnes inden for de respektive virksomhedsområder.

Og endelig nævnes en række eksempler på bæredygtige byer i Sverige. Mest kendt er vel Hammerby Sjöstad i Stockholm, men Norra Djurgårdsstaden nævnes også som den næste større satsning i Stockholm. Malmø nævnes med området i forbindelse med messen Bo01 2001. Andre bydele nævnes.

Rapportens styrke er, at den beskriver et forholdsvist nyt område, bæredygtige byer, samlet med mange forskellige aspekter, miljømæssige og ikke mindst erhvervsmæssige, og den skitserer hvilke muligheder dette giver for svenske virksomheder. Hvis man ikke kender ret meget til begrebet bæredygtige byer, og hvordan mulighederne udvikler sig her, er det et udmærket sted at starte og skabe sig et overblik.

Rapportens svaghed er omvendt, at den ikke kommer tilstrækkeligt dybt ned i temaet, sikkert fordi temaet består af mange forskellige temaer, som ses i sammenhæng. Det gør den vanskelig for virksomheder at bruge, som mere detaljeret inspirationskilde.

\subsection{Den svenske regerings strategi for miljøteknik i 2011}

Den svenske regering præsenterede den 1 . september 2011 en ny strategi for udvikling og øget eksport. ${ }^{254}$ Sammenlagt skal der med strategien bruges 400 mio. SEK ekstra, fordelt med 100 mio. SEK pr. år i årene 2011-2014. Grundlaget for strategien er et omfattende arbejde, som er gået forud for selve strategien helt fra 2008. Især Swentec' arbejde har været anvendt, i og med at Swentec præsenterede sin slutrapport for regeringen i november 2010, jf. ovenfor.

Regeringens miljøteknikstrategi har 3 hovedformål:

- At tilvejebringe gode forudsætninger for vækst og udvikling af miljøteknikvirksomheder i Sverige

- At fremme eksport af svensk miljøteknik og dermed bidrage til holdbar økonomisk vækst i Sverige og globalt 
- At fremme forskning og innovation indenfor miljøteknik og hjælpe innovationer med at blive kommercialiseret

Regeringens strategi gennemgår det internationale marked for miljøteknik generelt og mere specifikt. Især Kina, Indien, Brasilien og Rusland, dvs. BRIK-landene, skønnes at være interessante.

Handlingsplanen omfatter især det internationale område og eksporten. Målgruppen er et par hundrede svenske virksomheder, som ønsker at eksportere mere og til flere lande. Det fremhæves, som supplement hertil, at der arbejdes på en national innovationsstrategi, som forventes færdig til efteråret 2012. Heri skal man gennemgå skridt for skridt, hvordan man kan forbedre innovationsklimaet i Sverige og skabe job og vækst på området miljøteknik. I denne nationale innovationsstrategi vil regeringen også tydeliggøre opgaver, ansvar og fokus for statslige myndigheder og aktører, som svar på den kritik der har været af, at det var uklart, hvem der havde, hvilke opgaver og ansvar.

Der lægges i regeringens strategi vægt på, at arbejdet fremover er styret af efterspørgslen, f.eks. i dialog på forskellige møder eller rundbordssamtaler, hvoraf den første er afholdt i marts 2011.

De fremtidige indsatser i perioden 2011-2014 kan opremses som følger:

- Udvikling af ressourcebasen:

a) Satsning på forskning og vidensudvikling på miljøteknikområdet og indenfor bæredygtig byudvikling (Verket for innovationssystem)

b) Videreudvikling af kortet over demonstrationsanlæg, som Swentec har udviklet (Tillväxtverket)

c) Udvikle incubatorordning med målretning på miljøteknikområdet (Innovationsbron AB)

d) Fremme mødeplads for entreprenører, aktører og investorer for at fremme kapital i den tidligere kommercielle fase (Statens energimyndighed)

- Indsats for at hjælpe behov:

a) Særlig satsning på fremme af eksport fra små miljøteknikvirksomheder, som f.eks. videreudvikling af konceptet SymbioCity (Exportrådet)

b) Særlig satsning på at fremme eksport til USA med kobling til Swedish American Green Alliance (SAGA-samarbejdet) med fokus på bæredygtigt byggeri, infrastruktur og transport (Exportrådet)

c) Det særlige svensk-kinesiske samarbejde skal udvides til også at omfatte Indien og Rusland (Regeringskansliets internationella miljötekniksamordning)

d) Særlig satsning på eksporten til Brasilien med fokus på bæredygtigt byggeri og bioenergi mm. (Exportrådet)

- Organisation og koordinering: 
a) For at øge den samlede effekt af indsatserne skal der laves en gennemgang af de forskellige aktørers opgaver for at tilvejebringe en mere tydelig og klar arbejdsdeling, især for at undgå dobbeltarbejde (Regeringskansliet)

b) Fortløbende analyse af den svenske miljøtekniksektor samt udvikling af statistik på området. Fremtidige udviklingsområder skal udvikles (Myndigheten för tillväxtpolitiska studier)

c) Udvikling af en koordineringsfunktion for national besøgshåndtering på området miljøteknik (Exportrådet)

d) Kontinuerlige dialogmøder med forskellige aktører om temaer med betydning for miljøtekniksektorens udvikling (statssekreterarne for Närings-, Miljö-, og Utriksdepartementen)

Udøver disse opgaver vil der komme flere opgaver til i perioden frem mod 2014. Sådanne opgaver kan initieres af forskellige analyser og behov.

Som en del af opfølgningen skal Myndigheten for tillväxtpolitiska studier følge og vurdere de resultater, som bliver gjort som led i strategien. Der vil blive gennemført analyser i efteråret 2012 og foråret 2014.

Det vil være nærliggende at sige, at den svenske regerings nye strategi for miljøteknik fra 2011 repræsenterer en ny generation af strategier. Den er ganske kort og meget direkte i, hvilke opgaver der skal udføres, og hvordan disse opgaver skal udføres. Den forbigår mange drøftelser om emnet og rykker direkte til det konkrete: hvad der skal ske. Tilmed er der sat myndighedsaktør på opgaverne. Et område, som ikke løses, men hvor der nævnes en køreplan, er den uklarhed eller overlap af aktiviteter, som bl.a. Swentec tidligere har påpeget eksisterer hos de statslige aktører eller myndigheder. Her pålægger regeringen sig selv at lave et udredningsarbejde for at tilvejebringe en mere tydelig og klar arbejdsdeling.

\subsection{Svenske eksempler med international succes}

I Sverige har Naturvårdsverket længe arbejdet med eksemplets magt eller der gode eksempel som instrument til at forbedre miljøpolitikken. I december 2002 udgav man en publikation med titlen: Exemplets makt, en vurdering af hvordan arbejdet med det gode eksempel fungerer i miljøarbejdet. ${ }^{255}$ Rapporten består af en undersøgelse om, hvordan gode eksempler fungerer bedst som information til at påvirke eller sprede resultater. Mange forskellige slags gode eksempler beskrives og gode eksempler på miljøteknik er naturligvis også en del af denne tilgang. Det er meget sjældent, at man finder en så interessant og velfunderet rap-

255 Naturvårdsverket: Exemplets makt. Utvärdering av hur arbetet med goda eksempel fungerar i miljöarbetet. Rapport 5259, december 2002, 74 sider. 
port om et så vigtigt tema. Normalt forudsættes blot, at gode eksempler er værdifulde i sig selv, uden refleksioner over, hvordan formidlingen og synspunkter fra afsender og modtager opfattes. Så denne publikation er yderst hjælpsom som et instrument i miljøpolitikken og også i politikken om miljøteknik.

3 anbefalinger er fremhævet som vigtige:

- Skabe bedre overblik blandt gode eksempelsamlinger via lette koblinger på nettet

- Lave en enkel vejledning eller checkliste til dem, der udvælger, dokumenterer og spreder gode eksempler

- Øge tilgangen af vurderinger af gode eksempler som er vurderet specielt ved miljøeffekt, økonomi og brugeraspekter

I rapporten foreslås, at man fortsætter arbejdet med gode eksempler, og Naturvårdsverket har selv lavet en hjemmeside, hvor man fremhæver mange gode miljøeksempler. Man beskriver en række gode miljøeksempler fra investeringsprogrammerne. De statslige investeringsprogrammer LIP, lokale investeringsprogrammer og Klimp, klimainvesteringsprogrammer er en af Sverige største miljøsatsninger og fungerer som hovedkilde til materialet om de gode eksempler. Naturvårdsverket har bevilget bidrag til totalt ca. 1.800 projekter i LIP og 913 projekter i Klimp (juni 2011). Eksemplerne er opdelt i flere områder: affald, biogas, energieffektivisering, energiomstilling, bæredygtige byer, industriel økologi, naturbeskyttelse, sanering af forurenede områder, trafik, vand og afløb, og øvrige klimatiltag. Under områder finder man så på hjemmesiden en række konkrete eksempler på gode resultater fra investeringsprogrammerne, som alle kan findes på Naturvårdsverkets hjemmeside.

Naturvårdsverket har evalueret, hvordan resultaterne fra investeringsprogrammet er blevet spredt. ${ }^{256}$

VINNOVA, Sveriges innovationsstyrelse, har lavet et projektkatalog om miljøinnovationer, som beskriver 41 eksempler på projekter, som har fået støtte fra VINNOVA. ${ }^{257}$ Projekterne præsenteres på 1 side med en række informationer om projektets indhold, formål og resultater, deltagere og finansiering.

Swentec har lavet en eksempelsamling på 143 projekter med interessante miljøteknikker. ${ }^{258}$ Det er Swentec' mandat om at lave en besøgsorganisation i Sverige, som har givet anledning til, at denne eksempelsamling over besøgssteder etableres. Der er almindelige informationer om projekternes indhold, resultater, økonomi og ikke mindst geografisk

\footnotetext{
${ }^{256}$ Naturvårdsverket: Lokala miljöinvesteringer ger globala avtryck, februar 2008, Rapport 5806

257 VINNOVA: Miljöinnovationer - projektkatalog, januar 2011, 54 sider.

258 Se Swentecs hjemmeside, som er stadig tilgængelig.
} 
beliggenhed i Sverige. Denne database administreres nu af myndigheden Tillväktverket.

Svenska Instituttet (SI) har lavet en liste med de 20 mest spændende innovationer i Sverige. ${ }^{259}$ Her er nævnt 5 eksempler på interessante innovationer indenfor miljøteknik, repræsenteret ved deres firmanavn: I-Tech, MyFC, OrganoClick, Solvatten og Xylophane. I listen er der henvisninger til firmaernes hjemmesider.

Man kan også nævne, at „Global Cleantech 100“ i 2011 har 2 svenske firmaer på listen over de mest interessante nystartede cleantech firmaer. Disse to firmaer er Chemrec, som skaber biobrændstof fra biomasse, og Climatewell, som arbejder med soldrevet aircondition. ${ }^{260}$

I en beskrivelse af svensk miljøteknik med international profil må man nødvendigvis have et eksempel fra hållbara städer/bæredygtige byer, som et ret stort satsningsområde i Sverige. Og samtidig en satsning, som ingen af de andre nordiske lande har foretaget, i hvert fald ikke under den samme overskrift. Som det vel nok kendteste eksempel må man nævne Hammerby Sjöstad, der er beliggende langs Stockholms havnefront og har strenge krav til alle bygninger, infrastrukturelle løsninger og miljø-trafik. Her har man integreret en økocyclus tilgang i byplanlægning for en hel bydel. Løsningen kaldes meget sigende for Hammerby modellen. Ideen var at reducere energiforbruget og affaldsdannelsen samtidig med, at der blev satset på ressourcebesparelser og genanvendelse af materialer.

I forbindelse med hållbara städer bør man også nævne SymbioCity, som blev etableret i 2008, og omfatter 200 virksomheder, der er interesserede i at eksportere især produkter relateret til bæredygtige byer. SymbioCity varetages af det svenske handelsråd og markedsfører miljøteknik i forbindelse med hållbare städer internationalt.

Et andet eksempel, som bør nævnes, er anvendelse af spildevandsslam som en ressource til at generere ren transport. Man har i udkanten af Stockholm udviklet 2 biogasanlæg til at bruge slam til at producere varme og gas til brændstof i bustraffikken i Stockholm.

Hvis man tager eksporttallene er Sverige stærkest på affaldshåndtering og genanvendelse, fulgt af bæredygtigt byggeri og energieffektivisering. Herefter kommer sol, vind og vandkraft og endelig bioenergi til sidst i opgørelsen over eksporten. Det er altså ganske interessant at affaldshåndtering og genanvendelse står så stærkt i Sverige, når man måler på eksporttallene.

259 Svenska Instituttet: Hela listan med Sveriges 20 hetaste innovationer, 2 sider. 260 Cleanindex hjemmeside. 
For nylig har man i Sverige udgivet en publikation med 13 svenske eksempler. ${ }^{261}$ Denne nye publikation giver et overblik over gode eksempler i Sverige.

\subsection{Arbejdet med efterspørgselssiden i Sverige}

Sveriges arbejde med miljømål er vel verdenskendt, som det bedste arbejde for at fremme konkrete miljømål og miljøkvalitetsmål forbundet hermed. Man fastlægger en række miljømål og/eller miljøkvalitetsmål, f.eks. frisk luft, begrænset klimapåvirkning, giftfrit miljø etc. og fastlægger, hvordan man over en længere årrække vil nå målet. Dette er vel nok det mest optimale instrument til at fortælle virksomhederne om fremtidig regulering og forme efterspørgsel og marked. Regeringens forslag om at revidere Svenske miljømål - for et mere effektivt miljøarbejde kan nævnes som eksempel på det omfattende arbejde, som arbejdet med miljømål og miljøkvalitetsmål har fået i Sverige. ${ }^{262}$

Ellers må man nævne miljøreguleringen generelt, også f.eks. princippet om BAT (Best Available Technology). Og man må nævne miljø-, energi- og ressourceskatterne som generelle drivkræfterne på efterspørgsel efter god miljøteknik. Selv frivillige systemer som miljøledelsessystemer, miljømærkning og miljøcertificering fører til efterspørgsel efter miljøteknik.

Som noget særlig kan man nævne, at den offentlige efterspørgsel efter tjenester og varer i Sverige i stadig stigende grad bliver indrettet mod grønne udbud. Naturvårdsverket har dog vurderet, at der stadig skal gøres meget for man kan konkludere, at der er sket et endeligt gennembrud med grønne offentlige udbud. Man kan også nævne rapporten fra Swentec om offentlig upphandling som et strategisk værktøj, som en rapport der viser vejen frem. ${ }^{263}$

I forbindelse med grønne udbud skal man også nævne andre former for udbud som udbud af teknologi og udbud af innovation. Dette er styringsinstrumenter, som udnytter udbudssituationen til at få gode resultater. Det kan nævnes, at Energimyndigheden i Sverige har identificeret 56 forskellige teknologiudbud siden 1990 på energiområdet. Udbud af innovationsprojekter er også i stadig stigende grad interessante. ${ }^{264}$

Derudover er der ikke så meget i det svenske materiale, der viser overvejelser om ekstra eller detaljeret styrkelse af efterspørgselssiden.

\footnotetext{
261 Regeringskansliet: Miljötekniklösninger - 13 svenska eksempel, september 2011, 32 sider.

262 Regeringens Proposition 2009/10:155: Svenska miljömål - för et effektivare miljöarbete, 248 sider.

263 Swentec: Offentlig upphandling som ett strategiskt verktyg, Miljöteknikföretagens konkurrenskraft, december 2009, 17 sider.

${ }^{264}$ Swedish strategies and initiatives for promotion of environmental technology, omtalt i tidligere note, side 47.
} 


\subsection{Konklusion på Sverige aktiviteter}

Der har i Sverige været en ganske systematisk fokus på sektoren for miljøteknik. Swentec og SCB, Statistiska centralbyråen, har frembragt statistik om sektoren. Det samlede antal virksomheder opgøres til 6.500 virksomheder med en omsætning på 119 mia. SEK i 2009. Uheldigvis er der mange enmandsvirksomheder, som er medtaget i denne opgørelse. Den nye svenske strategi for miljøteknik omtaler da også, at målgruppen for fremtidens arbejde er nogle hundrede virksomheder, som ønsker at øge eksporten. Sektoren vurderes til at have omkring 40.000 ansatte. Med den nye strategi har Myndigheden for tillväxtpolitiska studier fået til opgave at føre dette statistiske område videre fra Swentec. Man må gå ud fra, at SCB også fortsætter som aktør i denne statiske opgørelses udvikling. Det ville være meget interessant, såfremt man fremover ville opgøre sektoren noget mere specifikt, både samlet set og fordelt på enkelte områder. Man har allerede været meget tæt på, så der mangler givetvis kun ganske lidt for, at det kan blive langt mere optimalt og dermed fremadskuende.

Hvad angår eksporten er den vurderet til at være ca. 40 mia. SEK i 2009. Det virker som om man har et godt grundlag for at følge op på denne statistisk. Man må også gå ud fra, at det er Myndigheden for tillväxtpolitiska studier, som skal foretage denne opgørelse. Også her vil det naturligvis være interessant med en differentiering af det billede, som allerede er til stede med affaldshåndtering og genanvendelse, som det største område. Og det vil være interessant, hvis man får en årlig opgørelse.

Helt centralt i den svenske indsats for miljøteknik står Sveriges miljøteknikråd, Swentec. Swentec har lavet rigtig mange og gode rapporter og har gjort utrolig meget for området. Dette er gjort for et budget på 10-12 mio. SEK pr. år og en stab på ca. 7 ansatte, så det må siges at være omkostningseffektivt gjort. Man har tilmed lavet et forslag til fremtidig handlingsplan for miljøteknik i Sverige og afsluttet sit arbejde på en konstruktiv måde med en slutbetænkning til regeringen. Naturligvis har Swentec kunnet trække på en række vidende folk og institutioner i Sverige, som allerede har været inde i vigtige temaer for sektoren om miljøteknik. Der synes ikke at være en lignende koncentreret kraft til at fremme området i den nye strategi for miljøteknik. Derfor er det egentlig med beklagelse at man må konstatere, at Swentec er blevet nedlagt. Der var aldrig tvivl om opgavens karakter, og hvem der var ansvarlig. Swentec havde et ret klart mandat og en opgave at udføre.

Swentec har i en række rapporter beskrevet sektoren og bl.a. også lavet det store oversigtsværk over aktiviteter i Sverige, som har været koblet til EU-kommissionens ETAP-program. Swentec har lavet en finansieringsguide og en besøgsorganisation med en hjemmeside med lokaliteter. Man har afholdt seminarer, drøftet politik og sat opgaver i gang i betydeligt omfang. På trods af dette må man også sige, at der mangler en række dybdeborende analyser af de enkelte dele af sektoren i Sverige. Tager man 
Swentec's eksempel fra affaldsbranchen, bør der være en ny gennemgribende analyse, naturligvis byggende på det allerede foretagne arbejde.

Et svensk indsatsområde, som er værd at fremhæve, er arbejdet med hållbare städer/bæredygtige byer. Her har Sverige en unik position blandt de nordiske lande, fordi ingen andre lande har foretaget en sådan satsning. Der har været afrapportering fra delegationen, en vurdering fra Riksdagen, samt en rapport fra VINNOVA om perspektiverne ved satsningen på bæredygtige byer. Samlet set er der rigelig materiale til, at Sverige kunne producere en rapport/beskrivelse, som kan forklare fordele og ulemper ved at satse på bæredygtige byer. Det er en meget lovende satsning, men den er også langsigtet, fordi at planlægge og bygge nye byområder eller renovere gamle byområder på bæredygtig vis tager lang tid. Der vil derfor gå en række år, før vi får den fulde effekt at se. Ikke desto mindre vil andre nordiske lande kunne have god gavn af en sådan beskrivelse.

Swentec afleverer sin handlingsplan for svensk miljøteknik i december 2009 og lukkes med udgangen af 2010. Den nye svenske strategi bliver først offentliggjort primo september, dvs. 11/2 år efter forslaget til handlingsplan. Det må siges at være for længe, hvis man skal have rigtig gang $i$ et område.

Som en særlig svensk ekspertise må man nævne offentlige grønne indkøb eller udbud. Her er Sverige ledende blandt de nordiske lande, og det vil være meget hjælpsomt, om Sverige ville samle hele sin erfaring i en enkelt publikation, de kan anvendes af andre.

Den nye svenske strategi må siges at være prisværdig kort og meget målrettet på en række centrale områder. Man har lært af tidligere for store arbejder, hvor det er vanskeligt at følge op på alle anbefalingerne. Strategien skal dog udfyldes og gennemføres. Der synes at mangle et klart centrum for ansvaret for strategien. Det er dog relevant at slå fast, at man med strategien får en rimelig klar statslig strategi med fordeling af en række opgaver. Et problem, som skal løses, er dog en mere klar arbejdsdeling mellem statslige aktører. 



\section{Litteraturliste}

Der er lavet en litteraturliste over hvert enkelt afsnit, idet det gør det lettere at finde litteraturen.

\section{Sammenfatning}

Brøndum \& Fliess: Cleantech - i vækstens tegn. Guldægget i dansk økonomi 2010, oktober 2010, 69 sider.

KONE: Planlægning frem til 2050. KONE Eco-efficient-løsninger, 2 sider.

\section{Indledning}

Commission of the European Communities: Report from the Commission: Environmental technology for sustainable development, Brussels, 13.03.2002, 23 sider.

Commission of the European Communities: Communication from the Commission to the Council and the European Parliament: Stimulating Technologies for Sustainable Development: An Environmental Technologies Action Plan for the European Union, Brussels, 28 January 2004, 40 sider.

CEC: Report on the implementation of ETAP in 2004, January 2005, 6 sider.

CEC: Report on the ETAP (2005-06), May 2007, 13 sider.

Daniel C. Esty and Andrew S. Wilson: Green to Gold, How smart Companies use environmental strategy to innovate, create value, and build competitive advantage, New haven and London 2006, 366 sider.

Europa-Kommissionen: Europa 2020, En strategi for intelligent, bæredygtigt og inklusiv vækst, marts 2010.

Europa Kommissionen: Meddelse fra Kommissionen til Europa-Parlamentet, Rådet, det europæiske økonomiske og sociale udvalg og Regionsudvalget: Køreplan til et ressourceeffektivt Europa, 20. september 2011, 25 sider.

European Commission: Communication from the Commission to the European Parliament, The Council, The European economic and social committee of the regions: Innovation for a sustainable Future - the Eco-innovation Action Plan (Eco-AP), udkast fra December 2011, 20 sider.

Eco-Innovation Observatory: The Eco-innovation Challenge, Pathways to a resourceeffective Europe, Annual Report 2010, May 2011, 110 sider.

Eco-Innovation: EIO country brief 2010: Denmark, Finland, Sweden, ca. 17 sider hver.

Eco-Innovation Observatory: methodological Report, Autumn 2010, 104 sider.

Institut for Miljøvurdering: Green Roads to Growth, Procedings of Expert and Policy Makers Forum, held in Copenhagen 1-2 March 2006, 500 sider.

Norden: Nordic Environmental Technology, TemaNord 2006:701, 20 sider.

Norden: Innovation Systems and Environmental Technologies, TemaNord 2008:565, 80 sider.

Norden: Environmental Technology and Innovation - Drivers and Policy measures, Summary notes from the NMRIPP Conference, Copenhagen, 2-3 september 2008, januar 2009, 44 sider.

Norden: Green Public Procurement makes a difference! Prime examples from the Nordic countries, 2009, 24 sider.

Norden: innovative Green Public Procurement of Construction, IT and Transport Services in Nordic countries, udarbejdet af Planmiljø, December 2009, TemaNord:529, 103 sider. 
Norden: Benefits of Green Public Procurement, udført af Bjørn Bauer etc. 67 sider. Norden: The Clean TechMarket Survey, TemaNord 2010:591, 39 sider.

Norden: Kundskab för grön tillväxt. Huvudrapport om arbetet för grön tillväxt ur et utbildnings-, forsknings- og innovationsperspektiv,december 2011, TemaNord 2011:552, udført af Sweco Eurofutures, 92 sider, samt Delrapport 2 om aktiviteter vid de nordiska tekniska högskoler och universitet, udført af Nordtek, 51 sider.

Nordic Innovation Center: nettverksamarbeid i Norden for eksport av miljøteknologi (Forprosjekt), maj 2006, 32 sider.

Nordic Innovation Center: Nordic Environmental Solutions (NETS) - Commercialization of key business sectors, November 2008, 37 sider.

Nordisk Ministerråd: Greening the Economy: Nordic experiences and challenges, „Synthesis report“, udført af Vista analyse, den 31. January 2011, 121 sider.

Nordisk Ministerråd: Miljösektorns workshop om grön ekonomi, 10. juni 2011, workshopmateriale og overheads etc.

OECD and Eurostat: The environmental goods and services industry - manual for data collection and analysis, 1999.

OECD Report: Assessment of the ETAP roadmaps with regard to their eco-innovation potential, 2010 (December 2009), 176 sider.

OECD: Declaration on Green growth, juni 2009.

OECD: Interim report on the Green Growth Strategy. Implementing our commitment for a sustainable future, May 2020.

OECD: Towards Green Growth, maj 2011, 144 sider, samt Summary for policy makers, og Tools for delivering on Green Growth, 25 sider.

Ron Pernick and Clint Wilder: The Clean Tech Revolution, The next big growth and investment opportunity, New York 2007, 308 sider.

UNEP: Towards a Green Economy: Pathways to sustainable development and poverty eradication, februar 2011, 626 sider, samt Summary of conclusions and Synthesis for policy makers.

\section{Danmark}

Aftale mellem regeringen og Dansk Folkeparti om fremme af miljøeffektiv teknologi 2007-09 (4. november 2006).

Aftale mellem regeringen (Venstre og Det Konservative Folkeparti), Socialdemokraterne, Dansk Folkeparti, Socialistisk Folkeparti, Det Radikale Venstre og Ny Alliance om den danske energipolitik i årene 2008-2011, 21. februar 2008, 4 sider.

Aftale om en ny handlingsplan til fremme af miljøteknologi, den 29. februar 2009.

Aftale om Grøn vækst, 16. juni 2009, 18 sider.

Aftale mellem regeringen (Venstre og Det Konservative Folkeparti), Socialdemokratiet, Dansk Folkeparti og Det Radikale Venstre om: Fordelingen af globaliseringsreserven til innovation og iværksætteri mv. 2010-2012, 5. november 2009, 6 sider.

Aftale om Danmark som vækstnation, 27. maj 2011, 15 sider.

Bekendtgørelse nr. 864 af 30. juni 2010 om tilskud til miljøeffektiv teknologi.

Berlingske Tidende den 17. juni: DI: Regeringen svigter dansk miljøteknologi.

Brøndum \& Fliess: Cleantech - I vækstens tegn. Guldægget i dansk økonomi 2010, oktober 2010, 69 sider.

Brøndum \& Fliess: Cleantech - with the customer in focus - The Golden Egg of Danish Economy 2011 - with inspiration from seven cases, juni 2011, 57 sider.

By- og Landskabsstyrelsen: Handlingsplan for hospitalsspildevand, maj 2009, 5 sider.

Center for Grøn Transport, Trafikstyrelsen: Redegørelse om elbiler og plug-in hybridbiler, april 2010, 65 sider.

Concito (tænketank): The Annual Climate Outlook of Denmark (ACO), maj 2010, (som dog på trods af titlen er på dansk), 178 sider.

Danmarks nationale Allokeringsplan 2008-2012, 6.marts 2007, 88 sider. 
Dræbye: grundlaget for statistik for energierhvervene, april 2010.

Erhvervs- og Boligstyrelsen: Kompetenceklyngen Vand - en analyse af virksomheder og deres rammebetingelser, oktober 2002, 30 sider.

Erhvervsklimapanelet: Baggrundsrapport om de danske styrkepositioner på klimaområdet, august 2008, 97 sider.

Energi 2011, forskning, udvikling og demonstration, maj 2011, 160 sider, samt Energi 2008, Energi 2009, Energi 2010.

Energistyrelsen: Basisfremskrivning for Danmarks fremtidige energiforbrug og udledning af drivhusgasser, 18. april 2011.

Energistyrelsen: DI Energibranchen og Erhvervs- og Byggestyrelsen, Energierhvervsanalyse 2010, maj 2011, 16 sider.

Energiteknologisk Udviklings- og Demonstrationsprogram, forslag til lov og lov om programmet.

EUDP-loven, Revision af loven (Green Labs DK-programmet), oktober 2010.

EU-kommissionen: Fællesskabets rammebestemmelse for statsstøtte til forskning og udvikling og innovation af den 30. december 2006, C 323/01.

EU-kommissionens forordning nr. 1320/2006, 10 sider.

EU-kommissionens godkendelse af EUDP den 12. december 2007.

Frans Clemmensen, cheføkonom, Dansk Energi, indlæg i Politiken den 6. april 2011.

FORA: Miljøteknologiske styrkepositioner - en erhvervsanalyse af klyngedannelse, udarbejdet for Miljøstyrelsen, juni 2006.

FORA: Kortlægning af Miljøteknologiske virksomheder i Danmark, udarbejdet for Miljøstyrelsen, marts 2009, 65 sider.

Fornyelsesfonden: Handlingsplan 2011, 12 sider.

Forsknings- og udviklingsstrategi for biogas, august 2009, 19 sider.

Fødevareministeriets hjemmeside: to summariske lister over projekter.

Fødevareministeriet: GUDP, strategi 2011-2013 og handlingsplan 2011, 27 sider, som overheads, samt bilag til handlingsplan 2011: Faglig inspiration til ansøgere, 10 sider.

Fødevareministeriet: Miljøteknologi 2011, Vejledning, 21 sider.

Karsten Skov: Visioner for vandteknologi, december 2009, 6 sider.

Klimakommissionen: Grøn energi - vejen mod et dansk energisystem uden fossile brændsler, september 2010, 98 sider, samt baggrundsrapport og bilagsrapporter

Lov nr. 1572 af den 20. december 2006 om miljøgodkendelse m.v. af husdyrbrug.

Lov om Grønt Udviklings- og Demonstrations nr. 1502 af den 27. december 2009.

Lovforslag L 92 om Lov om fond til grøn omstilling og erhvervsmæssig fornyelse, 16. december 2009.

Lov nr. 113 af den 1. februar 2010 om Lov om fond til grøn omstilling og erhvervsmæssig fornyelse (Fornyelsesfonden).

Miljøministeriet og Fødevareministeriet: Implementering af vandrammedirektivet og nitratdirektivet i Nederlandene, Slesvig-Holsten og Danmark, den 7. februar 2011, 6 sider.

Miljøstyrelsens internetside ecoinnovation.dk

Miljøstyrelsens hjemmeside om VERA.

Miljøstyrelsen: Vera - Verifikation af miljøeffektive landbrugsteknologier nationalt og internationalt.

Miljøstyrelsen: Kan man tjene penge på ren luft? - danske styrkepositioner inden for teknologier, der reducerer luftforureningen, udarbejdet af FORA, Miljøprojekt nr. 1203, 2007, 39 sider.

Miljøstyrelsen: Miljømæssige og økonomiske konsekvenser af øgede offentlige grønne indkøb, udført af Cowi A/S, nr. 1218, 2008, 94 sider.

Miljøstyrelsen: Analyse af styrkepositioner inden for teknologier, der kan føre til substitution af kemikalier, Miljøprojekt nr. 1305, 2009, udført af Cowi, 92 sider. 
Miljøstyrelsen: Redegørelse for regeringens indsats for miljøteknologi, oktober 2009.

Miljøstyrelsen: Miljøteknologi på affaldsområdet. Danske styrkepositioner og potentialer, Miljøprojekt nr. 1327, udført af Cowi, 81 sider.

Miljøstyrelsen: Udvikling og godkendelse af low NOx indsprøjtningsdyse til 2-takts dieselmotorer, Miljøprojekt 1361, 2011, udført af MAN Diesel og Turbo, 23 sider.

Miljøstyrelsen: Kort rids af Miljøministeriets miljøteknologiske indsats, 4. marts 2011, 3 sider.

Miljøstyrelsen: Projektlister over årene: 2008, 2009 og 2010.

(Det) Miljøøkonomiske Råd, formandskabet: Vindblæst. Erhvervsstøtte redder ikke klima, kronik i Politiken den 3. april 2011.

Ministeriet for Fødevarer, Landbrug og Fiskeri: Et Grønt Udviklings- og Demonstrationsprogram fremsat den 8. oktober 2009.

Naturstyrelsen: Evaluering af Miljøministeriets handlingsplan for hospitalsspildevand, 13. april 2011, 4 sider.

Oxford research: Evaluering af Energiteknologisk udviklings- og demonstrationsprogram, EUDP 2007-2010, september 2011, 78 sider, og pressemeddelelse af den 19. september 2011, samt faktaark.

Partnerskab for renere Skibsfart. Handlingsplan 2010-2011, 23 sider.

Pressemeddelelse fra Miljøminister Troels Lund Poulsen den 30. oktober 2009.

Pressemeddelelse fra Miljøministeren den 9. februar 2011.

Pressemeddelelse fra Miljøministeriet den 27. maj 2011.

Pressemeddelelse fra Miljøministeriet af den 1. november 2011.

Pressemeddelelse fra Energistyrelsen den 4. juli 2011: 138 mio. DKK til udvikling af fremtidens intelligente elsystem.

Regeringen: Redegørelse om fremme af miljøeffektiv teknologi - vejen til et bedre miljø, maj 2006, 19 sider.

Regeringen: Danske løsninger på globale miljøudfordringer. Regeringens handlingsplan for fremme af miljøeffektiv teknologi, maj 2007, 63 sider.

Regeringen: Grøn vækst, april 2009, 49 sider.

Regeringen: Erhvervsklimastrategi, Globale udfordringer - danske muligheder, oktober 2009, 41 sider.

Regeringen: Grøn vækst, Analyse af Dansk Clean Tech, februar 2010, 14 sider

Regeringen: Grøn Vækst: udfordringer, muligheder og dilemmaer i den grønne omstilling, februar 2010, 35 sider, samt 5 bilag om temaer om grøn vækst.

Regeringen: Miljøteknologi - til gavn for miljø og vækst. Handlingsplan for fremme af miljøeffektiv teknologi 2010-2011, februar 2010, 37 sider.

Regeringen: Energistrategi 2050 - fra kul, olie og gas til grøn energi, februar 2011, 65 sider, plus Sammenfatning på 29 sider, samt en række forskellige bilag.

Regeringen: Reformpakken 2020 - Kontant sikring af Danmarks velfærd, april 2011, 334 sider.

Regeringen: Et Danmark, der står sammen. Regeringsgrundlaget, oktober 2011, 76 sider. Regeringen: Vores Energi, november 2011, 41 sider.

(En) række partier: En grøn transportpolitik 29. januar 2009, 30 sider.

(En) række partier: Bedre Mobilitet, 26. november 2010, 22 sider.

SF: Ny vækst - nye job, 75.000 nye private arbejdspladser, april 2010, 36 sider.

Socialdemokratiet og SF: Fair Løsning 2020 - sammen om Danmark, 94 sider, 16. maj 2011.

Teknologilisten, som opdateret i marts 2011.

Trafikstyrelsens hjemmeside.

Vindmølleindustrien: Pressemeddelelse og notat af den 11. marts 2011.

(De) Økonomiske Råd: Diskussionsoplæg: Trafikstøj, Energi- og Miljøforskning, og Afgifter og klimamål. 23. februar 2011, 300 sider. 
Aarhus Universitet: Oversigt over miljøteknologier i det primære jordbrug - driftsøkonomi og miljøeffektivitet, juni 2011, 60 sider.

\section{Finland}

Clean Tech Finlands hjemmeside.

Clean Tech Finland: Innovative technologies for clean environment 2007, 16 sider.

Clean Tech Finland: Internt notat, november 2011, 2 sider.

European Commission Environment's hjemmeside.

(Den) Finske Ambassade, London: Finsk skovindustri godt eksempel på udvikling af renere teknologier, (her på dansk) 12. juli 2011, 2 sider.

High Tech Finland: hjemmeside om eksempler på energi og miljø, langt over 100 eksempler.

Jukka Noponen: Finnish Cleantech market development, 5-6 juni 2006, indlæg på Cleantech Forum Lahti, 8 sider.

Jukka Noponen: Sitras environmental programme - Clean Tech Finland, indlæg den 15-16 november 2005, Skt. Petersburg, 3 sider.

Ministry of Employment and the Economy, Erhvervs- og Byggestyrelsen, Fora and OECD: New Nature of Innovation, September 2009, 96 sider.

Ministry of Employment and the Economy: demand and User-driven Innovation Policy - Framework (part I) and Action Plan (Part II), august 2010, 102 sider.

Ministry of Environment: Ekoinnovaatiot ja ympäristöpolitikka. Rapportti ympäristöinnovaatiopaneelin toiminnan tuloksista ja jatkotoimenpiteiksi (Eco-innovation and environmental policy. Report of the environmental innovation panel and recommendations for further measures), marts 2011, 39 sider.

Ministry of Environment: facts on environmental protection, case om Wetend Technologies Ltd., maj 2007, 2 sider.

Ministry of Environment: facts on environmental protection, case om Biolan Oy, maj 2007, 2 sider.

Ministry of Trade and Industry: Finlands national RoadMap for the implementation of the Environmental Technologies Action Plan for the European Union (ETAP), januar 2006, 33 sider.

Nordic Cleantech Open, Lahti science and Business Park: Finnish Cleantech Venture Report 2011, 14 sider.

OECD: Environmental Performance Reviews: Finland. 2009.

Petri Peltonen: Ministry of Employment: Government input in boosting innovation in the field of Environmental Technology in Finland, marts 2008, indlæg på 15 overheads.

Pressemeddelelse fra Sitra om energiprogrammet I 2008, samt en lille folder fra Sitra herom.

Pressemeddelelse fra Tekes om programmet for grøn vækst etc., den 19. januar 2011.

Sitra: Environmental programme, Finland, 2005, 7 sider.

Sitra: Clean Tech Finland - improving the environment through business. Finland's national action plan to develop environmental business, januar 2007, 44 sider.

Sitra: A natural Resource Strategy for Finland: Using natural resources intelligently, april 2011, 12 sider.

Statsrådet: Finlands strategi för et hållbart Finland. På väg mot hållbare val, Et nationelt og globalt Finland. Statsrådets kanslis publikationsserie, 2/2008, 136 sider.

Statsrådets framtidsredegörelse om klimat- og energipolitiken: vägen till ett utsläppsnålt Finland. Statsrådets kanslis publikationsserie 29/2009, 190 sider.

Statsrådskansliet: Bioøkonomi: vurdering af behovet for en national strategi, på finsk, 2011.

Statsrådets kansli: Regeringsprogrammet för statsminister Jyrki Katainens regering, 22. juni 2011, 100 sider. 
SYKE: Increasing eco-efficiency - an analysis of the factors generating innovations (Ecoinno).

Tekes: Towards green growth? - The position of Finland in environmental technology, april 2011, 61 sider.

Tuomo Nikulainen: Towards a green post-crisis economy? - Finnish opportunities in environmental technologies. Overheads from Ministry of Environment - Tekes seminar, 8. December 2010, 17 overheads.

Turku School of Economics and Business Administration/Pävi Keskitalo: Internationalisation of Finnish Environmental Technology to Poland, 2006, 53 sider.

Työ- ja elinkeinoministerio (Arbejds- og næringsministeriet), og Ministry of Employment and the Economy: Edelläkävijämarkkina-aloite ja innovaatiotoiminta (Innovation policy and the Lead Market Initiative for Europe), august 2010, 146 sider.

Ympäristöministeriö: Sääntelyn ympäristöinnovaatiovaikutukset, (Reguleringens indvirkning på miljøinnovationer) februar 2011, 34 sider.

\section{Island}

Althinget: Lov nr. 152/2009 om støtte til innovation i erhvervslivet (på dansk), se althingets hjemmeside.

Althinget: Lov nr. 87/2003 om Energifonden og Forordning om Energifonden.

Clean Tech Iceland: A Vision for Success. Draft, februar 2011.

Enexs hjemmeside.

Fjárlagavefurinns hjemmeside.

Fjármálaráduneytid: ministerens artikel af den 10. november 2011: Innovation i erhvervslivet.

Grøn indkøb (VINN), 2011, se grøn indkøbs hjemmeside.

Hagstofa Islands: Ændringer I det harmoniserede forbrugerindeks (HICP) siden 2005, se hjemmesiden.

Hákon Gunnarsson og Thora Margret Thorgeirdóttir: Merværdi I geotermisk varme. Den islandske klynge. Rejse og vejviser (titel oversat til dansk), september 2011.

IMPRAs hjemmeside.

Industriministeriet i Islands hjemmeside.

Industriministeriet: Den grønne energi - økoenergi i transport (på dansk), 2010.

Industriministeriet: Sådan når vi målene. Projektstyrelsen for den grønne energi afgiver sin rapport til ministeren. Nyhed på hjemmesiden den 22. november 2011.

Industriministeriet: Grøn energi - økoenergi i transport: Udveksling af energi i transport. Policy, målsætning og handlingsplan (på dansk), november 2011.

Innovation Center Islands hjemmeside om miljø- og energiteknologi.

Innovation Center Islands hjemmeside om tilskud og støtteprojekter.

Innovits hjemmeside.

Islands Industriforbund (SI), Bryndis Skúladóttir: e-post af den 29. november 2011.

Islands parlaments udvalg for fremme af grøn økonomi: Fremme af grøn økonomi i Island. Bæredygtig velstand - et samfund som forbillede (på dansk), 2011.

Islands regering: Statens politik om grønne offentlige indkøb. Staten som en informeret grøn indkøber, 2009.

Islands statistiks hjemmeside.

ISORs hjemmeside.

Jardboranirs hjemmeside.

Löggjafarthing 2009-2010, 138, Tillage til thingsályktunar, 6 sider.

Miljøministeriet: Velfærd for fremtiden - Bæredygtig udvikling i det islandske samfund - Strategi til 2020 (på dansk).

Miljøministeriet: Velfærd for fremtiden - Bæredygtig udvikling i det islandske samfund - Fokusområder 2010-2013 (på dansk). 
New Business Venture Funds hjemmeside.

Nordisk Innovationscenter: Workshop on Nordic Environmental Technology - Innovation and Export, Oslo, Norway, March 29-30, 2006, 21 sider.

Orkustofnuns hjemmeside.

Pressemeddelelse fra Industriministeriet om samarbejde med Rwanda, den 24. november 2011.

Pressemeddelelse fra Miljøstyrelsen i Danmark: Clean Tech-prisen går til biomasseovn, se Miljøstyrelsens hjemmeside.

Rannis hjemmeside: Teknologiudviklingsfonden.

Remake Electrics hjemmeside.

Samtök Idnadarins: Carbon recycling begynder med produktion af miljøvenligt brændstof, nyhed på hjemmesiden den 18. november 2011.

Velferdarraduneytid: Lanatryggingasjodur kvenna endurvakinn. Se kvindefondens hjemmeside den 8. marts 2011

Vidskiptabladids hjemmeside.

\section{Norge}

Cicero report 2007:05: Planlagt etablering av Klimafond - diskusjon av formål, anvendelse og effekt, oktober 2007, 18 sider.

Econ: Virkemidler for å fremme miljøteknologi. Rapport 2006-019, 2006, 72 sider. Econ Pöyry: Rammeverk for utvikling af miljøteknologi, februar 2010, 70 sider.

Forum for Miljøteknologi: Regjeringens miljøstrategi, 21. juli 2010, 3 sider.

Innovasjon Norge, Norges Forskningsråd og Statens Forurensingstilsyn: Miljøteknologi, forslag til samarbeidsmodell og tiltak fra 2008, april 2007, 11 sider.

Innovasjon Norges hjemmeside: Miljøteknologiordningen 2010 - projekteksempler, 2 sider.

Klimakur 2020: Tiltak og virkemidler for å nå norske klimamål mot 2020, marts 2010, 316 sider.

Menon: Miljøteknologi. Potensial og hindre for utvikling av norske konkurransedyktige bedrifter, mai 2009, Menon-publikasjon nr. 7, 108 sider.

Menon: Miljøteknologi og nasjonale fortrinn. Miljøteknologiområder i Norge med potensial for internasjonal vekst, januar 2010, 67 sider.

Menon Business Economics: Miljøteknologi i Norge, november 2011, 26 sider.

Miljøverndepartementet, Fornyings- og Administrationsdepartementet, og Barne- og Ligestillingsdepartementet: Miljø- og samfunnsansvar i offentlige anskaffelser, Handlingsplan 2007-2010, juni 2007, 36 sider.

Norway's National road map, Enviromental Technologies (Follow-up of the EU Environmental Technologies Action Plan, ETAP), 2006, 14 sider.

Nærings- og Handelsdepartementet og Miljøverndepartementet: Næringsutvikling og grønn vekst. Regjeringens strategi for miljøteknologi, 05/2011, 46 sider.

Statens Forurensningstilsyn: Miljøteknologi - hvordan kan Norge bli et foregangsland? Miljøgevinst hjemme og ute, verdiskapning hjemme, juni 2007, 25 sider.

Statens Forurensningstilsyn: Mål og sukceskriterier for en nasjonal strategi for miljøteknologi, Notat af den 15.05.2009, 32 sider.

Stortingsmelding nr. 21 (2004-05): Regjeringens miljøpolitikk og rikets miljøtilstand. Stortingsmelding nr. 26 (2006-07): Regjeringens miljøpolitikk og rikets miljøtilstand. Stortingsmelding nr. 7 (2008-09).

Teknologirådet: Bærekraftig innovasjons- og teknologipolitik, rapport 2, 2005, 56 sider. Teknologirådet: Et norsk fond for klimateknologi, januar 2011, 20 sider.

Tor-Petter Johnsen: Grønne penger. Et udvalg offentlige økonomiske styringsmidler for miljøteknologi i 10 land, 10. maj 2009, 55 sider.

Trond Giske: Overheads om tilskudsaktiviteter i Innovasjon Norge, 30. marts 2011. 
Øyvind Lone: Norsk miljøteknologi: Noen eksempler og erfaringer, maj 2011, 90 sider.

\section{Sverige}

Cleanindex hjemmeside.

ITPS, Instituttet för tillväxtpolitiska studier: Svensk miljöteknik. En kartlägning av aktörer, marknader och konkurrenter, juni 2008, 123 sider.

Jordbrugsdepartementet: Jordbrugsprogrammet 2007-2013, 2010, 372 sider.

Kommittédirektiv 2008:31 Sveriges miljöteknikråd - en delegation för miljöteknik, 3 sider.

Naturvårdsverket: Exemplets makt. Utvärdering av hur arbetet med goda eksempel fungerar i miljöarbetet. Rapport 5259, december 2002, 74 sider.

Naturvårdsverket: Lokala miljöinvesteringer ger globale avtryck, februar 2008, Rapport 5806.

Näringsdepartementet: Kommittédirektiv: Organisation av ett nationellt centrum för miljödriven näringsutveckling och miljöteknikexport, Dir. 2004:25, 5 sider.

NUTEK. Nationellt centrum för miljödriven näringslivsutveckling och miljöteknikexport - ett förslag från NUTEK, april 2003.

NUTEK: Nationell kraftsamling för miljödriven näringslivsutveckling - ett förslag från NUTEK, november 2003.

Proposition 2011, 12:1

Regeringen: Strategi för utveckling och export av miljöteknik 2011-2014, 1. september 2014, 13 sider.

Regeringskansliet: Miljötekniklösninger - 13 svenske eksempel, september 2011, 32 sider.

Riksdagen: Rapport fra Riksdagen: Uppfölgning av statens stasning på hållbare städer, Stockholm 2010, 295 sider.

SCB: Miljöräkenskaper. The environment industry in Sweden 1999, rapport 2000:1, 48 sider.

SOU: Delegationen för Hållbare städer, Miljövårdsberedningen jo 1968:a, 115 sider.

Svenska Instituttet: Hela listan med Sveriges 20 hetaste innovationer, 2 sider.

Swentecs hjemmeside.

Swentec AB - för en nationell kraftsamling på svensk miljöteknik, SOU 2004: 84, 155 sider.

Swentec: En kartlägning av svensk avfallshandtering och återvinning - Spjutspetskompetensen, marts 2008, 74 sider.

Swentec: Swedish strategies and initiatives for promotion of environmental technology. A National Roadmap for the implementation of ETAP, December 2008, 73 sider.

Swentec/SCB: Svensk Miljöteknik i siffror 2009, Statistik och analys för den svenska miljötekniksektorn, 11 sider.

Swentec: Rapport til regeringen maj 2009. Vägen mot en effektiv struktur för svensk miljöteknik, maj 2009, 29 sider.

Swentec: Swedish Waster Offer, Etapp 1, december 2009, 34 sider.

Swentec: Offentlig upphandling som ett strategisk verktyg. Miljöteknikföretagens konkurrenskraft, december 2009, 17 sider.

Swentec: Handlingsplan för svensk miljöteknik, december 2009, 82 sider.

Swentec: Framtidens miljöteknik. Innovationer från de kundskabsintensiva spetsområderner IT, bio-, rymd och nanoteknik, november 2010, 138 sider.

Swentec: Exempelsamling - företag, produkter och verksamheter. Kompletterande material til Swentecs rapport „Framtidens miljöteknik“ fra november 2010, 20 sider.

Swentec: Slutbetänkande av Sveriges Miljöteknikråd N2008:2, november 2010, 19 sider. Technopolis: Utvärdering av Miljöinriktad fordonsforskning, juni 2011, 23 sider.

Teknik360: Swentec stänger butikken, artikel af Jonnie Wistrand, november 2010. 
Teknikmarknad: Notat om tilskudsmidler, november 2011, 13 sider.

VINNOVA: Forskningsstrategi för miljöteknik. Redovisning av regeringsuppdrag til Formas og VINNOVA, juli 2007, 245 sider.

VINNOVA: Framtid med växtvärk. Kan hållbare städer möta klimatutmaningarna?, 2011, 80 sider.

VINNOVA: Miljöinnovationer - projektkatalog, januar 2011, 54 sider. 



\section{Summary}

\subsection{Introduction}

The purpose of this publication has been to describe the Nordic countries' efforts to promote eco-efficient technology or environmental technology. The emphasis in this description has been on the solutions of environmental problems rather than the focus on the business potential. The central goal was to assess the status and look at possibilities for improvement for each country. But it has also been interesting to look at differences and similarities of the Nordic countries in between, and to assess whether there are opportunities for better cooperation to move forward by the help of others.

Based on the EU Commission's initiative for a common EU Environmental Technologies Action Plan from 2004, activities in the individual Nordic countries, i.e. Denmark, Finland, Iceland, Norway and Sweden, for the years 2004-2011 are described. Preferably with forward looking perspectives, if possible.

The intention was to collect the written and formulated materials from each of the Nordic countries and draw a picture of what has happened and is happening in each country. Against this background, questions were formulated for each country on what material and initiatives were available, for the instance: strategies, grants/subsidies, promotion of demand, etc. The focus has been on the number of firms and the export of these companies, as an indicator of the international strength. Following this there are descriptions of activities and reports from individual countries and not least strategies and grants/subsidies in the countries in the field of eco-efficient technology or environmental technology. A special section describes activities on the demand side in each country, and there is also a section on examples of companies with international success. Finally, each country section is closed by a conclusion.

Described below, after some brief remarks on general trends, each country is mentioned with a brief summary of the conclusion section of the country. Further details are available of course, by reading the detailed examination of the country and conclusion section of this review. The report tries to keep a fairly uniform disposition from country to country. This is however not possible since there is a big difference in what countries have done concretely and not least of which and how much material is available in the countries. The countries are listed alphabetically. 


\section{Trends}

It seems almost impossible to get a binding international climate agreement to succeed the Kyoto Protocol. At the same time there are reports from the UN IPCC and IEA, which show that it is getting warmer faster than has been anticipated. It becomes almost impossible to keep a 2degree limit on increase in temperature, and even now there are assessments on an increase of up to 6 degrees by 2100. Reports also show that $\mathrm{CO} 2$ emissions globally continue to rise and extreme weather becomes more likely.

In this situation of global paralysis it is obviously very important that individual countries and groups of countries should go ahead and show that it is possible to reach new achievements in innovation and implementation, and thereby reducing emissions. Some mutual helping hand between these countries may prove to be valuable and even more valuable than you might imagine.

Another trend that should be highlighted is the talk about green growth and green economy. Eco-efficient technology or environmental technology already seems to be a slightly outdated topic. Green growth or green economy takes over with great interest from many governments. As explained in the introduction, green growth and green economy is a comprehensive approach, while eco-efficient technology can be seen as a subcategory under green growth and as such a part thereof. It must be considered positive that there is an interest for a broader approach, but the weakness is that the focus becomes difficult to keep in eco-efficient technology. It becomes uninteresting in the public and governments eyes, although there is a need for stability and continuity, in order to have success in development over time. In trying to achieve success with eco-efficient technology nationally and internationally, it is necessary to consider the interest in green growth as a very positive wave. It can provide the basis for a more systematic development.

In this context, the EU Commission's changing terminology also creates some confusion about where we are going and what's important. Strategic change may lead to a lack of continuity and confusion about the way forward.

A third trend or observation may be said to be that the topic is constantly evolving with new examples, reports, strategies and actors. This makes it difficult to maintain the focus of the analysis. Situations are constantly changing. The project is thus an expression of the status in the Nordic countries each as on 1 December 2011, which sets the end of the project.

Overall, one must say that the amount of material, actors, decisions and examples have exploded in recent years. This makes it almost impossible to find a clear way into an area as eco-efficient technology or environmental technology, which seems to have many followers and hence high possibility of success. With success, not least extra grant funds, companies send many signals on innovation, promotion, etc. 


\section{Denmark}

In Denmark the sector of eco-efficient technology is around 500 companies. Exports can be estimated to 85 billion DKK in 2010 with 55 billion DKK to the energy sector, which is rather certain and a very uncertain amount of 30 billion DKK for the environmental sector. However, there is quite a large need for improvement of statistical work. The Energy Agency and The Environment Protection Agency should be central in this work respectively for climate/energy and environment, though other players may well be the main drivers.

Denmark made in 2007 an overall governmental strategy for ecoefficient technology, which soon turned out not to make it all in all, as climate/energy was separated from the Environment Ministry and a new climate and energy ministry was formed. After this there have been two roads, a climate/energy focus and an environmental focus.

The climate/energy effort is the largest and most exciting venture in Denmark with grant funds to just over 1 billion DKK in each of the years 2010 and 2011. The magnitude appears to continue even though the largest program, EUDP, gets a little less in 2012. Climate/energy has reached a nice shape with a combined annual report for the many programs that exist in Denmark. The interesting thing about climate/energy is of course also the increasingly direct target of a society free of the use of fossil fuels, which drives or compels innovation forward. Of course, economic instruments and substantial regulation have to be used to achieve these results.

Environment has actually been stronger in 2008-2009 than in 201011, where there have been relatively fewer resources and less strategy. Now it is decided to make an Environmental Technology Development and Demonstration Program (MUDP) from the beginning of the year 2012, taking inspiration from the more successful climate/energy field. Perhaps there can now be a focus on larger projects, preferably in collaboration with other programs in Denmark.

The two other funds in Denmark, GUDP in agriculture and Fornyelsesfonden first really started in 2010 and have not shown many results yet.

A main recommendation for Denmark is that the climate/energy area should do its generally excellent work better with more information to the public, as well as a clearer linkage to the Danish targets or goals on climate change. The other areas i.e. MUDP, GUDP and Fornyelsesfonden should be able to help each other to promote a more cohesive effort in the field of environment.

\section{Finland}

In Finland numbers on companies seems at the best to be around 400 companies maybe more. Clean Tech Finland claims, however, the number to be 2,000 companies, lacking convincing statistical basis for this statement. The sector is estimated to have a turnover of $12-17$ billion 
EUR in 2010. This figure Clean Tech Finland estimates to be 18 billion EUR. In 2006 it was estimated that exports could be set at 2.25 billion EUR, while the Clean Tech Finland gets this figure to 13.5 billion EUR in 2010. Against this background it is reasonable to conclude that there is a great need for numerical data that can provide a better understanding of the sector's size and what is really happening. A state authority should be linked to such figures annually to ensure continuity.

The independent Finnish innovation fund Sitra, has promoted the field forward in a number of years. Sitra made in 2007 Finland's first action plan for environmental technology, the vision was that Finland would be the best known cleantech country in the world in 2012. Sitra demands in its draft strategy, a strategic owner of the Action Plan, which can only be the government. The Finnish Government is responding only indirectly by mentioning environmental technology as an area of priority.

It may be mentioned that Finland is perhaps the world's strongest research and innovative country. Work on research and innovation is very strong in Finland. They have also worked more than the other Nordic countries, with user-driven innovation, including environmental technology, as a means to promote innovation. Finland is working more closely with the demand side than the other Nordic countries by for instance publishing a report on regulation as a demand driver. Finland has also focused more on patents than the other Nordic countries.

The closest we get a new strategy for environmental technology in Finland is the Finnish funding agency for research and innovation, Tekes' publication on green growth - Finland's position in environmental technologies. Discussions on green growth and green economy have already been going on in Finland for a few years. Tekes concludes that Finland needs a clear strategy and a clear policy on green growth and environmental technology. Tekes' report bodes well for the future of environmental technology in Finland, but it must of course be implemented. Although the government is working with several promising initiatives on bio-economy, natural resources and mentions ambitions in the environmental technology fields, there is a need for a clearer overall government's announcement from the Finnish Government. This need not be any larger work, but may well be in the form of a small publication as in Sweden.

\section{Iceland}

In Iceland, it is estimated that there are just over 40 companies, which can be counted with the group of environmental technology companies. Over half of these companies work with energy, including 8, specializing in geothermal energy. Annual turnover is estimated to be 700 million DKK and the number of employees can be set at approx. 1,200, while exports may be set at 325 million DKK in 2010. The figures are very uncertain, but better than any other information up till now in Iceland. There can be no doubt that there is a great need in Iceland to get a more 
continuous mapping of the area every year. This applies not only to statistics about the sector, but also analysis of subsectors. Here, we have seen an analysis of the geothermal sector, which bodes well.

The state actors in Iceland have shown little interest in eco-efficient technology or environmental technology related to the EU ETAP, etc. They have not done very much other than considered environmental technology, like any other kind of innovation and development. Interest has come from a number of companies who have seen the potential for development.

With parliament's work in green economy and the report on the topic, Iceland has however taken a huge step forward. No other Nordic country has made such a detailed report on the green economy, which is remarkable. Thus Iceland has in a way brought itself on line or at least a big step forward from having ignored the area reasonably long. The other Nordic countries should be interested in the report on the green economy, when it will be published in English. One can hope that Iceland's government will implement all recommendations in the report in an efficient manner.

Iceland has a very unique situation internationally with large geothermal sources. Already now it exploits the geothermal sources for electricity, and there is even a large amount of power lost in the actual utilization. So much larger utilization can probably be achieved. Internationally there is a limitation of exports, etc., because most countries do not have the same geothermal conditions as Iceland. Iceland's energy should also be used to promote an advanced environmentally friendly transport. It can be done much better with more focus than today. In this area, and other side effects from geothermal sources, Iceland seems to have great potential to develop into an interesting environmental technology country.

Also overall seen, as it might be the first $\mathrm{CO} 2$-neutral society in the world, Iceland can reach very far. It is obviously a discussion about how to take on that task. It is understandable that Iceland wants to attract the production of aluminum, which can be produced cheaply by taking advantage of cheap energy. In such situations one must assess how to achieve the best overall solutions.

In addition to implementing recommendations from the report on the green economy, the Icelandic government should develop a strategy and a long-term action plan for promotion of environmental technologies. This is probably the most important recommendation for Iceland. In addition, these activities could be implemented efficiently with better and more targeted subsidy systems, better use of economic instruments and promoting demand where it makes sense in a small country like Iceland. 


\section{Norway}

In Norway, the number of companies in the environmental technology sector amounted to approx. 300 in 2011. They have a turnover of 18 billion NOK and 6,000 employees. Exports amounted to 6.7 billion NOK in 2010. This export statement is based on 114 companies and is considered to be reasonably conservative. Export figures may well be greater. There should in Norway be a strengthening of statistics for environmental technology, both in number of firms and exports, and preferably also subdivisions to give the best picture. A state actor should get involved in this statistical work, or assigned for this purpose. It should at least have a greater attention.

In the period 2004-2007 most focus on the area in Norway were at the so-called environmental technology project under Statens Forurensningstilsyn, where Statens Forurensningstilsyn, Innovation Norway and the Norwegian Research Council worked together to develop the area. Development work continued during the next period from 2008-2011 with the Strategic Council for Environmental Technology with several reports of a generally high level of quality.

As crucial for Norway's efforts one must mention the government's new strategy for environmental technology in 2011. The strategy is based on a number of good reports on environmental technology, which has been developed in Norway. It has a qualified drafting with focus on 6 core dimensions and a program of environmental technology with an additional allocation of 500 million NOK over 3 years, mainly in Innovation Norway. This strategy starts a new phase of work on environmental technology in Norway.

In Norway, there are 3 players of subsidies/grants: Innovation Norway for larger subsidies, like demonstration projects, Norwegian Research focusing on research and a series of research networks, and Enova, which is active in energy.

A main recommendation for Norway is to build or implement the new strategy into an excellent platform so that Norway can improve on environmental technology to fulfill its ambitions. However, quite a lot has to be done: better track of statistics, technology areas, instruments and initiatives etc., so there may be more coherence between policy statements and instruments or efforts.

\section{Sweden}

In Sweden there has been quite a lot of focus on the figures of the sector of environmental technics, which is the concept used in Sweden. The total number of firms was calculated at 6,500 in 2009, although including a large number of one man companies. There are estimated to be approx. 40,000 employees with a turnover of 119 billion SEK. Exports for 2009 are estimated to be 40 billion SEK. Without a doubt a good statistical base is available in Sweden to make a better assessment of the number of companies. The new Swedish strategy speaks of some hun- 
dred companies. This can probably be 400-500 companies in view of Sweden's economic size. Tillväxtanalys - myndigheten för tillväxtpolitiska utvärderinger och analyser has now been given the task to improve the Swedish figures.

As a special feature in the Nordic countries, Sweden has created a special unit to promote environmental technologies, Swentec, a Swedish Environmental Technology Council. Swentec was established in 2005 and was closed by the end of 2010. Swentec had an annual budget of 1012 million SEK and the last year, 7 employees. Overall, one must say that Swentec has managed to lift the work in Sweden on environmental technology with a wide range of activities. Swentec have even made a draft action plan in this area. It seems clear that an area can be brought forward successfully with such a central unit only focusing on that task. In a way, it is not an advantage for Swedish environmental technology that Swentec was closed. Hopefully, the new strategy will be sufficiently focused so that it is able to lift some of the work Swentec has done.

From the Swedish effort it is worth especially to mention sustainable cities, an effort unique among the Nordic countries. No other country has taken the task of promoting sustainable cities by creating a special program for this. There is quite a lot of work on sustainable cities, both from the delegation itself, from the parliament, but also from VINNOVA, who made a special report on the prospects of working constructively with sustainable cities. The other Nordic countries could really learn something from Sweden in this difficult area.

The Swedish government published its new strategy for environmental technology on 1 September 2011. It is even called a strategy for development and export of environmental technology. The strategy includes especially the international side and exports. The strategy is short in a positive way and focused on several key areas. There are not many recommendations compared to what Sweden has previously worked with, which certainly is an advantage. It must be implemented, and there appears in this sense, among other things to lack a clear center of responsibility for the strategy. However, there has been a very clear Government announcement on the solution of responsibility, and in this understanding it still lacks a clearer division of labor between state actors.

\section{Eco-efficient technology and/or environmental technology}

The project started to use the concept of eco-efficient technology as the English term "eco-efficient technology" is based on the EU ETAP work. This was determined from the perception that eco-efficient technologies are better able to accommodate also climate and energy, while environmental technology probably is perceived as more old-fashioned. This analysis shows that all the Nordic countries are very influenced by the ETAP action and highlights that the way they use the concept is in accordance with ETAP. This makes it clear how central the EU's activities are. They affect member countries substantially and also countries like 
Norway, which largely follows the EU-commission activities. Hopefully ETAP will have sufficient power to renew the process.

It turns out that Norway, Finland and Iceland use the concept of environmental technology, Sweden uses environmental technics and Denmark is the only one who uses eco-efficient technology, even though Denmark used it consequently only early in the period 2004-2011. Now Denmark also often uses the concept of environmental technology. Therefore, the conclusion is that in the Nordic countries most often the concept of environmental technology is used. This is also acceptable, as long as it also includes the understanding of climate and energy, which it often does. It seems not to be the case though in the field of climate and energy, where people often use the term climate and energy technology. It would probably in any case be difficult to get the back up of all actors in the Nordic countries for the same concept. Therefore we must conclude that the use of a common concept can be environmental technology as well as eco-efficient technology.

The cleantech term is used too, typically in international contexts, because this concept is perceived as more modern or maybe even more smart. Many associations or networks of companies call themselves Cleantech Network. It seems more modern and more international.

\section{Companies}

The number of companies and the number of employees, turnover etc. in eco-efficient technology is quite interesting because it indicates how much of the economy that may be linked to this sector. Moreover, it is important if a country wants to invest in an area, that it knows exactly on what background this is being done and do not work with a wrong impression of the sector. There are examples of misunderstandings of trends or waves, for example, the IT bubble, biotech interests, that do not seem to have enough substance, etc. It would be very unfortunate if eco-efficient technology or environmental technology, green technology proves to be a loose idea that is not very solid over time. Therefore, a solid statistical basis, important use of policy instruments, etc. is very important to the implementation of a good strategy. No one can have an interest in exaggerations over time. It will only work for a short period of time.

It is not easy to calculate the number of firms because previous statistics cannot handle eco-efficient technology as an industry. It is a sector that cuts across many industries and areas. This is difficult to handle, but includes perhaps also some more interesting aspects, since it is quite extensive.

So it is quite difficult to define which companies to include in the sector. What about the Finnish company KONE's super modern elevator system, which uses much less energy than the previous one? How should this technology be taken into account? It is obviously a very efficient technology seen in energy technology perspectives. KONE's pamphlet is impressive reading. It would though be intimidating for the definition, if 
all new products that have become very energy efficient, must be included, as nearly all new products often have far more energy efficiency than the products they replace.

There are also many other problems of demarcation. Should small companies be included? Most will probably say that one man companies might not be included. They might confuse the picture. You could put a reasonable limit by 5 employees, so it makes sense. There is also the problem of environmental weighting of companies, such as practiced in Norway. This is particularly relevant for parts of larger company activities and is highly recommendable.

The report estimates the number of companies in Denmark to be approx. 500, Finland to have over 400 companies, Iceland to have 40, Norway to have 300, and Sweden to have maybe 600 companies. These figures are highly uncertain, since there are many statements in the countries. In Denmark there are even different statements from the same consulting firm and in Finland a persistent bid for 2,000 companies.

There is also a tendency for business associations in the countries to calculate too many companies to be included in the sector of ecoefficient technology. This can only be interesting for interest organizations. It is so much "in" to be cleantech and information thereon explodes. It will often pay for companies to market themselves in the field of eco-efficient technology or environmental technology.

In general, it is highly recommendable to create an annual statistics of firms in each country. As a minimum, one must explain how it is defined or delimited. Otherwise you cannot understand from the outside, what criteria have been used. The annual statistics, or at least as a basis, there should be a public list of company names, so that you do not have to re-establish over and over again such a confidential list in a new consulting firm, which explores the area. It is important that a government institution has the monitoring task for this.

It is also important to try to break down each area within the sector. Only this will get a better focus on specific areas in need of such a focus to develop. One can use a simple approach, so that the numbers of areas do not explode. A useful and fairly simple approach may be that from the Danish consulting company Brøndum \& Fliess. This consultant company divide eco-efficient technology or cleantech, which is the term used as following: first, they divide the sector into two areas: one for energy and one for environment. Then each of the two areas is divided into 4, namely energy: green energy production, efficiency of energy use, energy infrastructure, energy storage, and environment: sustainable materials, waste and recycling, water and wastewater, air and environment. For a more detailed description, see the consultant report. One can of course have an extra category in both energy and environment in order to include other areas which might not be included logistically. One might mention for instance CCS in the energy field and soil remediation in the field of environment as such special cases. 
One should also not hesitate to analyze other areas or cross-cutting areas such as: sustainable cities, agricultural technologies, wood burning stoves, membranes, electric cars, hybrid cars, etc. Good research is a large advantage and is highly recommended. It provides an overview and understanding of how to promote development through the use certain instruments.

\section{Export}

Exports of eco-efficient technology is selected as a clear indicator of how strong a country's international activities are in the area. Denmark is estimated in 2010 to have an export of 85 billion DKK, 55 billion to the climate/energy area and 30 billion to the environment area. Finland is estimated to have an export of approx. 13.5 billion EUR in 2010. Iceland is estimated to have an export of 325 million DKK in 2010. Norway is estimated to have an export of 6.7 billion NOK in 2010. In Sweden exports amounted to 40 billion SEK in 2009, but it may well be larger. The fact that Denmark has a large export is mainly due to the wind industry, which is very big in Denmark. Finland has the largest export, which is a number that comes from Clean Tech Finland.

It is extremely important that one can determine the level of exports reasonably accurate. With this figure one has a good possibility to assess how you stand internationally. Focus can of course also be on imports, which are often taken as a weakness of a country and therefore it is often tried to promote home players to produce products that are imported. Discussions in Denmark can illustrate how difficult it is when multiple players try to assess sizes in exports. Here are assessments collected on climate/energy and the environment. Climate/energy seems to have found some common ground, but there is still work to be done in the field of environment where a solid basis is lacking. If you do not have a player for the whole sector, which accounts for the statement, such as in Sweden, it is advantageous to split the export statistics into a climate/energy component and an environmental component. In splitting these two areas remember to avoid any overlap between the two areas.

It is also important that there is a state actor, who has ultimate responsibility for export numbers and ensures an annual review. So continuity and openness of the figures are central.

Patents another area in which it may be interesting to assess a country's strength, is the number of patents obtained. If one examines the number of patents over time e.g. in the period 2000-2011 one can get a good overview of how strong a field you are dealing with. You can both calculate for the whole area of eco-efficient technology, or for parts or groups of companies. It gives a clear picture of where the companies have an international position of value. The review of the Nordic countries shows that only Finland has done this systematically, as mentioned in Tekes' new strategy for Finland's position in environmental technolo- 
gies: Towards Green Growth? Here an estimate of the number of patents is used to say something about strength.

It should, on this basis, be recommended that each of the Nordic countries should try to calculate the number of patents as an indicator of the international strength.

\section{Grants/subsidies}

Grant funds are probably the most central instrument that all countries use to promote the development or implementation of eco-efficient technology. In the questions to the countries there has been considerable focus on the amount of grant funds, grant areas, program management, performance, etc. It turns out that when a funding package is approved and money allocated to a grant administrator, this decision is rarely followed up with demands on management, reporting, evaluation, etc. If this is systematically implemented anyway, one must conclude that it is automatically implied by the general administration of the responsible institution. It's certainly not something institutions inform in general to the public.

There were at project start an expectation that it was possible to establish lists of areas and sizes of grant funds, results, etc. It turns out quickly that the countries are not particularly good at creating this overview. So it's not something that is particularly accessible, and this project has not succeeded to find material, where grant funds size etc. is described in great detail. Each country section shows figures from the strategies and announcements of future actions, but it has not been possible to create this picture back in time. This is unfortunate and should be done better in the future if more information on grant funds can be provided.

Are there sufficient grant funds? Sometimes a report states that there are sufficient funds, other times there are statements about the lack of funds. There are funds available in all Nordic countries. They could certainly be larger, when most programs show that companies apply for more funds than are available. On the other side, it is clear that you should not just offer funds in a very easy way. It should not be too easy to get the funds, because the consequence might very well be lack of results. Generally, one might say that it should be pretty easy to allocate more grant funds, as they usually are small amounts in overall size compared to many other areas of state expenditure.

Grant funds may go to a number of purposes: research, development and demonstration are mentioned frequently as three goals in a chain of development. Such a chain of development is often more detailed. There is no doubt that research frequently has received the most funds. The EU has also had certain reluctance towards funding for demonstration projects because it is considered to be too close to the general understanding of state aid. This seems fortunately to belong to the past in that the EUcommission also has accepted that there must be enough financial resources to demonstrate technologies in the real world and not only on the 
drawing board. First late in the period 2004-2011 there has been more focus on the demonstration activities, which requires that the technologies will come to proper testing. And it must also be said that if you have no financial resources for demonstration, many technologies cannot be tested in reality. Therefore, one should always ensure that funds are available for demonstration activities, actually abundant funds.

Generally speaking, there are only few demands for grant administrators from grant authorities. Grant administrators do in general have quite large degrees of freedom in how to proceed. The minimum requirements should be information, communication and evaluation in addition to the activities normally taking place on securing that grant funds are sensible used.

One area worth to mention is the way in which grant funds are announced. This happens almost always as applications from companies and not by official tenders. There are often formulated themes or areas of technology that can get support, but the provider of funds seldom go very far setting details for these themes. This is probably due to the fact that it can be quite difficult to formulate specific requirements. Nevertheless, one might describe areas of technology, using experts to formulate a tender that companies should offer. It obviously takes time and costs money. The overall recommendation to grant administrators is that they must work with the perspectives and details, and not only provide funding for applications without having detailed knowledge.

Something that also makes it difficult to investigate grant funds is the time the grant for a project is announced and the time for the disbursement of funds. Typically, the grant giver pays for work done and not at the beginning of the project. This means that the money is transferred during or after the work has been performed. This makes it sometimes difficult to follow the use of the funds. And this often leads to misunderstanding about how many resources are used. It would be helpful that for each year lists of available funds are presented. This baseline can be used and a better approach can be established than if different phases of the projects are used. Then evaluations can show how much has been spent.

Especially for a country's own sake there should be a good overview of which public resources have been available, and how the funds were used. Some ministries do not always know what other ministries have done, so for this reason alone a better overview should be created.

\section{Management Resources}

In the beginning of the project the idea was followed that it was possible to calculate the number of people in central agencies working with grants, etc., in each country. It has proved relatively difficult to obtain material thereof. In a few programs the administration's stated size is announced, but otherwise it's not something that interests many. However, one of the most important factors to create success in this area is 
availability of sufficient manpower resources. Without this premise, it is almost impossible to lift an area, especially in a development phase.

This applies not only to grant funds, but also to administrative procedures and political support, writing strategies and reports. This is often forgotten by the authorizing authority, and, moreover, many institutions, as they are economically tightly controlled, have extreme difficulties to get degrees of freedom to solve the tasks. It is said in business that innovation must have good conditions, must be free to play and have plenty of time otherwise not very much might come out of it. This will also hold for activities of eco-efficient technology or environmental technology, which is relatively new and difficult to handle in a development phase. And this fact also holds for administrative aspects. There are generally too few resources and often too few experienced manpower resources for the area to get the best attention. There are even often focus on short-time aspects and political signaling, rather than long-term and fundamental work. The proof is not immediately present, but based on experience of how difficult it is to get enough good manpower resources.

An example that can be mentioned in this context is the demand side. The demand side is recognized by all countries as very important, but a question may be asked: which country have provided more manpower resources for the implementation of a strategy backing the demand side? Probably no country.

The recommendation must be based on this: make sure to allocate sufficient manpower resources both for managing grant programs and stimulating the demand side. With sufficient manpower resources meaning more than basically would have been allocated or abundant relative to normal.

\section{Strategies and action plans}

The Nordic countries are very good at formulating strategies or action plans. Recently we have seen strategies from Norway, Sweden, Iceland and to some extent Finland. These strategies were quite good and more focused than the previous versions, which were seen in the beginning of the period 2004-2011. What is difficult by the strategies are to implement the tasks or details in a good way, and to communicate this ongoing to the public and interested players.

The recommendation here is that there should be a better focus on implementation and dissemination of results etc.

\section{Example Strategies and Websites}

All Nordic countries have presented examples of eco-efficient technology or environmental technology to the public. This has been done best in Sweden, primarily through Swentec's work with a sample collection of 143 projects that also can be used as a visitors guide.

A description of the examples of technologies is the first step to get a better understanding. It is not difficult to make such individual cases that illustrate what is meant by good examples. On the whole it's a great 
idea to make a larger sample collection, preferably in English which can be used for international marketing.

It is recommended that each country makes available online descriptions of examples of promising technologies. It may also refer to the geographic location of a demonstration plant.

It is furthermore important to have good websites with description of what is happening in the country on the topic. One such website can also be developed with reports, references, tables, etc., and may almost be said to be indispensable. Experience from this project is that all countries should make better websites on eco-efficient technology or environmental technology. It is recommended that each country uses more resources to create better websites in that way.

\section{Venture capital}

Companies in development often have a need to attract active investment capital. In each of the Nordic countries there are public owned funds with venture capital, which invest in promising companies or technologies. Private venture capital also has an interest in such direct investments.

The project has not studied the market for venture capital in the individual Nordic countries. There are comments on the subject in many publications, and venture capital funds, especially public, also frequently publishes, what they have invested in. The reason for this lack of study in this project is that one can argue that venture capital is a special area which should have its own focus or may have its own focus.

It is recommended though that countries ensure that there is sufficient venture capital, when companies or businesses are looking for external capital supply.

\section{Demand side}

All Nordic countries are well aware that government policies have a great impact on the demand of eco-efficient technology or environmental technology. This is evident in reports, not least the new strategies, for example in Norway and Sweden. The state has by regulation a very good opportunity to influence the market. This is acknowledged. There is a big leap from this realisation to a more active working with market demandoriented instruments. The Nordic countries are in this project asked about measures to influence the demand side, both generally and in more specific cases. All responses are very general and not very concrete. It is obvious that the countries do not often work very concrete with the impact of demand in promoting eco-efficient technology.

Denmark has produced a publication about the environmental consequences of increased green public procurement. This report shows that only relatively small environmental performance can be achieved by using an increased share of government purchases by green procurement. The reason is probably that in green public procurement you 
must choose between products that are allowed and therefore the potential for environmental improvement is not quite as large as would be expected.

Sweden is the Nordic country that has done most work on environmental targets or environmental quality targets. In this field the other Nordic countries can learn much in their target setting and implementation thereof. It seems very positive, that this work continues to be developed in Sweden.

All Nordic countries have worked quite much with green public procurement. Much has been written on this topic and it is discussed how more can be done so that the proportion of green public procurement can increase. However, it is always used as a voluntary instrument. There has been no real attempt to use mandatory or binding request for actions, primarily because the economy has a very high priority and it is not permitted for financial reasons to demand that the government must buy green products with a clear preference. It is relevant to assess green public procurement or tenders in terms of environmental effects and at the same time to lower the expectations for what is achievable with a bigger effort. Sweden has done most in this area and should come with recommendations to the other Nordic countries about what exactly they can do more or better.

A special form of green public procurement is called supply of technology or provision of innovation. This is an area that is in development. This model is certainly probably best to highly targeted projects solving individual tasks, for example ferries, and not mass produced goods.

In Finland a publication on the regulation's impact on environmental innovations has been written. The publication is unfortunately only in Finnish, which means that other Nordic countries can not take advantage of this work and learn from it. The publication should be translated into Swedish or English and shared with other interested parties. All the Nordic countries ought to think through regulation and demand more systematically.

It is recommended that all countries should draft a report on how the government or the state may affect the demand side and establish procedures on how to improve it. The focus has to be both on general instruments, such as financial charges, but also on very specific examples, such as NOx, where regulation and charges in combination have shown good results. Such a report should also consider concrete procedures by the government administration to influence demand.

\section{The role of environment ministries}

Eco-efficient technology or environmental technology is truly an environmental agenda, although it often takes the form of a business agenda. It seems that the environmental angle is often neglected in many contexts. Ministries of environment usually appear as the weak part in the work and have undoubtedly the most difficult area, namely regulation 
and to a less degree grant administration, which must be considered an easier area. Charges or taxes are often the responsibility of the economic ministries. Environment ministries are in some cases responsible for grant funds, although this is the exception rather than the rule. In Sweden and Denmark the environment ministries or Naturvårdverket and Miljøstyrelsen hold grant funds and therefore seem to be in a better position to act. Environment Ministries should be closely involved in decisions about grants, since it is an environmental area and the influence of demand is often located within the environmental ministries.

An area that environment ministries should take more serious is the environmental assessment of technology. There are too many degrees of freedom or weaknesses in the way environmental assessment of technology are conducted in different countries. Usually there are no clear guidelines or publications thereof. Especially in situations where administration of grants are spread over a number of players it can be difficult to find the most valuable projects from the environmental viewpoints.

Energy ministries and energy authorities seem to be more fortunate, because they often have both grant funds and regulatory responsibilities. It gives some advantages to having a good opportunity to affect both sets of instruments.

It is recommended that the ministries of environment should work more with the impact of demand and also with assessments of technology and what technologies are best seen from an environmental point of view.

\section{Evaluations}

Despite the fact that eco-efficient technology is a very important area for government announcements, evaluations of the area or topics are not often seen. This is probably primarily due to the fact that efforts have only lasted for a few years. Only two real evaluations are found and a number of evaluations are underway.

It is highly recommended that the entire action or parts thereof are evaluated in each country in addition to the evaluations of the concrete grant programs. Without independent evaluations the legitimacy of actions seems to be undermined.

\section{Green growth or green economy}

Green growth or green economy will to some extent take over the agenda in most countries. It is more interesting than the somewhat more technical eco-efficient technology or environmental technology. Green growth is the more direct business approach which seeks to boost growth through green initiatives or regulations, while the green economy is said to be the more prudent structuring of the economy by turning the focus toward more environmentally correct or sensible solutions. Should green growth and green economy succeed in a fundamental way, it will require changes to a number of community structures in a very radical way. It will also cost considerable sums in the startup phase, 
although there are many indications that it will be just as cheap, maybe even cheaper for the economy in the longer term, especially if the environmental costs or expenses, i.e. externalities, are fully recognized.

To get the full effect of green growth and green economy a significant amount of factors must be changed, not least the prices, by for example charges. It appears already that there are significant benefits to the economies that have already succeeded in introducing green taxes to some extent and can live with this in competition with other economies that have done nothing yet. However, it is also clear that there is much more to be gained by increasing this effort.

Eventually many countries will follow their own strategies for green growth and green economy such as Iceland is about to do. This allows such countries to take a step forward if they ensure an effective implementation. A recommendation to the Nordic countries must be to develop such national strategies for green growth and green economy and ensure its effective implementation.

Eco-efficient technology or environmental technology is a prerequisite for green growth or a subset thereof. Without a strong development in this area, it will be almost impossible to create a prudent green growth and green economy. Therefore, the countries need to formulate sound and strong strategies for eco-efficient technology or environmental technology, if they focus on green growth and green economy.

\section{The Nordic cooperation}

The Nordic cooperation has already made a number of activities to promote eco-efficient technology or environmental technology. This can be done better in the future, especially if the Nordic countries are helped to do what they do best. Initially in the countries' own interest, but then also to show the other Nordic countries how it can be done, and also, to show the same to countries outside of The Nordic area.

\subsection{Recommendations}

All recommendations must be seen as an attempt to strengthen the Nordic countries' efforts for eco-efficient technology or environmental technology. If a country declares that it wants to have a high profile in the area or encourage development and innovation in the field, there should be an interest to follow the recommendations. A country should conduct an assessment of whether and how they want to follow a recommendation.

\section{Common recommendations}

- It is recommended to use eco-efficient technology or environmental technology as a concept compared to other concepts, and that climate and energy are declared an implemented as an integrated part in this concept 
- Provision should be made for an annual statistics of companies in each country. The statistics should try to determine the number of companies, employment and turnover, and use a breakdown of areas, such as suggested above. Environmental weighting of large enterprises should be used and should be conducted with a certain company size, for example 5 employees as a minimum. A government department should have an ultimate responsibility for the statistics

- Exports from the sector should be measured every year to indicate how the sector is doing internationally. A governmental authority should also be responsible for export statistics

- The Nordic countries should make periodic reports on the number of patents taken out in each country, to get an understanding of innovation power

- Each country should maintain a good overview of how much funding is available each year and what the funds have been used for

- There should be more requirements to the grant administrator for information and dissemination of particular outcomes

- Make sure there are sufficient manpower resources available for management of grant programs, monitoring, analysis etc.

- Countries must ensure that there are sufficient grant funds and venture capital to meet the reasonable needs of companies

- Countries must take a more systematic approach to support the demand side, especially with regulation. Green public procurement should be considered to be made more mandatory or binding

- There should be evaluations more frequently than is currently the case

- A good coordination of a country's effort among various state actors should be ensured, not least between grant administrators and regulators, if these items are separated

- Environment ministries should be integrated into the work and should focus on influencing the demand side and details of environmental assessments of technology

- Each country should develop better example strategies and websites, making it easier to monitor developments

- The Nordic countries should cooperate more internationally, not least in relation to an EU agenda

- Not least in order to strengthen eco-efficient technology each country should produce a strategy for green growth and green economy, and implement this effectively

\section{Recommendations for individual countries}

To stimulate interest of individual countries are below highlighted a key recommendation for the country. It focuses on the action plan and strategies, but such a strategy or action plan can as a help be very short such as in Sweden. 


\section{Denmark}

Denmark should, like the other Nordic countries, develop one or more strategies, since the ones developed are getting outdated. The climate/energy side should make a brief, clear plan of action when a new climate/energy compromise is in place. This action plan should focus on the link between grant funds, regulations and targets. The environment side should also develop a new plan, preferably including MUDP, GUDP and Fornyelsesfonden thereby increasing the overall impact of environmental initiatives.

\section{Finland}

The Finnish government should also, after a number of invitations, prepare a new action plan to give environmental technologies in Finland more weight. This action plan should be short and clear and should relate to the many concepts of environmental technology, green growth, bio-economy, natural resources etc.

\section{Iceland}

Iceland should of course implement the recommendations in the report on the green economy. And Iceland should furthermore prepare a more detailed action plan for environmental technology, which also can be seen in a long-term perspective.

\section{Norway}

Norway has already prepared a new strategy or action plan. This should be implemented in the best way and one should have a focus on the implementation of the recommendations, not least to have a better match between political statements and use of instruments, for instance grants or regulations etc.

\section{Sweden}

Sweden has also recently published a new strategy or action plan. This should be implemented according to recommendations. One should be careful not to lose the momentum Swentec created by its targeted efforts.

\section{Recommendations for individual countries in a cooperative spirit}

It often appears that everyone is in favour of more cooperation, but when it must be performed no one has the resources or the time for it. Therefore only one or a few specific recommendations are proposed. And these proposals are also understood as a form of self-help to the countries. Each country has done something unique and can promote this. Obviously, it would cost little to implement it, but there will certainly be considerable international interest, not only Nordic interest in this, and there will also be the interest from the actors in the country itself. The recommendation can be implemented typically with a publication. It should have an educa- 
tional angle, but also hopefully a slightly more honest approach than is generally seen in publications promoting a country.

These recommendations, as described below may be discussed at a joint seminar.

\section{Denmark}

It is proposed that Denmark, when the new climate/energy compromise is in place, could prepare a publication on what has been done and how to approach the phase-out of greenhouse gases. Denmark could also draft a publication about eco-efficient technology in the agricultural sector, since Denmark clearly has done quite a lot in this area, but still has tasks to do.

\section{Finland}

Finland has done a lot on demand and regulation and may, by translation of the material for example into English, start a good discussion. Finland can also be the leader for user-driven innovation that is well developed in Finland.

\section{Iceland}

Iceland should tell about its road to a green economy. And Iceland can as well tell about the great opportunity in the use of geothermal energy and the future prospects for this.

\section{Norway}

Norway has unique experience in CCS, carbon capture and storage at sea and should tell about the experiences in using this technology. Norway has also a high efficiency in reducing the use of energy in the field of industry compared to other Nordic countries and this could be described.

\section{Sweden}

Sweden is ahead in several areas. One should make a detailed publication about sustainable cities, showing how far you can reach in a single country. Sweden could also promote the country by telling about what has been done for green public procurement, as it seems clear that Sweden is a leader among the Nordic countries in that area. 


\section{Miljøeffektiv teknologi eller miljøteknologi i de nordiske lande}

I rapporten beskrives de nordiske landes aktiviteter indenfor miljøeffektiv teknologi eller miljøteknologi i perioden 2004-11. Rapporten dokumenterer, at samtlige nordiske lande har store ambitioner på området, men der er samtidig et stort behov for større viden i hvert af de nordiske lande om virksomheder, eksport, patenter, enkelte projekter, overblik etc. Rapporten dokumenterer også, at der er et endog meget stort behov for at fremme efterspørgselssiden, eftersom ingen af landene gør nogen målrettet indsats på dette felt.

Hvert af de nordiske lande beskrives i et afsnit med vægten på den sidste del af perioden, og der gives anbefalinger til forbedringer. Der sker en vis sammenligning landene imellem, og der gives anbefalinger til, hvordan hvert enkelt land kan bidrage til en forbedret indsats, som måske også kan hjælpe de andre lande. Denne gennemgang af landene er rapportens hovedindsats. Hertil er der et indledningsafsnit, som sætter undersøgelsen i perspektiv og en sammenfatning, som forsøger at give anbefalinger til en forbedret indsats. Det anbefales generelt, at der etableres bedre datagrundlag om virksomheder og eksport etc. Det anbefales også, at der tilvejebringes mere information og bruges flere mandskabsressourcer. Og endelig anbefales det, at der gøres langt mere ved at styrke efterspørgselssiden i arbejdet med miljøeffektiv teknologi. 